PNL-7109

UC-350

Revision of the Energy

Conservation Requirements

in the Manufactured Home

Construction and Safety Standards

C. C. Conner

A. D. Lee

R. G. Lucas

Z. T. Taylor

February 1992

Prepared for the U.S. Department

of Housing and Urban Development under a Related Services Agreement with the U.S. Department of Energy Contract DE-AC06-76RLO 1830

Pacific Northwest Laboratory Operated for the U.S. Department of Energy by Battelle Memorial Institute 


\title{
DISCLAIMER
}

This report was prepared as an account of work sponsored by an agency of the United States Government. Neither the United States Government nor any agency thereof, nor Battelle Memorial Institute, nor any of their employees, makes any warranty, expressed or implied, or assumes any legal liability or responsibility for the accuracy, completeness, or usefulness of any information, apparatus, product, or process disclosed, or represents that its use would not infringe privately owned rights. Reference herein to any specific commercial product, process, or service by trade name, trademark, manufacturer, or otherwise does nol necessarily constitute or imply its endorsement, recommendation, or favoring by the United States Government or any agency thereof, or Battelle Memorial Institute. The views and apinions of authors expressed herein do not necessarily state or reflect those of the United States Government or any agency thereof.

\author{
PACIFIC NORTHWEST LABORATORY \\ operated by \\ BATTELLE MEMORIAL INSTITUTE \\ for the \\ UNITED STATES DEPARTMENT OF ENERGY \\ under Contract DE-ACO6-76RLO 1830
}

Printed in the United States of America

Ayailable to DOE and DOE contractors from the

Office of Scientific and Technical Information, P.O. Box 62, Oak Ridge, TN 37831; prices available from (615) 576-840t. FTS 626-8401.

Available to the public from the National Technical Information Service, U.S. Department of Commerce, 5285 Port Royal Rd., Springfieid, VA 22167. 
PNL -7109

UC -350

\section{REVISION OF THE ENERGY CONSERVATION REQUIREMENTS IN THE MANUFACTURED HOME CONSTRUCTION AND SAFETY STANDARDS}

C. C. Conner

A. D. Lee

R. G. Lucas

Z. T. Taylor

February 1992

Prepared for

the U.S. Department of Housing and Urban Development under a Related Services Agreement with the U.S. Department of Energy Contract DE-AC06-76RLO 1830 


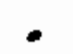

- 


\section{ABSTRACT}

Thermal requirements were developed for manufactured (mobile) homes in response to legislation requiring the U.S. Department of Housing and Urban Development (HUD) to revise its thermal standards for manufactured homes. A life-cycle cost minimization from the home owner's perspective was used to establish an optimum in a large number of cities for several prototype homes. The development of the economic, financial, and energy conservation measure parameters input into the life-cycle cost analysis was documented. The optimization results were aggregated to zones which were expressed as a maximum overall home U-value (thermal transmittance) requirement. The revised standard's costs, benefits, and net value to the consumer were quantified. 
- 


\section{SUMMARY}

Congress passed legislation that requires the U.S. Department of Housing and Urban Development (HUD) to revise energy conservation standards for manufactured housing. The HUD contracted with the Pacific Northwest Laboratory (PNL) to assist in developing a revision to the energy conservation requirement in the HUD's existing Manufactured Home Construction and Safety Standards (MHCSS).

The approach used in developing the proposed standard revision was specified as a cost-benefit analysis in which the costs of energy conservation measures (ECM) were balanced against the benefits of energy savings. The resulting optimum was used to specify an overall level of energy conservation in terms of a building shell U-value (thermal transmittance) that ensured the lowest total of construction and operating costs to the owner of a manufactured home. (HUD's current thermal standard is also a U-value based standard.) This report documents development of the revised standard.

Several major activities were required to develop the revised standard. A life-cycle cost model was required to determine the optimum ECM investment. ECM options, including each ECM's cost and U-value, was required as input. The optimization required definition of the financial, economic, and fuel price parameters used in the life-cycle cost analysis. Initially, separate Uvalue optimums were defined for a large number of U.S. cities for single- and double-wide homes with different fuels. In a multi-step process, these separate $U$-values were aggregated into four national U-value zones. First, values for single- and double-wide, the different fuels, and individual cities were aggregated to the state level. Then the states were grouped into zones based on similarity in U-value. Each U-value zone was made up of one or more states with a specific maximum $U$-value requirement. The resulting revised $U$ values are significantly tighter than the current standard.

Congress specified a life-cycle cost (LCC) analysis from the consumer's perspective as the basis for revising the HUD thermal standard. A life-cycle cost analysis compares the total long-run (present value) dollar costs for several alternative courses of action and selects the course of action that achieves the objective for the least cost. For this LCC analys is the benefit 
is the energy savings from the ECMs; the major cost is the ECM cost, including the associated mortgages, fees, and payments.

The analysis to develop the standard was done with the Automated Residential Energy Standard (ARES) software. The ARES was developed by the U.S. Department of Energy (OOE) specifically for the development of residential energy conservation standards. The ARES implements a life-cycle cost methodology for residential energy conservation decisions. Besides a life-cycle cost model, ARES incorporates an energy simulation model thereby allowing ARES to project energy costs for a range of alternative ECMs. Given a set of fuel price, financial, economic, and ECM costs for a building at a specific location, ARES identifies the set of ECMs to invest in, such that the homeowner's total life-cycle cost is minimized.

Several financial, economic, and fuel price parameters were required for the LCC analysis. The principal legislative requirements affecting the selection of these parameters were the specifications that costs and benefits be calculated from the owner of a manufactured home's perspective, and that the physical lifetime of the structure be used as the analysis period. Because most homes are purchased with financing, the development of the standard was based on a manufactured home purchased with financing. The loan selected had a $14 \%$ mortgage rate over 14 years with a down payment of $15 \%$ The nominal discount rate was $12 \%$ ( $7 \%$ real). The inflation rate was $4.9 \%$. The period of analysis and building lifetime were both 33 years. Each state's average residential fuel prices were defined for electricity, fuel oil, natural gas, and liquid petroleum gas (LPG). Residential fuel price escalation rates were defined by U.S. census region. Nationally, these annual fuel escalation rates (real) averaged: electricity, $0.0 \%$ (constant); fuel oil, 2.5\%; natural gas, $2.0 \%$; and LPG, $2.3 \%$.

The ECMs selected represent the conservation investment choices used in a life-cycle cost analysis to determine the consumers's optimum level of investment in energy conservation. For each type of $\operatorname{ECM}$ (e.g., wall insulation), lists of candidate options, costs, and thermal characteristics were developed. The selection of candidate ECMs and each ECM's cost was based on surveys of about one-third of the manufacturing plants in the U.S. 
TABLE S.1. Range of Insulation Values Selected

\begin{tabular}{cc} 
Building Component & \multicolumn{2}{r}{ Range of Options } \\
\cline { 2 - 3 } Ceiling & $R-11$ to $R-38$ \\
Wall & $R-7$ to R-19 \\
Floor & $R-7$ to R-22
\end{tabular}

Only ECMs determined to be available in commercially produced homes were included as candidate options. As directed by congress, single- and doublewide homes were considered separately when there were significant differences between the ECM characteristics of the two. The ranges of insulation levels included as options are shown in Table S.1. ECM descriptions and costs were also developed for windows and doors.

Energy Conservation Measures that would lower infiltration were considered, but rejected based on several concerns. Currently new manufactured homes are relatively airtight, so very low natural infiltration rates would result from further tightening. In the absence of ventilation, very low infiltration rates can have significant negative impacts on occupant health. The recommendation of ventilation standards to mitigate health effects of very low levels of infiltration is difficult based on the current state-ofthe-art, and would require further study. There were also practical concerns with measuring infiltration rates and assigning responsibility in the event of noncompliance. For these reasons no infiltration control ECMs were considered. Thus no changes in the HUD's current requirement for infiltration control options were specified.

Heating and cooling equipment efficiencies are required for 1 ife-cycle cost analysis. The National Appliance Energy Conservation Act 1987 (NAECA) minimum standards for heating and cooling system efficiency in manufactured homes were assumed. A procedure to give credit for efficiencies higher than those required by NAECA was also developed.

Initially, single- and double-wide homes that made use of five specific types of heating, ventilation and air conditioning (HVAC) equipment and fuels were optimized by ARES. The five equipment/fuel types for which optimum Uvalues were produced for each city were: 
- natural gas with a forced air furnace

- LPG with a forced air furnace

- oil with a forced air furnace

- electric resistance with a forced air furnace

- electric heat pump with forced air distribution.

In all cases an electric air-conditioning system was included. The two manufactured home prototypes, which were optimized separately, were

- single-wide home

- double-wide home.

Rather than selecting a few cities to represent the U.S, all 881 cities available in ARES were used. Selection of all 881 cities included in ARES provided a density of locations such that any point in the U.S. was close to a city for which an optimum U-value was produced. This coverage alleviated any bias that might have resulted from selecting a small number of cities to encompass the large area of the country.

After the production of the $8,810 \mathrm{U}$-values (881 cities for five HVAC/fuel types for both single- and double-wides), the individual U-values were aggregated to $\mathrm{U}$-value zones in four steps:

- Individual city U-values were extrapolated into state U-values.

- Single-wide and double-wide U-values were determined to be very similar and were combined into U-values for all homes.

- The separate HVAC equipment and fuel types were aggregated into U-values for all equipment/fuel types based on the frequency with which each type of equipment was present in each region. Consideration was given to establishing separate fossil fuel and electric U-values, but the combination of all system types was selected as preferable for a number of reasons, including simplicity.

- A mathematical technique was used to group states with similar U-values into the $\mathrm{U}$-value zones required by Congress. Four zones were selected as representing the range of U-value optimums found in the U.S. The Uvalue applicable to each zone was defined as the sales weighted average of the U-values for all states in that zone. The four zones and the Uvalue requirement associated with each is shown in Figure S.1. 


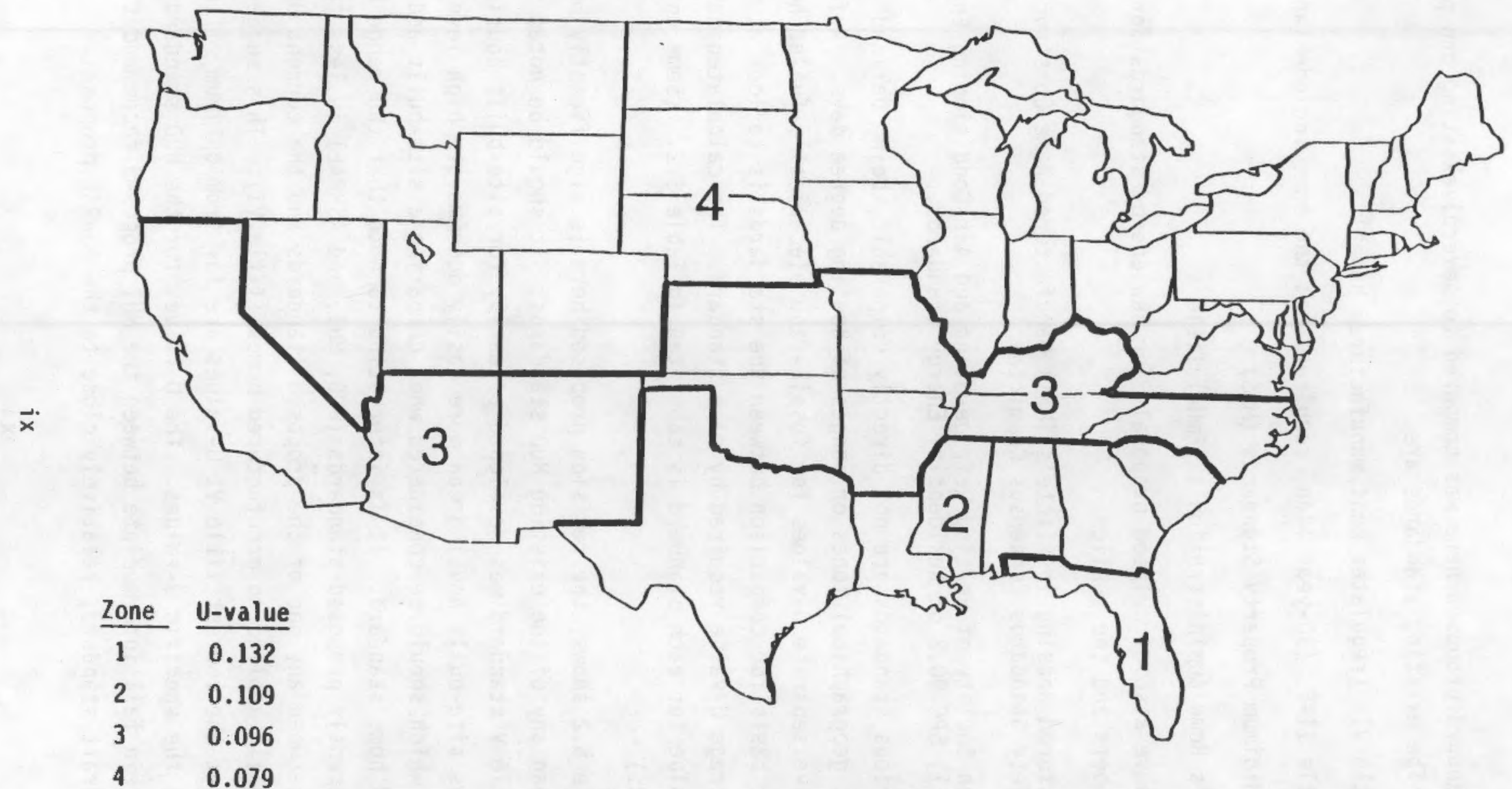

FIGURE S.1. U-value Zones(a)

(a) Hawaii is zone 1. Alaska is zone 4. 
The standard proposed here was compared to several existing and proposed standards. The existing standards are

- HUD Title VI (regulates most manufactured homes)

- HUD Title II-E (30-year loan, requires that the home include land)

- HUD's Minimum Property Standards (MPS)

- Farmer's Home Administration's (FmHA) Title V.

Two groups have also circulated proposals for new energy standards for comment by their members and the public

- Manufactured Housing Institute's (MHI) Manufactured Home Construction and Safety Standards Consensus Committee

- American Society of Heating Refrigerating and Air-Conditioning Engineers (ASHRAE), SPC 90.2 on Residential Energy Standards.

The various standards are not directly comparable, being defined in terms of different geographical zones or ranges of heating degree days. A few standards have separate U-values for fossil- and electrically-fueled homes. The simplest basis for comparison between the standards is to look at the national average $U$-value required by each standard. The calculated national average U-value for each standard is tabulated in Table S.2. (Some cases are approximated.)

As Table S.2 shows, the revision proposed here is significantly more stringent than any of the existing HUD standards. It should be noted that the FmHA Title $V$ standard was developed primarily for site-built housing. In some cases site-built housing can more easily accommodate high levels of insulation, which should be considered when comparing a site-built and manufactured home standard. It is interesting to note that the range between the three recently proposed standards (HUD, MHI, and ASHRAE) is less than the difference between any one of the proposed standards and the current HUD standard usually applied to manufactured homes (Title VI). This suggests a consensus that the current Title VI U-values are far from optimum, if not a consensus on the specific U-values. The U-values for the HUD standard proposed herein fall intermediate between the MHI proposed recommendation and the ASHRAE draft standard, relatively close to the ASHRAE proposal. 
TABLE S.2. Average National U-value for Selected Standards

$\begin{array}{cll}\frac{\text { Average U-value }}{0.145} & & \text { HUD Title VI } \\ 0.125 \text { to } 0.140 & & \text { Estimated current practice } \\ 0.125 \text { to } 0.135 & & \text { HUD Minimum Property Standards (a) } \\ 0.127 & \text { HUD Title II-E } \\ 0.111 & \text { MHI MHCSS Consensus Committee } \\ 0.098 & & \text { Revision proposed herein } \\ 0.090 \text { to } 0.095 & \text { FmHA Title V(a) } \\ 0.092 & \text { ASHRAE 90.2P, Residential Standards }\end{array}$

(a) MPS and FmHA use a significantly different U-value calculation methodology, primarily by not including framing in the U-value. The U-values shown here approximate the $U$-value if framing was included. It should also be noted that the MPS and FmHA are for site-built homes, not manufactured homes.

The costs and benefits from the consumer's perspective were calculated for three cases. These cases were: 1) the estimated current practice, 2) the existing HUD Title VI standard, and 3) the proposed standard from this report.

The proposed standard was compared to the estimated current practice for new manufactured homes. The average current practice U-value is lower than the HUD maximum because a significant number of homes have insulation values at least somewhat above that required to meet the HUD maximum U-value. The proposed standard was estimated to increase costs by about $\$ 800$ to $\$ 1100$ per home above current practice, with an energy savings usually 2 to 2.5 times the cost.

The proposed standard was compared to the Title VI minimum requirement. The present value of the net savings (energy savings minus costs) from the proposed standard exceeded the present value of the Title VI standard by an average of about $\$ 2000$ per home. The cost increase above Title VI averaged about $\$ 1200$ per home. The value of the energy savings was approximately $\$ 3200$ per home. On a monthly basis these translate to an increase in the mortgage payment of $\$ 10 /$ month per home, which would continue for the 14 year life of 
the loan. The first year reduction in energy costs averaged \$18/month, which would slowly increase for the life of the home.

The aggregate national net value (costs minus benefits) of the proposed standard above the current practice was estimated. The net savings for the homes built each year would be about $\$ 20 \mathrm{M} /$ year, continuing for the lifetime of the homes. The total national savings would be about $\$ 20 M$ in the first year, $\$ 40 \mathrm{M}$ in the second year ( $\$ 20 \mathrm{M}$ from the first year's homes plus $\$ 20 \mathrm{M}$ from the second year's homes), $\$ 60 \mathrm{M}$ in the third year, and so on. Yearly national savings would continue to increase as energy-efficient manufactured homes became a higher fraction of the housing stock. The aggregate present value of the savings for each year in which the proposed standard is in effect would be about $\$ 300$ million when compared to current practice. (The present value would be about $\$ 400$ million per year, if compared to the existing standard.)

The proposed standard also has a number of positive social impacts including a reduction in the environmental impacts of energy use. These benefits result from impacts of the standard that are external to the market valuation of energy use. The environmental impacts include a reduction in the emission of $\mathrm{SO}_{2}, \mathrm{NO}_{\mathrm{x}}$, and particulates during the generation of electricity and the burning of fossil fuels. The emission of $\mathrm{SO}_{2}, \mathrm{NO}_{x}$, and particulates is estimated to have a present value of $\$ 50$ million to $\$ 160$ million per year.

Two alternative methods of compliance are suggested for inclusion in the standard, both are defined in the body of this report. The first alternative method allows a trade-off between investments that lower a home's U-value and investments in high efficiency HVAC equipment. This alternative gives homes a U-value credit for increases in HVAC efficiency, but does not require the use of equipment above the NAECA standard. The second alternative allows a calculation or simulation of annual energy use to show that a home meets the energy use implicit in the U-value standard.

Based on the contents of this report, a revised text of HUD's manufactured home thermal standard has been recommended to HUD. 


\section{ACKNOWLEDGEMENTS}

The author is indebted to William Freeborne and Donald Faiman of HUD for their guidance and support in producing this work. Mr. Freeborne's technical reviews were instrumental in assuring the quality of the standard proposed herein.

A number of individuals contributed to this work. Essential technical reviews and guiding comments were provided by Jean Boulin of the Department of Energy, Thomas Ekman of the Northwest Power Planning Council, Merle McBride of Owens-Corning Fiberglass, and Vincent Wanzek of Fleetwood Enterprises. The expertise and insight of David Conover, formerly of the National Conference of States on Buildings Codes and Standards, was greatly appreciated. Anthony Karwoski, fornerly of the Manufactured Housing Institute, provide helpful comments and background infomation. Acknowledgement of these individuals is an expression of appreciation by the authors, and does not imply their agreement with this report or its conclusions. 
, 


\section{CONTENTS}

ABSTRACT ...........................

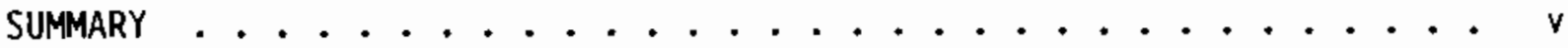

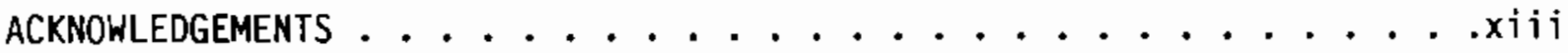

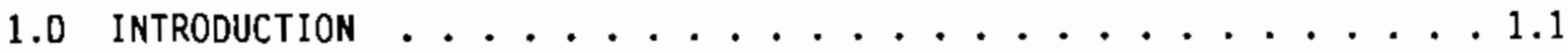

2.0 LIFE-CYCLE COST MODEL . . . . . . . . . . . . 2.1

2.1 Legislative REQUIREMENTS PERTAINING TO OPTIMIZATION $\ldots \ldots$.

2.2 LIFE-CYCLE COST ANALYSIS . . . . . . . . . . . . 2.1

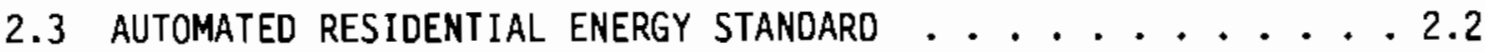

3.0 FINANCIAL, ECONOMIC, AND FUEL PRICE PARAMETERS ......... 3.1

3.1 Legislative REQUiREMENTS PERTAining to PaRAMETER SELECTION • • 3.2

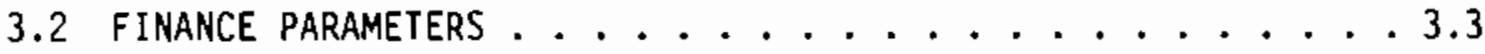

3.2.1 Mortgage Interest Rate ............... 3.3

3.2 .2 Loan Term . . . . . . . . . . . . 3.4

3.2 .3 Down Payment . . . . . . . . . . 3.4

3.2.4 Points and Loan Fees .............. 3.4

3.3 eCOnOMic Parameters . . . . . . . . . . . . 3.4

3.3.1 Discount Rate (A1ternative Investment Rate) . . . 3.5

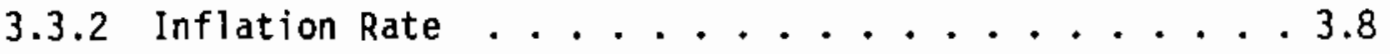

3.3.3 Period of Analysis and Building Lifetime . . . . 3.9

3.3.4 Property Tax Rate . . . . . . . . . . . 3.10

3.3.5 Income Tax Rate . . . . . . . . . . . . 3.10

3.4 FUel PRICE PARAMETERS . . . . . . . . . . . 3.10

3.4 .1 Fue1 Price Data . . . . . . . . . . . 3.11

3.4.2 Fuel Price Escalation Rates .......... . 3.11 
4.0 ENERgY CONSERVATION MEASURES . . . . . . . . . . . . . . 4.1

4.1 LEGISLATIVE REQUIREMENTS FOR

ENERGY CONSERVATION MEASURE SELECTION ............ 4.1

4.2 ENERGY CONSERVATION MEASURE CHARACTERISTICS REQUIRED . . . . 4.2

4.3 ENERGY CONSERVATION MEASURE DATA SOURCES . . . . . . 4.3

4.3.1 Manufacturer Surveys ............ 4.3

4.3.2 Window Data Survey . . . . . . . . . . 4.6

4.4 PROTOTYPE SINGLE- AND DOUBLE-WIDE HOMES $\ldots \ldots . \ldots . \ldots$

4.5 BASE AND TYPICAL ENERGY CONSERVATION MEASURE LEVELS . . . 4.7

4.6 ANALYSIS OF ENERGY CONSERVATION MEASURE COST

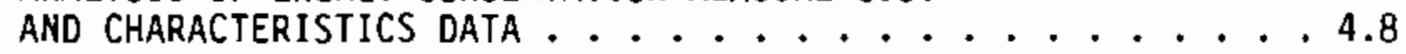

4.6.1 Energy Conservation Measure Cost Determination . . . 4.9

4.6.2 Determining Energy Conservation Measure Options . . . 4.10

4.6.3 Ceiling Energy Conservation Measures ....... 4.10

4.6.4 Wall Energy Conservation Measures ........ 4.11

4.6.5 Floor Energy Conservation Measures ....... 4.13

4.6.6 Window Energy Conservation Measures . . . . . . 4.15

4.6.7 Door Energy Conservation Measures ........ 4.17

4.6.8 HVAC Equipment Energy Conservation Measures . . . 4.18

4.6.9 Infiltration Energy Conservation Measures . . . . 4.20

4.6.10 Energy Conservation Measure Lifetime . . . . 4.23

4.7 RETAIL TO WHOLESALE COST MULTIPLIERS . . . . . . . 4.23

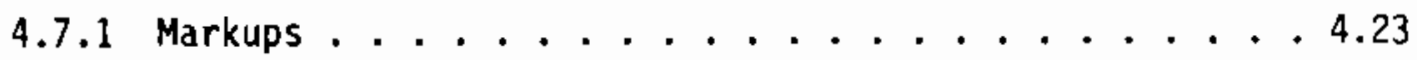

4.7.2 Regional Cost Multipliers ........... 4.24

4.8 DUCTS . . . . . . . . . . . . . . . . . . . . . . . 
5.0 OPTIMUM U-VALUES AND U-VALUE ZONES $\ldots \ldots . \ldots . \ldots . \ldots . \ldots$

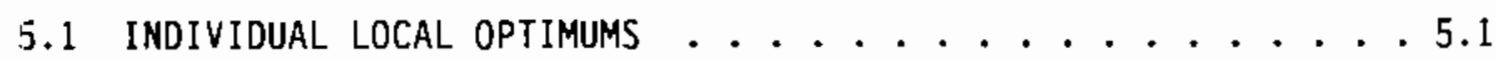

5.2 AgGREgATION FROM CITY TO STATE . . . . . . . . . . 5.3

5.3 AGGREGATION OF SINGLE-WIDE AND DOUBLE-WIDE PROTOTYPES $\ldots 5.4$

5.4 AgGREgATION ACROSS EQUIPMENT AND FUEL TYPES . . . . . . . 5.5

5.5 CREATION OF U-VALUE ZONES . . . . . . . . . . . 5.6

5.6 COMPARISON TO OTHER STANDARDS .................... 5.10

5.7 SENSITIVITY OF U-VALUES TO ASSUMPTIONS . . . . . . . 5.12

5.8 EXTENDED ECMS SENSITIVITY ANALYSIS . . . . . . . . . 5.15

5.9 DIFFERENCE BETWEEN CITY AND ZONE OPTIMUMS. . . . . . . 5.17

5.10 LIFE-CYCLE SAVINGS, MORTGAGE COSTS, AND ENERGY SAVINGS . . . 5.20

5.10.1 Comparison of the Proposed Standard

to Current Practice . . . . . . . . . . 5.20

5.10.2 Comparison of the Proposed Standard to the Title VI Standard. . . . . . . . . . . 5.21

5.10.3 Comparison of R-values for Proposed Standard and Title VI. . . . . . . . . . . . 5.25

5.10.4 Social Benefits of the Revised Standard . . . . . 5.25

6.0 alternative methods of compliance . . . . . . . . . 6.1

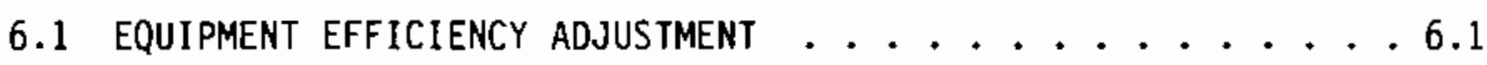

6.2 Calculation/Simulation alternative .............. 6.1

7.0 PROPOSED STANDARD TEXT $\ldots \ldots \ldots . \ldots \ldots \ldots$

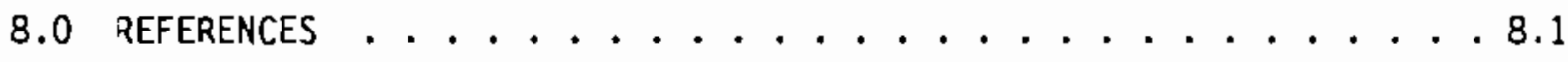

APPENDIX A - FUEL PRICES, EQUIPMENT/FUEL TYPES, AND DEGREE DAYS

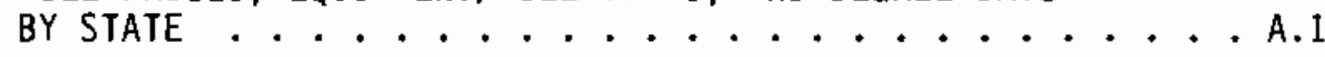

APPENOIX B - COMPONENT U-VALUES . . . . . . . . . . B.1

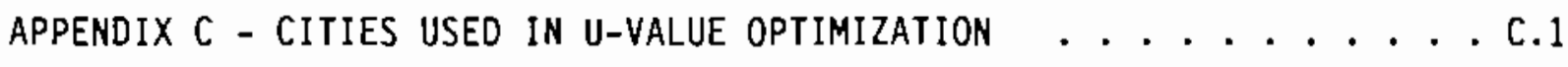

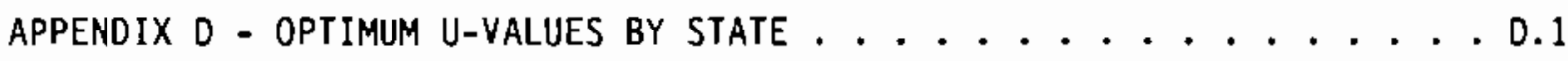


APPENDIX E - hOME SHIPMENTS BY STATE, 1984 ThROUGH 1988 . . . . . . . . E.1

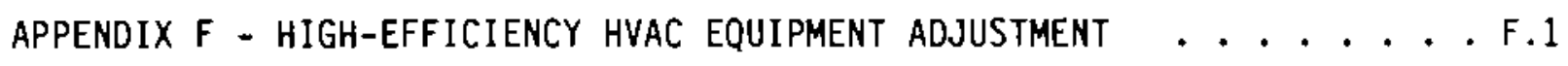
APPENDIX G - FAILURES IN THE MARKET FOR ENERGY EFFICIENCY. . . . . . . . G.l APPENDIX H - THE VALUE OF ENVIRONMENTAL EXTERNALITIES. . . . . . . . . . H.1 APPENDIX I - EXAMPLES OF COSTS AND BENEFITS . . . . . . . . . . . I. 1

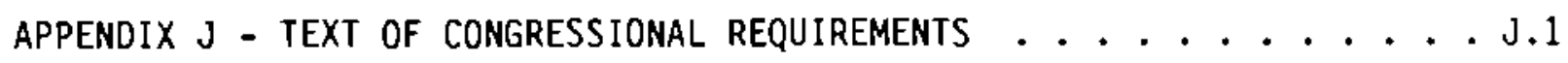




\section{$\underline{\text { FIGURES }}$}

S.1 U-value Zones................... ix

1.1 Major Standard Development Activities . . . . . . . . . 1.2

4.1 Manufacturing Plants Surveyed . . . . . . . . . . . 4.5

4.2 Total Number of Manufacturing Plants . . . . . . . . 4.5

5.1 Cities Used in U-value Optimizations . . . . . . . . . . 5.2

5.2 Optimum U-values by State . . . . . . . . . . . . 5.7

5.3 U-value Zones ...................... 5.9

5.4 Relationship Between Life-Cycle Cost and U-value for Jacksonville Florida . . . . . . . . . . . 5.18

5.5 Relationship Between Life-Cycle Cost and U-value for Washington D.C. . . . . . . . . . . . 5.18

5.6 Monthly Mortgage Payment Increase for Proposed Standard . . . . . 5.22

5.7 Present Value of Cost Increase for Proposed Standard . . . . . . 5.22

5.8 Monthly Energy Cost Decrease for the Proposed Standard . . . . . 5.23

5.9 Present Value of Energy Savings for Proposed Standard . . . . . 5.23

5.10 Life-Cycle Cost Savings (Net Savings) for Proposed Standard . . . 5.24

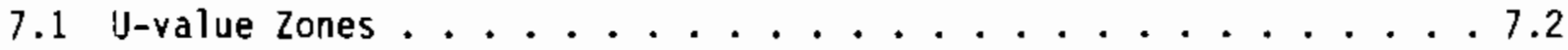

A.1 Electricity Prices, $\%$ Difference from National Average . . . . . . A.4

A.2 Natural Gas Prices, \% Difference from National Average . . . . A.4

A.3 LPG Prices, \% Difference from National Average . . . . . A.5

A.4 Fuel 0 il Prices, : Difference from National Average . . . . . A.5

A.5 Choice of fuel Type by Region . . . . . . . . . . A.7

A.6 Heating Degree Days, $\frac{0}{6}$ Difference From National Average . . . A. A 8

A.7 Cooling Degree Days, \% Difference From National Average .....A.8

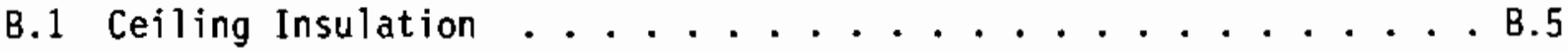

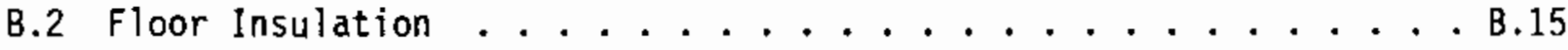




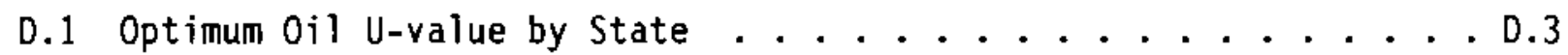

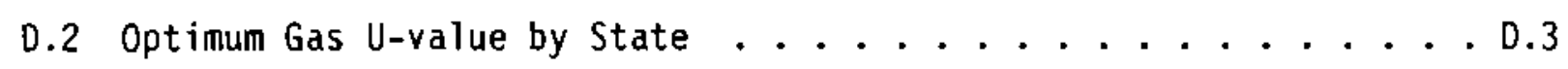

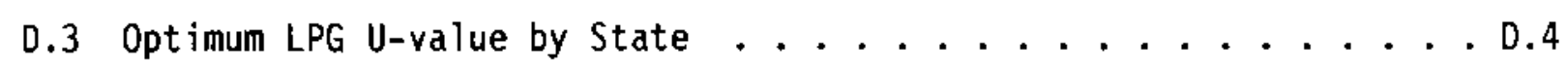

D.4 Optimum Electric U-value by State ............ . . . . . .

D.5 Optimum Heat Pump U-value by State . . . . . . . . D.5

D.6 Average Ceiling R-value by State .............. . . . .

D.7 Average Wall R-value by State ............. . . . . . .

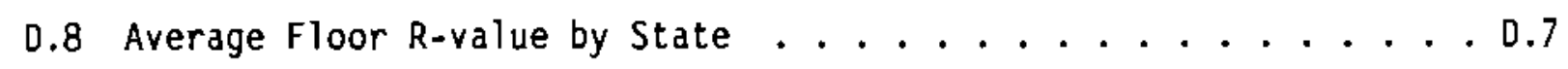

D.9 Average Window by State . . . . . . . . . . . . 0.7

E.1 Mean Home Shipments by State, 1984 through $1988 \ldots \ldots$. . . . E.3 


\section{$\underline{\text { TABLES }}$}

S.1 Range of Insulation Values Selected .............. . . i

S.2 Average National U-value for Selected Standards ......... xi

3.1 Reported Interest Rates . . . . . . . . . . . . 3.3

3.2 Value of $\$ 1$ per Year Savings . . . . . . . . . . 3.10

3.3 Resideritial Fuel Price Escalation Rates

for 1988 through 2021 by U.S. Census Region . . . . . . . . 3.12

4.1 Prototypical Home Characteristics . . . . . . . . . 4.7

4.2 Base and Typical Characteristics . . . . . . . . . . 4.8

4.3 Ceiling ECM Incremental Retail Cost Parameters . . . . . . . 4.11

4.4 Ceiling ECM Option Characteristics ............ . 4.12

4.5 Wall ECM Incremental Cost . . . . . . . . . . . 4.13

4.6 Wall ECM Option Characteristics . . . . . . . . . . . 4.14

4.7 Floor ECM Incremental Cost . . . . . . . . . . . . 4.14

4.8 Floor ECM Option Characteristics . . . . . . . . . 4.15

4.9 Window Incremental Retail Cost Parameters ..........4.16

4.10 Window ECM Option Characteristics ........... . 4.16

4.11 Door ECM Option Characteristics .............4.18

4.12 Equipment Efficiencies Used in Life-Cycle Cost Analysis . . . . 4.19

4.13 Energy Conservation Measure Lifetimes .......... . 4.23

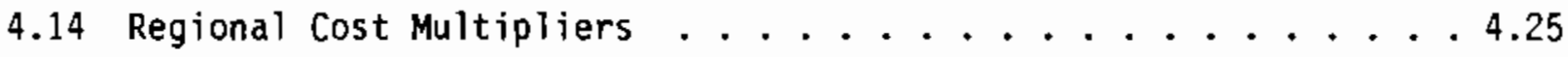

5.1 Fuel Types by Region ................ . . . 5.6

5.2 Average National U-value for Selected Standards . . . . . . . . 5.11

5.3 U-value Sensitivity to Selected Parameters ........ 5.13

5.4 Extended ECMs . . . . . . . . . . . . . 5.15

A.1 1988 Residential Fuel Prices by State ............... A. 
A.2 Nominal Fuel Escalation Rates, 1987 and 1988 . . . . . . . A.6

A.3 Seasonal Electricity Price Variation . . . . . . . . . . . A.6

B.1 Building Materials R-values . . . . . . . . . . . . . B.2

B.2 Insulation R-value at the Roof Edge . . . . . . . . . . . B.6

B.3 Ceiling U-values for Life-Cycle Cost Analysis . . . . . . . . B.7

B.4 Wall U-values for Life-cycle Cost Analysis . . . . . . . . . B.12

B.5 Floor U-values Used for the Life-Cycle Cost Analysis . . . . . B.16

B.6 Window U-values . . . . . . . . . . . . . . . . B.20

B.7 Door U-values . . . . . . . . . . . . . . . B.21

D.1 Optimum U-value by State . . . . . . . . . . . . . . 0.1

E.1 Mean Home Shipments by State, 1984 to 1988 . . . . . . . . . E.1

F.1 Assumptions for Derivation of UA/Degree-Day Relationship . . . . F.4

F.2 Uo Adjustments that Hold Energy Use Constant for Sample City . . F.6

F.3 Uo Adjustment Coefficients for Cooling . . . . . . . . . . . F.7

H.1 PACE Electricity Externalities . . . . . . . . . . . . H.3

H.2 BPA Fuel Specific Parameters . . . . . . . . . . . . . H.4

H.3 BPA Pollutant Externality . . . . . . . . . . . . . . . H.4

H.4 BPA Externality Cost by Pollutant . . . . . . . . . . . . . H.5

H.5 Total BPA Electricity Externality . . . . . . . . . . . . . H.5

H.6 Weighted Average Environmental Externality Based on BPA Values . . H.6

H.7 Estimated Environmental Costs from Energy Generation and Use . . . H.6

I.1 Summary of Costs from Consumer's and Social Perspective . . . . I.4

I.2 Incremental Changes in ECM and Energy Costs . . . . . . . . . I.5

I.3 Present Value Benefit from the Revised Standard in Dollars . . . . I.6

I.4 Consumer's and Social Costs for the Current Standard. . . . . . . I.7

I.5 Consumer's and Social Costs for Home Intermediate

Between Current and Revised Standard. . . . . . . . . . I.8 
I.6 Consumer's and Social Costs for the Revised Standard . . . . . I.9

\section{I.7 Consumer's and Social Costs for} Home Tighter than Revised Standard. . . . . . . . . . . . I.10 


\subsection{INTRODUCTION}

Congress passed the Housing and Community Development Act of 1987 (HCDA) requiring the U.S. Department of Housing and Urban Development (HUD) to revise energy conservation standards for manufactured housing (HCDA 1987; CRH 1987; CRS 1987; all are reproduced in Appendix $\mathrm{J}$ ). The HUD(a) brought the Pacific Northwest Laboratory (PNL) (b) (c) (d) under contract to assist in developing a revision to the energy conservation requirement in the HUD's existing Manufactured Home Construction and Safety Standards (MHCSS) (24 CFR 3280).

The approach PNL used in developing the proposed standard revision was a cost-benefit analysis in which the costs of energy conservation measures (ECMs) were balanced against the benefits of energy savings. The resulting optimum specified an overall level of energy conservation in terms of a building shell U-value (thermal transmittance) that ensured the lowest total of construction and operating costs to the owner of a manufactured home. This life-cycle cost optimization was performed for a large number of cities in the U.S. The resulting U-values were grouped into four zones with state boundaries, with each zone having a specific U-value requirement. This report documents the development of the revised standard.

Major activities in the development of the revised standard are illustrated in Figure 1.1. Chapters of this report are organized as follows. Chapter 2 presents a brief overview of the life-cycle cost model. Chapter 3 discusses the choice of the financial, economic, and fuel price parameters

(a) The HUD was represented by William Freeborne, Government Technical

Representative, Policy Research and Development; and by Donald R. Fairman, Chief, Standards and Products Branch, Manufactured Housing and Construction Standards Division, who served as Government Technical Monitor.

(b) Operated by Battelle Memorial Institute for the U.S. Department of Energy under Contract DE-AC06-76RLO 1830.

(c) The PNL project manager was Craig C. Conner.

(d) Most of this work was performed between mid-1988 and 1990 . Most of the following year (1991) elapsed during interactions with the office of Management and Budget, prior to release of the proposed standard for public comment by HUD. In the author's opinion, real fuel prices, energy conservation measure costs, and long-term projections of economic and financial parameters used in this report have not changed significantly since that time. 
used in the life-cycle cost analysis. Chapter 4 describes the energy conservation measures and their characteristics. Chapter 5 describes the creation of the optimum U-values for specific cities with various fuel types and HVAC (heating, ventilation and air-conditioning) equipment. Chapter 5 also describes the aggregation of the individual U-values into the U-value zones and compares the $U$-values from this proposed standard with the U-values of several other standards. Chapter 6 defines two alternative compliance methods. Chapter 7 proposes a text for the standard.

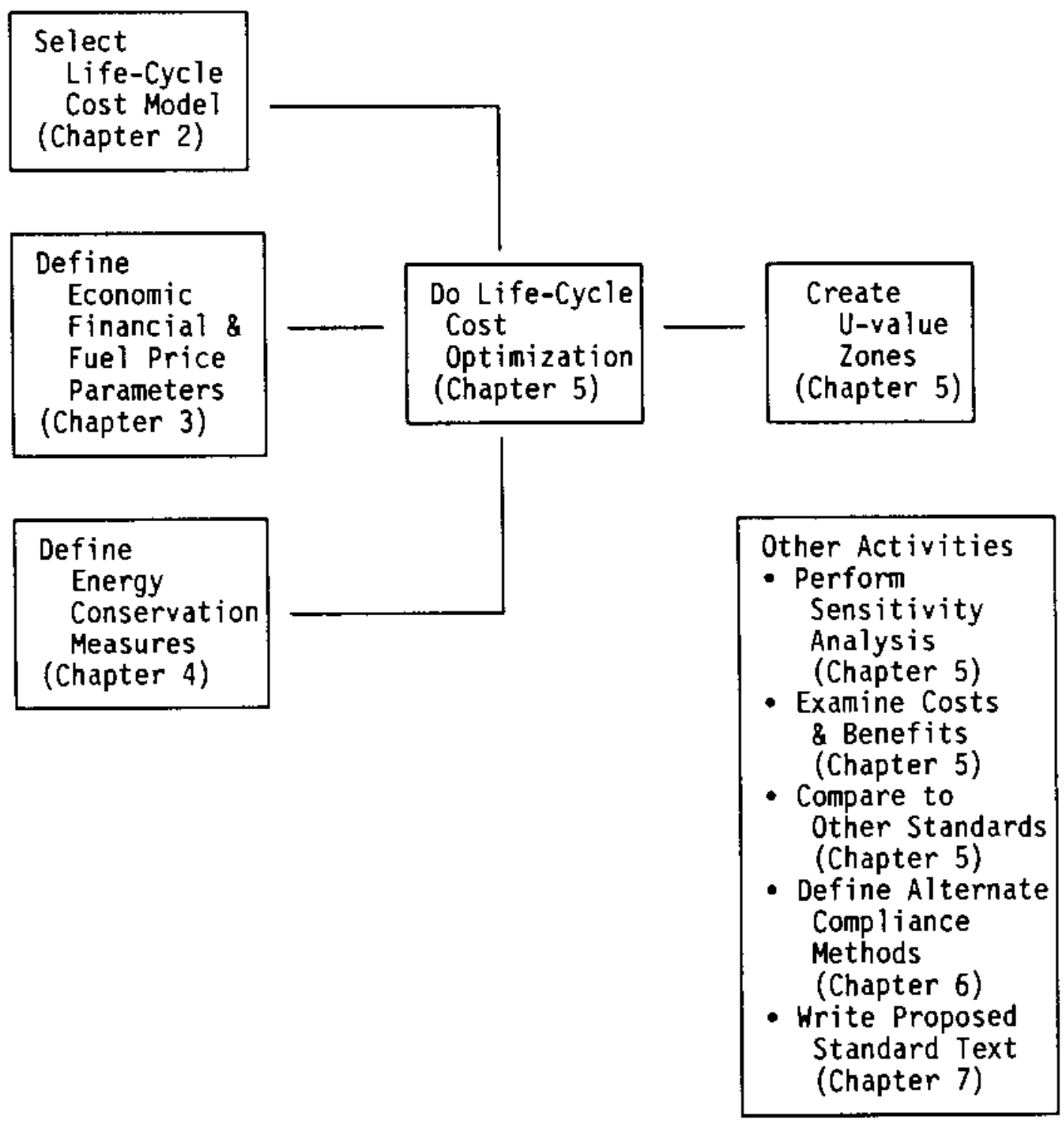

FIGURE 1.1. Major Standard Development Activities 


\subsection{LIFE-CYCLE COST MODEL}

This chapter describes the selection of the life-cycle cost model used to generate the HUD standard. Section 2.1 describes the legislative requirements as they relate to selection of the model. Section 2.2 describes a generic life-cycle cost analysis. Section 2.3 briefly describes the model selected.

\subsection{LEGISLATIVE REQUIREMENTS PERTAINING TO OPTIMIZATION}

The Housing and Community Development Act of 1987 and the accompanying conference reports (CRH 1987; CRS 1987) define the type of optimization method that is to be used to set the standard. The optimization methodology should be chosen to "ensure the lowest total of construction and operating costs." (HCDA 1987). The methodology is required to "result in the lowest possible total cost taking into consideration down payment, financing, construction, and energy costs" (CRH 1987). The method was specified to be "a life cycle cost analysis" (CRS 1987).

\subsection{LIFE-CYCLE COST ANALYSIS}

Life-cycle cost (LCC) methods are used to compare the total long-run (present value) dollar costs achieved through several alternative courses of action. The course of action that achieves the objective for the least cost is typically the preferred alternative. The general approach of the LCC method is to sum the (discounted) costs and benefits of the investment, which, in turn, are calculated based on existing and forecasted economic parameters. For the analysis to be credible, the parameters used in the analys is must properly reflect present or expected market conditions.

The basic cost elements of the generic LCC method are shown below. All costs and benefits are computed in present value dollars.

$$
\begin{aligned}
\text { Life-cycle cost }= & \text { Initial investment }+ \text { Operating costs } \\
& + \text { Maintenance costs }- \text { Resale value }
\end{aligned}
$$


The first element represents the initial investment outlay. For this analysis, that outlay would represent the purchase and financing of manufactured home ECMs. The second element is the cost of operating the building. This represents the cost of the energy required to keep the building comfortable. A reduction in the energy costs is the basic benefit of the standard. The third element represents the operation and maintenance outlays required to maintain the investment following its purchase. For the standard, this represents the maintenance, repair, or replacement required for the ECMs. The final element represents the resale or scrap value of the investment after it has reached the end of its expected useful life. This is the resale value of the ECMs at the end of the analysis period.

\subsection{AUTOMATED RESIDENTIAL ENERGY STANDARD}

This analysis to develop the standard was done with the Automated Residential Energy Standard (ARES) program. The ARES software is a computer program developed for the U.S. Department of Energy (DOE) for the Voluntary Residential Standard.(a) The ARES implements a life-cycle cost methodology for residential energy conservation decisions. Given a set of fuel price, financial, economic, and ECM costs for a building at a specific location, ARES identifies the set of ECMs to invest in, such that the homeowner's total life-cycle cost is minimized. ARES was designed specifically for the development of residential energy conservation standards.

Besides a life-cycle cost model, ARES incorporates an energy simulation model allowing ARES to project the energy use for a selection of specific ECMs. The energy usage associated with each ECM by ARES becomes an input to the ARES life-cycle cost analysis. The incorporation of an energy simulation in ARES removes the requirement for doing separate building energy simulations, since the simulation is internal to ARES. The ARES energy simulation is a parameterization of a large data base of DOE-2 simulations and, therefore, the

(a) This document focuses on the work that is unique to the development of the HUD standard; ARES is documented by Lortz and Taylor (1989). 
energy savings projected by ARES are based on the U.S. Department of Energy's DOE-2 simulation program. (a)

The Automated Residential Energy Standard generates an optimum for a home in a specific city using a specific heating system and fuel. ARES does not generate an optimum for a group of cities or a climate zone. The aggregation of the individual optimum $U$-values is done as a separate series of steps, which are described in Chapter 5.

(a) The House Conference Report specifically states: "In developing these standards, HUD should assume reasonable levels of air infiltration,... and solar heat gain through glazing" (CRH 1987). The DOE-2 data base assumes an air infiltration of about $0.5 \mathrm{ACH}$ (air changes per hour), which is probably near the median of the range of values for homes currently produced in the U.S. DOE-2 explicitly models the solar heat gain through glazing. 


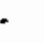




\subsection{FINANCIAL, ECONOMIC, AND FUEL PRICE PARAMETERS}

In this chapter the financial, economic, and fuel price parameter values necessary to develop the cost-effective manufactured housing standards for HUD are specified, justified, and documented. Section 3.1 describes the legislative requirements as they relate to the selection of these parameters. Section 3.2 defines the financial parameters and documents their sources. Section 3.3 deals with economic parameter selection. Section 3.4 discusses the selection of state fuel price and fuel escalation rates. Most of the financial, economic, and fuel price parameters required for input to this analysis are listed below.

- Manufactured home finance parameters (selected values in parentheses)

-- mortgage interest rates (14\%)

- loan term (14 years)

-- down payment (15\%)

- loan fees and points (1\% in total)

- Other rates and times

-- discount rate $(7 \%$ real)

-- inflation rate (4.9\%)

-- period of analysis (33 years)

-- building lifetime ( 33 years)

-- property tax rates $(2 \%)$

- Residential fuel prices by state (see Appendix A for values)

-- electricity

- fuel oil

-- natural gas

-- liquid petroleum gas (LPG)

- Residential fuel price escalation rates (see Table 3.3, page 3.11)

-- electricity (averaged $0.0 \%$ per year or constant)

-- fuel oil (averaged 2.5\% per year)

. natural gas (averaged $2.0 \%$ per year)

-- LPG. (averaged 2.3\% per year)

In choosing the parameters for analysis of the standard, the intent was to identify and to document the best source available for each parameter. Most of the parameter values are commonly reported statistics and are traceable to other published sources. It should be noted that some of the parameter values vary across time, locations, markets, institutions, circumstances, and/or individuals. In general, the mean value was taken for any particular parameter. If multiple sources for a single parameter were identified, an 
attempt was made to choose the best source, with a bias towards both the most recent source and the best documented source.

\subsection{LEgISLATIVE REQUIREMENTS PERTAINING TO PARAMETER SELECTION}

The Housing and Community Development Act of 1987 and the accompanying conference reports (CRH 1987; CRS 1987) set requirements that affect the selection of the parameters. (The text is in Appendix J.) Three of the requirements apply to the economic, financial, and fuel price parameters and the selection of optimal ECM levels. The statutory requirements describe

- the optimization methodology

- the perspective used to define the costs and benefits

- the period of analysis.

The optimization methodology should be chosen to "ensure the lowest total of construction and operating costs" (HCDA 1987). The methodology is required to "result in the lowest possible total cost taking into consideration down payment, financing, construction, and energy costs" (CRH 1987). The optimization method was specifically defined as "a life-cycle cost analysis" (CRS 1987). (The life-cycle cost model selected was discussed previously in Chapter 2; this chapter discusses the selection of the parameters for the life-cycle cost analysis).

The standard is to be developed using "costs to the manufactured home owner" (CRH 1987). Therefore, all costs and benefits were calculated from the homeowner's perspective.

The costs and benefits are to be considered for the "home over its estimated useful life" (CRH 1987). This is clarified as "the effective physical life of the structure" (CRS 1987). In addition, all statutory references are to owner(s) of the manufactured home; not to the first owner, new homeowner, or home buyer; supporting the building's lifetime as the analysis period. Therefore, the period of analys is was the manufactured home's physical lifetime. 


\subsection{FINANCE PARAMETERS}

Eighty-one percent of new manufactured homes purchased are financed (Foremost Insurance Group 1988). Therefore, development of the standard was based on a manufactured home purchased with financing. Several financing parameters affecting the cost and duration of the loan need to be defined. These parameters are the mortgage interest rate, loan term, down payment, points, and loan fees.

\subsubsection{Mortgage Interest Rate}

A mortgage interest rate of $14 \%$ was selected for this analys is, based on current rates and the average rate for 1984 to 1986 . The two types of manufactured home financing are direct (financing directly from the lending institution) and indirect (financing through the dealer). The average most common interest rates for both types of financing were reported for 1984 to 1986 (Meetings+Plus 1987) and are shown in the first two rows of Table 3.1. (a) The direct and indirect rates were weighted by the fraction of manufactured homes purchased with direct and indirect financing, $13.3 \%$ and $86.7 \%$, respectively (Manufactured Housing Institute [MHI] 1986, p. 27), to produce the average rate, slightly above $14 \%$, shown in the third row of Table 3.1 . The cumulative 1988 rates for manufactured home financing are estimated to be about $13 \%$ (b) or $13.5 \%$ (c) (Florida Manufactured Housing Industry Report 1988; U.S. Federal Reserve 1988). As of September 1988, the rate has gone to about $14 \%$. $b, c)$ Because $14 \%$ is near the rates over much of the last few years and nearly the 3-year average below, 144 was used in this analysis.

TABLE 3.1. Reported Interest Rates (Percent)

\begin{tabular}{|c|c|c|c|c|}
\hline & 1984 & 1985 & 1986 & Average \\
\hline Direc & 15.39 & 14.53 & 13.27 & 14.40 \\
\hline & 15.43 & 14.25 & 12.96 & 14.21 \\
\hline (e) & 15.42 & 14.2 & 13.00 & 14.24 \\
\hline
\end{tabular}

(a) This source did not contain data for later years.

(b) Personal communication, Richard W. Stagman, Vice President, Foremost Financial Services, September 1988.

(c) Personal communication, William J. Owens, Vice President for Finance, Manufactured Housing Institute, September 1988. 


\section{2 .2 Loan Term}

The average loan term for 1985 was reported to be 11.5 and 13.4 years for single- and double-wide manufactured homes, respectively (MHI 1986, p. 4). The average loan term has been reported to be 13.8 years in 1987 (Foremost Insurance Group 1988, p. 18) and about 15 years ${ }^{(a)}$ in 1988 . Because 13.8 is the most recent reported value in the literature and falls within the range of the other reported values, the loan term of 13.8 was rounded to 14 years for this analysis.

\subsubsection{Down Payment}

According to $\mathrm{MHI}$, the average down payment for manufactured homes was 15.1\% for single-wide homes and 15.5\% for double-wide homes (MHI 1986, p. 13). This was rounded down to a 158 down payment for this analysis. (b)

\subsubsection{Points and Loan Fees}

Estimates of the average points associated with manufactured home financing vary. The average points have been estimated at $0.5 \%(c) ; 1$ to 2 , but closer to $1 \%(a) ;$ and 1 to $2 \%(d)$ for new manufactured home loans. Loan fees on manufactured housing are generally a fixed rate, so that there is no incremental loan fee for energy conservation measures. $(a, c, d)$ Based on these appraisals, the total points and loan fees were estimated at 18 for this analysis.

\subsection{ECONOMIC PARAMETERS}

For this analysis, a discount rate, inflation rate, and period of analysis need to be established.

(a) Personal communication, Richard $W$. Stagman, Vice President, Foremost Financial Services, September 1988.

(b) In a personal communication, September 1988, Richard W. Stagman (Vice President, Foremost Financial Services), stated that $15 \%$ was a reasonable estimate of the overall average down payment.

(c) Personal communication, David Leichey, manufactured housing finance consultant from Meetings+Plus, September 1988.

(d) Personal communication, William J. Owens, Vice President for Finance, Manufactured Housing Institute, September 1988. 


\subsubsection{Discount Rate (Alternative Investment Rate)}

A life-cycle cost analysis must convert costs and benefits occurring over future years into present dollars. To convert future dollars into present dollars, a discount rate needs to be established. Six possible discount rates are discussed here. Two types of rates pertain to a social perspective; four different private rates pertain to an individual's perspective. The six rates are

- the risk-free social rate

- the social rate for the analysis of government programs

- the private rate for the time value of money or implicit discount rate

- the private rate charged for credit for consumer purchases

- the private market rate for personal monetary investment

- the private manufactured home mortgage loan rate.

Arguments could be made in favor of each these rates for use in this analys is. Accordingly, these arguments are discussed below.

For social discount rates, it could be argued that the objective of HUD's manufactured home energy conservation standards is to reduce energy consumption for society as a whole. One social rate is the risk-free rate, which is usually specified as the cost of government borrowing (i.e., an essentially risk-free market). In this case, the rate on long-term government bonds is one possible rate. In recent years the long-term government bond rate has been about $7 \%$ to $9 \%$.

Another social rate is used for analyzing energy conservation investments made by government programs and projects. The Energy Security Act of 1980 requires the use of a $7 \%$ (real) discount rate in evaluating energyconservation projects. This is the rate that HUD would be required to use for energy conservation projects undertaken with HUD funds. Adding the $4.9 \%$ inflation rate, which is discussed later, this would become a nominal discount rate of about $12 \%$.

Another alternative rate is the time value of money, or implicit discount rate. This rate represents the private rate of return that an individual 
consumer requires from a purchase. The strongest argument for this rate is that the purpose of HUD's standard is to properly reflect the interests of the consumer of manufactured housing "services" and, therefore, the consumer's preferences most appropriately reflect those interests.

The consumer's implicit discount rate (time value of money) is usually determined by examining consumer behavior when given a range of options. For instance, consumers can purchase a wide range of air-conditioners at various efficiencies. Data on the mix of efficiencies actually purchased and the purchase price can be used to define the price the consumer appears to be willing to pay for energy dollar savings resulting from increases in appliance efficiency. In practice, discount rates are difficult to determine, with an extremely wide range of discount rates having been reported. The rates vary greatly across individuals and incone levels. Usually uncertainties, such as the uncertainty about whether the consumer has sufficient information to compare options, complicate determining the rate. According to the Electric Power Research Institute (EPRI), discount rates varying from less than $2 \%$ to well over $100 \%$ have been reported for purchases related to energy efficiency (EPRI 1988, p. 2-22). In our opinion, studies of the implicit discount rates generally would suggest higher discount rates than those found in the monetary investments described below. Because of the wide variation in reported rates, the consumer's private rate of time preference, as demonstrated by the evidence of consumer purchases, was too indeterminate for this analys is.

Another possible rate is the rate charged for credit card purchases. The interest rate charged for credit card purchases ranges from about $12 \%$ to $22 \%$. The argument for the appropriateness of that rate is based on the fact that many consumer durables (such as washers, dryers, and dishwashers) are purchased through the use of a credit card and paid for over time. An argument against the use of that rate is that, in this analysis, the consumer is actually purchasing additional ECMs in a manufactured home, not a new appliance. Because of that distinction, the consumer has access to a different credit market than that typically used to purchase a new appliance.

When considering credit card interest rates as an indicator of discount rates, it is important to examine the interest actually charged crdit card consumers and the non-monetary benefits of credit card use. Many consumer pay 
off credit card bills before they are charged interest, indicating their discount rate is below that charged by the credit card. Additionally, many credit cards have a "grace period" between the consumer purchase and initiating the interest charge, lowering the effective interest rate charged. Finally, non-monetary reasons (such as the need to track expenses) sometimes provide a reason for using credit cards. For these reasons, credit card rates are not good indicators of consumer discount.

One alternative is to select the most comon interest-bearing investment made by owners of manufactured homes. Passbook savings accounts (often yielding $5 \%$ to $6 \%$ ) may be the most common form of interest-bearing investments for these homeowners. However, with the $4.9 \%$ inflation rate selected for this analysis the real rate of return (savings interest less inflation) becomes about $0 \%$ to $1 \%$, which is equivalent to the assumption that the value of money received in the future is almost the same as money received in the present. For that reason, the passbook savings rate is clearly too low for this analys is.

Another possible rate is the market rate for monetary investments. Consumers have access to a number of common market rates; passbook savings, U.S. savings bonds, and certificates of deposits (CDs) are the most common. These investments are relatively risk-free and have a moderate to high degree of liquidity. These alternative investments can be used for comparison to investments in energy conservation measures. Using the consumer's alternative monetary investments for comparison, "The discount rate should reflect the rate of return that will be foregone if the project in question is undertaken instead of the next best alternative investment opportunity of similar risk; that is, it should reflect the 'opportunity cost' of the project." (Ruegg and Petersen 1987, p. 17). This criterion requires selecting the consumer's best available rate of return with comparable risk, probably CDs. Short-and medium-term CDs usually yield about $7 \%$ to $9 \%$. Note, these are pre-tax rates. Another alternative "investment" for the consumer, which is comparable to the market rates for investment, is prepayment of the mortgage. In determining the rate of return from the prepayment alternative, the loss of the tax deduction for mortgage interest (if any) and loan prepayment penalty (if any) need to be considered. (Savings from energy conservation are tax-free.) 
Assuming no loan prepayment penaity, the net rate available to the homeowner who deducted the interest from his taxes for an "investment" in mortgage prepayment would be about $11.5 \%$. (a) If mortgage interest is not deducted on taxes, this "investment" earns 14\%. In contrast to most of the other investments, prepaying the mortgage would cost the consumer liquidity. An argument for using the mortgage interest rate (at a minimum) is that the home buyer has borrowed money at that rate, demonstrating that his implicit discount rate must be at least that high.

Using the criterion that the standard is required to be developed based on "costs to the manufactured home owner" (CRH 1987) using "the next best alternative investment opportunity" (Ruegg and Petersen 1987, p. 17), then the best rate of return commonly available to the owner of the manufactured home is mortgage prepayment. For a $14 \%$ mortgage, this "investment" yields between $11.5 \%$ and $14 \%$ (nominal). As the best (highest rate of return) alternative, mortgage prepayment was selected to define the range of possible discount rates. Because it is within this range and is the rate generally used for federal energy life-cycle cost analyses (Energy Security Act of 1980), the real discount rate of $7 \%(12 \%$ nominal, if the $4.9 \%$ inflation rate is added) was used in this analysis.

\subsubsection{Inflation Rate}

The inflation rate is used to convert between the nominal and real rates used in this analysis. The nominal rates (that include inflation) are the mortgage and discount rates. The fuel escalation rates, described later in this section, are real rates. The most recent DOE base-case forecast of the long-range Gross National Product (GNP) implicit price deflator is 4.98 (Energy

(a) The 1987 median income of manufactured-home buyers was $\$ 21,900$ (Foremost Insurance Group 1988, p. 15). About $62 \%$ of the manufactured-home residents are married (Foremost Insurance Group 1988, p. 6). The 1988 marginal federal income tax for married couples, with income up to $\$ 29,750$ is $15 \%$. Therefore, the appropriate federal income tax, is $15 \%$. Based on a brief review of state taxes (U.S. Department of Commerce 1986), the average marginal state income tax was estimated to be $3 \%$. The $14 \%$ return less the tax deductions of $18 \%$ ( $15 \%$ federal plus $3 \%$ state), yields an estimated $11.5 \%$ return. Note, this assumes no loan prepayment penalty, which would further lower the return to the home owner. 
Information Administration 1989, p. 54), which was used as the inflation rate for this analysis.

\subsubsection{Period of Analysis and Building Lifetime}

The statutory requirements for development of the standard set the "estimated useful life" (CRH 1987) as the period for the life-cycle cost analysis. This period is clarified as the "effective physical life of the structure" (CRS 1987). Because the standard applies to new manufactured homes, the estimated life was that of a newly constructed home. In 1980 the useful life of a manufactured home was estimated to be 31 years for single-wide and 30 years for double-wide homes (Boeing Aerospace Company 1980, p. xiii). The 1 ifetime for newly constructed homes is apparently increasing (Gates 1986). Some lending institutions, including HUD, currently provide 30-year loans on manufactured housing when accompanied by land, indicating that the useful life of some manufactured homes is at least 30 years. The average useful life for new manufactured homes that are continuously occupied has been estimated at 33.4 years (Gates 1986), which was rounded to 33 years. Therefore, a 33-year building lifetime was used as the period of analysis.

The discount rate $(7 \%$ real) diminishes the value of future dollars such that periods far into the future do not have a major impact on the analys is. To illustrate this, the value of a $\$ 1$ per year savings for the three decades of a manufactured home's life is shown in Table 3.2. Note that although $\$ 10$ is saved in each 10-year period, the third decade is worth less than oneseventh of the cumulative savings. Therefore, small changes in the lifetime of a home which already has a long lifetime would not make a significant difference in this analysis. For example, there is only a small difference between an analysis period of 30 years and 32 years, with the $\$ 3.00$ in the last 3 years valued at only $\$ 0.34$.

Because the building lifetime is the period of analysis, the resale value for the ECMs is depreciated to zero at the end of the analysis period. 
TABLE 3.2. Value of $\$ 1$ per Year Savings

\begin{tabular}{|c|c|c|}
\hline Years & Savings, $\$$ & Present value, $\$$ \\
\hline $1-10$ & 10.00 & 6.99 \\
\hline $11-20$ & 10.00 & 3.52 \\
\hline $21-30$ & 10.00 & 1.77 \\
\hline $1-30$ & 30.00 & 12.28 \\
\hline $1-33$ & 33.00 & 12.62 \\
\hline
\end{tabular}

\subsubsection{Property Tax Rate}

Property taxes vary widely from state to state and within a particular state. The EPRI has recomended a levelized value of $2 \%$ for property taxes and insurance (EPRI 1982). Many owners of manufactured homes do not pay property taxes because such homes are sometimes classified as personal property rather than real property; however, they will often pay personal property taxes that are estimated to be approximately equivalent.(a) Therefore, a rate of 28 is estimated for property/personal taxes on manufactured housing.

\subsubsection{Income Tax Rate}

The marginal income tax rate paid by the homeowner determines the value of the mortgage tax deduction. However, most owners of manufactured homes do not itemize their income tax deduction. Therefore, the income tax rate used as input to ARES was $0 \%$, so that the life-cycle cost calculation done by ARES would reflect the fact that most homeowners do not itemize their income tax deductions. (b)

\subsection{FUEL PRICE PARAMETERS}

Both current fuel prices and fuel price escalation rates were required for this analysis.

(a) Personal communication, William J. Owens, Vice President of Finance, Manufactured Housing Institute, September 1988.

(b) Manufactured home owners generally take the standard deduction on their income tax. ARES uses the income tax rate only to determine the value of tax deductions; therefore, the tax rate input to ARES was $0 \%$ 


\subsubsection{Fuel Price Data}

The average residential fuel price used in each state for electricity, distillate fuel oil, LPG, and natural gas is shown in Table A.1 of Appendix A. Residential energy prices from an Energy Information Agency report, State Energy Price and Expenditure Report (EIA 1988), were used for development of the standard. These 1986 fuel prices for each state were updated for the fuel price escalation in 1987 and 1988 (U.S. Department of Conmerce 1988). The summer/winter variation in electricity prices was accounted for as described in Appendix A (Tables A.2 and A.3).

\subsubsection{Fuel Price Escalation Rates}

The residential fuel escalation rates (real) displayed in Table 3.3 were taken from a report prepared for the Federal Energy Management Program (FEMP) (National Institute of Standards and Technology [NIST] 1988). The FEMP projects fuel escalation rates for 5-year periods for each fuel used in this analysis.(a) The ARES software, which was used to do the life-cycle analysis, requires a single rate for each city but allows a separate fuel escalation rate for each fuel. Therefore, the price escalation rates for the 1988 to 2021 period of analysis were resolved to a single value for each fuel. Over the 33-year analysis period, the fuel escalation rates shown below will yield the same present value, accounting for the discount rate, due to energy savings as the set of rates projected by FEMP. The FEMP projects separate escalation rates for the four U.S. census regions; therefore, separate rates were used in each census region. It should be noted that another DOE source for fuel escalation rates projects similar but higher fuel price escalation rates (EIA 1989 , p. 47). The FEMP rates were selected over the EIA rates because the FEMP rates were more conservative in projecting lower fuel escalation rates and because of the FEMP resolution into the four U.S. census regions.

(a) Rates for 2014 to 2021 were not projected by NIST (1988) so the 2013 rates were used for that period. The 2013 rates were low, always below $1 \%$. Given that the last 8 years are heavily discounted, the effect of this assumption on the overall rate was small. 
TABLE 3.3. Residential Fuel Price Escalation Rates (Percent) for 1988 through 2021 by U.S. Census Region

\begin{tabular}{|c|c|c|c|c|}
\hline Fuel & $\begin{array}{l}\text { North- } \\
\text { East }\end{array}$ & $\begin{array}{r}\text { North- } \\
\text { Central } \\
\end{array}$ & South & West \\
\hline Electricity & 0.1 & -0.2 & -0.1 & 0.4 \\
\hline Fuel oil & 2.5 & 2.6 & 2.5 & 2.6 \\
\hline Natural gas & 1.7 & 2.0 & 2.0 & 2.0 \\
\hline Liquid petroleum gas & 2.1 & 2.5 & 2.3 & 2.3 \\
\hline
\end{tabular}




\subsection{ENERGY CONSERVATION MEASURES}

The analysis used to develop the recomnendations for revision of the HUO manufactured housing energy conservation standard requires information on specific ECMs. This analysis determines the homeowner's optimum investment in energy conservation by minimizing the sum of the costs (including ECM purchase) and benefits of an investment in energy conservation using a lifecycle cost analysis. The ECMs characterized in this report are considered as a)ternative construction options that can be compared to determine the most cost-effective package of options that, in turn, provides the basis for the standard.

This chapter primarily documents the characterization of the ECM options used in the life-cycle cost analysis. Section 4.1 discusses the legislative requirements as they pertain to ECM selection. Section 4.2 lists the type of information about ECMs that is required by this analysis. Section 4.3 describes the data sources used to define the ECMs and their characteristics. Sections 4.4 and 4.5 discuss the prototype homes and base level characteristics selected for the analysis. Section 4.6 presents the analys is of ECM costs and characteristics data, including selection of ECMS and determination of costs for insulation in ceilings, walls, and floors; determination of the types and costs of the window and door options; and discussion the HVAC systems and infiltration options. Section 4.7 defines the wholesale-to-retail price multipliers. The final Sections discusses ducts.

\subsection{LEGISLATIVE REQUIREMENTS FOR ENERGY CONSERVATION MEASURE SELECTION}

The law requiring revision of the HUO MHCSS (24 CF 3280) energy conservation standards (HCDA 1987) and the accompanying conference report (CRH 1987) set requirements that affect the selection of the ECMs reported here. For purposes of this report, both the $\mathrm{law}$ and the congressional report were treated as requirements. Several of the statutory requirements apply to the ECM characterization. The statutory requirements specify

- the perspective used to define the costs and benefits

- consideration of manufactured home design and factory construction techniques 
- separate evaluation of single- and double-wide homes.

The effects of these requirements on the ECM characterization are described below.

The standard is to be developed using "costs to the owner of a manufactured home" (CRH 1987). Therefore, all costs and benefits were calculated from the homeowner's perspective, with costs expressed at the retail (as opposed to wholesale) level.

The requirement to consider "factory construction techniques" (HCDA 1987) was strictly interpreted to consider exclusively the technology currently used commercially by at least a portion of the manufactured home industry. To limit the technologies to those conmercially available, we made the requirement that at least four different manufacturers report (based on surveys described later) that a specific ECM option was offered in a manufacturer's product line. (a)

The requirement to consider "design ... of manufactured homes" (HCDA 1987) was interpreted to require consideration of common configurations used in manufactured homes. Therefore, prototype(s) were defined by examining typical manufactured home dimensions and the range of manufactured home dimensions were considered. The requirement concerning design was clarified in the congressional report (CRH 1987) by requiring separate consideration of singleand double-wide homes. Therefore, the distinction between ECM characteristics for single- and double-wide homes was made when appropriate.

\subsection{ENERGY CONSERVATION MEASURE CHARACTERISTICS REQUIRED}

Energy Conservation Measure option characteristics must be determined for all manufactured home components. (b) These components include

(a) Although we believe this interpretation is consistent with the legislative requirements, it is conservative and eliminated a number of technically feasible ECM options identified in the survey of manufacturers.

(b) Ducts were not included in the overall U-value. Congress required that the "heat loss coefficients [Uo]" be established for the "overall envelope area" for a home (CRH 1987). This suggests ducts were not to be included in the U-value. Ducts were therefore handled separately. 
- ceilings

- walls

- floors

- windows
- doors

- heating/air-conditioning equipment

- infiltration.

Special considerations, which are discussed later, apply to space conditioning equipment and infiltration. For each component, a list of ECM options and associated characteristics (if appropriate) were produced, including

- ECM option description

- U-value
- cost

- lifetime.

Data for producing the ECM options list and individual ECM costs come primarily from surveys of manufactured-home manufacturers. The calculation of U-values for each ECM is described in Appendix B.

It should be emphasized that the inclusion of an ECM in the ECM options list does not imply that ECM became a requirement of the standard. The ECMs selected for calculation of the optimum U-value were determined by the lifecycle cost optimization. Furthermore, the standard was specified in terms of overall U-value, not component U-value or specific ECMs.

Other ECM-related information was also required for the analysis. The dimensions of prototypical single- and double-wide manufactured homes were based on national survey data. The markups from wholesale-to-retail costs were based on the same survey data.

\subsection{ENERGY CONSERVATION MEASURE DATA SOURCES}

Several sources of information were utilized to develop ECM data. This section discusses each major data source and the information available from it.

\subsubsection{Manufacturer Surveys}

In 1987, PNL performed a study for HUD on the impacts of alternative manufactured housing energy standards. At the time, HUD was examining the consequences of deregulating the energy standard portion of the MHCSS. The 
results of that study were presented to HUD(a) and at a briefing to HUD's National Manufactured Home Advisory Council on October 29, 1987.

In the course of conducting the study for HUD, PNL conducted interviews with 83 manufacturing plants (b) in 22 states throughout the United States, excluding the Pacific Northwest which was handled separately in the survey described below. The locations and manufacturers were selected to take into account the geographic regions, climates, and the distribution of production throughout the country. The survey instrument and data are presented in a separate document (Lee and Conner 1989).

In addition to the HUD survey. PNL collected manufacturers' data in the Pacific Northwest during mid-1987. The data were collected for a study sponsored by the Bonneville Power Administration (BPA). The interview instrument, data, supplemental data (from manufacturers' literature and price sheets), and results of the analysis were presented in a prior study (Harkreader et al. 1987). The BPA study complemented the HUD study by covering only the Pacific Northwest. Information was obtained from 15 of the 17 manufacturers in the region at that time.

Figure 4.1 shows the number of manufacturing plants in each state surveyed by the combined HUD and BPA surveys. This can be compared to the total number of manufacturing plants by state(c) in Figure 4.2. In total, 98 manufacturing plants (about one-third of the national total) were surveyed. The two surveys covered 25 of the 37 states that had manufacturing plants when the survey was performed. (Eleven states had no manufacturing plants.) Given the distribution of the plants surveyed, the HUD and BPA surveys provide good coverage of the United States. (These surveys also provided the information required to examine regional cost variations as described in Section 4.7.2.)

(a) By R. J. Nesse, 1987, Pacific Northwest Laboratory, Richland, Washington.

(b) References in this report to manufacturers refer to specific manufacturing plants that were surveyed, rather than the whole of any specific company. Individual companies may have several plants in different states. In aggregating the plant data, each surveyed plant is given equal weight rather than weighting by number of units produced.

(c) The total figure includes only manufacturers who produced HUD-code homes according to Manufactured/Mobile Home Merchandiser, November 1986. (In a few cases this source may not have noted that some of the producers made HUD-code homes. An attempt was made to correct this in the figure.) 


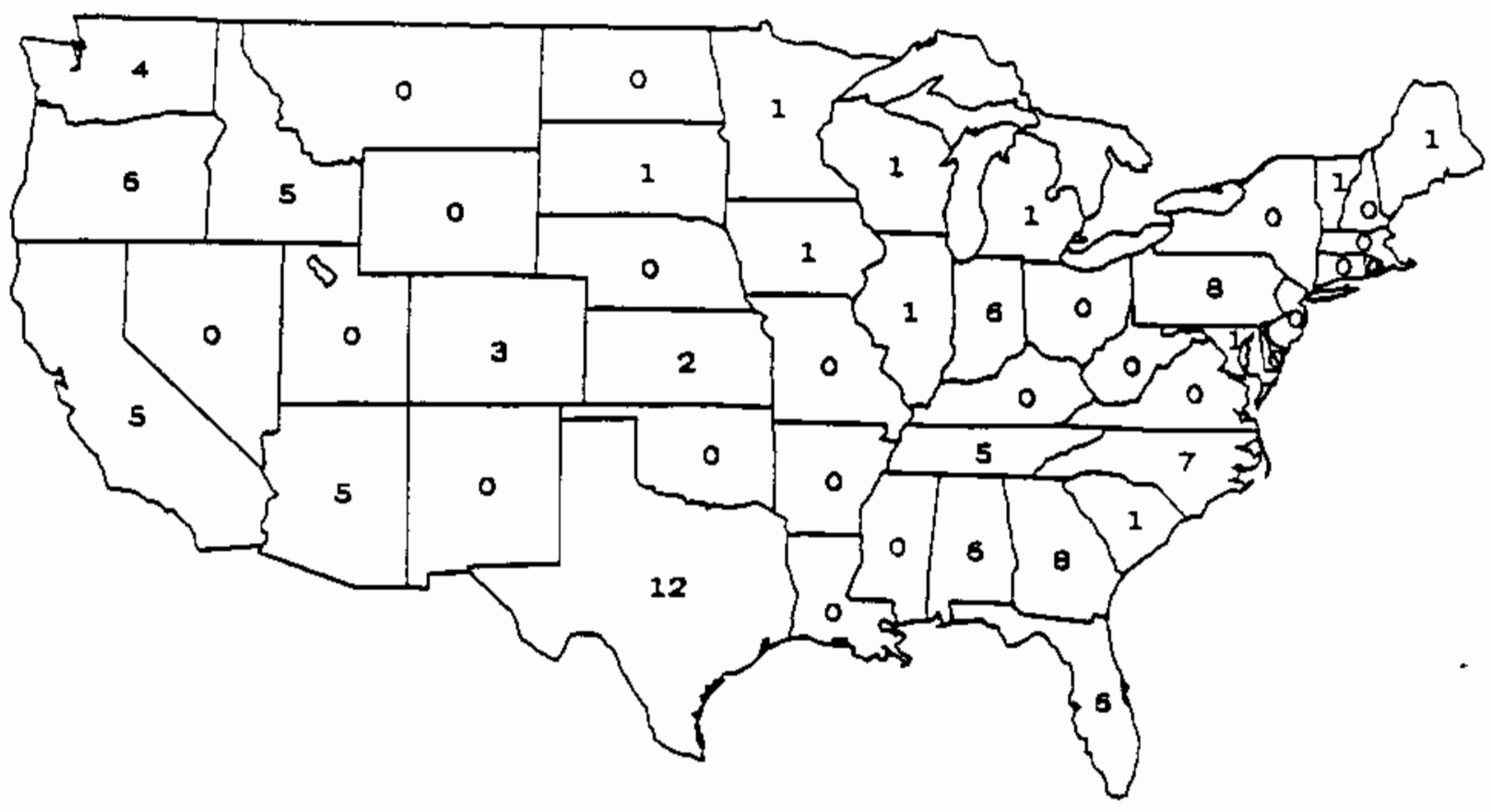

FIGURE 4.1. Manufacturing Plants Surveyed

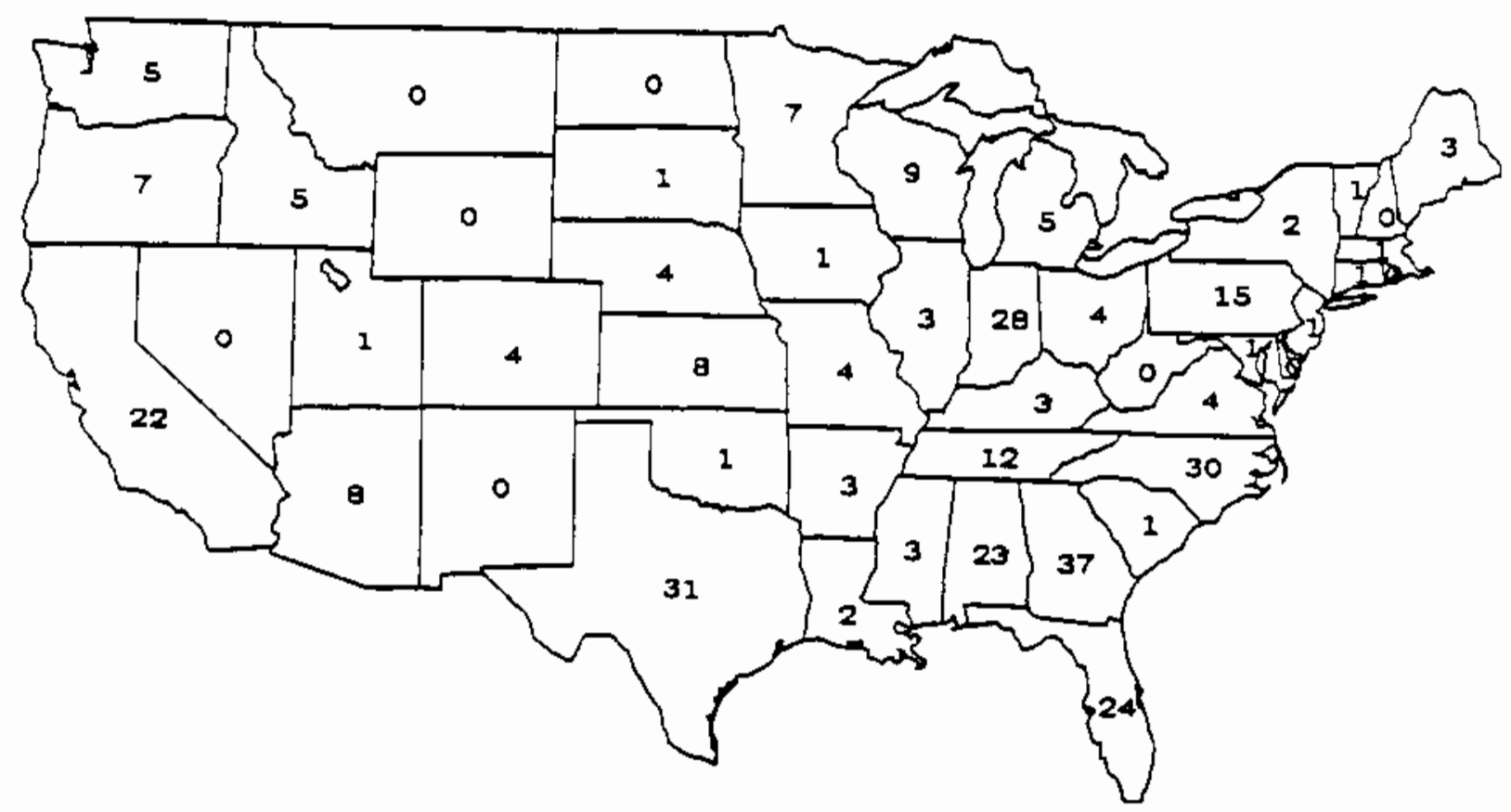

FIGURE 4.2. Total Number of Manufacturing Plants 
The HUD and BPA surveys provided the majority of the information required for the generation of the ECM options list. Both surveys included data by manufacturing plant on

- the ECM options offered for ceilings, walls, windows, floors, and doors for single- and double-wide homes, including costs for each ECM

- the most commonly sold home dimensions and ECM levels

- the markups from wholesale prices to retail prices.

In the following sections, any data on manufacturing plants not specifically identified as to source came from the HUD and BPA surveys.

\subsubsection{Window Data Survey}

A telephone survey of manufacturers was conducted in 0ctober 1988 to collect data on window characteristics and costs (Lee and Conner 1989). The sample design followed the same specifications as the HUD and BPA surveys. Interviews were completed with representatives of 50 plants distributed around the country. The window survey collected information on the range of windows currently offered in manufactured homes. Manufacturers described the features of the windows provided as standard equipment and all options that they offered to consumers. The following characteristics data were obtained

- typical window area

- typical number of windows per home

- frame types

- number of panes

- air gap thickness in multiple pane windows

- whether a thermal break was available in aluminum sash windows

- whether low-enissivity (low-e) glazing was offered

- whether glazings were tinted or clear

- whether a storm window was present

- incremental wholesale cost for window options

- whether other features were included in optional windows that affected the price. 


\subsection{PROTOTYPE SINGLE- AND DOUBLE-WIDE HOMES}

This analysis required prototypical single- and double-wide homes. Defining these prototypes meant selecting representative home dimensions and glazing areas. In our surveys manufacturers provided information on the dimensions of their most commonly sold single- and double-wide homes. (a) Except as noted, the median values were chosen for the single- and doublewide prototypes, as shown in Table 4.1. In general variations between manufacturers and regions were small. The one exception was the large variation in window area.

TABLE 4.1. Prototypical Home Characteristics $(b, c, d)$

\begin{tabular}{|c|c|c|c|c|c|c|}
\hline Prototype & $\begin{array}{l}\text { Length, } \\
\mathrm{ft}\end{array}$ & $\begin{array}{c}\text { Width, } \\
\mathrm{ft}\end{array}$ & $\begin{array}{l}\text { Height, } \\
\begin{array}{l}\mathrm{ft} \\
\end{array}\end{array}$ & $\begin{array}{l}\text { Floor } \\
\text { Area, } \mathrm{ft}^{2}\end{array}$ & $\begin{array}{c}\text { Window } \\
\text { Area, } \% \text { of } \\
\text { Floor Area } \\
\end{array}$ & $\begin{array}{l}\text { Door } \\
\text { Area, } \mathrm{ft}^{2}\end{array}$ \\
\hline Single-Wide & 66 & 14 & 7.5 & 924 & $12 \%$ & 36 \\
\hline Double-wide & 56 & 28 & 7.5 & 1568 & $12 \%$ & 36 \\
\hline
\end{tabular}

(b) The height and length for both prototypes and the single-wide width are consistent with those used by Gates $(1984, p .3)$ and Steven Winter Associates (1985, Appendix C). The two referenced documents used 24 feet as the double-wide width; however, our survey shows 24 feet to be only $14 \%$ of our sample. The median of 27 feet only occurred in $4 \%$ of the cases, so the most common width of 28 feet ( $49 \%$ of sample) was selected for the prototype.

(c) The average floor areas are simply the length times width. The door areas, are equivalent to two standard doors.

(d) The median window area for single-wide homes was $11 \%$ of the floor area; the value for double-wide homes was $10 \%$. The distribution was relatively wide; however, and $22 \%$ of the observations had values of $14 \%$ or higher, $6 \%$ were greater than $15 \%$. Twelve percent was selected as a somewhat conservative value. This is the default value used in ARES.

\subsection{BASE AND TYPICAL ENERGY CONSERVATION MEASURE LEVELS}

For purposes of defining the range of ECMs to consider, we needed to determine base levels for each component that would constitute the starting points for cost-effectiveness analyses. In our survey manufacturers were

(a) About $90 \%$ of the manufacturers contacted indicated that they produced both single- and double-wide homes. 
asked the minimum insulation levels they provided, which were used to establish the base levels uses in this analysis. The values tended to be a little higher in double-wide homes than in single-wides. In the ceiling, the lowest level reported was R-10 and the typical minimum value was between $R-11$ and R-14. About $15 \%$ of the manufacturers reported minimum ceiling insulation levels above R-19. The most common minimum floor insulation level was R-11, which ranged from $R-7$ to $R-19$. In the walls, $R-11$ was reported to be the minimum value by about half the manufacturers, with the minimum values ranging from R-7 to R-22. Table 4.2 indicates the base characteristics used in this analysis.

TABLE 4.2. Base and Typical Characteristics

\begin{tabular}{llcccc} 
& \multicolumn{2}{c}{ Wall } & & \\
& R-Value & Dimension & Floor R-Value & Ceiling R-Value \\
Base & R-7 & $2 \times 4$ & & R-7 & R-11 \\
Typical & R-11 & $2 \times 4$ & R-11 & R-19
\end{tabular}

Manufacturers were also asked to indicate their most commonly installed insulation levels. The typical levels averaged a little less than R-1 higher for double-wide homes than single-wide homes in each of the components. Rounded to the nearest commonly installed value, the average typical levels are shown in Table 4.2 .

\subsection{ANALYSIS OF ENERGY CONSERVATION MEASURE COST AND CHARACTERISTICS DATA}

A set of candidate ECMs had to be selected for use in the analysis. These measures constituted the possible options included in the life-cycle cost optimization. A cost was defined for each measure. The selection of measures and the determination of costs are described below.

Appendix $B$ describes the U-value determination. The overall U-values for walls, floors, and ceilings assemblies were calculated presuming possible constructions currently used in the industry. The window and door U-values were defined based on ASHRAE sources, as described in Appendix B. 


\subsubsection{Energy Conservation Measure Cost Determination}

Cost estimations were based on the wholesale ECM costs(a) manufacturers reported charging to dealers in the manufacturer surveys. (b) These surveys requested the incremental wholesale costs for each ECM option above the price of the base model offered by that manufacturer. (c) For instance if a manufacturer offered R-11, R-19, and R-30 ceilings, the additional cost above the $R-11$ was requested for the $R-19$ and $R-30$ ceilings. From these data the possible options and costs(d) were determined. The wholesale costs were later adjusted from wholesale to retail.

The first step in the analysis of the ECM ceiling, wall, and floor cost data was to distinguish between the cost of adding insulation (additional $\mathrm{R}$-vaTue) and the construction changes required above certain points to allow for higher R-values. Once the ranges in which no construction changes occurred were determined, the costs per change in unit R-value (equivalent to the cost of incremental insulation) were resolved. To estimate the incremental cost of an ECM, the change in R-value from one ECM to the next was multiplied by the cost per unit $R$-value change(e) and the prototype(f) component area to produce the component cost. If a construction change was required, for example going from $2 \times 4$ to $2 \times 6$ walls, then the cost of the construction change was also included. With variations, this method was used to determine the ceiling, wall, and floor costs described in Sections 4.6.3 through 4.6.5.

(a) Cost data from 1987 were adjusted to 1988 prices by multiplying by the estimated inflation rate for manufactured housing, 5.6\% (USBLS 1988).

(b) The wholesale prices were adjusted to retail prices using the multipliers presented in Section 4.7 .

(c) For insulation measures, costs were provided for about two-thirds of the options. Manufacturers provided cost data for about three-fourths of the window and door options mentioned.

(d) Costs presented in this section are national averages. In the lifecycle cost analys is these costs were adjusted regionally based on the regional cost multipliers presented in Section 4.7.2.

(e) Using the cost per unit R-value for that specific R-value range.

(f) Shown in Table 4.1. 


\subsubsection{Determining Energy Conservation Measure Options}

As discussed earlier, the legislative requirement (HCDA 1987) to consider the "factory construction techniques of manufactured homes" was interpreted to require consideration exclusively of ECMs used commercially by a portion of the manufactured home industry. Operationally we translated this legal guideline to the requirement that to include an ECM in our analysis, at least four manufacturers must have reported in our surveys that a specific ECM option was offered in one of their homes. Although consistent with our interpretation of the statutory requirement, the requirement that ECMs be in current comnercial use rather than technically feasible eliminated a number of ECMs that have been demonstrated to be currently technically feasible. (a)

\subsubsection{Ceiling Energy Conservation Measures}

Ceiling ECM costs were calculated based on manufacturer's reported costs. First the attempted separation of construction change and insulation costs was made. It was assumed that manufacturers would use trusses with a 2-1/2 inch heel height up to $\mathrm{R}-22$ and would raise the heel height to 5-1/2 inches for higher R-values (b) (OOE 1986). However, when examined for this construction cost increase, the data did not provide evidence of a significant cost increase. Steven Winter Associates (1985) also showed only small costs for this construction change. (c) Assuming no construction cost change is consistent with Gates (1988).

Our ceiling survey data were split into two R-value ranges to capture any variation in cost with $R$-value. The means (d) were calculated for values up

(a) The survey data demonstrated that a few manufacturers currently offer ECM levels above those assumed in this analys is. In addition demonstration programs, such as those sponsored by BPA (Onisko 1986; Riewer 1988), demonstrate technical feasibility for additional ECMs.

(b) Raising heel heights would reduce the compression of the insulation, making the insulation more effective, but could increase construction costs.

(c) Steven Winter Associates (1985, p. 31) estimated increasing the heel height to 5-1/2 inches would cost $\$ 22$ (1984 dollars) for our single-wide prototype $\left(\$ 0.024 / \mathrm{ft}^{2}\right)$, and $\$ 20$ for the double-wide prototype $\left(\$ 0.013 / \mathrm{ft}^{2}\right)$. Because $i \mathrm{t}$ is not separately broken out, the small change associated with the construction costs will have been incorporated in the cost per R-value data in Table 4.3 .

(d) Deleting values greater than two standard deviations from the mean. 
to R-22, and for values above R-22. There was no significant difference between the cost for single- and double-wide homes, so all the data were pooled. It should be noted that manufacturers use both blown and batt insulation and that our estimates are an average cost based on the share of manufacturers in our survey using these insulation types.

Table 4.3 shows that the insulation cost was about $6 \%$ higher for the range of larger R-values. These cost parameters for the insulation were fairly consistent with other estimates. Gates (1988) estimated costs around $\$ 0.022 / \mathrm{ft}^{2} / \mathrm{R}-\mathrm{value}$ for batt insulation. Although his cost estimate was lower than ours, this reference appeared to rely on estimates made in 1984 that were not updated to reflect inflation. Our estimates were within $5 \%$ of the estimates in DOE (1986) after adjusting for inflation.

\section{TABLE 4.3. Ceiling ECM Incremental Retail Cost Parameters}

\begin{tabular}{|c|c|c|}
\hline Prototype & $\begin{array}{l}\text { R-Value } \leq R-22 \\
\$ / f t^{2} / R-V a l u e\end{array}$ & $\begin{array}{l}\text { R-Value }>R-22 \\
\text { \$/ft2/R-Value }\end{array}$ \\
\hline
\end{tabular}

Single-wide and $\quad 0.0249 \quad 0.0265$ double-wide

Table 4.4 shows ECM options selected for the ceiling with characteristics for each option. The "Cost Over Base" column in Table 4.4 is the cost per square feet above the base level of R-11. It is important to note, for manufacturers already producing home models with levels above the base levels, in this case R-11 in the ceiling, the incremental cost of the revised standard would be lower. For example, in the case of ceilings, the most common level reported by manufacturers nationally was $R-19$; therefore, the total incremental cost for these ECMs for most manufacturers would be lower.

\subsubsection{Wall Energy Conservation Measures}

Wall incremental costs were estimated using the costs in the manufacturer surveys. The baseline construction assumption was that the wall studs were $2 \times 4$. With R-19 insulation, $2 \times 6$ studs were assumed to avoid substantial compression of the insulation. 
TABLE 4.4. Ceiling ECM Option Characteristics

\begin{tabular}{|c|c|c|c|c|}
\hline $\begin{array}{c}\text { R-Value } \\
\text { (Nominal) }\end{array}$ & $\begin{array}{c}\text { Cases (a) } \\
\text { In Surveys }\end{array}$ & \multicolumn{2}{|c|}{ U-value } & $\begin{array}{c}\text { Retail Cost } \\
\text { Over Base, } \\
\$ / \mathrm{ft}^{2} \\
\end{array}$ \\
\hline R-11 & 45 & 0.097 & 0.094 & 0.00 \\
\hline$R-14$ & 66 & 0.085 & 0.080 & 0.08 \\
\hline $\mathrm{R}-19$ & 54 & 0.074 & 0.068 & 0.20 \\
\hline$R-21$ & 45 & 0.071 & 0.064 & 0.25 \\
\hline $\mathrm{R}-22$ & 45 & 0.070 & 0.063 & 0.27 \\
\hline$R-28$ & 34 & 0.052 & 0.049 & 0.43 \\
\hline$R-30$ & 66 & 0.051 & 0.047 & 0.49 \\
\hline$R-33$ & 28 & 0.050 & 0.045 & 0.57 \\
\hline$R-38$ & 8 & NA $(b)$ & 0.043 & 0.69 \\
\hline$>R-38$ & 4 & \multicolumn{3}{|c|}{ not included (various R-values) } \\
\hline
\end{tabular}

(a) The number of cases is the number of manufacturers that offer an insulation level. If an insulation level was offered in both singleand double-wide, it was counted as two observations.

(b) Only three manufacturing plants used R-38 insulation in single-wide homes, failing our requirement that at least four manufacturing $p l a n t s$ must use the ECM in current models as reported in our surveys. (Five plants reported using $\mathrm{R}-38$ in double-wide homes ceilings.)

To separate the insulation and construction costs, specific R-value ranges were examined separately. First, to estimate the cost of added insulation without construction changes, cases were examined where the lower and upper R-values were in the range from R-7 to R-14. For a few manufacturers, it was possible that they would change their stud dimensions within this range and the added cost would be reflected in the incremental cost; therefore, the costs were screened and outliers were eliminated (a) including some that appeared to include a change in stud dimensions. Then, the mean cost was calculated for the remaining cases.

This incremental R-value cost calculated from the lower range was used to estimate the cost of only the added insulation in cases where the R-value went from a lower level of R-11 or greater to a higher level of R-19. The

(a) Values beyond two standard deviations of the mean were considered outliers. 
estimated cost over the lower range (involving no construction change) was subtracted from the observed incremental cost over the extended range (presumably including the construction change) and the result provided an estimate of the cost resulting from the change in stud dimensions. The values were then screened (using the two standard deviation criterion) to eliminate outliers (primarily cases where no change in stud dimensions actually had occurred). The mean of remaining values became the estimate of the average structural cost per square foot to change from $2 \times 4$ to $2 \times 6$ studs. Table 4.5 provides the resulting estimates of the wall R-value costs.

\section{TABLE 4.5. Wall ECM Incremental Cost}

\begin{tabular}{|c|c|c|}
\hline Prototype & $\begin{array}{c}\text { Insulation } \\
\$ / \mathrm{ft}^{2} / \mathrm{R}-\mathrm{Val} \text { ue }\end{array}$ & $\begin{array}{c}\text { Structural } \\
\$ / \mathrm{ft}^{2}\end{array}$ \\
\hline Single-wide and double-wide & 0.0386 & 0.167 \\
\hline
\end{tabular}

The incremental insulation costs were about $50 \%$ higher than the values reported by Gates (1988), and in DOE (1986). This difference probably reflected the fact that our estimates were based on actual retail prices rather than manufacturers' construction costs. The estimates of the cost of increasing the stud size were somewhat lower than the $\$ 2.50 /$ perimeter foot estimated by Gates (1988).

Table 4.6 shows the wall ECM options and characteristics for each option. The costs in the column labeled "Cost Over Base" are incremental costs per square feet from the base R-7 level. These are the costs used in the optimization done by ARES.

\subsubsection{Floor Energy Conservation Measures}

The approach used to estimate floor ECM costs was quite similar to that for the other component measures. The incremental cost per square foot per change in R-value was calculated separately for single- and double-wide using all the data collected.(a) The variation of cost with R-value showed no consistent pattern; therefore, the mean value over the entire range was used to estimate the basic incremental cost of adding insulation to the floor.

(a) Outliers more than two standard deviations from the mean were deleted. 
TABLE 4.6. Wall ECM Option Characteristics

\begin{tabular}{|c|c|c|c|}
\hline $\begin{array}{l}\text { R-Value } \\
\text { (Nominal) }\end{array}$ & $\begin{array}{l}\text { Cases In (a) } \\
\text { Surveys (a) }\end{array}$ & U-Value & $\begin{array}{l}\text { Retail Cost } \\
\text { Over Base, } \\
\$ / \mathrm{ft}^{2} \\
\end{array}$ \\
\hline$R-7$ & 65 & 0.114 & 0.00 \\
\hline$R-11$ & 144 & 0.092 & 0.15 \\
\hline$R-13$ & 11 & 0.083 & 0.23 \\
\hline$R-14$ (b) & 19 & 0.086 & 0.27 \\
\hline$R-19$ & 84 & 0.061 & 0.63 \\
\hline$>R-19$ & 10 & \multicolumn{2}{|c|}{$\begin{array}{l}\text { not included } \\
\text { (various R-vatues) }\end{array}$} \\
\hline
\end{tabular}
(a) This counts manufacturers' reports that an insulation level was used in a home model they produced. Single- and double-wide homes were counted separately.
(b) R-14 walls have a higher U-value than R-13 walls because of insulation compression in the R-14 wall, see Appendix B.

Table 4.7 presents the estimates of the incremental cost parameters for floor upgrades. The insulation cost for double-wide homes was about $15 \%$ less per unit area than the value for single-wides. Table 4.8 lists the ECM options and their characteristics.

IABLE 4.7. Floor ECM Incremental cost

\begin{tabular}{lc} 
Prototype & $\begin{array}{c}\text { Insulation } \\
\$ / \mathrm{ft} 2 / \mathrm{R}-\text { Value }\end{array}$ \\
\hline Single-wide & 0.0250 \\
Double-wide & 0.0219
\end{tabular}


TABLE 4.8. Floor ECM Option Characteristics

\begin{tabular}{|c|c|c|c|c|}
\hline \multirow{2}{*}{$\begin{array}{c}\text { R-Value } \\
\text { (Nominal) }\end{array}$} & \multirow{2}{*}{$\begin{array}{l}\text { Cases in } \\
\text { Surveys } \\
\end{array}$} & \multirow[b]{2}{*}{$\underline{\text { U-value }}$} & \multicolumn{2}{|c|}{$\begin{array}{c}\text { Retail Cost } \\
\text { Over Base, } \\
\$ / \mathrm{ft}^{2} \\
\end{array}$} \\
\hline & & & Single & Double \\
\hline$R-7$ & 82 & 0.127 & 0.00 & 0.00 \\
\hline R-11 & 130 & 0.089 & 0.10 & 0.09 \\
\hline R-14 & 44 & 0.073 & 0.17 & 0.15 \\
\hline R-19 & 29 & 0.046 & 0.30 & 0.26 \\
\hline $\mathrm{R}-22$ & 55 & 0.041 & 0.38 & 0.33 \\
\hline$>R-22(a)$ & 4 & $\begin{array}{l}\text { not in } \\
\text { (vario }\end{array}$ & $\begin{array}{l}\text { uded } \\
\text { R-value }\end{array}$ & \\
\hline
\end{tabular}

(a) A sensitivity analysis (section 5.8 ) and BPA programs suggest higher levels of floor insulation are cost-effective compared with other high Rvalue insulations included in this analysis.

\subsubsection{Window Energy Conservation Measures}

Window costs were estimated based on the manufacturer window survey described previously. A regression analys is was performed to separate out the incremental cost for each window characteristic. For the cost analysis, the base level window was assumed to be a single-pane, aluminum-frame window. Triple-pane windows were not offered by any manufacturer and, therefore, were not included in this analysis. The air gap thickness did not have a significant effect on the cost of dual-pane windows.(a) Table 4.9 presents the incremental costs by window characteristic, relative to a single-pane, aluminum-frame window. (b) Manufacturer wholesale costs were multiplied by 1.38 to reflect costs to the buyer (see Section 4.7). (c)

(a) Three window dealers confirmed that air gap by itself was not a significant determinant of price.

(b) The costs were estimated by regressing each characteristic against window price. After deleting outliers, the regression coefficients were significant at the 0.01 level (except the vinyl coefficient, which was significant at about the 0.05 level).

(c) Four window dealers provided cost estimates for vinyl, low-e, and doublepane aluminum windows that were comparable to our estimates. 
Windows could be constructed with any combination of frame type and other features, but certain combinations were predominant in the manufacturer survey. Table 4.10 presents cost and U-value information for the window combinations selected to represent the industry options.

TABLE 4.9. Window Incremental Retail Cost Parameters

\begin{tabular}{lc} 
Feature & Cost, $\$ / \mathrm{ft}^{2}$ \\
\cline { 2 - 3 } Vinyl frame & 2.33 \\
Wood frame & 4.76 \\
Thermal break & 3.02 \\
Dual pane & 4.77 \\
Low-e & 4.47 \\
Tinted glass & 3.27 \\
Storm window & $2.40(\mathrm{a})$
\end{tabular}

TABLE 4.10. Window ECM Option Characteristics

\begin{tabular}{|c|c|c|}
\hline$\frac{U \text {-Value }}{1.20}(\mathrm{~b})$ & $\begin{array}{c}\text { Retail Cost } \\
\text { Over Base } \\
\$ / \mathrm{ft}^{2} \\
0.00\end{array}$ & $\frac{\text { Window Type }}{\text { single-pane, aluminum }}$ \\
\hline 1.20 & 3.27 & single-pane, aluminum, with tint \\
\hline 0.85 & 3.15 & single-pane, aluminum, storm \\
\hline 0.85 & 4.77 & double-pane, aluminum \\
\hline 0.73 & 7.92 & double-pane, aluminum, storm \\
\hline 0.65 & 7.79 & double-pane, aluminum, thermal break \\
\hline 0.51 & 9.53 & double-pane, wood \\
\hline 0.51 & 7.10 & double-pane, vinyl \\
\hline
\end{tabular}

(a) A window lifetime of 30 years was used in ARES. Because the storm window's 1 ifetime was 15 years, $\$ 0.75 / \mathrm{ft}^{2}$ was added to the storm window cost as the discounted cost of the replacement of only the storm window in year 15. Therefore, the incremental storm window cost used in ARES was $\$ 3.15 / \mathrm{ft}^{2}$.

(b) As recommended by ASHRAE, all values are adjusted to a $7.5 \mathrm{mph}$ wind for use in the energy optimization done by ARES. The overall home U-value is expected to be calculated with the $15 \mathrm{mph}$ wind U-value. 
The costs estimated here were compared to those available from other sources. The incremental costs for storm windows and double-pane windows compared reasonably well with DOE (1986). After adjusting for inflation, our estimate of storm window incremental costs was $13 \%$ less than the reference's estimate, and the double-pane cost was $38 \%$ higher. Compared to Gates (1988) our storm window cost estimate was 31\% higher, and our double-pane plus storm window cost was 15\% lower. Compared to DOE (1986), the difference for thermal breaks was larger, $110 \%$ higher in the reference; the difference for wood frames was considerably more, more than six times higher in the reference. Because of the large disparity in wood frame costs, we contacted several window dealers. They indicated that the cost difference between aluminum and wood frames based on our survey results was consistent with their prices, thus supporting our estimates.(a)

\subsubsection{Door Energy Conservation Measures}

The incremental costs of doors were estimated using the survey data and regression analysis.(b) For doors, a set of options that would be expected to affect energy consumption was considered. Based on the surveys, four basic door types were identified: metal, insulated metal, fiberglass, and wood. We had only five observations that included fiberglass doors, with the type of door appearing to vary. Therefore, fiberglass doors were deleted from further consideration. In addition, storm doors were offered by many manufacturers in combination with these basic door types. The base level door was the metal door. The options included insulated thermally-broken metal doors with thermal brakes, wood doors, and combinations of these options with storm doors.

Table 4.11 presents the retail cost of each door option relative to the basic metal door. The results indicated that a storm door cost $\$ 169$ on the

(a) DOE (1986) indicated that wood-framed windows cost about three times as much as aluminum-framed windows with a thermal break. Several window dealers, however, indicated that the wood-framed windows were only about $25 \%$ more expensive than the aluminum windows. Our manufactured home producer window survey did not substantiate the wide price difference suggested by DOE (1986).

(b) Dumny variables were used to identify the door options and the coefficients from the regression indicated the average incremental cost of the options. The coefficients for each of the door options were statistically significant at the 0.01 level. 
average. Based on the data for typical manufactured homes, the median door had an area of $18 \mathrm{ft} 2$, with each home having two doors.

IABLE 4.11. Door ECM Option Characteristics

\begin{tabular}{lcccc} 
Door Type & $\begin{array}{c}\text { Cases in } \\
\text { Surveys }\end{array}$ & & U-Value & $\begin{array}{c}\text { Retail Cost } \\
\text { Over Base, } \\
\text { \$/ft2 }\end{array}$ \\
\cline { 1 - 2 } Metal & 87 & & 0.39 & 0.00 \\
Metal \& storm & NA(a) & 0.28 & 9.39 \\
Metal \& thermal break & 144 & & 0.18 & 7.06 \\
Metal, thermal break \& storm & 181 & & 0.15 & 16.44 \\
Wood & 25 & 0.45 & 14.28 \\
Wood \& storm & 42 & 0.31 & 23.67
\end{tabular}

(a) We did not request data on this combination. Its cost was estimated from the available data, since it is clearly a feasible option.

\subsubsection{HVAC Equipment Energy Conservation Measures}

The use of high efficiency heating and air conditioning (usually referred to as HVAC equipment) is an alternative way to reduce energy use and, therefore, could be a possible ECM option. However, in contrast to higher Rvalue ECMs described previously, higher efficiency space conditioning appliances are not considered here as ECM options for two reasons. First, the congressional report suggests that equipment efficiencies should be treated as fixed, rather than optimized, parameters in the analys is for the standard. It states that "In developing these standards, HUD should assume reasonable levels of ... heating and cooling equipment efficiencies" (CRH 1987). There is no explicit requirement to consider the effect of different equipment efficiency levels in either the law or congressional report. Furthermore, since the congressional report also states that the standard should be specified as an overall U-value, it suggests that the standard should apply to the building's shell and not its equipment. Second, the National Appliance Energy Conservation Act of 1987 (NAECA) (Public Law 100-12, March 17, 1987) sets minimum efficiency standards that will apply to manufactured homes when NAECA goes into effect. Although the NAECA does not limit HUD's authority to 
require a higher equipment efficiency (it does limit state and loca) authority), the NAECA does provide a single appliance efficiency standard for the United States. The NAECA specifically references manufactured homes, setting an efficiency minimum for "furnaces which are designed solely for installation in mobile homes."

Since there is no clear statutory authority to require higher appliance efficiency levels in the new HUD standards, and this area is regulated by the NAECA, appliance efficiency was not optimized in the analysis. Instead, the NAECA minimum appliance efficiencies were used as the levels assumed in the life-cycle cost optimization. The NAECA levels used are shown in Table 4.12.

The law defining the standard revision does impose the requirement that the standard "provide for alternative practices that result in net estimated energy consumption equal to or less than the specified standard" (HCDA 1987). Under this provision, manufactured homes including HVAC equipment more efficient than the required NAECA minimum should be given the appropriate credit. Therefore, the standard will include a method of giving manufacturers credit for HVAC systems which exceed the NAECA requirements(a). This method of giving credit for increased HVAC efficiency will be an adjustment to the

TABLE 4.12. Equipment Efficiencies Used in Life-Cycle Cost Analysis

\section{System}

Electric furnace

Fossil fuel furnace

Heat pump

\section{Efficiency}

$100 \%$

75\% Annual Fuel Utilization Efficiency (AFUE)

6.6 Heating Season Performance Factor (HSPF) with 9.7 Seasonal Energy Efficiency Ratio (SEER)

Air conditioner

9.7 SEER

homes U-value such that the increased U-value allowed will balance the efficiency savings from the increased heating/cooling efficiency. In essence, the manufacturer would be allowed the flexibility, but would not be required, to invest in higher equipment efficiency instead of ECMs in the building's

(a) The NAECA minimum equipment efficiency requirements were assumed in the optimization done to develop the manufactured home standard. 
shell. The adjustment for high efficiency HVAC equipment is described in Section 6.1.

\subsubsection{Infiltration Energy Conservation Measures (a)}

Reduction of air infiltration that also reduces heating and cooling loads is one potential method of lowering energy consumption in manufactured homes. Infiltration-induced heating and cooling load vary with home and climate, but are estimated to account for approximately $20 \%$ to $30 \%$ of the total load in a typical manufactured home. It has been demonstrated that very low infiltration rates are technically feasible in manufactured homes. (b) Because Towered infiltration rates would reduce heating and cooling requirements, infiltration reduction was contemplated as a possible ECM.

No requirement is clearly present in either the legislation or the congressional report to include additional infiltration ECMs in the standard. The congressional report does state, however, that "In developing these standards, HUD should assume reasonable levels of air infiltration" (CRH 1987), which could be interpreted as suggesting that standard revision analysis should assume the infiltration level as a fixed parameter, rather than one that is optimized. The current MHCSS includes several specifications that reduce infiltration, which Congress may have deemed sufficient.

Many manufactured homes in current production are relatively tight. HUD has estimated average air exchange rates to be approximately $0.3 \mathrm{ACH}$ in newly constructed HUD-code homes (Federal Register 1984). A study done for HUD by RADCO (Zieman and Waldman 1984) summarized previous (unreferenced) studies as showing the infiltration rate for new manufactured homes to be about $0.2 \mathrm{ACH}$, and recommended that $0.5 \mathrm{ACH}$ was required to control humidity. (c) In the only study with measured data from a large group of HUD-code homes, BPA estimated
(a) Much of the content of Section 4.6 .9 is a personal communication with Graham Parker, Pacific Northwest Laboratory.
(b) In one BPA demonstration project, five tight HUD-code manufactured homes (ACH) (Lee et al. 1986). (All ACHs in this report were estimated from blower-door tests, followed by applying the Lawrence Berkeley Laboratory's air exchange rate model, producing the natural heating seasonal ACH.)
(c) Hones with the $0.2 \mathrm{ACH}$ reported by RADCO could already have air quality problems unless they are ventilated. 
infiltration rates for 93 multi-wide and 6 single-wide occupied homes built by 18 different manufacturers since 1985 (Ek et al. 1988). The single-wide homes averaged $0.41 \pm 0.16 \mathrm{ACH}$ and the double-wide homes averaged $0.52 \neq 0.16$ ACH. (a) Assuming that the newer homes tested in the BPA study are typical of the manufactured homes currently constructed throughout the country, the air exchange rates of new manufactured homes are in the range of about 0.3 to $0.6 \mathrm{ACH}$. (b) Reductions from this current range that saved significant amounts of energy, for example reducing each homes infiltration rate by one-third, would result in some homes with very low infiltration rates.

Specifying a minimum ventilation rate to mitigate potential health problems in low infiltration homes is difficult, with no generally accepted methods and rates that HUD could apply. Mechanical ventilation can be used to directly exhaust or dilute pollutants at an additional cost. Specifying minimum ventilation rates and the placement of ventilation devices to ensure a minimum ventilation throughout the home may be required. Many indoor pollutants can also be limited by controlling their emissions into the indoor environment (BPA 1987), which is often called "source control"; however, this too might require further study if very low infiltration homes were encouraged.

One factor likely to require mitigation in low infiltration manufactured homes is moisture (Lee 1987). Large amounts of water vapor (humidity) in a home may be harmful to both the occupants and the structure itself (National Research Council [NRC] 1984). Water vapor is particularly difficult to control at the source since the majority of water vapor in homes is generated from normal occupant activity such as cooking, cleaning, bathing, and respiration. Infiltration rate reductions could lead to conditions promoting condensation and could require the addition of mechanical ventilation to reduce the problem. Because moisture problems are complex and not well understood, a determination of both the magnitude of the problem as well as the nature and level of the mitigation efforts would require further study.

\footnotetext{
(a) Double-wide homes had a higher air exchange rate because of leakage along the marriage line and in the crossover ducting. The windows in both sets of homes were also major leakage points.

(b) The infiltration rate presumed in the DOE-2 simulations that underlie ARES is about $0.5 \mathrm{ACH}$, which is representative of current construction.
} 
An added complication in requiring or giving credit for additional infiltration control measures is the practical problems with enforcement. If the standard set a maximum infiltration rate, as opposed to the current prescriptive standard requiring a set of infiltration-reducing measures, then there must be a way to test the rate in a home and an entity responsible for meeting the standard, presumably the manufacturer. A significant problem would be the inability of the manufacturer to control the setup of the home at the site. Setup procedures used to seal the marriage line, connect the crossover ducting, and seal plumbing and electrical connection penetrations can significantly affect air leakage of the home. The actual air exchange rate would be difficult to quantify at the factory before transportation and setup, and might require field testing after setup to verify.

As a further complication, the control and usage of mechanical ventilation equipment by the occupants is uncertain. Some studies have shown that occupants frequently do not use certain types of mechanical ventilation equipment (Drost 1987). These occupants were shown to frequently turn of $f$ their equipment for extended periods of time. The air quality in low infiltration homes where the occupants have turned of $f$ the ventilation equipment could be a significant health risk.

Further study is required before the air quality implications of lowered infiltration homes can be routinely mitigated in a practical, specifiable manner. Although there are significant potential energy savings in reduced infiltration, this reduction must be accompanied by the specification of ventilation measures to mitigate possible resulting air quality problems. A reduction in infiltration levels should be accompanied by 1 ) a clear definition of the minimum ventilation/infiltration rates required for occupant health and moisture control, 2) a practical and economical method for determining the maximum infiltration rate and the minimum ventilation/infiltration rate in commercially produced homes, and 3) a clear definition of the ventilation characteristics other than rates (such as ventilation control and distribution) required to assure a healthy environment in a low infiltration home. It is the authors' opinion that these three elements are not currently available and will require significant additional study by HUD or others prior to 
specifying or giving credit to infiltration control measures beyond those currently in the HUD standard.

\subsubsection{Energy Conservation Measure Lifetime}

The life-cycle cost analysis included the cost of replacing ECMs in the year that they are projected to fail. Table 4.13 shows the ECM lifetimes used in our analysis. Insulation, window, and storm door lifetimes were based on a Minnesota Department of Energy and Economic Development (MDEED 1984) report. (The primary door 1 ifetime was assumed to be equal to the building structural lifetime.) Equipment lifetimes were not needed for this analys is because the equipment efficiencies in the life-cycle cost analysis were fixed.

TABLE 4.13. Energy Conservation Measure Lifetimes

\begin{tabular}{ll}
\multicolumn{1}{c}{ Measure } & Lifetime \\
Insulation & 51 years \\
Windows & 30 years \\
Storm doors \& windows & 15 years
\end{tabular}

\subsection{RETAIL TO WHOLESALE COST MULTIPLIERS}

Two general cost factors that affected the estimates of ECM costs were required; markup from wholesale-to-retail costs and regional ECM cost multipliers.

\subsubsection{Markups}

Markups from wholesale-to-retail were based on manufacturer responses to questions about how much an unspecified conservation upgrade costing them $\$ 1000$ would cost at the wholesale and retail levels. Seventy-nine manufacturers responded with estimates of wholesale costs and 73 responded with estimates of retail costs. Based on national averages, including the effect of an average sales tax of $3.25 \%$ (MHI 1984), the wholesale-to-retail 
markup was estimated at 1.38 (a $38 \%$ markup), which was used here.(a) The MHI (1984) presented a wholesale-to-retail markup of 1.353.

\subsubsection{Regional Cost Multipliers}

The survey data showed some variation in wholesale-to-retail multiplier and regional ECM wholesale costs; therefore, regional variations in costs were estimated. Estimation of regional variation in ECM costs required several steps. For each home type (single- and double-wide) and insulation upgrade option (e.g., R-7 to R-11 wall insulation, R-19 to R-30 ceiling insulation) where five or more cases of the same upgrade occurred in the survey, the mean national wholesale cost was calculated.(b) The calculations of the means were then repeated for each census region. (c) The mean ratio of the regional to national costs became the region's ECM wholesale cost multiplier. In addition, regional markup multipliers were estimated based on the regional differences in the retail markups reported by the manufacturers. The product of the regional ECM cost and regional markup multipliers was the overall regional multiplier.(d) These regional cost multipliers were used in ARES to adjust the ECM costs presented earlier in this chapter.

Table 4.14 shows that the overall cost multipliers were highest in the Northeast. They were the lowest in the West and Midwest. Markups showed less variation than ECM wholesale costs.

(a) Though not used in our analysis, our survey data provided an average multiplier of 1.98 to go from manufacturer's cost (labor plus materials) to retail costs. The MHI (MHI 1984) stated that materials cost constituted $85.1 \%$ and labor constituted $14.9 \%$ of manufacturer's total cost. Based on these data, our estimate of the manufacturer's materialcost-to-retail-cost multiplier was 2.32. The comparable figure reported in MHI (1984) was 2.22.

(b) For each upgrade, observations more than 1.5 standard deviations from the nationai average were deleted.

(c) The Northwest (Washington, Oregon, Montana, Idaho) was split out from the rest of the Western census region.

(d) For the three regions with the largest price variations, the total multipliers were significant at a $90 \%$ confidence level. 
IABLE 4.14. Regional Cost Multipliers

\begin{tabular}{|c|c|c|c|}
\hline Region & $\begin{array}{c}\text { ECM } \\
\text { Multiplier }\end{array}$ & $\begin{array}{c}\text { Markup } \\
\text { Multiplier } \\
\end{array}$ & $\begin{array}{c}\text { Total } \\
\text { Multiplier }\end{array}$ \\
\hline South & 0.99 & 1.00 & 0.99 \\
\hline Northwest & 1.06 & 0.96 & 1.02 \\
\hline West & 0.93 & 1.00 & 0.93 \\
\hline Midwest & 0.95 & 1.00 & 0.95 \\
\hline Northeast & 1.08 & 1.04 & 1.13 \\
\hline
\end{tabular}

\subsection{DUCTS}

Required insulation levels for external ducts were developed in a different manner than the requirements for other components. (a) Duct insulation requirements for the proposed standard were set based on the ANSI/ASHRAE/CABO standard described below.

The ASHRAE (1989 ASHRAE Fundamentals, p. 32.12), the ANSI/ASHRAE Standard 90A-1980, and the Model Energy Code (Council of American Building Officials [CAB0] 1989, 503.9.1) define a criteria for determining a required insulation level. That level is defined as:

$$
R=\Delta T / 15\left(\mathrm{hr} \times{ }^{\circ} \mathrm{F} \times \mathrm{ft}^{2} / \mathrm{Btu}\right)
$$

where $\Delta T$ is the design temperature differential between duct air and duct surface.

To use the formula above, the duct air temperature and the duct exterior surface temperature must be specified. HUD specifies that the air temperature

(a) Optimization of duct insulation is not performed by ARES. A separate duct life-cycle cost andysis of the heating and cooling energy lost in ducts, which would require a detailed model of the duct heat flow and include a model of HVAC system operation, was not readily available. In addition, some of the inputs required for optimization (such as the installed cost and lifetime) were difficult to determine. Duct insulation prices should be available in the future because the BPA and Northwest Power Planning Council are collecting data on duct insulation costs. The National Association of Home Builders has duct insulation costs, although apparently not separately for manufactured homes. 
in the duct should be assumed to be $130^{\circ} \mathrm{F}$ for the purposes of calculating the heat loss ( 32 CFR $3280.509(f)$ ). The winter design temperature (97.5\% values) was taken as the exterior temperature (ASHRAE 1989a, p. 24.4 to 24.15).

Because the standard is applied to zones, specific values had to be determined for each zone. The development of the zones is described in Chapter 5. A two-step process was used to determine a design temperature for each zone. First, a design temperature was developed for each state. Each state's design temperature was the mean of the design temperatures for all cities listed in that state listed by ASHRAE (ASHRAE 1989a, p. 24.4 to 24.15). In the second step, each zone's design temperature was computed as the sales weighted average of the design temperatures of the states making up that zone. (Sales by state are given in Appendix E.) The zone design temperatures were $40,25,19$, and $5^{\circ} \mathrm{F}$ for zones 1 through 4 , respectively. Based on the ASHRAE equation defined above, this translated to the optimum R-values of $6.0,7.0$, 7.4 , and 8.3 for zones 1 through 4 , respectively.

To be consistent with the apparent intent of Congress (see Section 4.1), the choice of insulation was limited to the comnercially available levels of duct insulation. The existing HUD standard requires R-4 insulation on external ducts (24 CFR 3280.715(a)(6) and (7)). Comnercially, duct insulation is available in values of R-4 and R-8. (a) Higher levels are becoming commercially available, but are not yet in general use. Rounding to the nearest available level, the optimum levels become R-4 for zone 1 and R-8 for zones 2,3 , and 4 .

To address practical concerns of insulation compression, this R-value standard should be expressed as a nominal $R$-value installed per insulation manufacturer's specification. It is presumed that the insulation manufacturer's specification would allow only reasonable compression. For example, compression of R-8 insulation into the space previously occupied by R-4 insulation would not comply.

(a) R-8 insulation is currently used comnercially, primarily in some of the northern portions of the U.S., principally the Pacific Northwest. Insulation manufacturers indicate they could easily supply values of duct insulation higher than R-4 to other portions of the country. In the simplest case, insulation of a duct to a nominal R-8 is simply the use of two layers of R-4 insulation. 


\subsection{OPTIMUM U-VALUES AND U-VALUE ZONES}

The statutory requirements for the standard expected that HUD would establish "maximum transmission heat loss coefficients [U-values] in a number of climate zones" (CRH 1987). HUD requirements set overall U-value maximums for the building envelope. The overall U-value (Uo) computation includes the contribution of each building component -- ceilings, walls, floors, and windows -- with the $U$-value $(U)$ of each component weighted by area $(A)$, as shown below.

$$
U_{0}=\frac{(U \times A)_{\text {ceiling }}+(U \times A)_{\text {wall }}+(U \times A)_{\text {floor }}+(U \times A)_{\text {window }}}{\text { total exterior surface area }}
$$

This chapter describes the creation of the U-value zones. This process started with ARES producing separate U-value optimums for each city, fuel/equipment type, and prototype (single- and double-wide). These were aggregated in a series of steps to U-values for four zones in the U.S. Separate U-value requirements were expected for single- and double-wide homes (CRH 1987); however, as discussed below, the requirements for single- and double-wide homes were very similar and, therefore, were merged.

Several other aspects of the production of U-value requirements are also examined in this chapter. The sensitivity of the U-value optimization to several key assumptions is examined. The U-values and zones defined here are compared to other standards. Finally, the incremental costs and benefits for the proposed standard are estimated.

\subsection{INDIVIDUAL LOCAL OPTIMUMS}

Having defined the inputs to the optimization (Chapters 3 and 4), the next step was optimization of ECMs for a large number of cites using ARES. For each city, five combinations of HVAC equipment and fuel were optimized:

- natural gas with a forced air furnace

- LPG with a forced air furnace

- oil with a forced air furnace

- electric resistance with a forced air furnace 
- electric heat pump with forced air distribution.

(All cases assumed electric air conditioning.) The prototypes (single- and double-wide) were optimized separately. The combinations of equipment/fuel types (5) and prototypes (2) resulted in 10 optimizations for each city.

Rather than selecting a few cities to represent the U.S, all 881 cities available in ARES were used. The cities for which optimizations were performed are shown in Figure 5.1, and listed in Appendix C. Selection of all 881 cities included in ARES provides a density of locations such that any point in the U.S. is not substantially separated from a city for which an optimum U-value was produced. The coverage of the U.S. with such a high density of points alleviates any bias that might have resulted from selecting a small number of cities to encompass the large area of the country. The selection of 881 cities, 5 equipment/fuel types, and 2 prototypes resulted in the output of 8,810 cases with specific optimum U-values. (a)

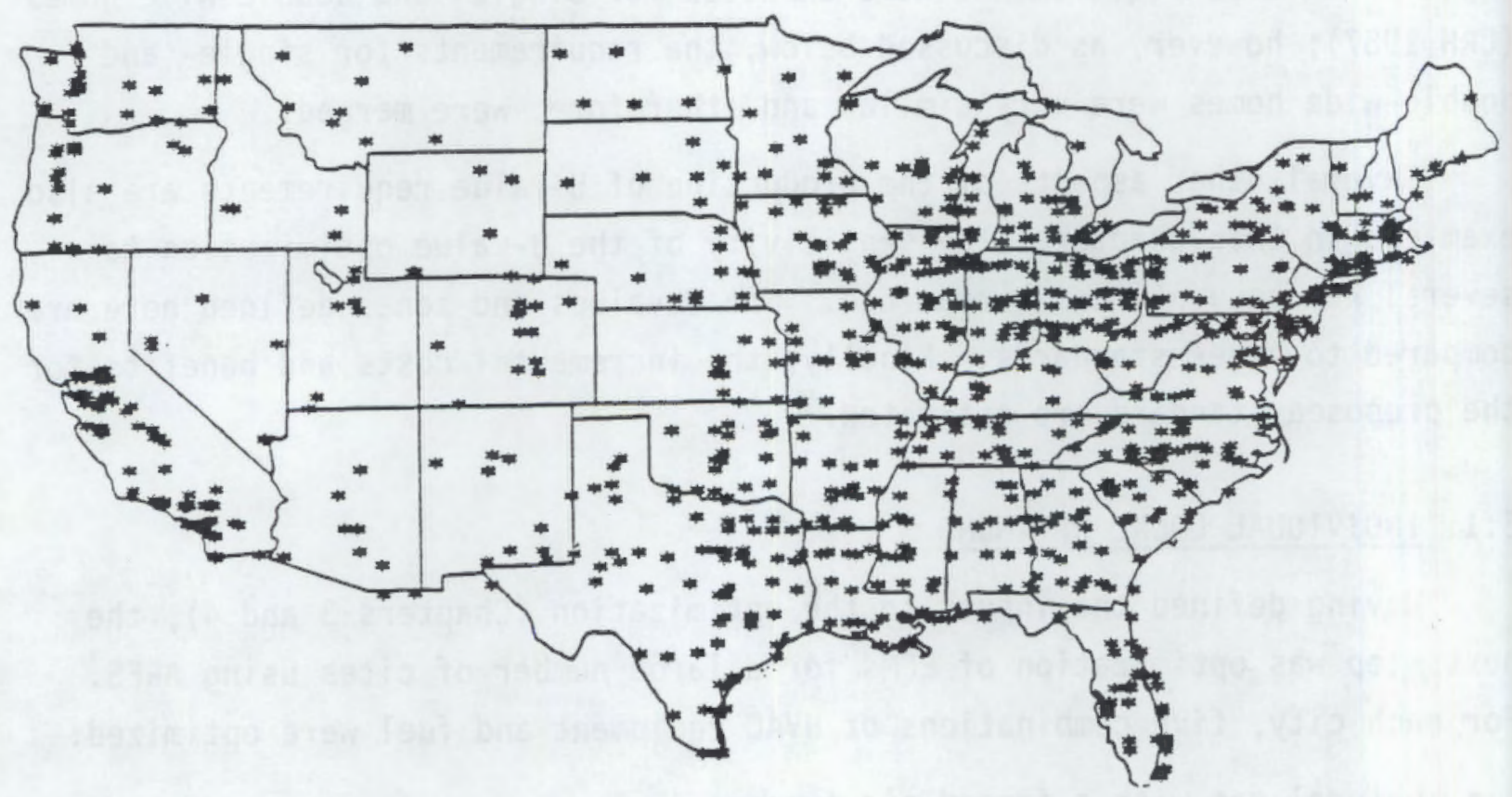

FIGURE 5.1. Cities Used in U-value Optimizations

(a) To facilitate the production of the large number of optimum U-values, software was created to run ARES in a "batch" mode, rather than the interactive mode in which it is usually run. 
The aggregation from the individual $U$-values to $U$-value zones required four $\operatorname{steps}(a)$ :

- aggregation of city U-values into state U-values

- aggregation of single-wide home U-values and double-wide home U-values into U-values for all homes

- aggregation of the separate HVAC equipment and fuel type U-values into U-values for all equipment/fuel types

- aggregation of state U-values into zone U-values.

\subsection{AGGREGATION FROM CITY TO STATE}

The congressional report (CRH 1987) specifies the creation of "climate zones" in which a specific U-value applies. As a practical matter, the standard should define large zones with well-defined boundaries. Therefore, cities must be aggregated into larger zones. Because state boundaries are well defined, the minimum area considered for a U-value zone was a state.

Therefore, all U-value zones were defined as collections of states and the Uvalues defined at the city level needed to be aggregated into state U-values.

The aggregation of city U-values to state $U$-values was done separately for each of the 10 combinations of HVAC equipment, fuel types, and prototypes. In each case, the starting point was the U-values for all 881 cities. The input for this step included a U-value for each city, equipment/fuel type, and prototype. The output for this step included a U-value for each state, equipment/fuel type, and prototype.

The starting point for creating the state U-values was the U-values produced by ARES for each city. The U-values for each state were extrapolated

(a) Optimization of door U-values represented a special case because ARES does not specifically optimize door ECMs. Based on an examination of the cost per unit change in U-value optimums being selected by ARES, it was determined that the base case door with a U-value of 0.39 was optimum across the country. Therefore, this door was assumed in all homes. Because of the small area represented by the door, the effect of this assumption on the home U-value was small. 
from the U-values for the individual cities to the whole area of the state, as described below. The inclusion of the rural as well as urban areas of each state rather than simply using the largest cities, better approximated the distribution of manufactured homes. About two-thirds of the manufactured homes are located in rural areas or small towns (Boeing 1980, p. 56).

The aggregation of cities into states was done in several steps.(a) The initial step was to associate each of the 881 cities' U-values with its location on a U.S. map based on each city's longitude and latitude. Next a 250-by-200 grid of points was laid across the U.S. At each point in the 250by-200 grid, a value was determined by interpolation from the nearby cities. (b) The U-value for each state was then obtained as the average for all points in the grid within that state. This method established a U-value for each state that is resistant to changes caused by the addition or removal of optimum Uvalues for specific cities in that state.(c) In addition, this method gives equal representation to all areas within a state and does not give greater influence to areas with higher population density.

\subsection{AGGREGATION OF SINGLE-WIDE AND DOUBLE-WIDE PROTOTYPES}

The input to this step in the aggregation was the U-values for each state, equipment/fuel type, and prototype. The output for this step was the U-values for each state and equipment/fuel type.

The U-values produced for single-wide homes and double-wide homes were found to be very similar. To test the feasibility of combining the singleand double-wide homes, the U-values for the two prototypes were combined for each state based on a sales weighting of $68 \%$ single-wide U-values and $32 \%$ double-wide U-values (Foremost Insurance Group 1988). The mean difference

(a) All of the processing of the output of the ARES software was done with the statistical-graphics software called "S" (Backer and Chambers 1984).

(b) The " $S$ " function used to do the interpolation was: "interp(city-longitude, city-latitude, city-U-values, 250, 200,0)".

(c) In general, the "geographical mean" U-value described here was very similar to the value that would be obtained from simply taking the mean of the cities in that state. Differences between the mean of the cities in a state and the geographical mean occurred primarily for states with high U-values and large ranges of climate, for instance California and Texas. 
from the combined state U-values was $1 \%$ for single-wides and $2 \%$ for doublewides. At the extreme, the maximum difference in any state from the combined U-value was $2 \%$ for single-wide homes and $4 \%$ for double-wide homes. This difference was deemed to be too small to justify separate U-values for each type of home in the HUD standard. Therefore, the single- and double-wide home $U$-values were combined. The $U$-values by state and fuel/equipment type are listed and shown on maps in Appendix D.

\subsection{AGGREGATION ACROSS EQUIPMENT AND FUEL TYPES}

The input to this step in the aggregation was the $U$-values for each state and equipment/fuel type. This step's output was the U-values for each state.

The retention of separate U-values for each zone, with one for each fuel/equipment type, would make the standard overly complex. Two possibilities were examined: 1) producing separate electric U-values and fossil fuel U-values (with heat pumps probably included in the fossil fuel U-values); and 2) producing a combined U-value that included all equipment types with the overall U-value weighted by the type of heating equipment present in a region.

Simplicity argues for a single U-value for each state. Separate fossil fuel and electric $U$-values would require manufacturers who built both types of homes to build all homes to the lower U-value or maintain two types of homes in inventory, one of which could only have fossil fuel furnaces. A single $U$ value is easier to enforce, because all homes in a region would have the same U-value. In most areas of the country, one type of home (fossil or electric) predominates; the Northwest is primarily electric, the South is over two-thirds fossil, and the rest of the country is primarily fossil fueled (see Table 5.1). Because the combined U-value would be strongly weighted for the predominate fuel/equipment type, the combined $U$-value would also be very close to the $U$-value for the predominate fuel/equipment type.

The primary argument for separate fossil fuel and electric U-values was the accuracy with which the optimum was defined. Separate U-values would have lower U-values for the more expensive electric resistance heat and higher $\mathrm{U}$-values for the less expensive fossil fuels and heat pumps. 
TABLE 5.1. Fuel Types by Region (\%)

\begin{tabular}{|c|c|c|c|c|c|}
\hline & 0i1 & $\begin{array}{l}\text { Nat. } \\
\text { Gas }\end{array}$ & $\underline{\mathrm{LPG}}$ & Elec. & $\begin{array}{l}\text { Heat } \\
\text { Pump }\end{array}$ \\
\hline South & 12 & 27 & 31 & 29 & 1 \\
\hline Northeast & 66 & 23 & 7 & 4 & 0 \\
\hline Midwest & 11 & 49 & 28 & 12 & 0 \\
\hline Northwest & 0 & 5 & 2 & 91 & 2 \\
\hline Southwest & 1 & 65 & 20 & 14 & 0 \\
\hline
\end{tabular}

Based primarily on the simplicity of having a single U-value, the single combined U-value was selected. This is consistent with HUD's current standard and with most other $U$-value based standards which do not differentiate between fuels. The U-value for each state was the weighted average of the equipment and fuel types for the appropriate region, as shown in Table 5.1 and in Figure A.5 of Appendix A. (a) The combined U-values are shown for each state in Figure 5.2 .

\subsection{CREATION OF U-VALUE ZONES}

The input to this step in the aggregation was the U-values for each state. The output for this step was the U-values for each zone.

To create U-value zones, states were grouped based on their similarity in U-values. The goal was to create a small number of zones, which represented the diversity of U-values found in the U.S. The single criteria for definition of the groups was the similarity in U-values. The goal was to group the states such that the difference between each state's U-value and its zone's U-value was minimized, with the constraint that the resulting number of zones be small.

(a) The HVAC equipment and fuel type were taken from the U.S. Oepartment of Commerce (1985) housing survey. The equipment and fuel types for the southwest and northwest were estimated based on this source and Harkreader et al. (1987). 


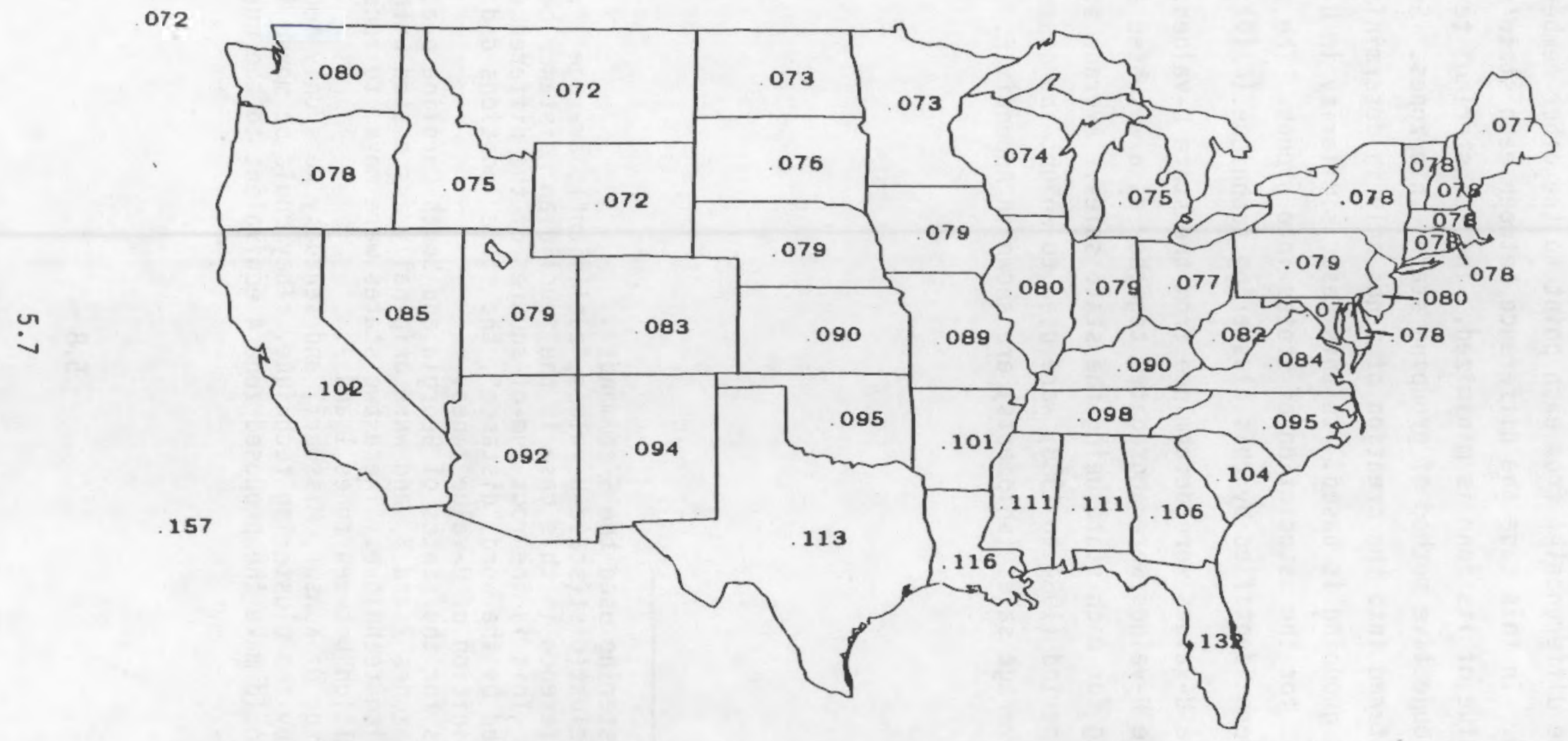

FIGURE 5.2. Optimum U-values by State 
A technique called "hierarchial clustering" was used to group the states (Becker and Chambers 1984).(a) This mathematical technique defines groups such that the difference(b) from each point to the other members of its group is minimized. In this case the difference between each state's optimum U-value and the U-value of its zone is minimized. The "clustering" technique provided a quick and objective method of grouping states into zones. Subjective judgement entered into the creation of zones only in determining the measure on which the grouping is based. In this case, similarity in U-values was the only criteria for the association of states into groups. The zones shown in Figure 5.3 were identified by this clustering technique.(c)(d)

The zone U-values were determined from the state U-values. Within a zone all the state $U$-values were aggregated together as a weighted average, with the weighting for each state being the state sales. Average state sales for a five year period (1984 to 1988) were used to weight the state U-values. The 5-year average sales (shipments) are shown in Appendix E.

(a) The clustering used the $S$ command:

"hclust(dist(state-U-values, "euclidian"), "average") ".

(b) The difference in this case is the "euclidian" distance between the Uvalues. This is the root sum-of-squares of the differences. Although suggested by the word "distance", the state locations did not enter into the definition of U-value zones.

(c) U-values for the states of Georgia and South Carolina placed these states between zones 2 and 3, and were originally associated with zone 3 by the clustering technique. These two states were moved to zone 2 to provide a transition between zones 1 and 3 .

(d) The states of Kansas, Missouri, and Kentucky were only loosely bound to zone 3 by the clustering technique. They could be moved into zone 4, which would make the proposed zone 4 equivalent to the current Title VI zone II. 


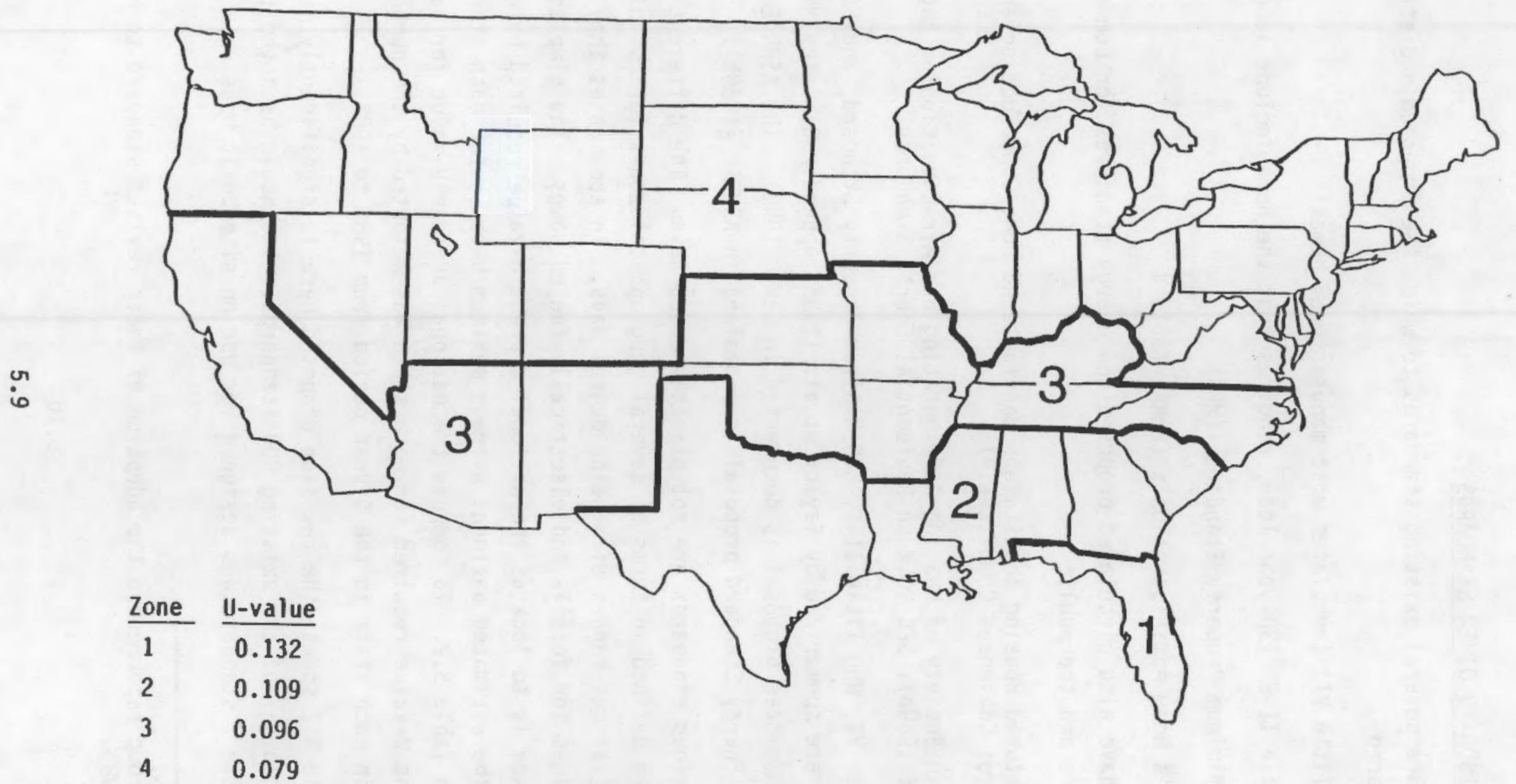

FIGURE 5.3. U-value Zones(a)

(a) Hawaii is zone 1. Alaska is zone 4. 


\subsection{COMPARISON TO OTHER STANDARDS}

There are several existing standards to which the proposed HUD standard can be compared

- HUD's Title VI (regulates most manufactured homes)

- HUD Title II-E (30-year loan, requires that the home include land)

- HUD's Minimum Property Standards (MPS)

- Farmer's Home Administration's (FmHA) Title V

Two groups have also circulated proposed new energy standards for comment by their members and the public

- Manufactured Housing Institute's Manufactured Home Construction and Safety Standards Consensus Committee(a)

- American Society of Heating Refrigerating and Air-Conditioning Engineers (ASHRAE 1989b), SPC 90.2 on Residential Energy Standards.

The HUD Title VI, HUD Title II-E, HUD Minimum Property Standard, and FmHA Title V standards are summarized by Taylor et al. (1988, Appendix B). The MHI Consensus Committee proposal is documented in Levy (1989). The ASHRAE Residential Energy Standard proposal is contained in ASHRAE (1989b).

The various standards are not directly comparable. The different standards are defined in terms of several geographical zones (groups of states) or based on various ranges of heating degree days. In some cases they have separate values for fossil- and electrically-fueled homes. The simplest bas is for comparison is to look at the national average $U$-value required by each standard. The estimated national average maximum $U$-value for each standard is tabulated in Table 5.2. To compute the national average U-value for each standard, the U-value required for each state was weighted by the number of homes sold in each state in the 5-year period from 1984 to 1988.

As Table 5.2 shows, the revision proposed here is significantly more stringent than any of the existing HUD standards. It should be noted that the FmHA Title $V$ standard was designed for use on site-built housing. In

(a) This group recommended the adoption of their revised standard to HUD in June 1989. 
some cases site-built housing can more easily accommodate high levels of insulation; for instance, manufactured home height limitations sometimes constrain the levels of insulation that can be placed in the ceiling. This difference in construction limitations should be considered when comparing a site-built and a manufactured home standard. It is interesting to note that all three recently proposed standards for manufactured homes (those from HUD, MHI, and ASHRAE) in Table 5.2 would require U-values well below the three current HUD standards (Title VI, Title II-E, and MPS). The standard proposed here is closest to that proposed by ASHRAE. If the proposed standard was compared to ASHRAE in terms of energy use instead of U-value, then ASHRAE's proposed standard would be even closer to the standard proposed in the HUD standard.

TABLE 5.2. Average National U-value for Selected Standards

\begin{tabular}{|c|c|}
\hline Average U-value & Standard \\
\hline 0.145 & HUD Title VI \\
\hline 0.125 to $0.140(a)$ & Estimated current practice \\
\hline 0.125 to 0.135 & HUD Minimum Property Standards (b) (c) (d) \\
\hline 0.127 & HUD Title II-E \\
\hline 0.111 & MHI MHCSS Consensus Committee(e) \\
\hline 0.098 & Revision proposed herein \\
\hline 0.092 & ASHRAE $90.2 P$ Residential Standard \\
\hline 0.090 to 0.095 & FmHA Title $V$ \\
\hline
\end{tabular}

(a) National benefits from the standard were estimated in Section 5.7 using this range.

(b) This standard does not require floor insulation in electrically homes under 2500 HDD (heating degree days) or in fossil-fueled homes under $3500 \mathrm{HDD}$. Consequently the U-values for the southern states where large numbers of manufactured homes are built are relatively high.

(c) This standard has a separate U-value for fossil-fueled and electrically-heated homes. These U-values were weighted by the relative number of fossil and electrically heated homes.

(d) MPS and FmHA use a significantly different U-value calculation methodology, in part by not including framing in the U-value. The $U$-values shown here approximate the U-value if framing was included.

(e) Two sets of U-value zones were proposed, one with separate fossil fuel and electric U-values, the other applying to all fuels. The proposal applying to all fuels, as recommended by the MHICC, was used here. 


\subsection{SENSITIVITY OF U-VALUES TO ASSUMPTIONS}

The sensitivity of the U-values to several of the parameters defined in Chapters 3 and 4 was examined with a sensitivity analysis. A sensitivity analysis varies key input parameters and assesses the impact of each. Each parameter was varied separately to determine that parameter's effect on the final U-value optimum.

The sensitivity analysis was done for 10 representative cities(a) with ARES using the single-wide prototype. The average U-value for each variation was computed by giving equal weight to each city and fuel/equipment type. The first column in Table 5.3 identifies the parameter tested. The next two columns show the two values for which a change was determined. The fourth column gives the change in the average $U$-value going from the low value to the high value, with the change expressed as a percentage of the base case average $U$-value. The fifth column is the value selected for this work.

The significance of the parameter selections can be seen from Table 5.3. The down payment and loan term have small effects on the ultimate U-values because the discount rate is close to the mortgage rate and, therefore, the owner is relatively indifferent to when the cost is paid out. The discount rate, which is a measure of the value placed on the future, has a major effect on the $U$-value optimum. The choice of mortgage interest rate also has a significant effect on the U-value. Choosing a site-built rate of $10 \%$, rather than our choice of the manufactured home rate of $14 \%$ would lower the average optimum U-value by about $4 \%$. The choice of inflation rate is very significant, primarily because the mortgage and discount rates are nominal (that is they include inflation) while the fuel price escalation is real. The choice of

(a) The cities were: Key West FL, Brownsville TX, San Diego CA, San Francisco CA, New Orleans LA, Nashville TN, Oklahoma City OK, Seattle WA, Buffalo NY, and Ouluth MN. These cities were selected based on a hierarchical clustering, as described in Section 5.5. Clustering was done on six parameters: heating degree days, cooling degree days, and state fuel prices for oil, gas, LPG, and electricity. HDOs and CDDs (cooling degree days) were weighted $25 \%$ each and each fuel price was weighted $12.5 \%$. Ten clusters were formed containing all 881 cities, and representative cities were selected from each cluster. The overall mean U-value for the base case was . 1095 . 
IABLE 5.3. U-value Sensitivity to Selected Parameters

\begin{tabular}{|c|c|c|c|c|}
\hline \multirow[b]{2}{*}{ Parameter Varied } & \multicolumn{2}{|c|}{ Range } & \multirow{2}{*}{$\begin{array}{l}\text { U-value } \\
\% \text { Change } \\
\end{array}$} & \multirow{2}{*}{$\begin{array}{l}\text { Parameter } \\
\text { Value Selected }\end{array}$} \\
\hline & Low & High & & \\
\hline Down payment & $10 \%$ & $20 \%$ & $0 \%(a)$ & $15 \%$ \\
\hline Loan term, years & 2 & 30 & $+2 \%$ & 14 years \\
\hline Discount rate & $6 \%$ & $22 \%$ & $+20 \%$ & $12 \%(7 \%$ real $)$ \\
\hline Mortgage rate & $10 \%$ & $18 \%$ & $+6 \%$ & $14 \%$ \\
\hline Loan fee & $0 \%$ & $2 \%$ & $0 \%$ & $0 \%$ \\
\hline Points & $0 \%$ & $2 \%$ & $0 \%$ & $2 \%$ \\
\hline Inflation & $0 \%$ & $10 \%$ & $-24 \%$ & $4.9 \%$ \\
\hline ECM costs & $-20 \%$ & $+20 \%$ & $+11 \%$ & costs in Section 4.6 \\
\hline Property tax rate & $0 \%$ & $4 \%$ & $+10 \%$ & $2 \%$ \\
\hline Income tax (deduction) & $0 \%$ & $15 \%$ & $-2 \%$ & no deduction $(0 \%)$ \\
\hline Analysis period, years & 7 & 50 & $-9 \%$ & 33 years \\
\hline Fuel price escalation & $0 \%$ & $5 \%$ & $-13 \%$ & as shown in Table 3.3 \\
\hline Initial fuel prices & $-20 \%$ & $+20 \%$ & $-11 \%$ & as shown in Appendix \\
\hline Minimize lst year's cos & & & $+13 \%$ & life-cycle cost optimum \\
\hline
\end{tabular}

inflation rate calibrates the two sets of rates relative to each other. The choice of loan fee and points makes little difference in the overall U-value. A change in the ECM costs can make an important difference in the optimum Uvalues. Another recent survey of manufacturer's ECM costs (Levy 1989) reported generally lower costs than those reported here. Use of those lower costs would have lowered our optimum U-value. Moving from a $0 \%$ to a $4 \%$ property tax would raise the optimum U-value by $10 \%$. Note that the property tax differs from the loan fees and points in that it is paid annually. For the homeowner who takes the mortgage interest as an income tax deduction, the income tax rate would make a small difference in the optimum U-value; however, this analysis assumes the most common case of the homeowner who does not itemize the deductions on his income tax. The period of analysis has a moderately large impact on the U-value. Increasing the period from 7 years to the 50-year building lifetime would reduce the U-value by $9 \%$. (The building lifetime is required in the congressional report [CRH 1987; CRS 1987]).

(a) A change of $0 \%$ indicates that, to the nearest percent, there was no change. 
Because fuel savings are the major benefit of any investment in conservation, changes in fuel price escalation rates or initial fuel prices have important impacts on the optimum U-value. Finally, using a very conservative criteria for the choice of optimum U-value, the criteria that first year costs should be minimized (not including the down payment) would raise the optimum U-value by $13 \%$.

It is significant to compare the proposed standard with the current HUD Title VI standard, which applies to most manufactured housing. Nationally, the HUD Title VI standard U-values average $48 \%$ above the proposed standard Uvalues (see Table 5.2). Even with the large variations in parameters shown above, there were no changes in optimum $U$-values as large as the difference between the current HUD standard and the proposed standard revision. This strongly supports the argument that the current standard deviates significantly from the optimum, even if relatively large uncertainties in the parameters used in this analysis are assumed. The appropriateness of the proposed standard is further supported by the values proposed (in public review draft) by the Manufactured Housing Institute Consensus Committee (MHICC) and ASHRAE (1989b). The national average U-values for the MHICC and ASHRAE were $13 \%$ above and $6 \%$ below, respectively, the values proposed here.

The sensitivity results reported in Table 5.3 can be used to estimate the impact of other levels or combinations of changes in parameters. Although the sensitivity is not linear with most of the parameters listed in Table 5.3, it often can usually be assumed to be linear for purposes of estimating the impact of a small change.(a)

(a) For example, one might wonder what the impact of constant real fuel prices and a higher discount rate (say $10 \%$ ) would be on the optimum U-value. From Table 3.3, one could estimate a fuel escalation rate of $1.5 \%$ per year was the average rate used here. Assuming the changes in Table 5.3 are linear with the variables examined, a change of $1.5 \%(1.5 \%$ to $0 \%)$ in discount rate would increase the optimum U-value by about $4 \%$. A change of $3 \%(7 \%$ to $10 \%)$ in discount rate would also increase the optimum Uvalue by about $4 \%$. The combination of the two changes would be estimated to increase the optimum U-value by $8 \%$.

A sensitivity analysis of this case was done using the same 10 cities used to create Table 5.3 , assuming the $10 \%$ discount rate and $0 \%$ escalation in real fuel prices. To the nearest $\%$, the result was an 


\subsection{EXTENDED ECMS SENSITIVITY ANALYSIS}

As discussed earlier, the legislative requirement (HCDA 1987) to consider the "factory construction techniques of manufactured homes" was interpreted to require consideration exclusively of ECMs used commercially by a portion of the manufactured home industry. Operationally we translated this legal guideline to the requirement that to include an ECM in our analysis, at least four manufacturers must have reported in our surveys that a specific ECM option was offered in one of their homes. Although consistent with our interpretation of the statutory requirement, the requirement that ECMs be in current commercial use eliminated a number of ECMs that have been demonstrated as currently technically feasible.(a) Current practice, especially in the Pacific Northwest, would show a growing number of manufacturers offering ECM options which include levels above those used as ECM options in this report.

To investigate the impact of including additional ECMs in the analysis, the ARES optimization was performed again for single-wide homes using an extended set of ECM options. (Previous analysis had demonstrated that singleand double-wide homes optimized to similar overall U-values, so only singlewides were used.) Table 5.4 shows the higher level ECM options added for this sensitivity analysis.

Table 5.4 Extended ECMS (b)

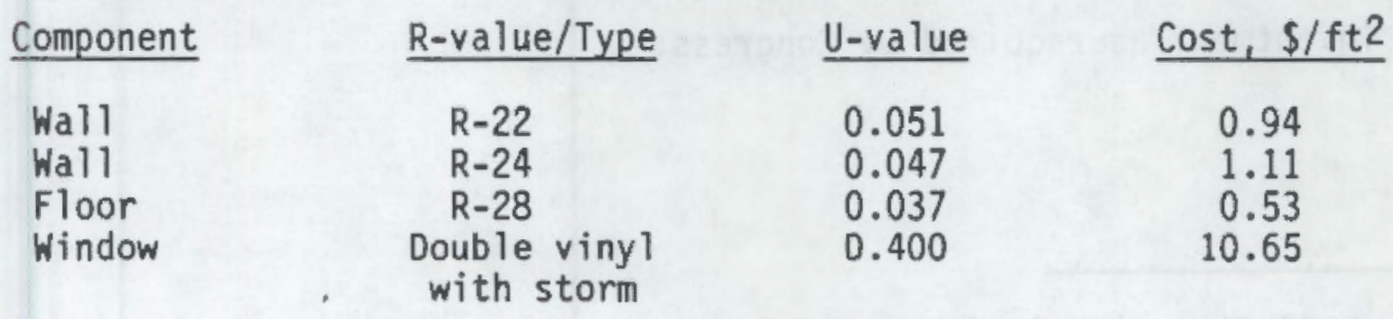

average of an $8 \%$ rise in the optimum U-value.

(a) The survey data demonstrated that a few manufacturers currently offer ECM levels above those assumed in this analysis. In addition, demonstration programs, such as those sponsored by BPA (Onisko 1986; Riewer 1988), demonstrate technical feasibility for additional ECMs.

(b) No new options were added for ceilings, because the highest ECM level in the ceiling ( $R-33$ single-wide, R-38 double-wide) was not selected in the standard analysis (see Figure D.6, page D.6). 
The effect of the new ECM options on the optimum home varied with component. The higher wall ECMs (meant to model an R-19 wall with R-3 and R5 sheathing) were selected only in the very northern states, primarily for electrically-heated homes. The higher R-value for floors was the most commonly selected ECM of those listed above. In the northern states the higher R-value floors were selected for electrically-heated homes and some fossilfueled homes. The new window ECM was seldom selected as optimum. (For the ceilings, there was no effect, as the highest ECM levels used previously were not selected.) The fact that the higher level ECMs were not generally selected in this sensitivity analysis indicates that the ECMs used in generating the standard were generally adequate to characterize the optimum home.

The important measure of the impact of the higher level ECMs on the proposed standard is the effect on the zone U-values requirements. The effect on the proposed U-values for zones 1, 2, and 3 was negligible, because the ECMs were seldom selected as optimum. (a) The effect on the overall U-value requirement for zone 4 was small, less than 0.001 (a decrease of about $1 \%$ of the zone's U-value requirement). (b) We concluded from this sensitivity analysis that the zone U-values were not significantly impacted by including higher ECM levels in the analysis. Therefore, the ECMs included in the analysis defining this standard were adequate to characterize the owners optimum investment as required by Congress.

(a) The R-28 floor insulation was selected as optimum for electrically heated homes in a few zone 3 cities.

(b) One factor lessening the impact of higher levels of R-value on U-values is the relationship of $R$-value to $U$-value. The $U$-value is inversely related to the R-value; therefore, increases of $\mathrm{R}$-value have a diminishing impact on U-value. An example using floors follows. Incrementing the floor insulation from R-7 to R-11 creates an R-value change of R-4 and a floor $U$-value change of 0.038 . (U-values for floors are shown in Table 5.4 and Table 4.8 on page 4.15 .) In contrast, incrementing the floor insulation from $R-22$ to $R-28$ is a larger $R$-value change (R-6), but a much smaller U-value change of only 0.004 . At high R-values, large changes in R-value have only a relatively moderate effect on $U$-value. 


\subsection{DIFFERENCE BETWEEN CITY AND ZONE OPTIMUMS}

The U-value requirements for the proposed standard are presented as overall U-value maximums for four separate zones rather than U-value maximums for each city. (a) The use of zone-specific U-value maximums rather than cityspecific U-values implies that a building in any given city will have a zonespecific maximum $U$-value requirement that will likely not be exactly the city's optimum (minimum life-cycle cost) U-value. This raises the possibility that requiring a building in a specific city to meet a $U$-value that was not the location's exact optimum would significantly raise the life-cycle cost associated with a building in that city. This possibility was investigated as described below.

The relationship between building U-values and life-cycle costs is shown in Figures 5.4 and 5.5. The vertical axis is the total life-cycle cost, including both first costs to install the ECMs (insulation and windows) and the energy costs of the building. The lower the point is on the vertical axis, the lower the life-cycle cost to the homeowner. The horizontal axis is the building U-value. High insulation levels (low U-values/high R-values) will produce points on the left side of the graph. Lower insulation levels will produce points on the right side of the graph. To illustrate how life-cycle costs vary with U-value, the overall U-values and life-cycle costs were calculated for a wide range of possible combinations of ECMs for two cities in different climates. The two cities were Jacksonville, Florida (Figure 5.4) and Washington, D.C. (Figure 5.5).(b)

(a) The use of zone U-values rather than city U-values results in part from the manufactured home industry's strong preference for U-values that are uniform over large areas because individual manufacturing plants may ship homes over large areas. Manufacturers do not want to maintain inventories of homes with a wide variety of U-values. Generally geographically adjacent areas have identical or similar optimum U-values, which facilitates the use of zone based U-values.

(b) Both figures assumed a single-wide home that could have any of the possible ECMs in this report (the ECMs defined in Tables 4.4, 4.6, 4.8, and 5.4). Using all possible combinations of ECMs resulted in 3,024 combinations of ceiling, wall, floor, and window ECMs (8 ceilings, 7 walls, 6 floors, and 9 windows). The 3,024 combinations created a collection of points, the lower bound of which defined the lines on Figures 5.4 and 5.5 showing the least cost for any particular U-value. 


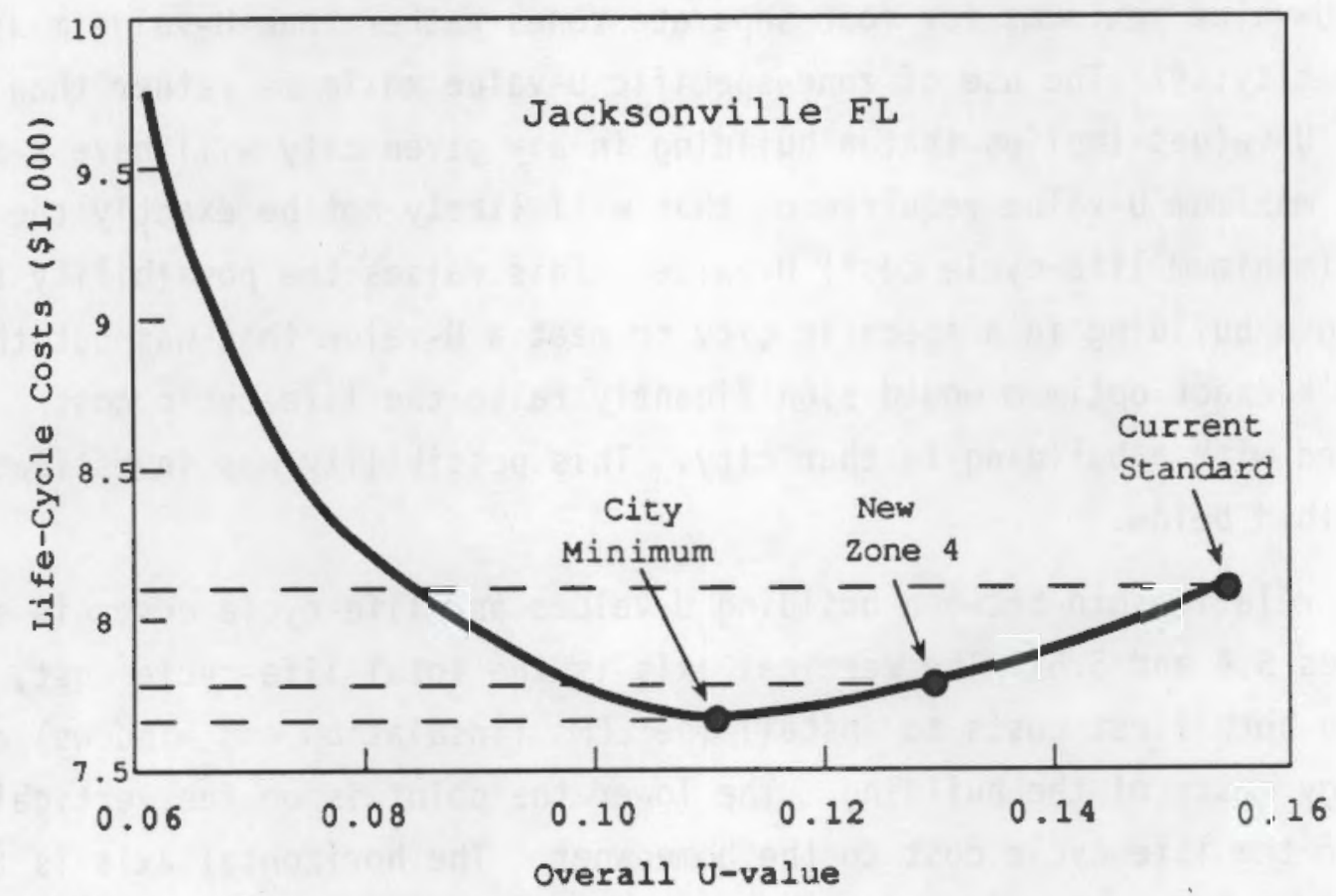

FIGURE 5.4. Relationship Between Life-Cycle Cost and U-value for Jacksonville, Fl.

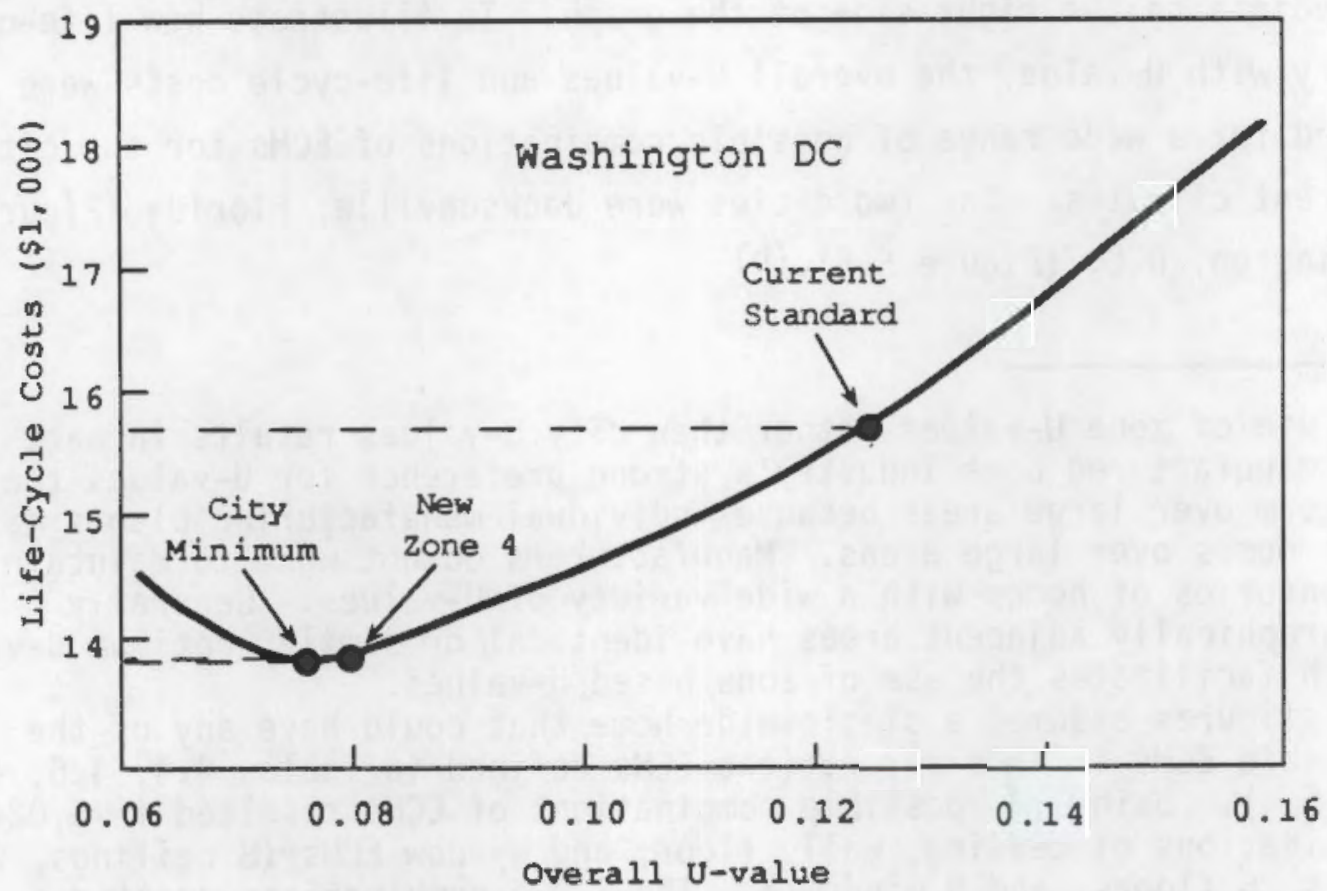

FIGURE 5.5. Relationship Between Life-Cycle Cost and U-value for Washington, D.C. 
The U-value with the lowest life-cycle cost can be seen in the figures. On Figure 5.4, the minimum life-cycle cost for Jacksonville occurs at a Uvalue of about 0.11 . On Figure 5.5 , the minimum life-cycle cost for Washington occurs between a U-value of 0.07 and 0.08 .

Since these figures show the life-cycle costs for a range of U-values, the figures can be used to compare the life-cycle costs at the city's own optimum $\mathrm{U}$-value with the costs at the zone-required U-value to determine the cost increase incurred by the use of zone U-value requirements. For Jacksonville, which is in HUD's proposed zone 1 (Florida), the zone $1 \mathrm{U}$-value requirement is 0.132 . Jacksonville's own optimum $U$-value is lower than the zone $1 \mathrm{U}$-value, reflecting the fact that higher insulation levels are more cost-effective in Jacksonville's climate than the milder climates in most of the rest of zone 1. Therefore, the $U$-value that represents the lowest life-cycle costs for Jacksonville is below the zone 1 average U-value. From Figure 5.4 it can be seen that the life-cycle costs are fairly constant in the $U$-value range near Jacksonville's optimum (minimum life-cycle cost). The life-cycle costs for a building built to the zone requirement of 0.132 are near the life-cycle costs for a building built to the city's optimum at about 0.11 . The difference in life-cycle cost for Jacksonville's minimum and the zone minimum is about $\$ 100$ over the building's lifetime.

For Washington, D.C. (Figure 5.5), the city's life-cycle costs are relatively flat near the city's optimum; flat enough that it is difficult to read the exact point at which the optimum occurs. The difference between the city's own optimum life-cycle cost and the zone 4 requirement $(0.079)$ for washington, D.C. is very small. (The difference in life-cycle cost between Washington, D.C.'s minimum and the zone minimum is less than $\$ 100$ over the building's lifetime.)

The conclusion that life-cycle costs of U-values near the individual city's optimum U-value are similar to the zone optimum can be generalized to all other cities. Stated another way, the life-cycle cost curve is always flat near the minimum. Therefore, the impact on the life-cycle cost resulting from using zone $U$-values instead of city U-values is small.

It is instructive to compare the life-cycle costs associated with the existing standard with those that are optimum for the two cities. For

\subsection{9}


Jacksonville, a home built to the existing HUD standard of 0.157 rather than the proposed HUD standard would cost its owners about $\$ 400$ more over its lifetime. For Washington, D.C., the existing requirement of 0.126 adds almost $\$ 2000$ in costs over the home's lifetime. For most U.S. cities, the proposed zone U-values are significantly closer to the city's optimum than the existing HUD U-value standard. The average national life-cycle cost savings to the home's occupants from the proposed standard is about $\$ 2000$.

\subsection{LIFE-CYCLE SAVINGS, MORTGAGE COSTS, AND ENERGY SAVINGS}

The next section compares the costs and benefits from the consumers' perspective for the current practice, the existing HUD Title VI standard, and the proposed standard. This is followed by an estimation of the total national present value of the proposed standard compared to current practice. Finally the R-values required by the proposed standard and Title VI are compared.

\subsubsection{Comparison of the Proposed Standard to Current Practice}

The approximate costs and benefits of the proposed standard were compared to current practice. The average current practice home has a U-value somewhat less than the Title VI requirements because a significant number of new homes are built with U-values at least slightly below the Title VI maximum. Based on home manufacturers' reports of their most commonly produced model, the mean current practice new home in the U.S. was approximated as a home with a $U$-value between 0.140 and 0.125 . The average additional cost per currentpractice home to meet the proposed standard would be in the range of $\$ 800$ to $\$ 1100$. The average present value of the energy savings would usually be 2 to 2.5 times the cost of meeting the standard.

The aggregate national net value (costs minus benefits) of the proposed standard above the current practice was estimated. The net savings for the homes built each year would be about $\$ 20 \mathrm{M} /$ year(a), continuing for the lifetime of the homes. The total national savings would be about $\$ 20 \mathrm{M}$ in the first year, $\$ 40 \mathrm{M}$ in the second year (\$20M from the first year's homes plus \$20M from the second year's homes), \$60M in the third year, and so on. Nationally, savings would continue to increase each year as energy efficient manufactured

(a) This is based on a production of about 200,000 homes per year. 
homes meeting the proposed standard became a higher fraction of the housing stock.

Since the benefits of the standard (reduced energy costs), occur over the lifetime of the homes, computing the annual national aggregate value of the standard requires taking the net present value of the costs and benefits for homes. This calculation sums the present value of the energy savings and deducts the present value of the costs over the lifetime of the homes produced each year. These savings are built into the construction of the homes (in the form of insulation) as they are built. The net present value of the proposed standard is estimated to be $\$ 300 \mathrm{million}$ per year. (This value would be about $\$ 400$ million per year if all homes were assumed to be built to the Title VI standard.)

\subsubsection{Comparison of the Proposed Standard to the Title VI Standard}

The cost and benefits of the proposed standard, relative to the Title VI standard, are displayed in a series of figures below. The proposed standard and the Title VI standard are compared in terms of mortgage costs, energy costs, and the net costs. The proposed standard always increases costs to buy the new ECMS and decreases costs for energy. The net present value from the consumer's perspective is the difference between the increased ECM costs and the decreased energy costs.

The first two figures show the increase in costs resulting from the purchase of additional ECMs required by the proposed standard. Figure 5.6 displays the increase in monthly mortgage payment. The national average (sales-weighted) increase in the mortgage payment was $\$ 10 /$ month. Note that after 14 years, the mortgage is paid off while the energy savings continue. Figure 5.7 shows the present value of the incremental costs (primarily the mortgage and financing costs) of the standard. The average cost for upgrading a home from Title VI was about $\$ 1200$.

The next two figures present the benefit of the proposed standard, the energy savings. Figure 5.8 shows the monthly savings by state. Nationally the first year savings in energy costs averaged $\$ 18 /$ month, which slowly escalates over the home lifetime. Note that the monthly savings in energy 


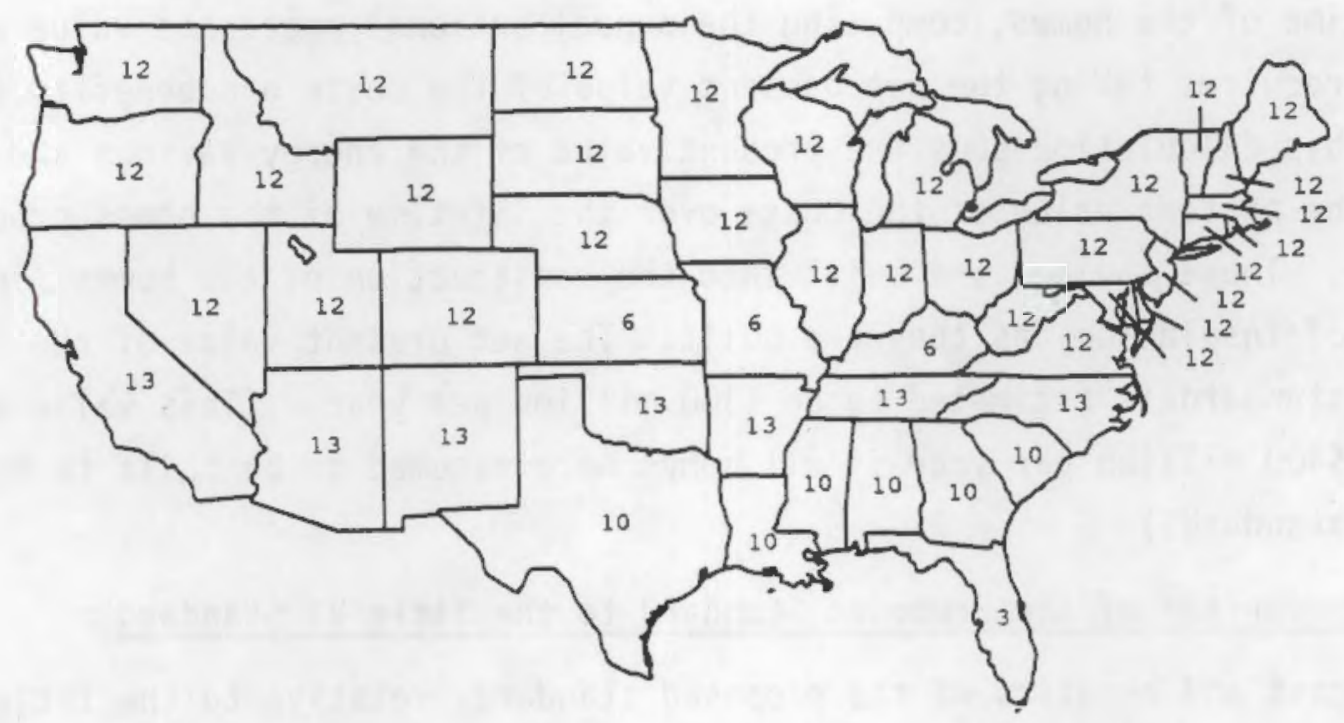

FIGURE 5.6. Monthly Mortgage Payment Increase for Proposed Standard ( $\$ /$ month)

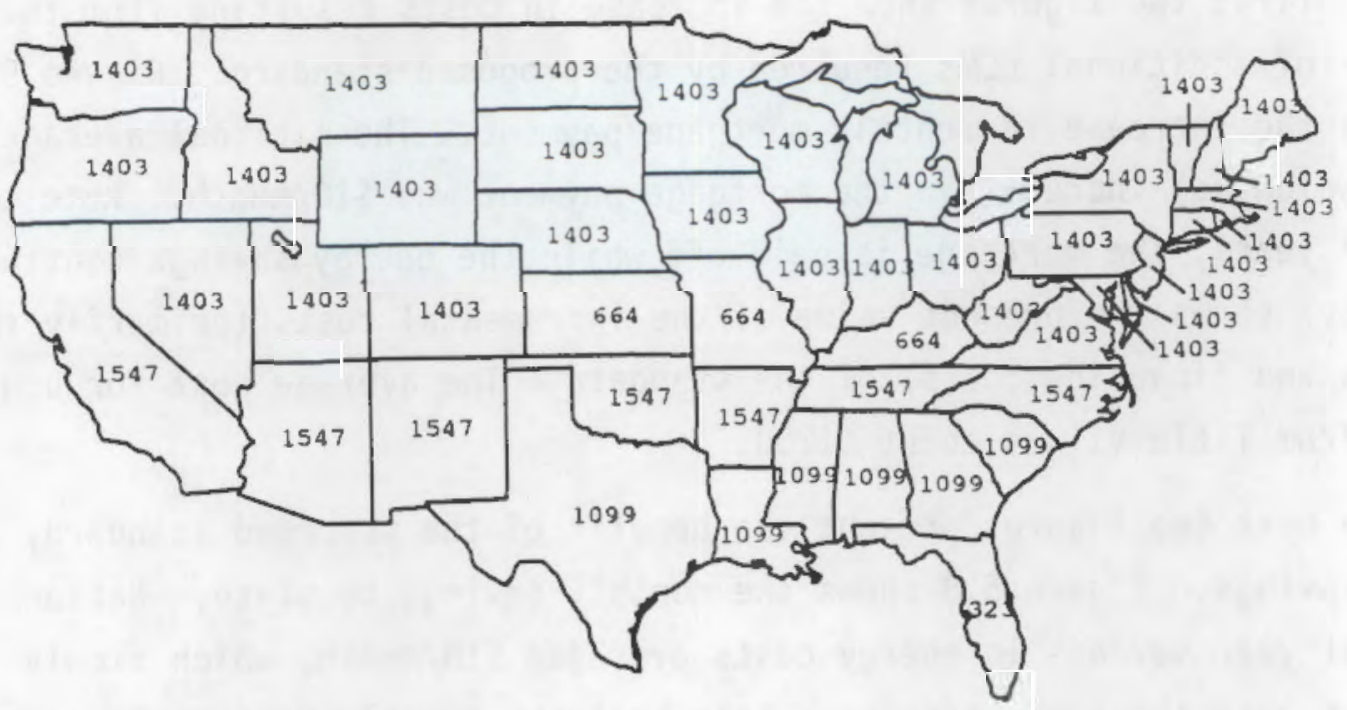

FIGURE 5.7. Present Value of Cost Increase for Proposed Standard (\$) 


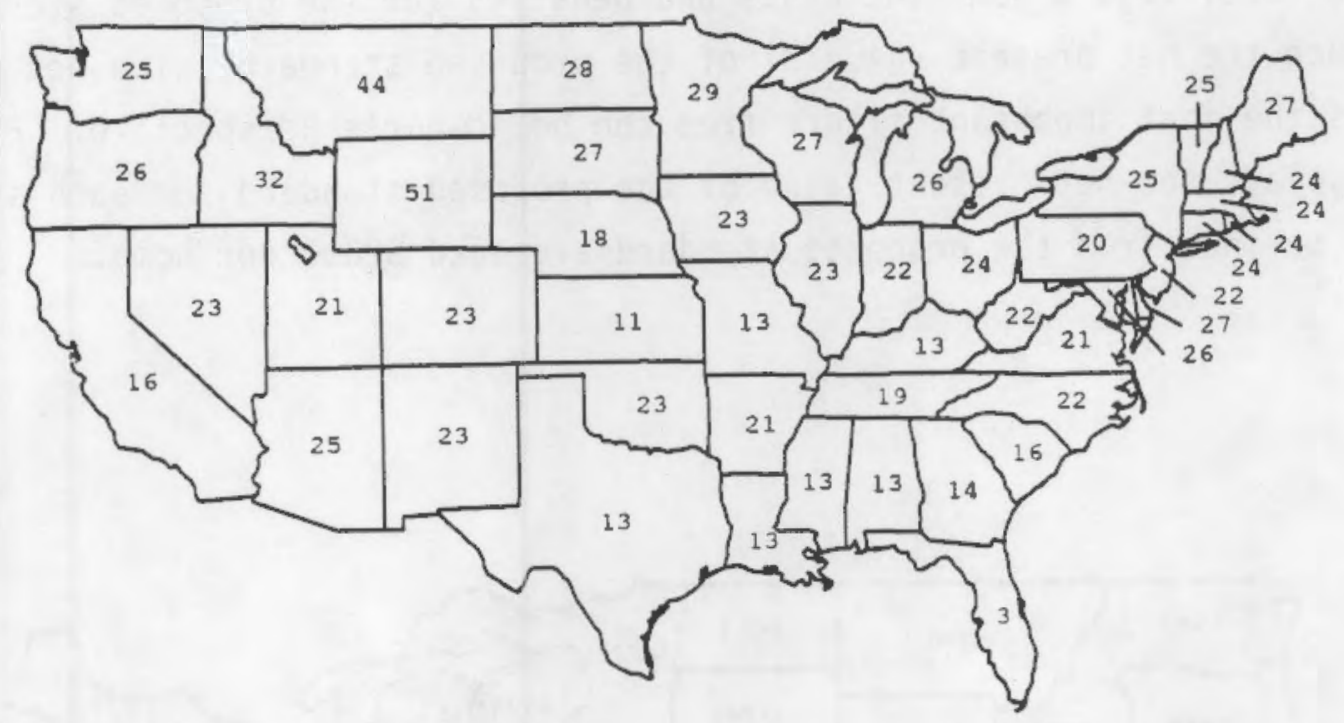

FIGURE 5.8. Monthly Energy Cost Decrease for the Proposed Standard (\$/month)

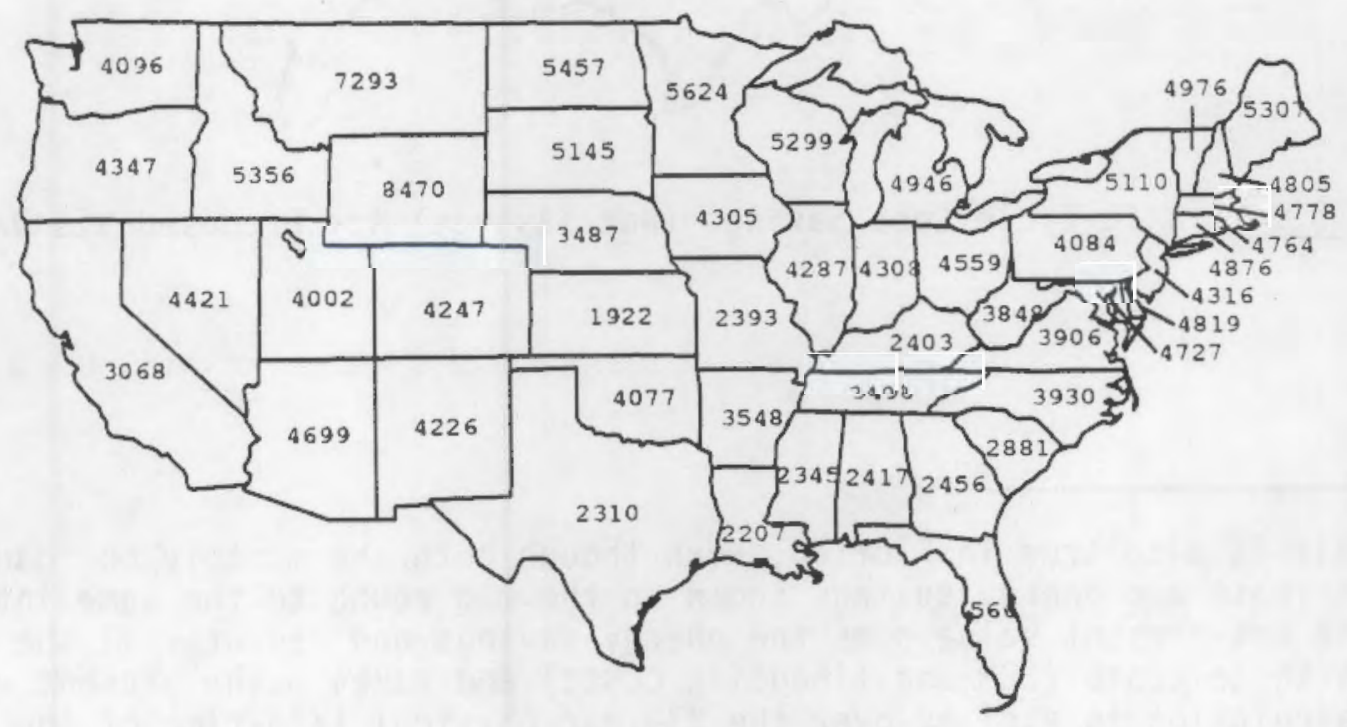

FIGURE 5.9. Present Value of Energy Savings for Proposed Standard (\$) 
costs exceeds the monthly mortgage payment increase in all states(a), as shown in Figures 5.6 and 5.8. Figure 5.9 shows the present value of the energy savings by state. The present value of the energy savings averaged $\$ 3200$.

The final figure sums the costs and benefits for the proposed standard, to produce the net present value(b) of the proposed standard. The net present value is the most important figure from the homeowner's perspective. Figure 5.10 displays the net present value of the proposed standard for each state. The net savings from the proposed standard averaged $\$ 2000$ per home.

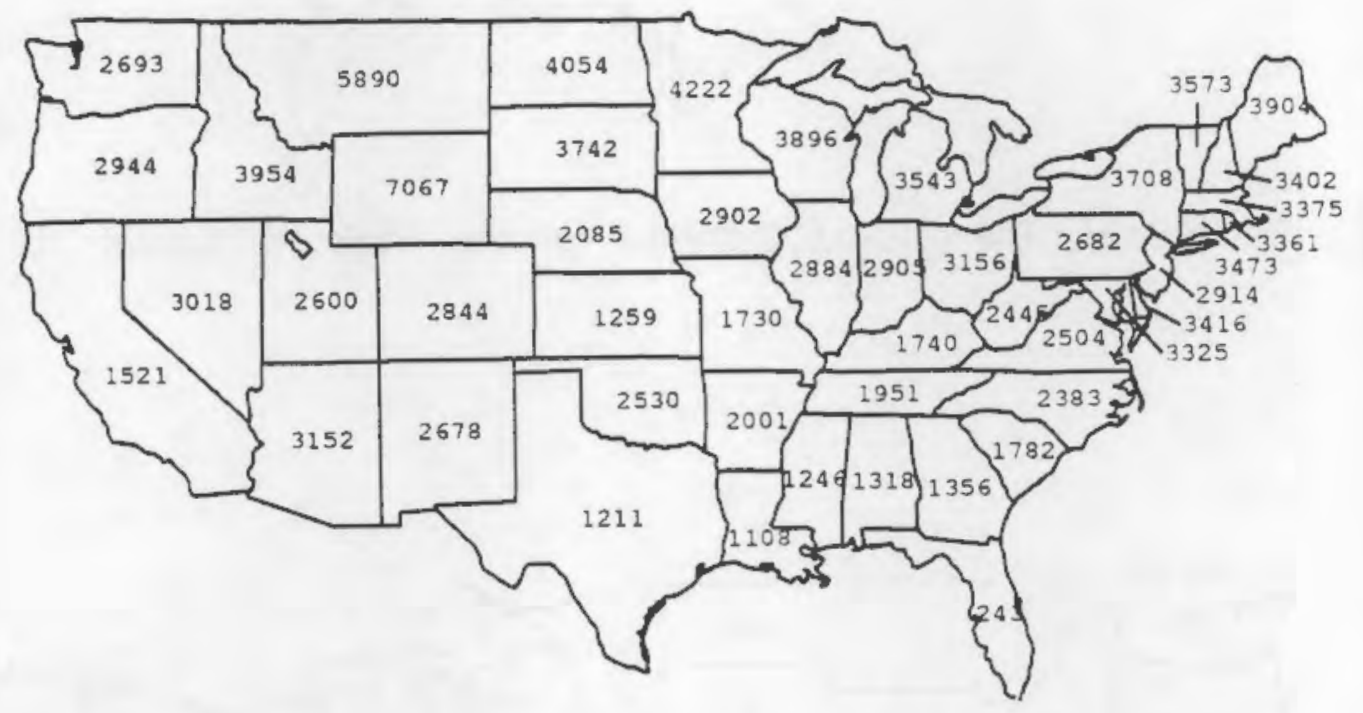

FIGURE 5.10. Life-Cycle Cost Savings (Net Savings) for Proposed Standard (\$)

(a) This is also true in Florida, even though both the monthly mortgage cost increase and energy savings shown on the map round to the same integer.

(b) The net present value sums the energy savings and deducts all the mortgage costs (ECM and financing costs) and taxes. The present value calculation is applied over the 33-year physical life-time of the building with future dollars discounted. 


\subsubsection{Comparison of R-values for Proposed Standard and Title VI}

The insulation R-values currently required by Title VI and the insulation $\mathrm{R}$-values that would meet proposed requirements can be compared. In general, a home with R-11 in the ceiling, R-7 in the walls, R-7 in the floor, and single-glazed windows would meet the Title VI zone I standards. A home with R-14 in the ceiling, $R-11$ in the walls, R-7 in the floors, and single glazing with a storm window would meet the HUD Title VI zone II standards.

The standard prescribes only the overall maximum U-value, not the specific R-values by component. However, the insulation levels in each of the four new zones can be approximated. In zone I (Florida, with $11 \%$ of the U.S. sales), a home with R-14 in the ceiling, R-11 in the walls, R-11 in the floors, and single glazing would often meet the new requirements. For zone II (about $28 \%$ of sales), R-19 ceilings, R-14 walls, R-14 floors, and single-pane glazing with storm windows would often meet the new code. In zone III ( $29 \%$ of sales), R-22 ceilings, R-14 walls, R-19 floors, and storm windows would be close to the minimum U-value. For the proposed standard's zone IV ( $31 \%$ of sales), R-22 ceilings, R-19 walls, R-19 floors, and double-pane vinyl or wood windows would usually meet the standard. Note these values are for illustration only. Other ECM combinations would also meet the standards. The R-values required for a specific home are dependent on the home design and construction and are particularly sensitive to the window area.

\subsubsection{Social Benefits of the Revised Standard}

There are a number of significant social benefits from the standard that are not reflected in the net present value ( $\$ 300$ million per year) of the revised standard relative to the current practice. These benefits result from positive impacts of the standard that are external to the market valuation of manufactured home energy efficiency from the consumers perspective. Several of these factors external to the market, called "externalities" by economists, are discussed in Appendix G. For example, the market does not properly value the high marginal cost of the new utility generation/distribution construction that would be necessary if not for the more energy-efficient manufactured homes. Also, the use of average energy prices in the residential energy market underestimates the higher than average capacity costs associated with heating and cooling loads. Appendix $\mathrm{H}$ estimates 
a value for one major externality to the energy market, the environmental impact of energy use. This environmental impact includes the emission of $\mathrm{SO}_{2}, \mathrm{NO}_{\mathrm{x}}$, and particulates during the generation of electricity and the burning of fossil fuels. Although these "environmental externalities" are difficult to value, they are clearly large. Based on Appendix $H$, the present value of the revised standard resulting from the reduction in environmental impact from the emission of $\mathrm{SO}_{2}, \mathrm{NO}_{\mathrm{x}}$, and particulates is estimated to be $\$ 50$ million to $\$ 160$ million per year. (a) These positive social impacts of the revised standard were not included in the optimization that developed the revised standard, but they are clearly significant national benefits of the standard. (b)

(a) Not including a value for $\mathrm{CO}_{2}$.

(b) Appendix I details annual costs and benefits from the social and consumer's perspective for four homes. This appendix also illustrates the tradeoff between ECM costs and energy savings using four homes with a large variation in U-values. 


\subsection{ALTERNATIVE METHODS OF COMPLIANCE}

Two alternative methods of compliance are suggested for inclusion in the standard. These methods "provide for alternative practices which result in net estimated energy consumption equal or less than the specified standard." (HCDA 1987). The first alternative method allows a trade-off between U-value and HVAC efficiency. The second alternative allows a calculation or simulation of energy use to show that a home meets the energy use implicit in the U-value standard. The characteristics of an acceptable calculation are also suggested. Although a calculation could be used with any home, it requires significantly more effort and is intended only for use with innovative designs that are not adequately characterized by a U-value.

\subsection{EQUIPMENT EFFICIENCY ADJUSTMENT}

One method of improving the energy performance of the home is to use HVAC efficiencies higher than those required by NAECA. Complying with the requirements for the new standard (CRH 1987), these homes with high efficiency HVAC equipment will be allowed a higher U-value for purposes of meeting the U-value standard. The development of the alternative method to account for higher HVAC efficiency and an example of its use are given in Appendix F.

\subsection{CALCULATION/SIMULATION ALTERNATIVE}

In general, the energy-based criteria is intended to allow any home which meets the maximum annual energy use implicit in the U-value standard to be acceptable under that standard. This requirement was presumably targeted at homes with innovative designs, where the level of energy consumption is not adequately characterized by a U-value based standard. For example, "passive solar" homes may have moderately high U-values because of large window areas, but may also have lower annual energy use than more conventional homes with substantially lower U-values.

A requirement for compliance under this alternative is the demonstration that a home's energy use is less than or equal to a similar home that would comply with the standard. This demonstration must be based on "generally accepted engineering practices" to ensure that the calculation or simulation 
of annual energy use is credible. The general characteristics of the acceptable engineering practices and several assumptions that should be made are suggested here, although it is not anticipated that this list will be included in the standard text. The goal in defining the acceptable engineering practices and required assumptions is to assure a reasonable approximation of the home's energy use and allow a valid comparison between a home whose energy use can be characterized by $i t s \mathrm{U}$-value and an innovative home whose energy use is not characterized by its U-value.

The general requirement is to demonstrate that the home to be approved has a projected annual energy use, including both heating and cooling, less than or equal to a similar "base case" home that meets the standard. The annual energy use in the two homes must be compared based on accepted engineering practices using a consistent set of assumptions. To be a reasonable comparison, both homes must have the same dimensions for all boundaries between conditioned and unconditioned spaces. Both homes' annual energy use must be calculated based on the same assumptions, including assuming the same site characteristics and usage patterns. The annual energy use determination could be based on a calculation and/or a computer simulation. The request for compliance approval under this alternative should be accompanied by documentation of the annual energy analysis demonstrating compliance. It should be noted that this alternative is not intended to allow any conditions that might endanger the occupants' health, such as low infiltration homes without adequate ventilation.

We suggest that the following should be accounted for in the annual energy use calculation.

- The impact of internal heat gains generated by occupant activity on heating and cooling loads should be specifically accounted for. Internal gains should be assumed to be $60,000 \mathrm{Btu} /$ day. (a)

- The impact of solar gains on heating and cooling loads should be specifically accounted for in the calculation.

(a) This is in the range of the commonly assumed internal gains (ASHRAE 1989a, p. 28.4) Other values near this value are acceptable, but the assumptions need to be specified. 
- Coincident exterior temperature data and solar insolation data should be used to determine the annual energy use. The weather data should be representative of the general location of the sited homes, if known. At a minimum, the weather data should be from the U-value zone for which the home is to be approved.

- The calculation should represent the seasonal variation in the weather by using at minimum 1 day for every month.

- The energy used by any ventilation system not common to both buildings should be specifically accounted for and included in the annual energy use estimates. (a)

We suggest that the following assumptions should be made:

- The thermostat setpoints should be a constant $70^{\circ} \mathrm{F}$ for heating and a constant $78^{\circ} \mathrm{F}$ for cooling.

- Both homes should assume the same type of HVAC systems and fuels, both of which must comply with NAECA requirements. A manufacturer seeking approval for a home may assume a higher efficiency, if such a system will be installed in that home.

- For mixed fossil and electric systems, the electricity should be equated to the fossil fuels at the rate of 1 kwh per 3413 Btus.

- The home orientation the axis on which the length of the home runs, should be $45^{\circ}$ east of north. (b) If known, then the actual orientation of the home may be used.

(a) This anticipates low infiltration homes requiring additional ventilation.

(b) This orientation represents a "mean" orientation for window solar loads (gains). Without specification of the orientation, all large window areas could be assumed to face south and would be calculated to perform more favorably than the mean performance of all possible orientations. Homes for which the site is not known are best represented by this "mean" orientation. 


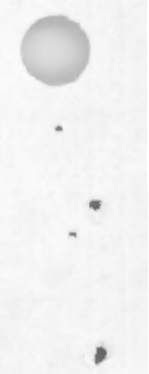




\subsection{PROPOSED STANDARD TEXT}

Based on the contents of this report, the following is recommended as the revision to the text in Section "§ 3280.506 " of the Manufactured Home Construction and Safety Standards. (The specific division into subsections shown here is only for clarity.)

(a) Overall Thermal Transmittance. The calculated overall thermal transmittance (Uo) of the manufactured home shall not exceed the values listed below (as shown in Figure 7.1):

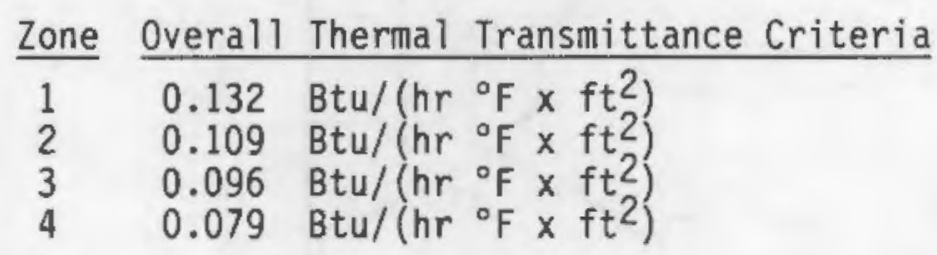

Calculation of the Uo shall be consistent with the HUD's Manual "Overall U-values and Heating/Cooling Loads- Manufactured Homes" or the equivalent. Areas where the insulation does not fully cover a surface or is compressed shall be accounted for in the vo calculation.(a). The effect of framing on the U-value must be included in the Uo calculation. Other low-R-value heatflow paths ("thermal shorts") shall be explicitly accounted for in the calculation of the transmission heat loss coefficient if, in the aggregate, all types of low-R-value paths (b) equal more than $1 \%$ of the total exterior surface area. Areas are considered low-R-value heat flow paths if 1) they separate conditioned and unconditioned spaces and 2) they are not insulated to a level that is at least one-half the predominate nominal insulation level of the surrounding building component.

(b) To assure uniform heat transmission in manufactured homes, cavities in exterior walls, floors, and ceilings shall be provided with thermal insulation. (c)

(a) The ASHRAE 1989 Fundamentals Handbook states "Relatively small conductive elements within an insulating layer ... can substantially reduce the average thermal resistance of a component." (ASHRAE 1989a, p. 22.2). (Footnotes are not intended to be part of the text of the standard.)

(b) A more specific list of the types of possible thermal shorts should be provided separately from the standard text.

(c) This is no change from the current text. 


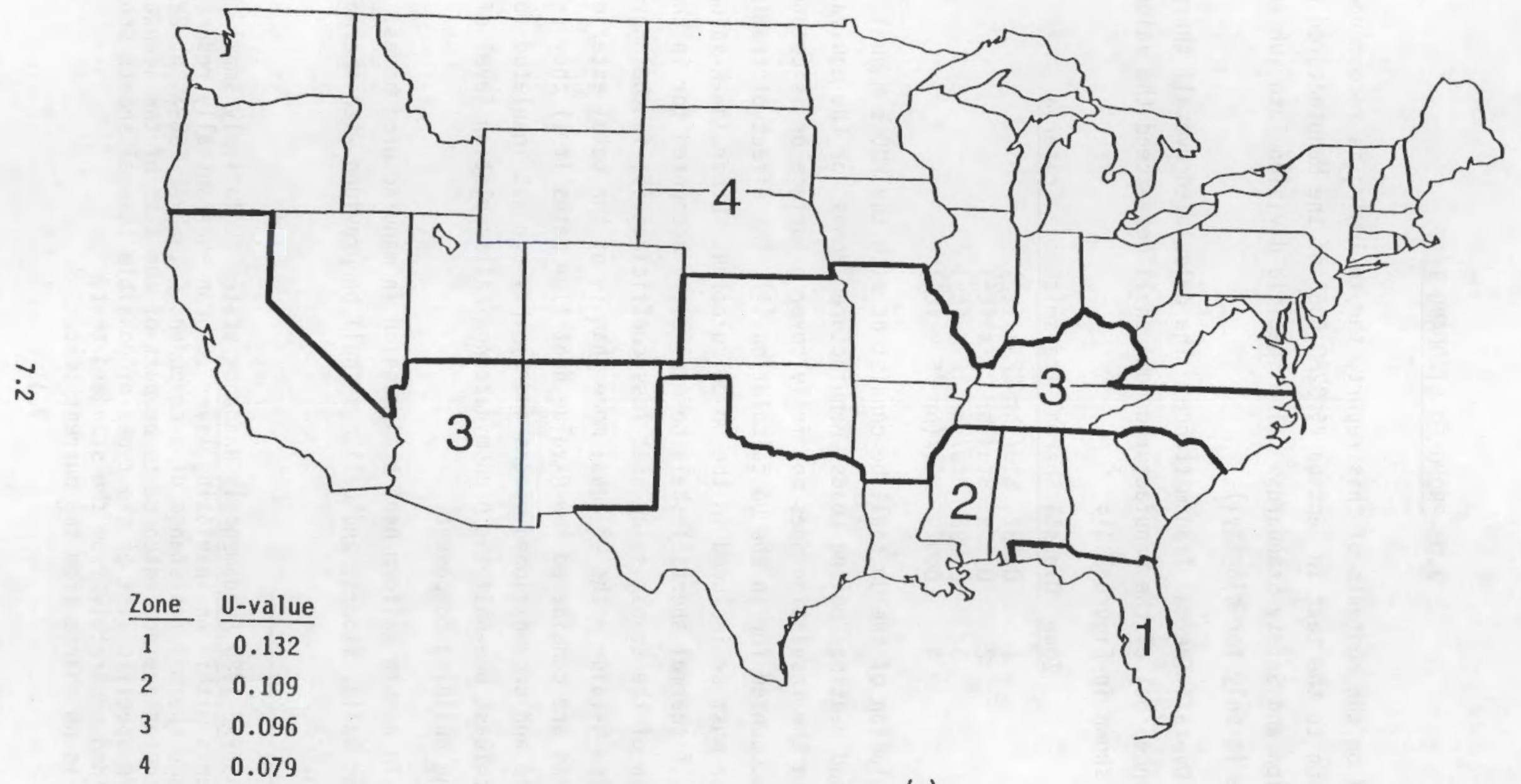

FIGURE 7.1. U-value Zones (a)

(a) Hawai i is zone 1. Alaska is zone 4. 
(c) High Efficiency Heating and Cooling Equipment Credit. The calculated transmission heat loss coefficient (Uo) used for meeting the requirement in $\$ 3280.506$ (a) may be adjusted for heating and cooling equipment efficiency above that required by the National Appliance Energy Conservation Act of 1987 (NAECA) by applying the following formula:

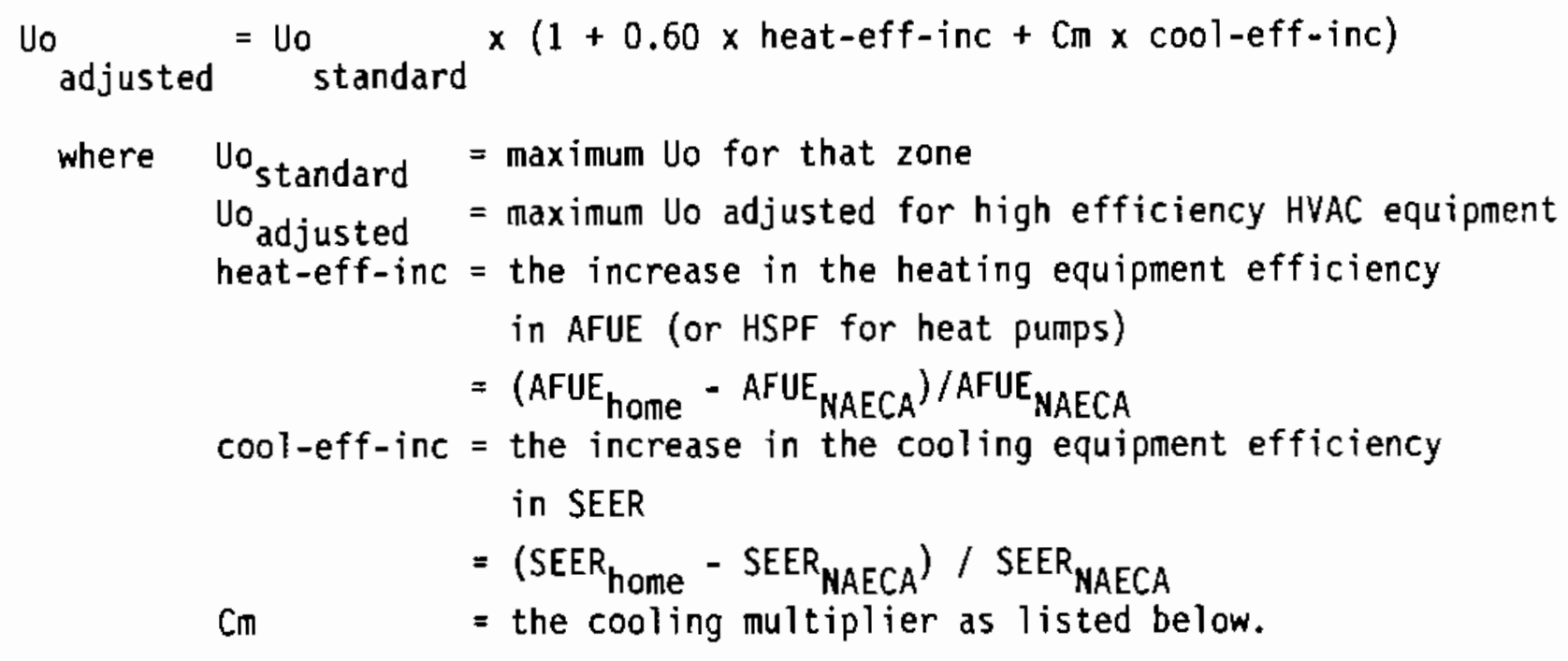

$\begin{array}{cc}\text { Zone } & \text { Cooling Multiplier }(\mathrm{Cm}) \\ 1 & 0.60 \\ 2 & 0.20 \\ 3 & 0.07 \\ 4 & 0.03\end{array}$

Homes with high efficiency heating but without cooling equipment (and viceversa) shall assume the NAECA minimums for this calculation.

(d) U-values for any glazing (windows, skylights, and the glazed portions of any door) shall be based on tests using American Architectural Manufacturers Association 1503.1-1988 (AAMA 1988). (a) In the absence of

(a) Measured data from the City of Seattle (DCLU 1988) demonstrate a considerable range of measured U-values in windows of the same general type. Therefore, the ASHRAE default values appropriate for a group of windows are probably significantly less accurate than measurement for establishing the U-value of a specific window. For that reason a measurement is specified. 
tests, the following default values must be used, with storm windows treated as an additional pane:(a)

- 1.31 for single-pane glazing

- 0.92 for double-pane glazing

- 0.79 for triple-pane glazing

- 1.23 for single-pane sliding glass doors (stider)

- 0.78 for double-pane sliding glass doors

- 0.64 for triple-pane sliding glass doors

- 0.60 for the unglazed portion of any door.

(e) Annual Energy Use Based on a Comparison. As an alternative, homes may demonstrate compliance with the annual energy use implicit in the U-value standard. The determination of annual energy use for a home must be based on generally accepted engineering practices. The general requirement is to demonstrate that the home to be approved has a projected annual energy use, including both heating and cooling, less than or equal to a similar "base case" home that meets the standard. The energy use for both homes must be calculated based on the same assumptions, including assuming the same dimensions for all boundaries between conditioned and unconditioned spaces, site characteristics, usage patterns, and climate.

(f) To moderate moisture condensation on windows and help ensure uniform temperatures in manufactured homes, homes designed for zone 4 shall be factoryequipped with storm windows or insulating glass.

(g) Supply and return ducts exposed to the outside air shall be insulated by a material having a minimum nominal thermal resistance of R-4 in zone 1 and $R-8$ in zones 2,3 , and 4 .

(a) The default window values are from the 1989 ASHRAE Fundamentals Handbook, as documented in Appendix B. These represent single-, double-, and triple-pane aluminum windows without a thermal break. Sliding glass doors default values are higher (ASHRAE 1989a, pg 27.18). The choice of default values is somewhat subjective. Measured window U-values will vary around these defaults, with most probably falling below these values (DCLU 1988). Selecting a moderately high default encourages and gives credit for low U-value windows. 


\subsection{REFERENCES}

American Architectural Manufacturers Association (AAMA). 1988. 1503.1-1988, Des Plaines, Illinois.

American Society of Heating, Refrigerating, and Air-Conditioning Engineers, Inc. (ASHRAE). 1989a. 1989 ASHRAE Handbook of Fundamentals. Atlanta, Georgia.

American Society of Heating, Refrigerating, and Air-Conditioning Engineers, Inc. (ASHRAE). 1989b. "Energy Efficient Design of New Low-Rise Residential Buildings; Public Review Draft." BSR/ASHRAE 90.2P, Atlanta, Georgia.

Backer, B. A., and J. M. Chambers. 1984. S: An Interactive Environment for Data Analysis and Graphics. Bell Telephone Laboratories, Inc., Murray Hill, New Jersey.

Boeing Aerospace Company. 1980. Variables Affecting the Economic Useful Life of Mobile Homes. PB83-185496, Seattle, Washington.

Bonneville Power Administration (BPA). 1987. "Super Good Cents Technical Specifications for Manufactured Homes." Division of Residential Programs, Portland, Oregon.

Council of American Building Officials (CAB0). 1989. Model Energy Code; 1989 Edition. Falls Church, Virginia.

Congressional Record - House (CRH), November 6, 1987, H9727.

Congressional Record - Senate (CRS), December 21, 1987, S18610.

Department of Construction and Land Use (DCLU), City of Seattle. 1988. "Glazing U-values Acceptable for Demonstrating Compliance with the 1986 Energy Code." Client Assistance Memo \#403, Seattle, Washington.

Drost, M. K. 1987. Analys is of Air-to-Air Heat Exchanger Performance Data Taken Under the Residential Standard Demonstration Program. PNL-6441, Pacific Northwest Laboratory, Richland, Washington.

Ek, C., S. A. Onisko, and G. 0. Gregg. 1988. "Air Leakage Tests of Manufactured Housing in the Northwest USA." Proceedings of the Symposium on Air Exchange Rate and Air Tightness in Bui Tdings, AtTanta, Georgia.

Electric Power Research Institute. 1982. Technical Assessment Guide. Palo Alto, California.

Electric Power Research Institute. 1988. Implicit Discount Rates in Residential Customer Choices: Volume 1: Investments in Energy Conservation Measures. EPRI EM-558̈7, Palo Alto, California. 
Energy Information Administration. 1988. State Energy Price and Expenditure Report 1986. DOE/EIA-0376(86), U.S. Department of Energy, Washington, D.C.

Energy Information Administration. 1989. Annual Energy Out look: Long-Term Projections. DOE/EIA-0383(89), U.S. Department of Energy, Washington, D.C.

Energy Security Act of 1980. Public Law 96-294.

Federal Register. 1984. Department of Housing and Urban Development - "Manufactured Home Construction and Safety Standards." Vol. 49, No. 155, pp. 31966.

Florida Manufactured Housing Industry Report. 1988. "Prime Interest Rate Increase Could Affect Manufactured Housing Sales," 1(6).

Foremost Insurance Group. 1988. Manufactured Homes: The Market Facts. Grand Rapids, Missouri.

Gates, H. 1984. Optimum Thermal Insulation for Manufactured Homes. Manufactured Housing Institute, Arlington, Virginia.

Gates, H. 1986. Occupjed Life of Mobile Homes. Manufactured Housing Institute, Arlington, Virginia.

Gates, H. 1988. Parameters Affecting the Determination of Optimum Thermal Protection Levels. Manufactured Housing Institute, Arlington, Virginia.

Harkreader, S. A., A. D. Lee, and M. P. Sherman, 1987. Current Construction Practice in Pacific Northwest Manufactured Homes and Upgrade Possibilities. D0E/BPA-846, Pacific Northwest Laboratory, Richland, Washington.

Housing and Community Development Act (HCDA) of 1987. Public Law 100-242, Section 569 .

Lee, A. D., Z. T. Taylor, G. B. Parker, G. L. Wilfert, J. W. Callaway, and S. A. Onisko. 1986. Energy and Indoor Air Quality Measurements from Five Energy Conserving Manufactured Homes. PNL-6135, Pacific Northwest Laboratory, Richland, Washington.

Lee, A. D., and C. C. Conner. 1989. Technical Support Document: Survey Data Used in Revising the Energy Conservation Requirements in the Manufactured Home Construction and Safety Standards. PNL-6842, Pacific Northwest Laboratory, Richland Washington.

Lee, T. G. 1987. "Condensation in Manufactured Housing." Alberta Municipal Affairs Housing Division, Research and Development Section. Edmonton, Alberta.

Levy, E. 1989. Development of Recommendations for Revision to the Manufactured Housing Construction and Safety Standards, Subpart $F$ - Thermal Protection. The Levy Partnership, New York, New York.

Lortz, V. B., and Z. T. Taylor. 1989. Recommendations for Energy Conservation Standards for New Residential Buildings. Volume 2: Automated 
Residential Energy Standard-User's Guide - Version 1.1. PNL-6878, Vol. 2, Pacific Northwest Laboratory, Richland, Washington.

Manufactured Housing Institute (MHI). 1984. "Comments on HUD Proposed Revisions to the Manufactured Home Construction and Safety Standards 48 Federal Regulation 37136 (1983), Appendix 5." Arlington, Virginia.

Manufactured Housing Institute. 1986. Manufactured Housing Financing 1985. Arlington, Virginia.

Meetings+PTus. 1987. 1987-88 Facts About Manufactured Home Financing and Other Industry Statistics. Palin Springs, California.

Minnesota Department of Energy and Economic Development (MDEED). 1984. Procedural Manual-Solar Energy and Energy Conservation Bank Rental Subsidy. St. Paul, Minnesota.

Mobi le/Manufactured Home Merchandiser. 1986. "1986 Mobile Manufactured Home Producers Directory." Chicago, Illinois.

National Appliance Energy Conservation Act of 1987 (NAECA), Public Law 10012. March 17, 1987.

National Institute of Standards and Technology (NIST). 1988. Energy Prices and Discount Factors for Life-Cycle Cost Analysis 1988. NISTIR 85-3273-3, Gaithersburg, Maryland.

National Research Council (NRC). 1984. "Humidity, Condensation and Ventilation in Houses." Proceedings of the Building Sciences Insight '83. Nationa] Research Council of Canada, Division of Building Research, Ottawa Canada.

Onisko, S. A. 1986. The Cost of Energy Efficiency in HUD-Code Manufactured Homes. Bonneville Power Administration, Portland, Oregon.

Riewer, S. 1988. "Demonstrating Model Conservation Standards in Manufactured Housing." Presented at the 1988 Summer Study of the American Council on an Energy Efficient Economy, Bonneville Power Administration, Portland, Oregon.

Ruegg, R. T., and S. R. Petersen. 1987. Comprehensive Guide for Least Cost Energy Decisions. NBS Special Publication 709, National Bureau of Standards, Gaithersburg, Maryland.

Steven Winter Associates. 1985. Economic Cost Benefit Analysis of Thermal Envelope Improvements for Manufactured Home Standards Revision. New York, New York.

Taylor, Z. T., et al. 1988. Impacts of Alternative Residential Energy Standards- Rural Housing Amendments Study. U.S. Department of Energy, Washington, D.C. 
U.S. Bureau of Labor Statistics (USBLS). 1988. Supplement to Producer Price Index. Government Printing office, Washington, D.C.

U.S. Department of Commerce. 1985. Annual Housing Survey: 1983, Part $F_{1}$ Energy Related Housing Characteristics. Washington, $0 . C$.

U.S. Department of Commerce. 1986. Statistical Abstract of the United States. Bureau of the Census, U.S. Government Printing Office, Washington, D.C.

U.S. Department of Commerce. 1988. Survey of Current Business. U.S. Department of Commerce, Washington, D.C.

U.S. Department of Energy (DOE). 1986. Technical Support Document in Support of Proposed Interim Energy Conservation Standards for New Federal Residential Buildings. Washington, D.C.

U.S. Federal Reserve. September 1988. Average Most Common Finance Rates (APR) on Direct Consumer Installment Loans at Reporting Commercial Banks. G.19A, supplement to Federal Reserve Statistical Release: Consumer Insta 1 lment Credit. Washington, D.C.

Zieman, M. L., and J. D. Waldman. 1984. Moisture Problems in Mobile Homes. Resources, Applications, Designs and Controls (RADCO), Inc., Gardenia, California.

24 CFR 3280. 1987. U.S. Department of Housing and Urban Development, "Manufactured Home Construction and Safety Standards." U.S. Code of Federal Regulations. 
APPENDIX A

FUEL PRICES, EQUIPMENT/FUEL TYPES, AND DEGREE DAYS BY STATE 


\section{APPENDIX A}

FUEL PRICES, EQUIPMENT/FUEL TYPES AND DEGREE DAYS BY STATE

This appendix presents information on the factors which help determine the optimum U-value for each state. These are the fuel price paid by the residence, the type of fuel chosen by the residents, and the climate.

TABLE A.1. 1988 Residential Fuel Prices by State(a)

\begin{tabular}{|c|c|c|c|c|}
\hline State & $\begin{array}{l}\text { Electricity, } \\
\text { cents/kwh }\end{array}$ & $\begin{array}{l}\text { Nat Gas, } \\
\$ / \text { therm }\end{array}$ & $\begin{array}{l}\text { LPG } \\
\text { s/gai }\end{array}$ & $\begin{array}{c}\text { Fuel } 0 i 1, \\
\text { \$/gal } \\
\end{array}$ \\
\hline Alabama & 6.4 & 0.62 & 0.70 & 0.67 \\
\hline Alaska & 9.8 & 0.32 & 1.11 & 0.95 \\
\hline Arizona & 8.6 & 0.60 & 0.87 & 0.88 \\
\hline Arkansas & 7.8 & 0.47 & 0.64 & 0.67 \\
\hline California & 7.8 & 0.49 & 0.95 & 0.77 \\
\hline Colorado & 6.9 & 0.49 & 0.59 & 0.66 \\
\hline Connecticut & 9.2 & 0.85 & 0.91 & 0.90 \\
\hline Delaware & 6.7 & 0.69 & 0.97 & 0.86 \\
\hline Washington, D.C. & 8.2 & 0.73 & 1.20 & 0.94 \\
\hline Florida & 7.9 & 0.66 & 0.90 & 0.88 \\
\hline Georgia & 6.4 & 0.64 & 0.81 & 0.84 \\
\hline Hawa i i & 9.2 & 1.47 & 1.19 & 0.77 \\
\hline Idaho & 4.5 & 0.58 & 0.84 & 0.74 \\
\hline Illinois & 9.4 & 0.49 & 0.57 & 0.73 \\
\hline Indiana & 7.2 & 0.54 & 0.66 & 0.75 \\
\hline Iowa & 7.6 & 0.50 & 0.48 & 0.73 \\
\hline Kansas & 8.1 & 0.39 & 0.47 & 0.71 \\
\hline Kentucky & 5.8 & 0.47 & 0.80 & 0.69 \\
\hline Louisiana & 7.0 & 0.55 & 0.78 & 0.66 \\
\hline
\end{tabular}

(a) The costs in Table A.1 are from the Energy Information Administration's report of 1986 prices (EIA 1988a) and inflated to 1988 prices by using the rates in Table A.2, which are taken from the January 1989 Survey of Current Business (U.S. Department of Commerce 1989, page S-6). The seasonal variation in electrical prices is shown in Table A.2. 
TABLE A.1. (contd)

Electricity, Nat Gas, LPG, Fuel 0il,

\begin{tabular}{|c|c|c|c|c|}
\hline State & cents/kwh & $\$ /$ therm & $\$$ /gal & $\$ / g a l$ \\
\hline Maine & 8.0 & 0.82 & 0.85 & 0.75 \\
\hline Maryl and & 7.2 & 0.66 & 0.98 & 0.92 \\
\hline Massachusetts & 8.2 & 0.72 & 0.78 & 0.83 \\
\hline Michigan & 7.4 & 0.55 & 0.71 & 0.82 \\
\hline Minnesota & 6.7 & 0.52 & 0.65 & 0.80 \\
\hline Mississippi & 6.6 & 0.54 & 0.75 & 0.66 \\
\hline Missouri & 7.0 & 0.49 & 0.51 & 0.71 \\
\hline Montana & 5.1 & 0.44 & 0.62 & 0.69 \\
\hline Nebraska & 5.8 & 0.46 & 0.46 & 0.71 \\
\hline Nevada & 6.5 & 0.56 & 1.02 & 0.77 \\
\hline New Hampshire & 8.4 & 0.68 & 0.88 & 0.76 \\
\hline New Jersey & 10.5 & 0.71 & 1.08 & 0.91 \\
\hline New Mexico & 8.8 & 0.52 & 0.62 & 0.71 \\
\hline New York & 10.4 & 0.72 & 0.87 & 0.92 \\
\hline North Carolina & 7.2 & 0.63 & 0.82 & 0.86 \\
\hline North Dakota & 6.0 & 0.50 & 0.53 & 0.75 \\
\hline Ohio & 7.6 & 0.55 & 0.83 & 0.78 \\
\hline Ok lahoma & 7.1 & 0.48 & 0.60 & 0.69 \\
\hline Oregon & 4.7 & 0.64 & 0.95 & 0.71 \\
\hline Pennsylvania & 8.8 & 0.61 & 0.86 & 0.82 \\
\hline Rhode Is land & 8.6 & 0.72 & 0.85 & 0.83 \\
\hline South Carolina & 7.0 & 0.63 & 0.89 & 0.87 \\
\hline South Dakota & 6.5 & 0.52 & 0.60 & 0.75 \\
\hline Tennessee & 5.1 & 0.48 & 0.78 & 0.69 \\
\hline Texas & 6.8 & 0.50 & 0.70 & 0.66 \\
\hline Utah & 7.7 & 0.48 & 0.60 & 0.71 \\
\hline Vermont & 7.8 & 0.63 & 0.87 & 0.83 \\
\hline Virginia & 6.6 & 0.62 & 0.86 & 0.87 \\
\hline Washington & 3.9 & 0.57 & 0.85 & 0.78 \\
\hline West Virginia & 6.0 & 0.58 & 0.63 & 0.75 \\
\hline Wiscons in & 6.7 & 0.61 & 0.70 & 0.76 \\
\hline Wyoming & 6.1 & 0.46 & 0.59 & 0.72 \\
\hline
\end{tabular}


The variation in fuel price by state is illustrated in Figures A.1 through A.4. The value for each state is the difference between that state's fuel price and the national average price. Figure A.5 shows the choice of fuel/equipment by region. Figures A.6 and A.7 show the variation in heating and cooling degree days across the U.S, with the value for each state being the difference between the state's heating or cooling degree days and the national average. All values in Figures A.5, A.6, and A.7 are rounded to the nearest $10 \%$. 
30

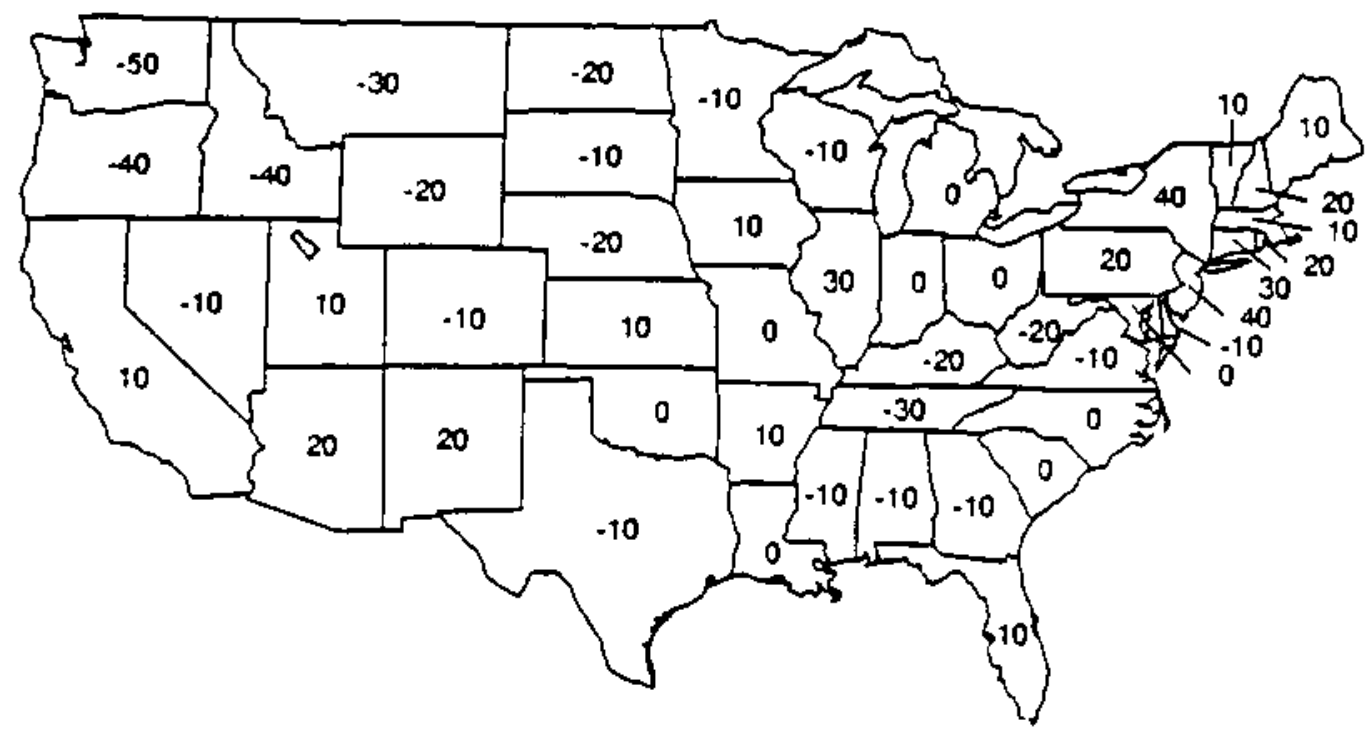

FIGURE A.1. Electricity Prices, $\%$ Difference from National Average

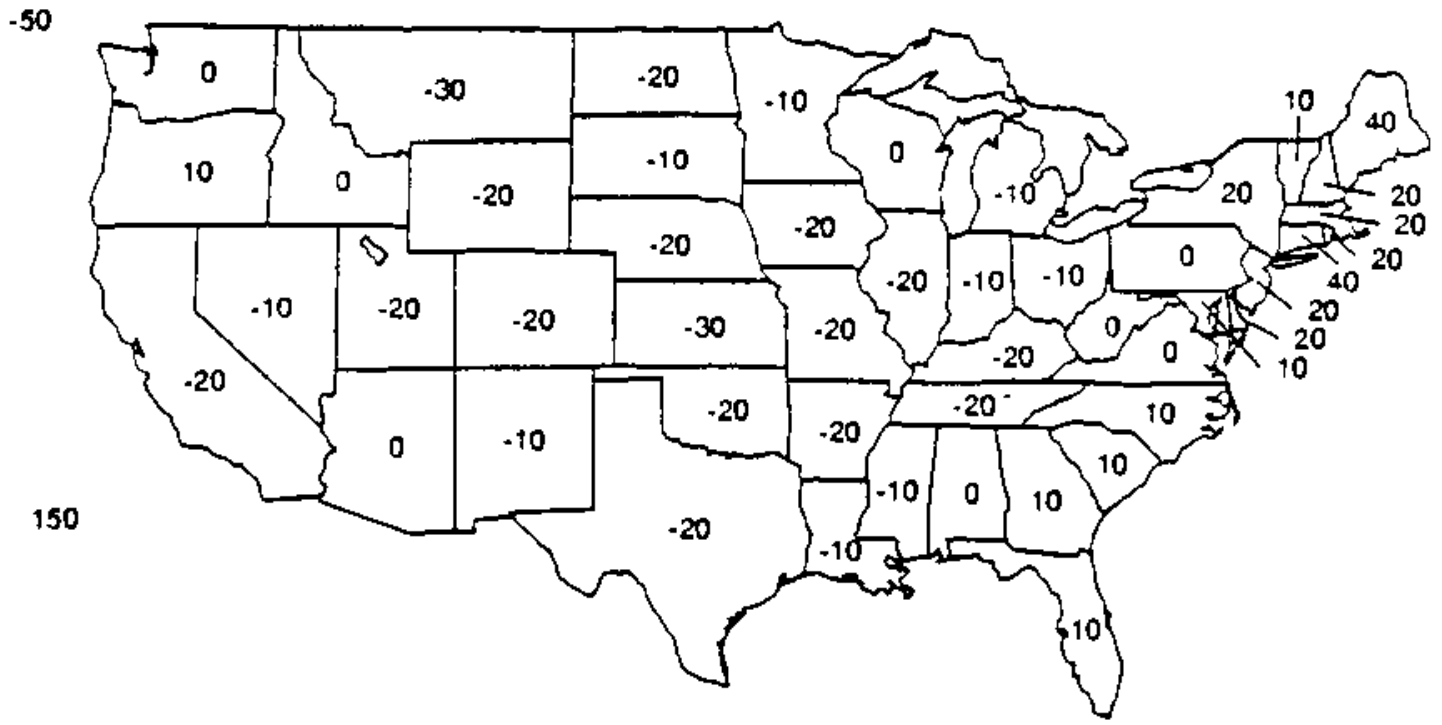

FIGURE A.2. Natural Gas Prices, \% Difference from National Average 


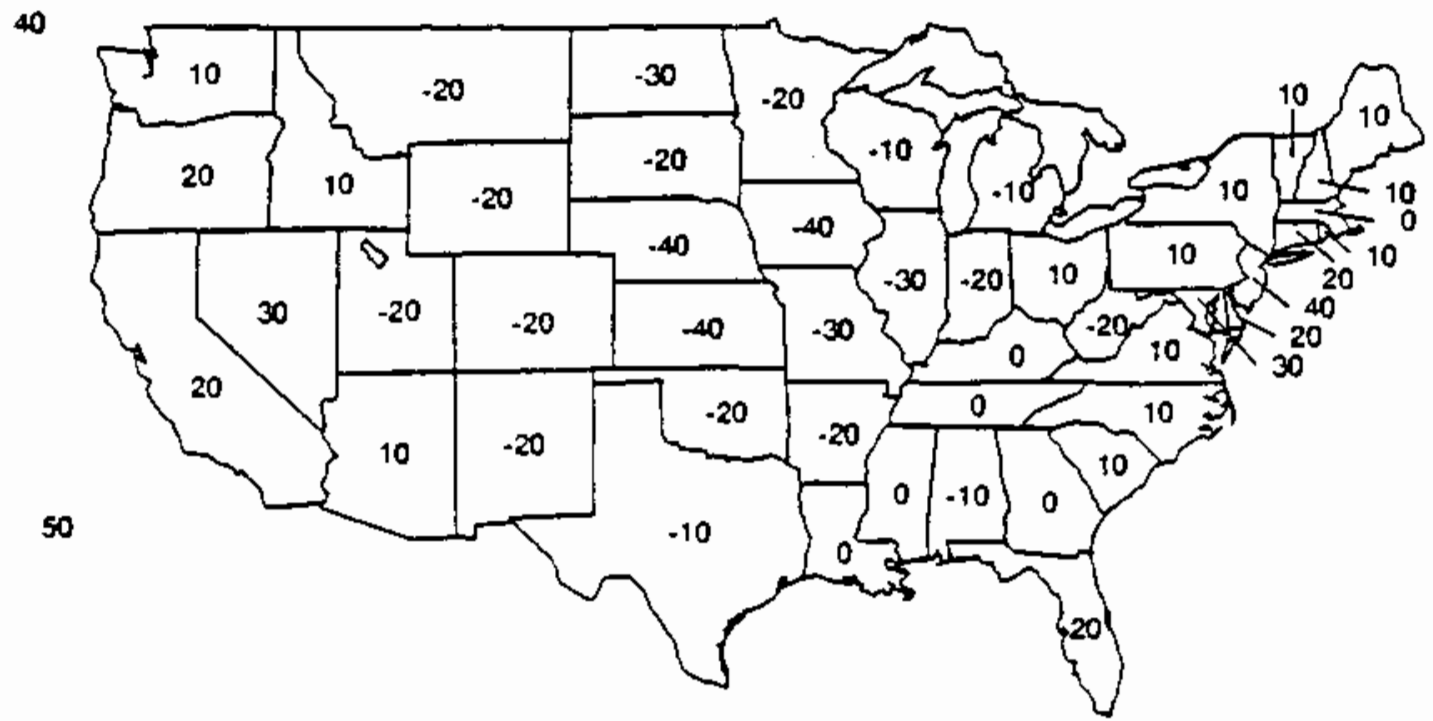

FIGURE A.3. LPG Prices, \% Difference from National Average

20

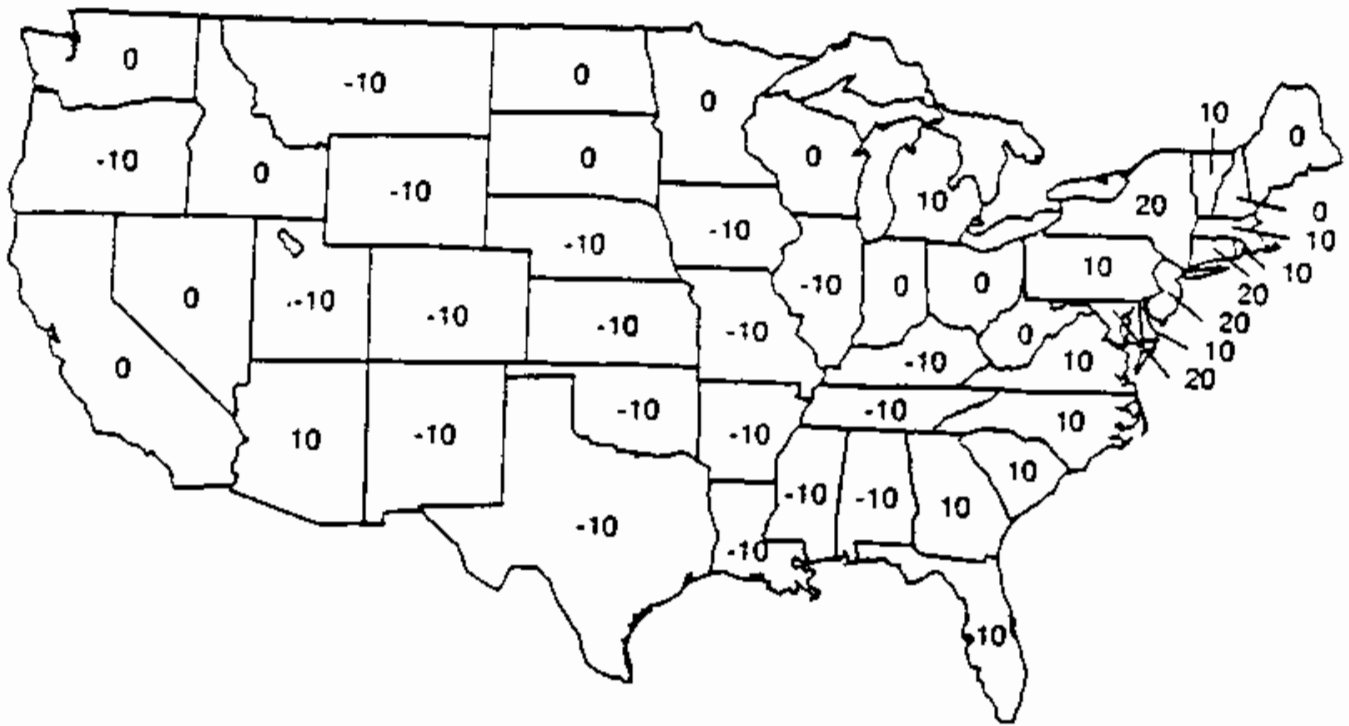

FIGURE A.4. Fuel $0 i$ ? Prices, Difference from National Average 
TABLE A.2. Nominal Fuel Escalation Rates, 1987 and 1988

$\begin{array}{lr}\frac{\text { Fue }]}{\text { Fuel oil and LPG }} & \frac{\text { Escalation Rate }(\% / 2 \text { years })}{\text { Gas and electricity }} \\ \text { G } & -1.0\end{array}$

TABLE A.3. Seasonal Electricity Price Variation(a) (b)

\begin{tabular}{|c|c|}
\hline Census Region & Winter / Summer Adjustment \\
\hline Northeast & $0.94 / 1.06$ \\
\hline North Central & $0.94 / 1.06$ \\
\hline South & $0.90 / 1.10$ \\
\hline West & $1.00 / 1.00$ (constant prices) \\
\hline
\end{tabular}

(a) The seasonality of electricity prices is clearly demonstrated by examining the variation of monthly electrical prices for the period from 1985 to 1987 using the EIA's Monthly Energy Review "Residential 01d Series" prices (EIA 1988b). During this 3-year period the annual average national electricity price fluctuated less than one-third of $1 \%$, while the monthly average price showed a clear increase every summer and decrease every winter. Nationally, the change from the average prices by month over this 3-year period was

Jan . Feb Mar Apr May June July Aug Sept Oct Nov Dec

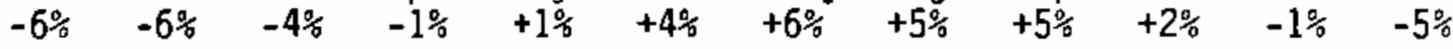

(b) The seasonal electricity variation in price was estimated from a Gas Research Institute report $(1986$, p. 11). Prices were taken from the residential, $1000 \mathrm{kwh} /$ month category. The price variations for Washington, Oregon, Idaho, and Montana were verified from rates supplied by the Northwest Public Power Association, Portland, Oregon. The estimated variation for each region was the mean of the locations reported. The ratios, used as multipliers on the annual prices, were computed as the summer or winter price divided by the sum of the summer plus winter prices. There was no seasonal adjustment for fuels other than electricity. 


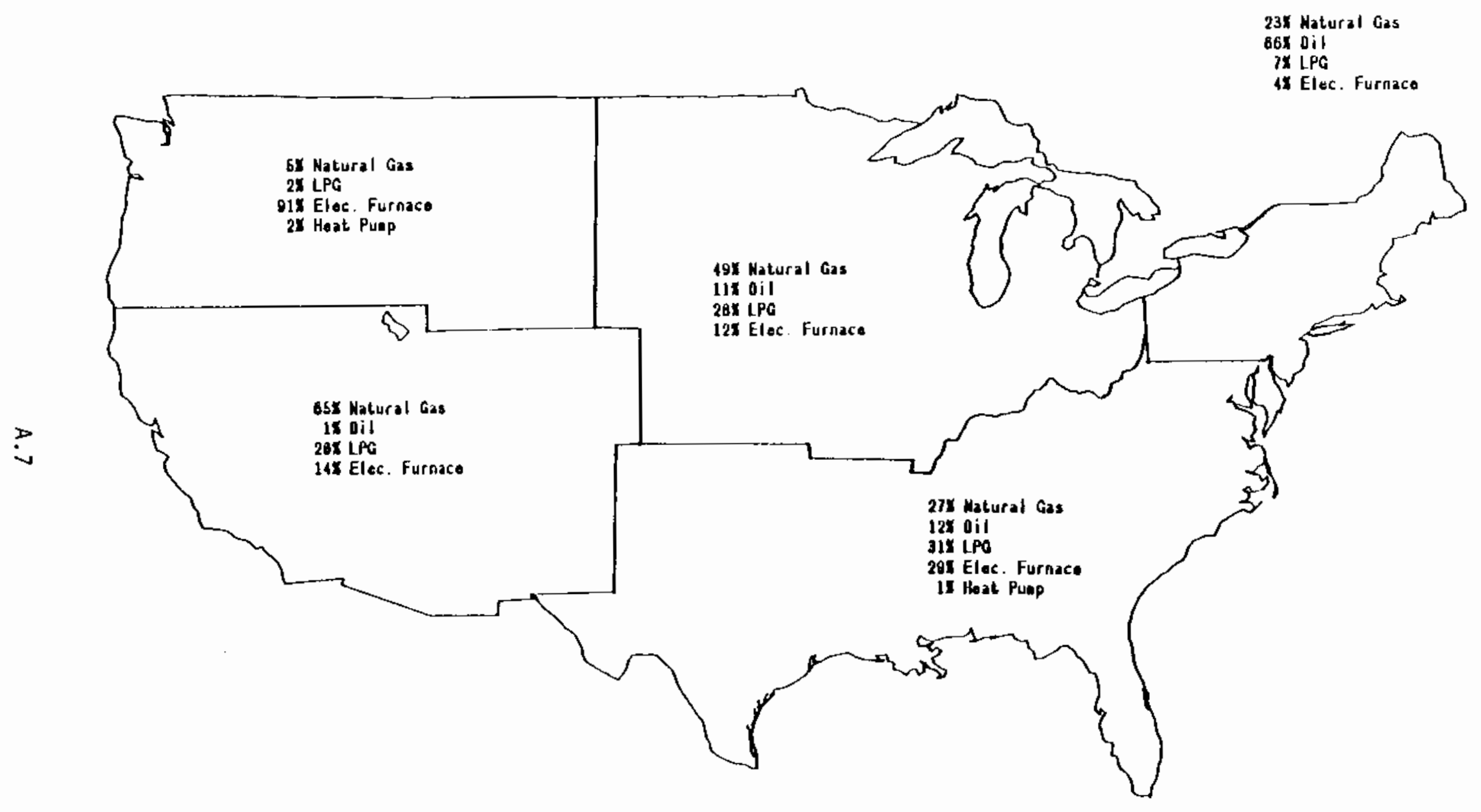

FIGURE A.5. Choice of Fuel Type by Region 


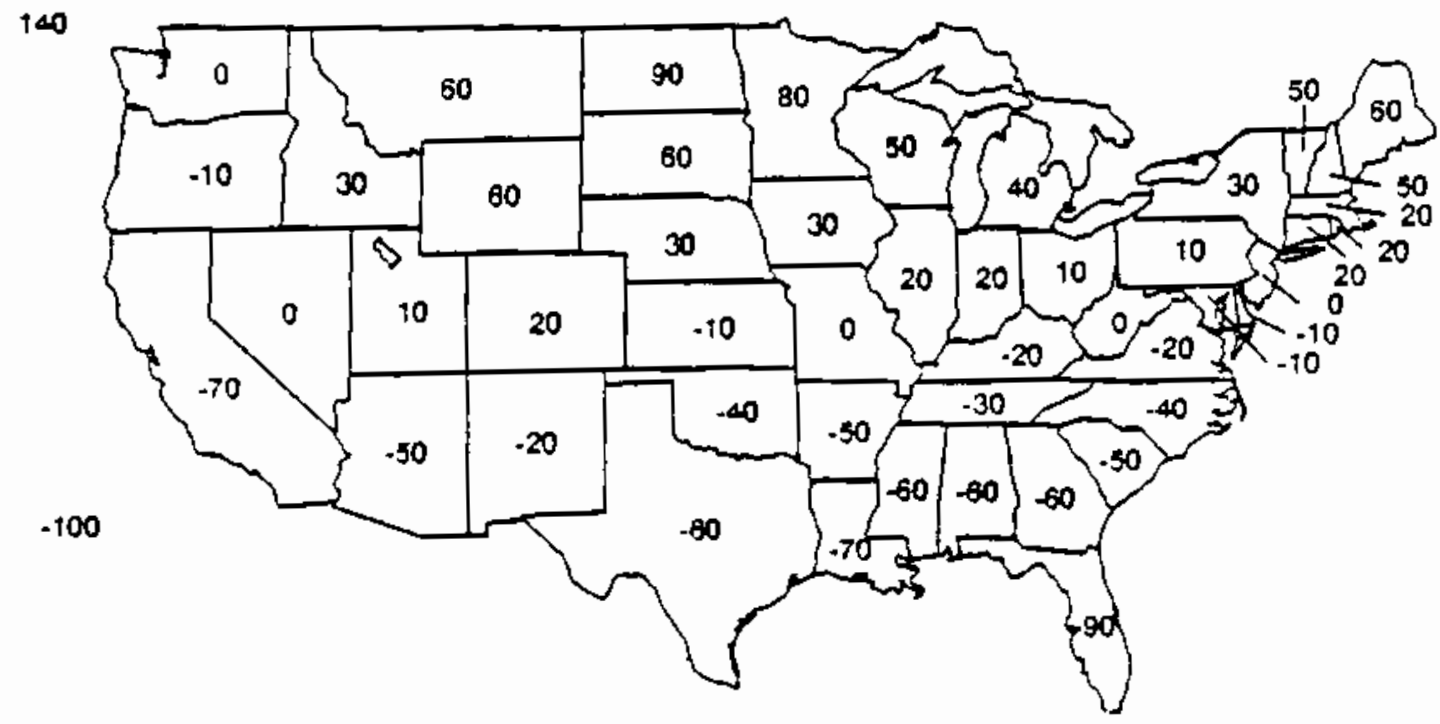

FIGURE A.6. Heating Degree Days, $\%$ Difference From National Average

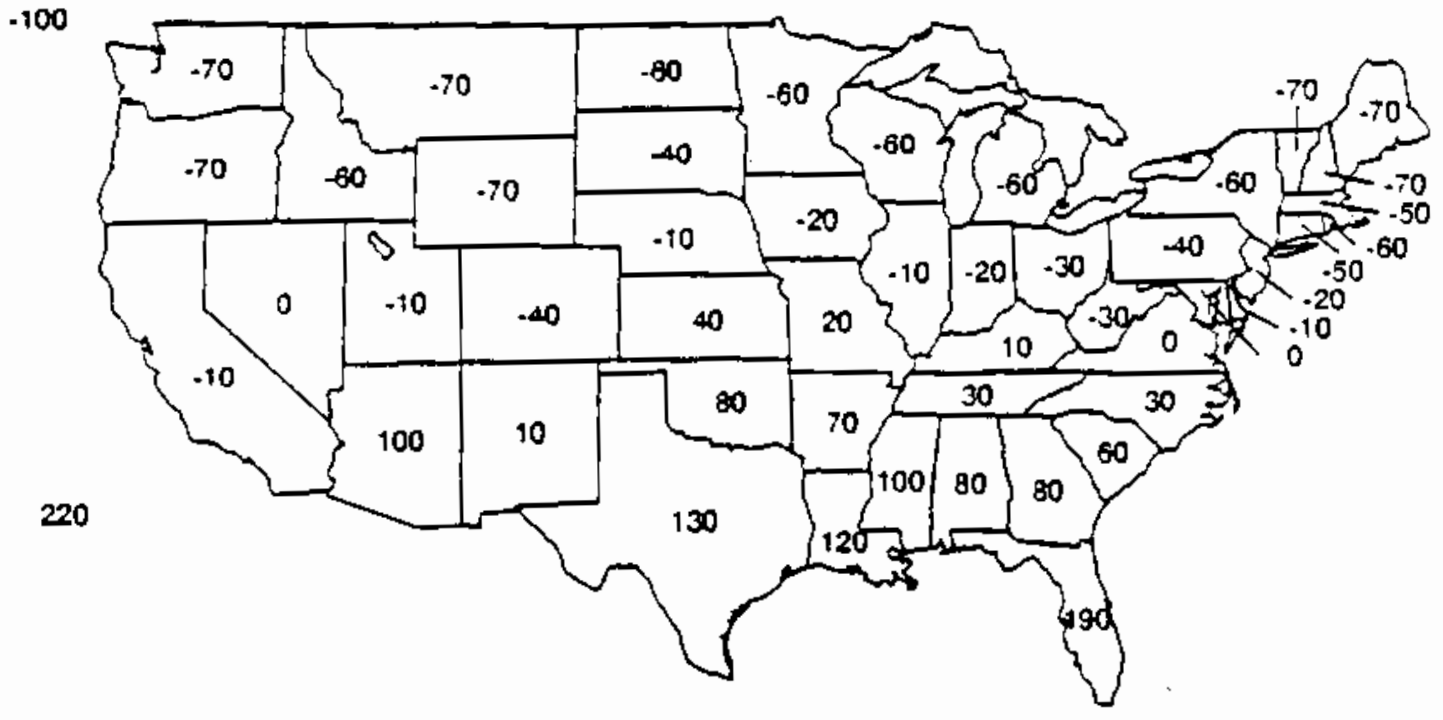

FIGURE A.7. Cooling Degree Days, \% Difference From National Average 


\section{REFERENCES}

Energy Information Administration. 1988a. State Energy Price and Expenditure Report 1986. D0E/EIA-0376(86), U.S. Department of Energy, Washington, D.C.

Energy Information Administration. 1988b. Monthly Review of Energy. DOE/EIA-0035(87/12), U.S. Department of Energy, Washington, D.C.

Gas Research Institute. 1986. Residential and Commercial Prices in Major U.S. Cities. GRI-86/0307, Chicago, Illinois.

U.S. Department of Commerce. 1989. Survey of Current Business. U.S. Department of Commerce, Washington, D.C. 
,

.

, 
APPENDIX B

COMPONENT U-VALUES 


\section{APPENDIX B}

\section{COMPONENT U-VALUES}

This appendix details the derivation of component U-values (thermal transmission coefficients) for each energy conservation measure (ECM) used in this life-cycle cost analysis. U-values were used as input to the life-cycle cost model (to determine the energy use of an option), and to establish the Uo output from the life-cycle cost model. In each case, the U-values for a building component are meant to be representative of a particular construction used in the manufactured-home industry. U-values in actual homes will vary depending on the exact details of the construction; therefore, the U-values listed here are representative of a possible home construction.

The U-values are defined for the ceilings, walls, floors, windows, and doors of a home. For the ceilings, walls, and floors, the framing and nonframing heat-flow paths are computed separately. In addition, for the ceilings and floors the heat-flow paths with and without insulation compression or reduction in thickness are computed separately. For each component the assumptions and details are given below. The basic materials and assumed Uvalues are given in Table B.1. The U-values for the windows and doors were based on average values for the types in common use, with the requirement that at least four plants report them in use on current commercial models. 
TABLE B.1. Building Materials R-values (h $\mathrm{ft}^{2}{ }^{\circ} \mathrm{F} / \mathrm{Btu}$ ) (a)

\begin{tabular}{|c|c|c|}
\hline & $\underline{\text { R-value }}$ & Material Description \\
\hline Framing members (b) & $\begin{array}{l}1.88 \\
4.38 \\
6.88\end{array}$ & $\begin{array}{l}2 \times 2 \\
2 \times 4 \\
2 \times 6\end{array}$ \\
\hline Air films $(c)(d)$ & $\begin{array}{l}0.25 \\
0.61 \\
0.92 \\
0.68\end{array}$ & $\begin{array}{l}\text { exterior air film(e) } \\
\text { horizontal air film, heat flow up } \\
\text { horizontal air film, heat flow down } \\
\text { vertical air film }\end{array}$ \\
\hline Air spaces $(f)$ & $\begin{array}{l}0.90 \\
1.02 \\
1.14 \\
1.22\end{array}$ & $\begin{array}{l}\text { horizontal heat flow, } 1.5 \text { inch space } \\
\text { downward heat flow, } 0.75 \text { inch space } \\
\text { downward heat flow, } 1.5 \text { inch space } \\
\text { downward heat flow, } 3.5 \text { inch space }\end{array}$ \\
\hline Boards & $\begin{array}{l}0.27 \\
0.82 \\
0.67 \\
0.00 \\
1.00\end{array}$ & $\begin{array}{l}\text { gypsum board, } 5 / 16 \text { inch } \\
\text { particle board, } 5 / 8 \text { inch } \\
\text { sheathing, } 7 / 16 \text { inch hardboard siding } \\
\text { bottom board (thin material holding } \\
\text { floor insulation in place) } \\
\text { interior floor covering }(g)\end{array}$ \\
\hline
\end{tabular}

(a) Except as noted, these are from the 1985 ASHRAE Fundamentals Handbook (ASHRAE 1986, page 23.6 to 23.9, TabTe 3A).

(b) Woods have a range of R-values. The commonly used R-value for wood is 1.25, which is used here. This value is also used in 1985 ASHRAE Fundamentals Handbook; example 1, page 23.10 and in Table 2, page 25.5.

(c) Interior and exterior surface air film resistance were taken from Table 1, page 23.3, 1985 ASHRAE Fundamentals Handbook. The inside surfaces resistances assume winter conditions of heat flow, with heat flow up in ceiling and down in floor. An emissivity of 0.9 was assumed.

(d) The air in ventilated spaces, such as attics and subfloors, moves slowly; therefore, the still air R-value was used instead of the $7.5 \mathrm{mph}$ or 12.5 mph air film.

(e) The exterior surface resistance is based on a $7.5 \mathrm{mph}$ wind speed, 1985 ASHRAE Fundamenta1s Handbook, page 28.5, paragraph 11.

(f) These values come from the 1985 ASHRAE Fundamentals Handbook, Table 2a, page 23.4. To use the table a mean temperature of $50^{\circ} \mathrm{F}$, a temperature difference of $30^{\circ} \mathrm{F}$, and an emissivity of 0.82 were assumed. For each air space used in the U-value calculations, the size was estimated, then the value from the table for the air space of the size nearest to the estimated size was used in the calculations. Only air spaces of a few sizes and orientations, which are listed here, were needed.

(g) ASHRAE gives the R-value of vinyl as 0.05 ; rugs as 1.23 (rug with rubber pad) and 2.08 (rug with fibrous pad). An R-value of 1 is roughly equivalent to having a home with a floor area that is four-fifths rug with rubber pad and one-fifth vinyl. 
TABLE B.1 Building Materials R-values (contd)

\begin{tabular}{|c|c|c|}
\hline \multirow{2}{*}{$\begin{array}{c}\text { Ceiling insulatior } \\
\text { (per inch) }\end{array}$} & R-value & Material Description \\
\hline & $\begin{array}{l}2.50 \\
3.23 \\
2.86\end{array}$ & $\begin{array}{l}\text { blown insulation } \\
\text { batt insulation (a) } \\
\text { average of batt and blown insulation }\end{array}$ \\
\hline $\begin{array}{l}\text { Wall and floor } \\
\text { insulation }(b)\end{array}$ & $\begin{array}{r}4.00 \\
7.00 \\
11.00 \\
13.00 \\
19.00\end{array}$ & $\begin{array}{l}\text { R-4 insulation (1.72 inch thickness) } \\
\text { R-7 insulation ( } 2.23 \text { inch thickness) } \\
\text { R-11 insulation ( } 3.50 \text { inch thickness) } \\
\text { R-13 insulation (3.50 inch thickness) } \\
\text { R-19 insulation ( } 6.00 \text { inch thickness) }\end{array}$ \\
\hline
\end{tabular}

The R-value of building materials separated from the building by a vented space is 0. (c) For example, this defines the roof in a vented attic, the exterior of the portion of a wall ventilated by weep holes, and the crawl space under the home as all having an R-value of 0 .

The effect of insulation compression on the R-value was assumed to be as illustrated in the MHCSS (24 CFR 3280, 1987, p. 229). A function describing the reduction in $R-v a l u e$ as a function of the reduction in thickness was extrapolated from the MHCSS illustration and applied to compressed batt insulation for all R-values. Blown insulation R-values were computed to vary linearly with thickness.

In "calculating U-[value]s, ideal conditions of components are assumed (i.e., insulation materials of a uniform nominal thickness and temperature, moisture effects are not involved and insulation details are in accordance with design.)"(d) Therefore, we ignore possible insulation moisture and assume the insulation void fraction is 0 . However, ASHRAE does consider areas where the insulation is missing, like over the bottom chord of the roof.(e)

(a) This is used to establish the mean value for batt and blown insulation.

(b) The insulation thickness was taken as the average of the values listed in Table 3A, page 23.6, 1985 ASHRAE Fundamentals Handbook. The thickness for R-4 and R-7 were taken as 4/11 and 7/11 of the R-11 thickness.

(c) This is the assumption made in example 3, case A, page 25.4, 1985 ASHRAE Fundamentals Handbook.

(d) 1985 ASHRAE Fundamentals Handbook. Page 23.10, first paragraph.

(e) ASHRAE does not condone improper installation of insulation, which can cause a significant increase in heat transfer. See 1985 ASHRAE Fundamentals Handbook, page 20.8 , paragraph 6 . 


\section{CEILING U-VALUES}

The following assumptions were made about ceiling construction:

- ceilings were 16 inches on center making $10 \%(a)$ of the ceiling area framing (b)

- $2 \times 2$ bottom chord

- ceiling height (attic ridge or peak height) is 30 inches for double-wide and 18 inches for single-wide

- attic cavity is ventilated with a 1 -inch vented space below roof (i.e., a 1 -inch gap is maintained between the roof sheathing and the insulation)

- the heel height is 2.5 inches up to and including R-22 insulation, and 5.5 inches above R-22 insulation

- 5/16 inch gypsum board is used on the ceiling interior.

The insulation R-values selected as options were R-11, 14, 19, 21, 22, $28,30,33$, and 38 . ( $R-38$ was used only for the double-wide.) This selection was based on industry practice, as determined by PNL surveys.

Throughout the industry, the use of insulation in ceilings is about equally split between batt and blown insulation. For a specific R-value, the batt insulation will retain a higher $R$-value in the reduced space at the roof's edge because it yields a higher R-value per inch; however, blown insulation may more easily cover a larger fraction of the bottom chord. The net result is that the ceiling U-values produced by each type of insulation are similar for a particular nominal R-value. In contrast to wall and floor insulation, in which specific increments of insulation are generally used, blown insulation can achieve any arbitrary R-value. Because the PNL survey showed a range of $R$-values, including some that are not combinations of commonly produced batt insulation, blown insulation was assumed here.

One important determinate of the ceiling U-value, especially at high Rvalues, is the fraction of the bottom chord that is covered by insulation. Opinions on what fraction of the bottom chord can be, or is, covered in manufactured homes vary widely, almost ranging from 0 to $100 \%$. For this life-

(a) From 1985 ASHRAE Fundamentals Handbook, page 23.11.

(b) From 1985 ASHRAE Fundamentals Handbook, p. 23.11 . 
cycle cost optimization, $60 \%$ of the bottom chord was assumed to be covered with insulation. (It should be noted that the alternative assumptions of an Rvalue per inch represented by the average of batt and blow insulation with a $50 \%$ chord coverage produced almost identical U-values.)

For calculation purposes, the ceilings were divided into areas as shown in Figure B.1. These areas are

- the area between the bottom chords with insulation of the full thickness in the middle portion of the roof

- the area between the bottom chords with insulation of reduced thickness in the outer portion of the roof

- the bottom chord covered by insulation up to the full height of the insulation (minus the height of the bottom chord) in the middle of the roof

- the bottom chord covered by insulation of reduced thickness on the outer portion of the roof (not shown in figure)

- the uncovered bottom chord, which is presumed to occur randomily over the length of the bottom chord.

Without Bottom Cord

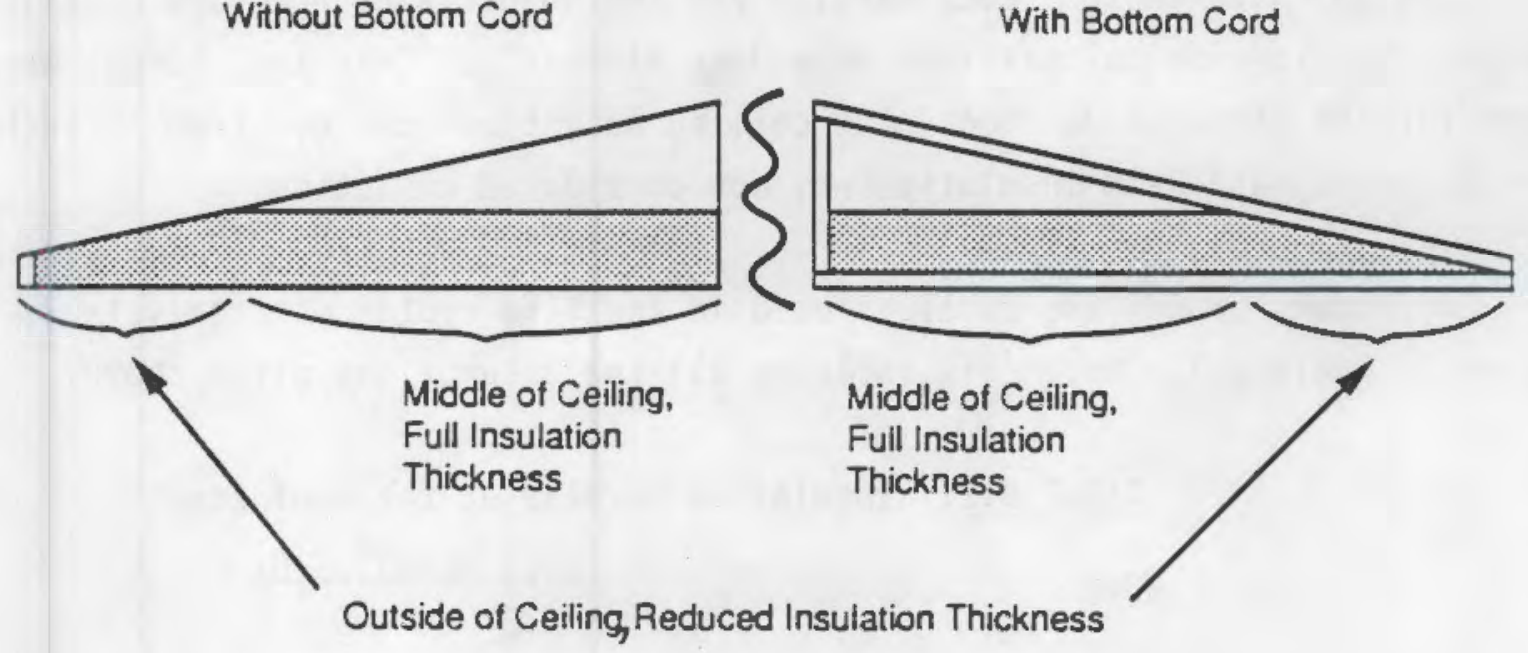

FIGURE B.1. Ceiling Insulation (not to scale)

B. 5 
The first step in calculating each ceiling R-value was to calculate the noninsulation portion of the R-value. This value does not change with insulation level. For the non-framing area between the bottom chords that R-value is

0.61 exterior air film (heat flow up)

$0.275 / 16$ inch gypsum board

0.61 interior air film (heat flow up)

$\overline{1.49}$ total noninsulation R-value for path not including bottom chord

In the area with the bottom chords and framing, the R-value of the bottom chord must be added;

0.61 exterior air film (heat flow up)

$1.882 \times 2$ bottom chord

$0.275 / 16$ inch gypsum board

0.61 interior air film (heat flow up)

3.37 total noninsulation R-value for path including bottom chord of the ceiling.

To compute the insulation R-value over the area of reduced insulation thickness, the insulation thickness at the edge of the roof must be known. This thickness varies with heel height and depends on the presence or absence of the bottom chord. (A 1 inch ventilation space has been assumed.) Recall that the insulation is R 2.5 per inch. These values are summarized in Table B.2.

The calculations for each R-value for the double-wide home are detailed below. Single-wide calculations were done similarly. Only two changes were made for the single-wide homes, the ceiling height was changed from 30 inches to 18 inches, and R-38 insulation was not considered an option.

A summary of ceiling U-values used in the life-cycle cost analysis is given in Table B.3. Note this includes all the assumptions given above.

TABLE B.2. Insulation R-value at the Roof Edge

\begin{tabular}{lrr} 
& \multicolumn{3}{l}{ Heel Height, in. } \\
\cline { 2 - 3 } & $\frac{2.5}{0.00}$ & $\frac{5.5}{7.50}$ \\
R-value on bottom chord & 0.00 & \\
R-value between bottom chords & 3.75 & 11.25
\end{tabular}


TABLE B.3. Ceiling U-values for Life-Cycle Cost Analys is

$\begin{array}{llllllllll}\text { Prototype } & \frac{R-11}{\text { double }} & \frac{R-14}{0.094} & \frac{R-19}{0.080} & \frac{R-068}{0.064} & \frac{R-21}{0.063} & \frac{R-28}{0.049} & \frac{R-30}{0.047} & \frac{R-33}{0.045} & \frac{R-38}{0.043} \\ \text { single } & 0.097 & 0.085 & 0.074 & 0.071 & 0.070 & 0.052 & 0.051 & 0.050 & \text { NA }\end{array}$

The detailed calculations for double-wide homes are shown below.

Insulation R-value $=11$

Insulation thickness $=4.4$ inches

Fraction of ceiling with reduced insulation thickness $=10 \%(a)$

\begin{tabular}{|c|c|c|c|c|c|}
\hline \multirow{7}{*}{$\begin{array}{l}\text { Fraction of ceiling } \\
\text { Constant R-value } \\
\text { Insulation R-value } \\
\text { Total path R-value } \\
\text { Path U-value }\end{array}$} & \multicolumn{3}{|c|}{$\begin{array}{l}\text { Framing (Bottom Chord) } \\
\text { Insulation }\end{array}$} & \multicolumn{2}{|c|}{$\begin{array}{l}\text { Non-Framing } \\
\text { Insulation }\end{array}$} \\
\hline & None(b) & FuT1 & Partial & Full & Partial \\
\hline & $\overline{4.0}$ & $5.4 \%$ & 0.6 & $80.8 \%$ & $9.2 \%$ \\
\hline & 3.3 & 3.37 & 3. & 1.49 & 1.49 \\
\hline & 0.00 & 7.25 & variab & 11.00 & variable \\
\hline & 3.37 & 10.62 & 6.32 & 12.49 & 8.35 \\
\hline & 0.297 & & 0.158 (c) & 0.080 & \\
\hline
\end{tabular}

Insulation R-value $=14$

Insulation thickness $=5.6$ inches

Fraction of ceiling with reduced insulation thickness $=14 \%$

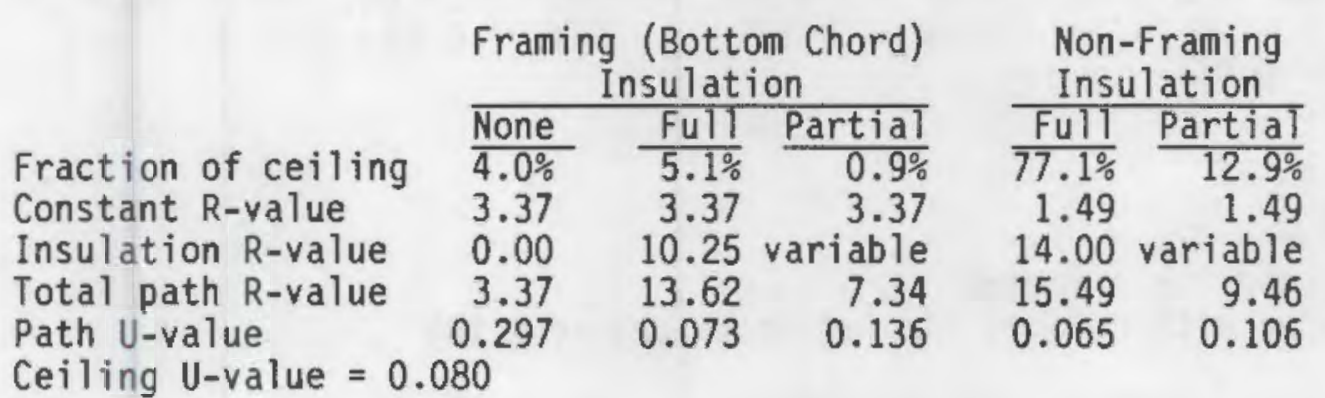

(a) For both the framing and non-framing areas, the fraction with insulation of reduced thickness was calculated as the ratio of the rise of the insulation height over its run, to the rise of the roof height over its run. Note that the insulation height at the roof edge varies with heel height and presence or absence of the bottom cord.

(b) For purposes of calculation, the uncovered area of the bottom cord was assumed to be distributed equally along the length of the bottom cord.

(c) The effective U-value of all areas where the blown insulation thickness was constrained by the slope of the roof was computed as the integral of the U-value over the range from the roof edge to the place where the insulation thickness was not reduced. The formula was

Path $\mathrm{U}$-value $=(\ln$ (path R-value at full insulation thickness) In (path R-value at roof edge)) / change in R-value 
Insulation $R$-value $=19$

Insulation thickness $=7.6$ inches

Fraction of ceiling with reduced insulation thickness $=21 \%$

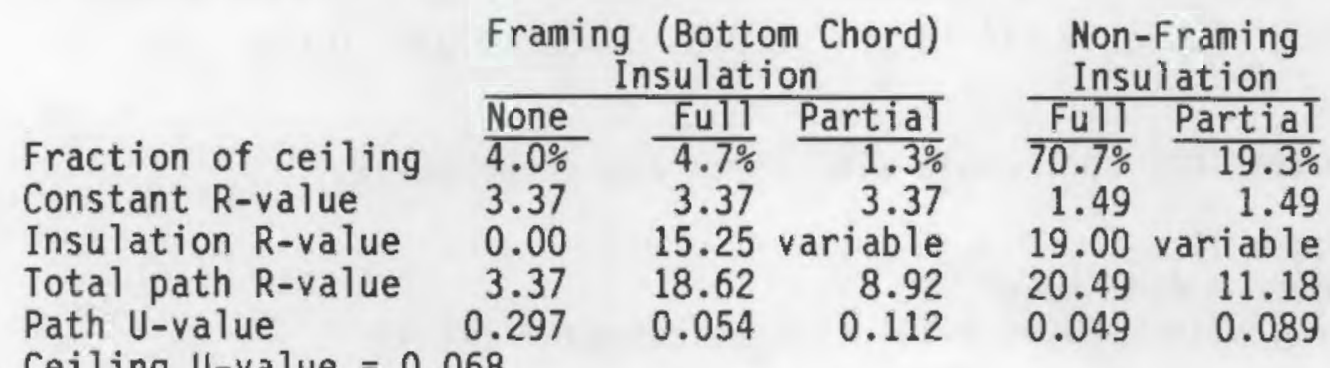

Ceiling $U$-value $=0.068$

Insulation R-value $=21$

Insulation thickness $=8.4$ inches

Fraction of ceiling with reduced insulation thickness

\begin{tabular}{|c|c|c|c|c|c|}
\hline \multirow{7}{*}{$\begin{array}{l}\text { Fraction of ceiling } \\
\text { Constant R-value } \\
\text { Insulation R-value } \\
\text { Total path R-value } \\
\text { Path U-value }\end{array}$} & \multicolumn{3}{|c|}{$\begin{array}{l}\text { Framing (Bottom Chord) } \\
\text { Insulation }\end{array}$} & \multicolumn{2}{|c|}{$\begin{array}{l}\text { Non-Framing } \\
\text { Insulation }\end{array}$} \\
\hline & None & $\frac{\text { FuT }}{\Delta 5 \%}$ & Partial & $\frac{\mathrm{FulT}}{682 \%}$ & Partial \\
\hline & 4.0 & $4.5 \%$ & $1.5 \%$ & $68.2 \%$ & $21.8 \%$ \\
\hline & 3.37 & 3.37 & 3.3 & 1.49 & 1.49 \\
\hline & 0.00 & 17.25 & variable & 21.00 & variable \\
\hline & & 20.62 & 9.5 & 22.49 & 11.84 \\
\hline & 0.297 & 0.048 & 0.105 & 0.044 & 0.084 \\
\hline
\end{tabular}

Ceiling U-value $=0.064$

Insulation R-value $=22$

Insulation thickness $=8.8$ inches

Fraction of ceiling with reduced insulation thickness $=26 \%$

\begin{tabular}{|c|c|c|c|c|c|}
\hline \multirow{6}{*}{$\begin{array}{l}\text { Fraction of ceiling } \\
\text { Constant R-value } \\
\text { Insulation R-value } \\
\text { Total path R-value } \\
\text { Path U-value }\end{array}$} & \multicolumn{3}{|c|}{$\begin{array}{l}\text { Framing (Bottom Chord) } \\
\text { Insulation }\end{array}$} & \multicolumn{2}{|c|}{$\begin{array}{l}\text { Non-Framing } \\
\text { Insulation }\end{array}$} \\
\hline & $\frac{\overline{\text { None }}}{4.0 \%}$ & $\frac{\text { Ful1 }}{4.5 \%}$ & $\frac{\text { Partial }}{1.5 \%}$ & $\frac{\text { FulT }}{66.9 \%}$ & $\frac{\text { Partial }}{23.1 \%}$ \\
\hline & $\begin{array}{l}4.0 \% \\
3.37\end{array}$ & $\begin{array}{l}4.5 \% \\
3.37\end{array}$ & & $66.9 \%$ & $\begin{array}{r}23.1 \% \\
1.49\end{array}$ \\
\hline & & 18.25 & variable & 22.00 & variable \\
\hline & 3. & 21.62 & 9.82 & 23.49 & 12.16 \\
\hline & & 0.046 & 0.102 & 0.043 & 0.082 \\
\hline
\end{tabular}


The heel height is 5.5 inches for the insulation levels of R-28 and above.

Insulation $R$-value $=28$

Insulation thickness $=11.2$ inches

Fraction of ceiling with reduced insulation thickness $=26 \%$

\begin{tabular}{|c|c|c|c|c|c|}
\hline \multirow{8}{*}{$\begin{array}{l}\text { Fraction of ceiling } \\
\text { Constant R-value } \\
\text { Insulation R-value } \\
\text { Total path R-value } \\
\text { Path U-value } \\
\text { Ceiling U-value = }\end{array}$} & \multicolumn{3}{|c|}{$\begin{array}{l}\text { Framing (Bottom Chord) } \\
\text { Insulation }\end{array}$} & \multicolumn{2}{|c|}{$\begin{array}{l}\text { Non-Framing } \\
\text { Insulation }\end{array}$} \\
\hline & None & FuTl & Partial & FuTा & Partial \\
\hline & $4.0 \%$ & $4.4 \%$ & $1.6 \%$ & $66.4 \%$ & $23.6 \%$ \\
\hline & 3.37 & 3.37 & 3.37 & 1.49 & 1.49 \\
\hline & 0.00 & 24.25 & variable & 28.00 & variable \\
\hline & 3.37 & 27.62 & 17.96 & 29.49 & 19.96 \\
\hline & 0.297 & 0.036 & 0.056 & 0.034 & 0.050 \\
\hline & & & & & \\
\hline
\end{tabular}

Insulation R-value $=30$

Insulation thickness $=12.0$ inches

Fraction of ceiling with reduced insulation thickness $=29 \%$

\begin{tabular}{|c|c|c|c|c|c|}
\hline \multirow[b]{3}{*}{ Fraction of ceiling } & \multicolumn{3}{|c|}{$\begin{array}{l}\text { Framing (Bottom Chord) } \\
\text { Insulation }\end{array}$} & \multicolumn{2}{|c|}{$\begin{array}{l}\text { Non-Framing } \\
\text { Insulation }\end{array}$} \\
\hline & None & FuT1 & Partial & FuTl & Partial \\
\hline & $4.0 \%$ & $4.2 \%$ & $1.8 \%$ & $6 \overline{3,5 \%}$ & $26.5 \%$ \\
\hline Constant R-value & 3.37 & 3.37 & 3.37 & 1.49 & 1.49 \\
\hline Insulation R-value & 0.00 & 26.25 & variable & 30.00 & variable \\
\hline 1) path R-value & 3. & 29.62 & 18.70 & 31.49 & 20.72 \\
\hline U-value & 0.297 & 0.034 & 0.053 & 0.032 & 0.048 \\
\hline
\end{tabular}

Ceiling $\mathrm{U}$-value $=0.047$

Insulation R-value $=33$

Insulation thickness $=13.2$ inches

Fraction of ceiling with reduced insulation thickness $=34 \%$

\begin{tabular}{|c|c|c|c|c|c|}
\hline \multirow{8}{*}{$\begin{array}{l}\text { Fraction of ceiling } \\
\text { Constant R-value } \\
\text { Insulation R-value } \\
\text { Total path R-value } \\
\text { Path U-value } \\
\text { Ceiling U-value = }\end{array}$} & \multicolumn{3}{|c|}{$\begin{array}{l}\text { Framing (Bottom Chord) } \\
\text { Insulation }\end{array}$} & \multicolumn{2}{|c|}{$\begin{array}{l}\text { Non-Framing } \\
\text { Insulation }\end{array}$} \\
\hline & $\frac{\text { None }}{40 \%}$ & $\frac{\mathrm{FulT}}{40 \%}$ & $\frac{\text { Partial }}{20^{\circ}}$ & $\frac{\text { FuTा }}{503 \%}$ & $\frac{\text { Partial }}{3070}$ \\
\hline & $4.0 \%$ & $4.0 \%$ & $2.0 \%$ & $59.3 \%$ & $30.7 \%$ \\
\hline & 3.37 & 3.37 & 3.37 & 1.49 & 1.49 \\
\hline & 0.00 & 29.25 & variable & 33.00 & variable \\
\hline & 3.37 & 32.62 & 19.79 & 34.49 & 21.84 \\
\hline & & 0.031 & 0.051 & 0.029 & 0.046 \\
\hline & & & & & \\
\hline
\end{tabular}


Insulation R-value $=38$

Insulation thickness $=15.2$ inches

Fraction of ceiling with reduced insulation thickness $=42 \%$

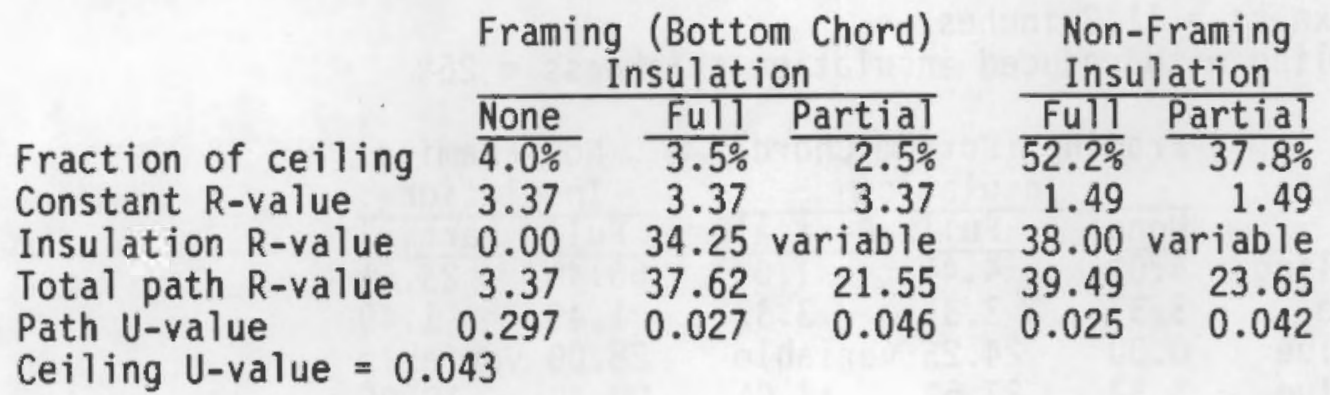




\section{WALL U-VALUES}

The following assumptions were made about wall construction.

- All walls are 16 inches on center; therefore, $15 \%(a)$ of the wall area is made up of the heat-flow path including the joist.

- Studs are $2 \times 4$, except at R-19 where $2 \times 6$ studs are assumed.

- Sheathing is $7 / 16$ inch hardboard sheathing.

- Interior is 5/16 inch gypsum board.

- Walls are vented to the exterior air.

The insulation R-values selected as options were $R-7,11,13,14$, and 19. This selection was based on industry practice as reported in PNL's industry surveys.

For calculation purposes, the walls were divided into two areas:

- the area including the stud

- the area including the insulation but without the stud.

The first step in calculating each wall U-value was to determine the constant noninsulation portion. This value does not change with the addition of insulation. For the non-stud heat-flow path this R-value is:

0.00 exterior air film and exterior materials

0.68 air film

0.27 gypsum board, $5 / 16$ inch

0.68 interior air film (horizontal heat flow)

$\overline{1.63}$ total constant $R$-value of non-stud path

In the area with the stud, the R-value of the stud must be added

1.63 non-stud constant R-value

$4.382 \times 4$ stud

$\overline{6.01}$ total constant R-value for framing path

(a) From 1985 ASHRAE Fundamentals Handbook, page 23.10. The reference states that this includes an allowance for multiple studs, plates, sills, and extra framing around windows and doors. 
or with the $2 \times 6$ stud at R-19

1.63 non-stud constant R-value

$6.882 \times 6$ stud

8.51 total of constant R-value for framing path

TABLE B.4. Wall U-values for Life-cycle Cost Analysis

U-value $\quad \frac{\mathrm{R}-7}{0.114} \quad \frac{\mathrm{R}-11}{0.093} \quad \frac{\mathrm{R}-13}{0.083} \quad \frac{\mathrm{R}-14}{0.086} \quad \frac{\mathrm{R}-19}{0.061}$

The wall U-values are summarized in Table B.4. The detailed calculations for these walls are shown below.

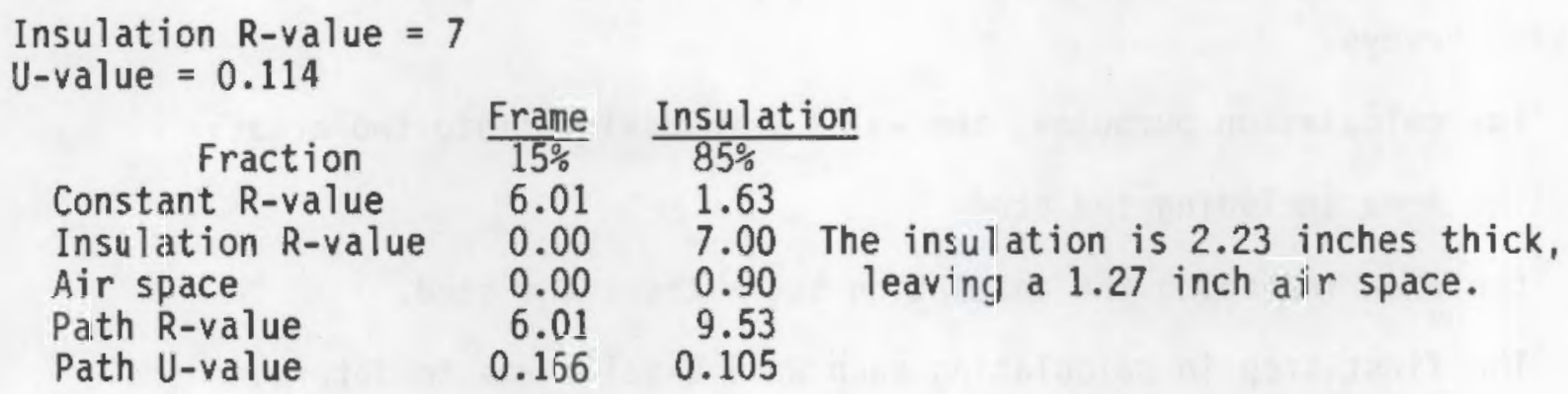

Insulation $\mathrm{R}$-value $=11$

U-value $=0.093$

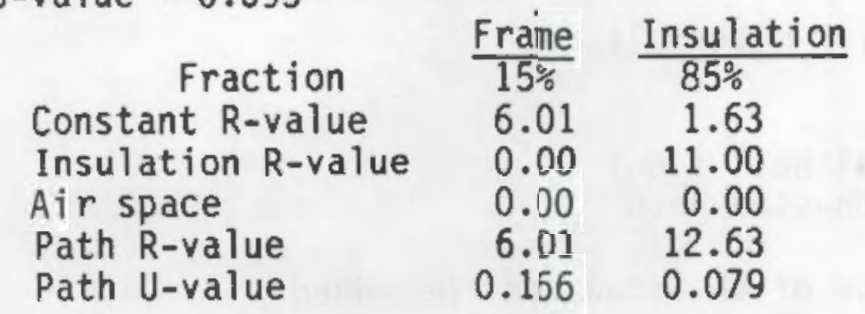

Insulation R-value $=13$

U-value $=0.083$

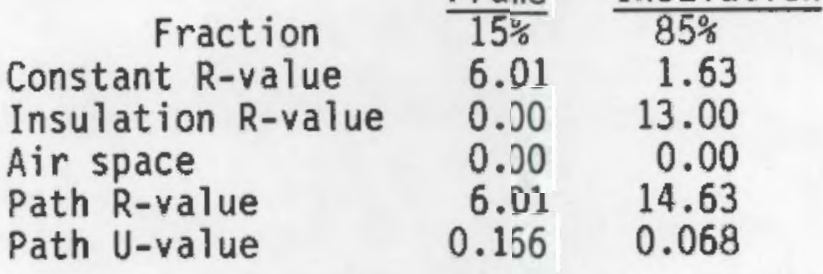


Insulation $\mathrm{R}$-value $=14$

$U$-value $=0.086$

\begin{tabular}{|c|c|c|c|}
\hline $\begin{array}{l}\quad \text { Fraction } \\
\text { Constant R-value } \\
\text { Insulation R-value } \\
\text { Air space } \\
\text { Path R-value } \\
\text { Path U-value }\end{array}$ & $\begin{array}{l}\frac{\text { Frame }}{15 \%} \\
6.01 \\
0.00 \\
0.00 \\
6.01 \\
0.166\end{array}$ & $\begin{array}{l}\frac{\text { Insulation }}{85 \%} \\
1.63 \\
12.32 \\
0.00 \\
13.95 \\
0.072\end{array}$ & $\begin{array}{l}\text { The R-14 insulation is made up of } 2 \\
\text { R-7 batts that total } 4.4 \text { inches in } \\
\text { thickness in a } 3.5 \text { inch space. This } \\
20 \% \text { compression results in a } 12 \% \\
\text { reduction in the R-value. }\end{array}$ \\
\hline \multicolumn{4}{|c|}{$\begin{array}{l}\text { Insulation R-value }=19 \\
\text { U-value }=0.061\end{array}$} \\
\hline $\begin{array}{l}\quad \text { Fraction } \\
\text { Constant R-value } \\
\text { Insulation R-value } \\
\text { Air space } \\
\text { Path R-value } \\
\text { Path U-value }\end{array}$ & $\begin{array}{l}\frac{\text { Frame }}{15 \%} \\
8.75 \\
0.00 \\
0.00 \\
8.75 \\
0.114\end{array}$ & $\begin{array}{l}\text { Insulation } \\
85 \% \\
1.63 \\
18.05 \\
0.00 \\
19.68 \\
0.051\end{array}$ & $2 \times 6$ studs \\
\hline
\end{tabular}




\section{FLOOR U-VALUES}

The following assumptions were made about floor construction.

- Al1 floor joists are $2 \times 6$ s spaced 16 inches on center; therefore, $10 \%$ of the floor area is made up of the heat-flow path including the stud.

- Roll insulation is used from R-7 to R-14; at R-18 and above, a combination of roll and joist insulation is used.

- The subfloor is "heated" from R-7 to R-14; at R-18 and above, the ducts are insulated and the subfloor is "unheated".

- The floor area is divided equally between the outer area, where the roll insulation is held against the joists, and the middle area, where the roll insulation does not touch the joists.

- Joist insulation is held between the joists such that the bottom of the batt aligns with the bottom of the joists.

- The subfloor is $5 / 8$ inch particle board.

- The interior floor covering has an R-value of 1, which corresponds to a home that is largely covered with carpet but has areas of vinyl.

Generally in constructing an insulated floor, rolled insulation is placed under the floor and pressed up against the framing. The extent of the compression of the insulation against the framing varies with the home. For this calculation the insulation was assumed to lose $12.5 \%$ of its R-value between the floor joists (MHCSS, page 229) and 75\% of its R-value where it touches the floor joists. The "bottom board" in the middle portion of the subfloor containing the duct was assumed to extend below the rest of the roll insulation such that it would accommodate the duct without significant insulation compression.

The insulation R-values selected as options were R-7, 11, 14, 18, and 22. This selection was based on industry practice as reported in PNL's industry surveys. 
For calculation purposes, the floors were divided into the four areas, as shown in Figure B.2. These areas were

- the framing area in the center of the home where the roll insulation does not get compressed by the frame (note that, for "heated" floors, the floor joists have no insulating value and this area is treated as an extension of the nonframing area in the center of the home)

- the framing area on the outside portions of the home where the rolled insulation is pressed against the frame

- the non-framing area in the center of the home where the insulation is not compressed

- the non-framing area on the outer portions of the home where the rolled insulation is slightly compressed by the adjacent framing members.

Without Framing

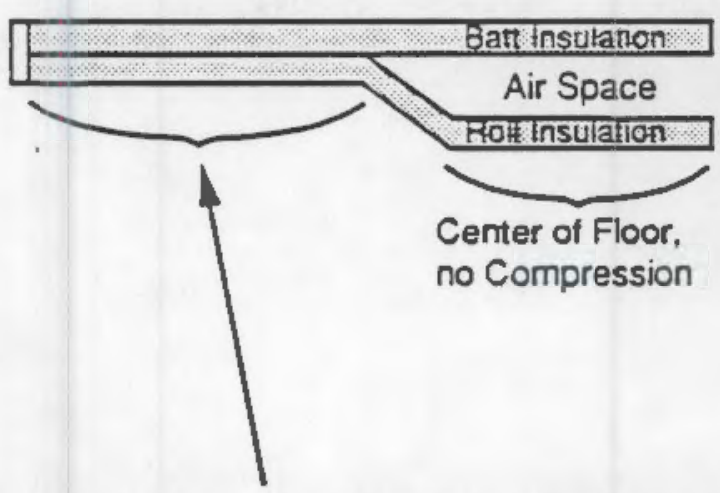

With Framing

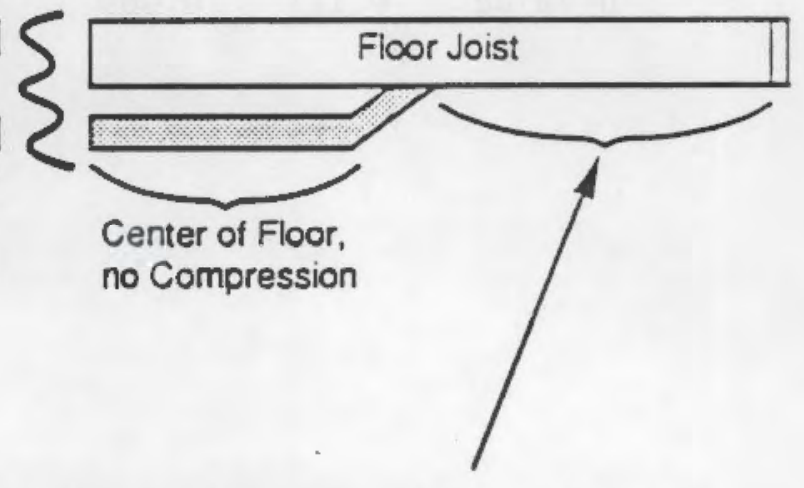

Outer Portion of Floor, Rolled insulation Compressed against Frame, Rolled Insulation may also be Compressed against Batt Insulation

FIGURE B.2. Floor Insulation (not to scale) 
The first step in calculating each floor U-value was to calculate the noninsulation, non-joist portion of the $R$-value. This value does not change with the addition of insulation or at the framing members. This was calculated separately for the "heated" and "unheated" subfloors.

Constant R-value portion of all heat-flow paths for the heated subfloor

0.00 crawl space

0.92 exterior air film(a)

0.00 bottom board (vinyl or kraft)

$0.005 / 8$ inch particle board

0.00 floor covering (mostly rug, some vinyl)

0.92 interior air film

$\overline{1.84}$ total constant R-value

Constant R-value portion of all heat-flow paths for the unheated subfloor

0.00 crawl space

0.92 exterior air film

0.00 bottom board (vinyl or kraft)

$0.825 / 8$ inch particle board

1.00 floor covering (mostly rug, some vinyl)

0.92 interior air film

$\overline{3.66}$ total constant $R$-value

The floor U-values are summarized in Table B.5.

TABLE B.5. Floor U-values Used for the Life-Cycle Cost Analysis

U-value $\quad \frac{\mathrm{R}-7}{0.127} \quad \frac{\mathrm{R}-11}{0.089} \quad \frac{\mathrm{R}-14}{0.073} \quad \frac{\mathrm{R}-18}{0.046} \quad \frac{\mathrm{R}-22}{0.041}$

(a) If the home includes skirting, the air speed under the home will be very slow. Even homes without skirting are almost always surrounded by other homes, trees, or other obstructions to the wind. The ground, the obstructions to the wind, and the restricted space under the home would greatly slow wind speeds under the home. Therefore, the exterior air film is probably best approximated by the air film for still air. 
The detailed calculations for the floor U-values are given below. Note that from R-7 to R-14 the subfloor is considered heated. At R-18 and above, the assumption is made that the ducts are insulated and the subfloor is considered unheated.

\begin{tabular}{|c|c|c|c|c|}
\hline & $\frac{F r a}{\text { Insul }}$ & $\frac{m e}{\text { ation }}$ & $\frac{\text { Non-F }}{\text { Insul }}$ & ame \\
\hline $\begin{array}{l}\text { Fraction of floor area } \\
\text { Constant R-value } \\
\text { Roll insulation } \\
\text { Floor joists }(2 \times 6) \\
\text { Air space above roll } \\
\text { Total path R-value } \\
\text { Path U-value }\end{array}$ & $\frac{\mathrm{Fu} 11}{0.0 \%}$ & $\begin{array}{c}\text { Partial } \\
5.0 \% \\
1.84 \\
1.75 \\
0.00 \\
0.00 \\
3.59 \\
0.279\end{array}$ & $\begin{array}{l}\text { Fu11 } \\
50.0 \% \\
1.84 \\
7.00 \\
0.00 \\
0.00 \\
8.84 \\
0.113\end{array}$ & $\begin{array}{l}\text { Partial } \\
45.0 \% \\
1.84 \\
6.13 \\
0.00 \\
0.00 \\
7.97 \\
0.126\end{array}$ \\
\hline
\end{tabular}

Insulation R-value $=11$

Roll insulation $=11$

Batt insulation $=0$

Fraction of floor area

Constant R-value

Roll insulation

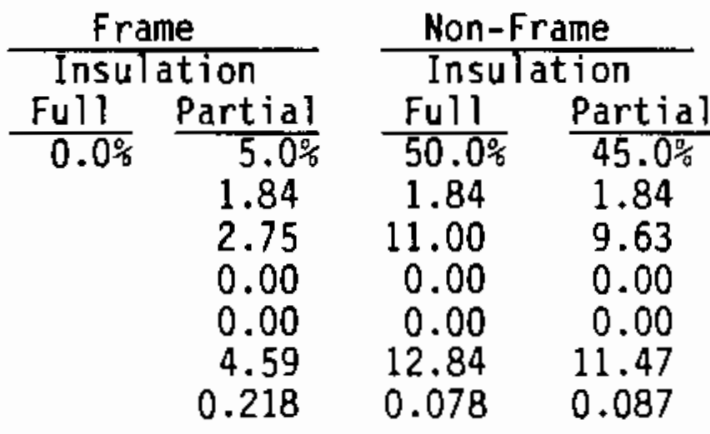

Path U-value

Floor U-value $=0.089$ 


\begin{tabular}{|c|c|c|c|c|}
\hline \multirow[b]{2}{*}{$\begin{array}{l}\text { Fraction of floor area } \\
\text { Constant R-value } \\
\text { Roll insulation } \\
\text { Floor joists }(2 \times 6) \\
\text { Air space above roll } \\
\text { Total path R-value } \\
\text { Path U-value }\end{array}$} & \multicolumn{2}{|c|}{ Frame } & \multicolumn{2}{|c|}{ Non-Frame } \\
\hline & $\frac{\mathrm{Full}}{0.0 \%}$ & $\begin{array}{c}\text { Partial } \\
5.0 \% \\
1.84 \\
3.50 \\
0.00 \\
0.00 \\
5.34 \\
0.187\end{array}$ & $\begin{array}{c}\text { Full } \\
50.0 \% \\
1.84 \\
14.00 \\
0.00 \\
0.00 \\
15.84 \\
0.063\end{array}$ & $\begin{array}{c}\text { Partia T } \\
45.0 \% \\
1.84 \\
12.25 \\
0.00 \\
0.00 \\
14.09 \\
0.071\end{array}$ \\
\hline
\end{tabular}

Unheated subfloors start here.

Insulation R-value $=18$

Roll insulation $=11$

Batt insulation $=7$

Fraction of floor area

Constant R-value

Roll insulation

Floor joists $(2 \times 6)$

Air space above roll

Batt insulation

Air space above batt

Total path R-value

Path U-value

Floor U-value $=0.046$

\begin{tabular}{|c|c|c|c|}
\hline \multicolumn{2}{|c|}{ Frame } & \multicolumn{2}{|c|}{ Non-Frame } \\
\hline \multicolumn{2}{|c|}{ Insulation } & \multicolumn{2}{|c|}{ Insulation } \\
\hline Full & Partial & Full & Partial \\
\hline $5.0 \%$ & $5.0 \%$ & $45.0 \%$ & $45 . \overline{0 \%}$ \\
\hline 3.66 & 3.66 & 3.66 & 3.66 \\
\hline 11.00 & 2.75 & 11.00 & 9.63 \\
\hline 6.88 & 6.88 & 0.00 & 0.00 \\
\hline 1.14 & 0.00 & $1.14(a)$ & 0.00 \\
\hline 0.00 & 0.00 & 7.00 & .00 \\
\hline 0.00 & 0.00 & 1.14 & $02(b)$ \\
\hline 22.68 & 13.29 & 23.94 & 21.31 \\
\hline 0.044 & 0.0 & 0.042 & 0.047 \\
\hline
\end{tabular}

(a) R-11 roll insulation is 3.5 inches thick, with a 2.5 inch air space above the roll in the middle section. The middle section insulation was assumed to drop at least 6 inches below the bottom of the floor joists.

(b) When compressed between floor joists three-quarters of the 3.5 inches of insulation (2.6 inches) is estimated to extend into the joists, leaving a 2.9 inch air space. R-7 batt insulation is 2.23 inches thick. This was approximated by eliminating the air space above the batt in the compressed area, but leaving a 0.6 inch air space above the batt insulation. 
Insulation R-value $=22$

Roll insulation $=11$

Batt insulation $=11$

Fraction of floor area

Constant R-value

Roll insulation

Floor joists $(2 \times 6)$

Air space above roll

Batt insulation

Air space above batt

Total path R-value

Path U-value

\begin{tabular}{|c|c|c|c|}
\hline \multicolumn{2}{|c|}{ Frame } & \multicolumn{2}{|c|}{ Non-Frame } \\
\hline \multicolumn{2}{|c|}{ Insulation } & \multicolumn{2}{|c|}{ Insulation } \\
\hline Full & Partial & Full & Partial \\
\hline $5.0 \%$ & $5.0 \%$ & $45.0 \%$ & $45.0 \%$ \\
\hline 3.66 & 3.66 & 3.66 & 3.66 \\
\hline 11.00 & 2.75 & 11.00 & 9.63 \\
\hline 6.88 & 6.88 & 0.00 & 0.00 \\
\hline 1.14 & 0.00 & 1.14 & 0.00 \\
\hline 0.00 & 0.00 & 11.00 & $.90(a)$ \\
\hline 0.00 & 0.00 & 1.14 & 0.00 \\
\hline 22.68 & 13.29 & 27.94 & 23.19 \\
\hline 0.044 & 0.075 & 0.036 & 0.043 \\
\hline
\end{tabular}

Floor U-value $=0.041$

(a) The R-11 roll is 3.5 inches thick; and $75 \%$ (2.6 inches) of it was estimated to extend between the floor joists. The R-11 batt insulation was 3.5 inches, which would leave 6.1 inches $(2.6+3.5)$ of insulation in a 5.5 inch space between the joists. This was approximated by a compression of $17 \%$, which is estimated to cause a reduction of the batt insulation R-value by $10 \%$. 


\section{WINDOW U-VALUES}

Based on a survey of industry practices, the windows in Table 8.6 were identified as representing the range of windows generally used in the industry. The window U-values are based on the 1989 ASHRAE Fundamentals Handbook. A11 multi-pane windows assumed a $1 / 4$ inch air space, which is most common in the industry.

TABLE B.6. Window U-values

\begin{tabular}{|c|c|}
\hline U-value (a) & Window \\
\hline 1.20 & single-pane, aluminum \\
\hline 1.20 & single-pane, aluminum, with tint (b) \\
\hline 0.85 & single-pane, aluminum, storm (c) \\
\hline 0.85 & double-pane, aluminum \\
\hline 0.65 & double-pane, aluminum, thermal break \\
\hline 0.73 & double-pane, aluminum, storm \\
\hline 0.51 & double-pane, wood (d) \\
\hline 0.51 & double-pane, vinyl \\
\hline
\end{tabular}

(a) The 1989 ASHRAE Fundamentals Handbook (Table 13, page 27.16) gives the values for typical residential windows used here. Because the optimization was an annual energy calculation rather than a peak load calculation, these values were converted from $15 \mathrm{mph}$ to a $7.5 \mathrm{mph}$ wind based on the 1989 ASHRAE Fundamentals Handbook, Table 14, page 27.18, with extrapolation from stated values. The $7.5 \mathrm{mph}$ wind is generally a more appropriate assumption for an annual energy calculation (ASHRAE 1989, pages 28.3 and 27.17).

(b) The shading coefficient was 0.83 .

(c) As suggested in 1989 ASHRAE Fundamentals Handbook, storm windows were treated as an additional pane of glass (ASHRAE 1989, p. 27.18). The Uvalues for storm windows were; therefore, taken from the same table as the other windows.

(d) Wood and vinyl window U-values are the same in the ASHRAE 1989 Fundamentals Handbook (ASHRAE 1989, page 27.16). 
DOOR U-VALUES

Based on the PNL survey of the industry, the types of doors in Table B.7 were identified as representing the doors generally used in the industry.

TABLE B.7. Door U-values(a)

$\begin{array}{ll}\frac{\text { U-value }}{0.18} & \text { Door } \\ & \text { metal with thermal break (solid urethane foam core with } \\ 0.28 & \text { metal with storm } \\ 0.39 & \text { metal (solid urethane foam core without thermal break) } \\ 0.15 & \text { metal with thermal break and storm } \\ 0.45 & \text { wood (hollow core flush door) } \\ 0.31 & \text { wood with storm (hollow core flush door with storm) }\end{array}$

\section{REFERENCES}

American Society of Heating, Refrigerating, and Air-Conditioning Engineers, Inc. (ASHRAE). 1986. ASHRAE Handbook 1985 Fundamentals. Atlanta, Georgia.

American Society of Heating, Refrigerating, and Air-Conditioning Engineers, Inc. (ASHRAE). 1989. ASHRAE Handbook 1989 Fundamentals. Atlanta, Georgia.

24 CFR 3280. 1987. U.S. Department of Housing and Urban Development. "Manufactured Home Construction and Safety Standards." U.S. Code of Federal Regulations.

(a) A11 door U-values were taken from Tables 5A and 5B, 1985 ASHRAE Fundamentals Handbook, page 23.15. The type of door is shown in parenthes is. The value for storm doors was extrapolated from the same tables. 
APPENDIX C

CITIES USED IN U-VALUE OPTIMIZATION 


\section{CITIES USED IN U-VALUE OPTIMIZATION}

The U-value optimums were generated for the following 881 cities using ARES. (ARES is described in Chapter 2.) This list includes all the cities included in the ARES data base. For each city, five different equipment/fuel types were run for both single- and double-wide homes.

\begin{tabular}{|c|c|c|c|}
\hline $\begin{array}{l}\text { Alabama } \\
\text { Andalusia } \\
\text { Dothan } \\
\text { Mobile } \\
\text { Selma }\end{array}$ & $\begin{array}{l}\text { Anniston } \\
\text { Eufaula } \\
\text { Montgomery } \\
\text { Talladega }\end{array}$ & $\begin{array}{l}\text { Auburn } \\
\text { Gadsden } \\
\text { Ozark } \\
\text { Tuscaloosa }\end{array}$ & $\begin{array}{l}\text { Birmingham } \\
\text { Huntsville } \\
\text { Scottsboro }\end{array}$ \\
\hline$\frac{\text { Alaska }}{\text { Anchorage }}$ & Fairbanks & Juneau & Kenai \\
\hline $\begin{array}{l}\text { Arizona } \\
\text { Casa Grande } \\
\text { Nogales } \\
\text { Tucson }\end{array}$ & $\begin{array}{l}\text { Douglas } \\
\text { Phoenix } \\
\text { Yuma }\end{array}$ & $\begin{array}{l}\text { Flagstaff } \\
\text { Prescott }\end{array}$ & $\begin{array}{l}\text { Mesa } \\
\text { Tempe }\end{array}$ \\
\hline $\begin{array}{l}\text { Arkansas } \\
\text { Arkadelphia } \\
\text { Conway } \\
\text { Hope } \\
\text { Magnolia } \\
\text { Pine Bluff } \\
\text { Texarkana }\end{array}$ & $\begin{array}{l}\text { Benton } \\
\text { El Dorado } \\
\text { Hot Springs } \\
\text { Malvern } \\
\text { Russellville }\end{array}$ & $\begin{array}{l}\text { Blytheville } \\
\text { Fayetteville } \\
\text { Jonesboro } \\
\text { No. Little Rock } \\
\text { Searcy }\end{array}$ & $\begin{array}{l}\text { Camden } \\
\text { Fort Smith } \\
\text { Little Rock } \\
\text { Paragould } \\
\text { Stuttgart }\end{array}$ \\
\hline $\begin{array}{l}\text { California } \\
\text { Antioch } \\
\text { Burbank } \\
\text { Concord } \\
\text { E1 Centro } \\
\text { Fontana } \\
\text { Laguna Beach } \\
\text { Lodi } \\
\text { Los Banos } \\
\text { Modesto } \\
\text { Oakland } \\
\text { Palo ATto } \\
\text { Porterville } \\
\text { Richmond } \\
\text { San Bernardino } \\
\text { San Jose } \\
\text { Santa Barbara }\end{array}$ & $\begin{array}{l}\text { Bakersfield } \\
\text { Chico } \\
\text { Corona } \\
\text { Escondido } \\
\text { Fresno } \\
\text { La Mesa } \\
\text { Lompoc } \\
\text { Los Gatos } \\
\text { Monterey } \\
\text { Oceanside } \\
\text { Pasadena } \\
\text { Redding } \\
\text { Riverside } \\
\text { San Diego } \\
\text { San Luis Obispo } \\
\text { Santa Cruz }\end{array}$ & $\begin{array}{l}\text { Barstow } \\
\text { Chula Vista } \\
\text { Culver City } \\
\text { Eureka } \\
\text { Hanford } \\
\text { Lancaster } \\
\text { Long Beach } \\
\text { Madera } \\
\text { Napa } \\
\text { Oxnard } \\
\text { Petaluma } \\
\text { Redlands } \\
\text { Sacramento } \\
\text { San Francisco } \\
\text { San Rafael } \\
\text { Santa Maria }\end{array}$ & $\begin{array}{l}\text { Berkeley } \\
\text { Claremont } \\
\text { Davis } \\
\text { Fairfield } \\
\text { Indio } \\
\text { Livermore } \\
\text { Los Angeles } \\
\text { Merced } \\
\text { Newport Beach } \\
\text { Palm Springs } \\
\text { Pomona } \\
\text { Redwood City } \\
\text { Salinas } \\
\text { San Gabriel } \\
\text { Santa Ana } \\
\text { Santa Monica }\end{array}$ \\
\hline
\end{tabular}

$$
\text { C. } 1
$$




\begin{tabular}{|c|c|c|c|}
\hline $\begin{array}{l}\text { Santa Paula } \\
\text { Tracy } \\
\text { Visalia }\end{array}$ & $\begin{array}{l}\text { Santa Rosa } \\
\text { Tustin } \\
\text { Watsonville }\end{array}$ & $\begin{array}{l}\text { Stockton } \\
\text { Upl and } \\
\text { Woodl and }\end{array}$ & $\begin{array}{l}\text { Torrance } \\
\text { Vacaville } \\
\text { Yorba Linda }\end{array}$ \\
\hline $\begin{array}{l}\text { Colorado } \\
\text { Boulder } \\
\text { Durango } \\
\text { Lakewood }\end{array}$ & $\begin{array}{l}\text { Canon City } \\
\text { Fort Collins } \\
\text { Longmont }\end{array}$ & $\begin{array}{l}\text { Colorado Springs } \\
\text { Grand Junction } \\
\text { Pueblo }\end{array}$ & $\begin{array}{l}\text { Denver } \\
\text { Greeley } \\
\text { Sterling }\end{array}$ \\
\hline $\begin{array}{l}\text { Connecticut } \\
\text { Bridgeport } \\
\text { Hartford } \\
\text { Norwalk }\end{array}$ & $\begin{array}{l}\text { Danbury } \\
\text { Meriden } \\
\text { Storrs }\end{array}$ & $\begin{array}{l}\text { Enfield } \\
\text { Middletown } \\
\text { Waterbury }\end{array}$ & $\begin{array}{l}\text { Groton } \\
\text { New Haven }\end{array}$ \\
\hline$\frac{\text { Delaware }}{\text { Dover }}$ & Newark & Wilmington & \\
\hline \multicolumn{4}{|c|}{$\frac{\text { District of Columbia }}{\text { Washington }}$} \\
\hline $\begin{array}{l}\text { Florida } \\
\text { Bartow } \\
\text { Daytona Beach } \\
\text { Fort Pierce } \\
\text { Jacksonville } \\
\text { Miami } \\
\text { Palatka } \\
\text { St. Petersburg } \\
\text { Tampa } \\
\text { Winter Haven }\end{array}$ & $\begin{array}{l}\text { Belle Glade } \\
\text { Deland } \\
\text { Gainesville } \\
\text { Key West } \\
\text { Naples } \\
\text { Pensacola } \\
\text { Sanford } \\
\text { Titusville }\end{array}$ & $\begin{array}{l}\text { Bradenton } \\
\text { Fort Lauderdale } \\
\text { Hialeah } \\
\text { Lakeland } \\
\text { Ocala } \\
\text { Plant City } \\
\text { Sarasota } \\
\text { Vero Beach }\end{array}$ & $\begin{array}{l}\text { Clearwater } \\
\text { Fort Myers } \\
\text { Homestead } \\
\text { Melbourne } \\
\text { Orlando } \\
\text { Pompano Beach } \\
\text { Tallahassee } \\
\text { West Palm Beach }\end{array}$ \\
\hline $\begin{array}{l}\text { Georgia } \\
\text { Albany } \\
\text { Augusta } \\
\text { Covington } \\
\text { Fitzgerald } \\
\text { Milledgeville } \\
\text { Savannah }\end{array}$ & $\begin{array}{l}\text { Americus } \\
\text { Brunswick } \\
\text { Dalton } \\
\text { Gainesville } \\
\text { Moultrie } \\
\text { Thomasville }\end{array}$ & $\begin{array}{l}\text { Athens } \\
\text { Carroliton } \\
\text { Douglas } \\
\text { La Grange } \\
\text { Newnan } \\
\text { Tifton }\end{array}$ & $\begin{array}{l}\text { Atlanta } \\
\text { Columbus } \\
\text { Dublin } \\
\text { Macon } \\
\text { Rome } \\
\text { Waycross }\end{array}$ \\
\hline $\begin{array}{l}\text { Hawaji } \\
\text { Lilo } \\
\text { Lahaina }\end{array}$ & Honolulu & Kahului & Kaneohe Mauka \\
\hline $\begin{array}{l}\text { Idaho } \\
\text { Boise } \\
\text { Moscow }\end{array}$ & $\begin{array}{l}\text { Caldwell } \\
\text { Pocatello }\end{array}$ & Coeur D'Alene & Idaho Falls \\
\hline $\begin{array}{l}\text { Illinois } \\
\text { Alton } \\
\text { Carbondale } \\
\text { Danville } \\
\text { Effingham }\end{array}$ & $\begin{array}{l}\text { Aurora } \\
\text { Champaign } \\
\text { Decatur } \\
\text { Elgin }\end{array}$ & $\begin{array}{l}\text { Betleville } \\
\text { Charleston } \\
\text { De Kalb } \\
\text { Galesburg }\end{array}$ & $\begin{array}{l}\text { Bloomington } \\
\text { Chicago } \\
\text { Dixon } \\
\text { Jacksonville }\end{array}$ \\
\hline & & & \\
\hline
\end{tabular}




\begin{tabular}{|c|c|c|c|}
\hline $\begin{array}{l}\text { Joliet } \\
\text { Monmouth } \\
\text { Peoria } \\
\text { Rantoul } \\
\text { Waukegan }\end{array}$ & $\begin{array}{l}\text { Kewanee } \\
\text { Mount Vernon } \\
\text { Peru } \\
\text { Rockford } \\
\text { Wheaton }\end{array}$ & $\begin{array}{l}\text { Lincoln } \\
\text { Ottawa } \\
\text { Pontiac } \\
\text { Springfield }\end{array}$ & $\begin{array}{l}\text { Mattoon } \\
\text { Park Forest } \\
\text { Quincy } \\
\text { Urbana }\end{array}$ \\
\hline $\begin{array}{l}\text { Indiana } \\
\text { Anderson } \\
\text { Elwood } \\
\text { Gary } \\
\text { Huntington } \\
\text { Lafayette } \\
\text { New Castle } \\
\text { South Bend } \\
\text { Wabash }\end{array}$ & $\begin{array}{l}\text { Bloomington } \\
\text { Evansville } \\
\text { Goshen } \\
\text { Indianapolis } \\
\text { Marion } \\
\text { Richmond } \\
\text { Terre Haute } \\
\text { West Lafayette }\end{array}$ & $\begin{array}{l}\text { Columbus } \\
\text { Fort Wayne } \\
\text { Greenfield } \\
\text { Kokomo } \\
\text { Martinsville } \\
\text { Seymour } \\
\text { Valparaiso }\end{array}$ & $\begin{array}{l}\text { Crawfordsville } \\
\text { Frankfort } \\
\text { Hobart } \\
\text { La Porte } \\
\text { Muncie } \\
\text { Shelbyville } \\
\text { Vincennes }\end{array}$ \\
\hline $\begin{array}{l}\frac{\text { Iowa }}{\text { Ames }} \\
\text { Clinton } \\
\text { Fort Dodge } \\
\text { Marshall town } \\
\text { Oskaloosa } \\
\text { Waterloo }\end{array}$ & $\begin{array}{l}\text { Ankeny } \\
\text { Davenport } \\
\text { Indianola } \\
\text { Mason City } \\
\text { Otturnwa }\end{array}$ & $\begin{array}{l}\text { Boone } \\
\text { Des Moines } \\
\text { Iowa City } \\
\text { Muscatine } \\
\text { Sioux City }\end{array}$ & $\begin{array}{l}\text { Cedar Rapids } \\
\text { Dubuque } \\
\text { Keokuk } \\
\text { Newton } \\
\text { Spencer }\end{array}$ \\
\hline $\begin{array}{l}\text { Kansas } \\
\text { Hutchinson } \\
\text { Olathe } \\
\text { Topeka }\end{array}$ & $\begin{array}{l}\text { Manhattan } \\
\text { Ottawa } \\
\text { Wichita }\end{array}$ & $\begin{array}{l}\text { McPherson } \\
\text { Parsons } \\
\text { Winfield }\end{array}$ & $\begin{array}{l}\text { Newton } \\
\text { Salina }\end{array}$ \\
\hline $\begin{array}{l}\text { Kentucky } \\
\text { Ashland } \\
\text { Henderson } \\
\text { Madisonvilie } \\
\text { Owensboro }\end{array}$ & $\begin{array}{l}\text { Bowling Green } \\
\text { Hopkinsville } \\
\text { Mayfield } \\
\text { Paducah }\end{array}$ & $\begin{array}{l}\text { Covington } \\
\text { Lexington } \\
\text { Middlesboro } \\
\text { Somerset }\end{array}$ & $\begin{array}{l}\text { Frankfort } \\
\text { Louisville } \\
\text { Murray }\end{array}$ \\
\hline $\begin{array}{l}\text { Louisiana } \\
\text { Alexandria } \\
\text { Hammond } \\
\text { Lake Charles } \\
\text { Natchitoches } \\
\text { Shreveport }\end{array}$ & $\begin{array}{l}\text { Bastrop } \\
\text { Houma } \\
\text { Minden } \\
\text { New Iberia } \\
\text { Tallulah }\end{array}$ & $\begin{array}{l}\text { Baton Rouge } \\
\text { Jennings } \\
\text { Monroe } \\
\text { New Orleans }\end{array}$ & $\begin{array}{l}\text { Bogalusa } \\
\text { Lafayette } \\
\text { Morgan City } \\
\text { Ruston }\end{array}$ \\
\hline $\begin{array}{l}\text { Maine } \\
\text { Augusta } \\
\text { Presque Isle }\end{array}$ & $\begin{array}{l}\text { Bangor } \\
\text { Waterville }\end{array}$ & Lewiston & Portland \\
\hline $\begin{array}{l}\text { Maryland } \\
\text { Baltimore } \\
\text { Hagerstown }\end{array}$ & $\begin{array}{l}\text { Cambridge } \\
\text { Laurel }\end{array}$ & $\begin{array}{l}\text { College Park } \\
\text { Rockville }\end{array}$ & $\begin{array}{l}\text { Cumberland } \\
\text { Salisbury }\end{array}$ \\
\hline$\frac{\text { Massachusetts }}{\text { Amherst }}$ & Boston & Brockton & Clinton \\
\hline
\end{tabular}




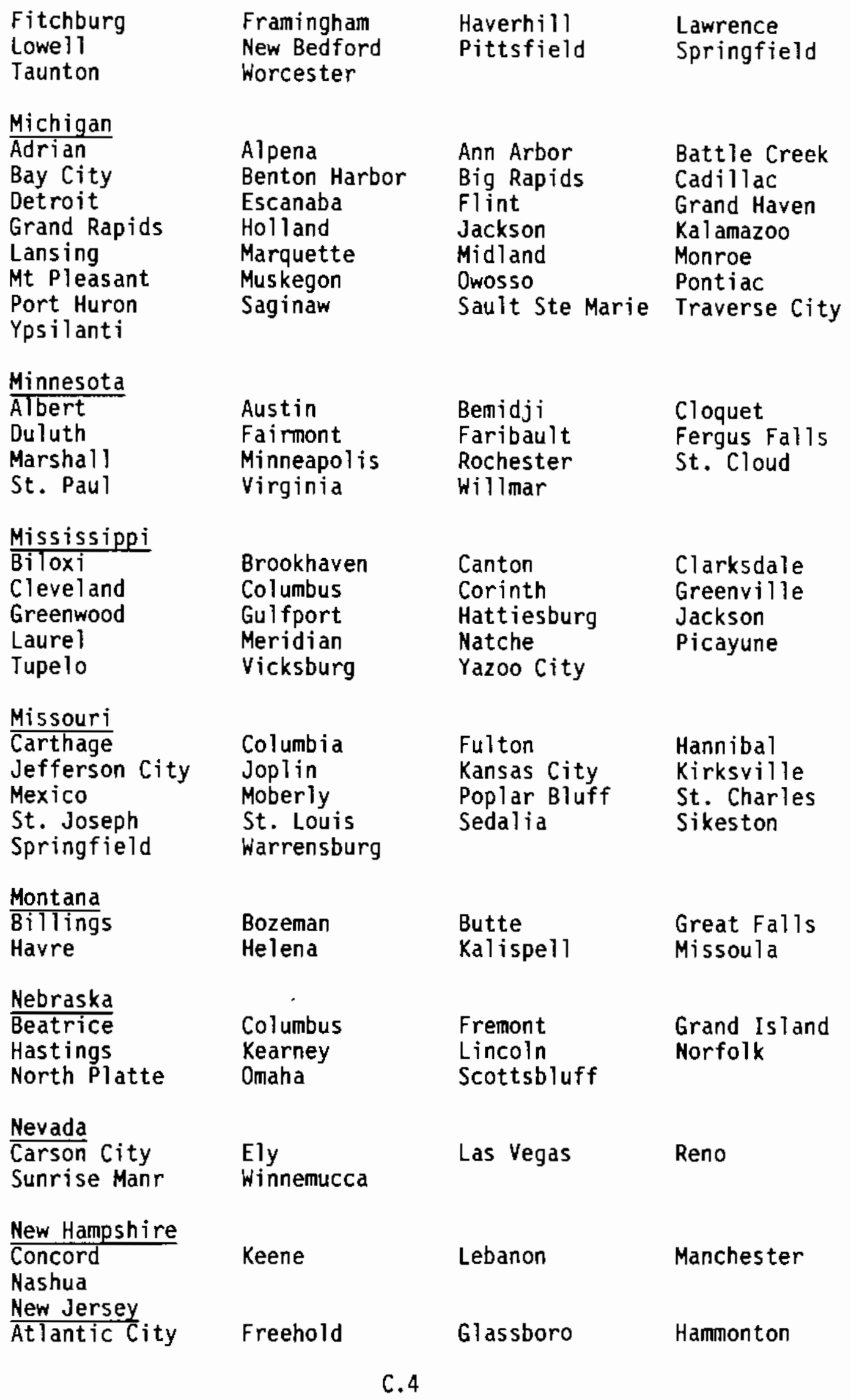




\begin{tabular}{|c|c|c|c|}
\hline $\begin{array}{l}\text { Jersey City } \\
\text { Moorestown } \\
\text { Plainfield }\end{array}$ & $\begin{array}{l}\text { Little Falls } \\
\text { Newark } \\
\text { Somerville }\end{array}$ & $\begin{array}{l}\text { Long Branch } \\
\text { New Brunswick } \\
\text { Trenton }\end{array}$ & $\begin{array}{l}\text { Millville } \\
\text { Paterson } \\
\text { Vineland }\end{array}$ \\
\hline $\begin{array}{l}\text { New Mexico } \\
\text { Alamogordo } \\
\text { Clovis } \\
\text { Los Alamos }\end{array}$ & $\begin{array}{l}\text { Albuquerque } \\
\text { Gallup } \\
\text { Roswell }\end{array}$ & $\begin{array}{l}\text { Artesia } \\
\text { Hobbs } \\
\text { Santa Fe }\end{array}$ & $\begin{array}{l}\text { Carlsbad } \\
\text { Las Cruces }\end{array}$ \\
\hline $\begin{array}{l}\text { New York } \\
\text { Albany } \\
\text { Canandaigua } \\
\text { Fredonia } \\
\text { Lockport } \\
\text { Ogdensburg } \\
\text { Rochester } \\
\text { Syracuse }\end{array}$ & $\begin{array}{l}\text { Batavia } \\
\text { Cortland } \\
\text { Geneva } \\
\text { Massena } \\
\text { Oswego } \\
\text { Rome } \\
\text { Utica }\end{array}$ & $\begin{array}{l}\text { Binghamton } \\
\text { Dobbs Ferry } \\
\text { Gloversville } \\
\text { Mineola } \\
\text { Patchogue } \\
\text { Scarsdale } \\
\text { Watertown }\end{array}$ & $\begin{array}{l}\text { Buffalo } \\
\text { Elmira } \\
\text { Ithaca } \\
\text { New York } \\
\text { Poughkeepsie } \\
\text { Schenectady }\end{array}$ \\
\hline $\begin{array}{l}\text { North Carolina } \\
\text { Albemarle } \\
\text { Burlington } \\
\text { Durham } \\
\text { Goldsboro } \\
\text { Kinston } \\
\text { Lumberton } \\
\text { Raleigh } \\
\text { Shelby } \\
\text { Winston-Salem }\end{array}$ & $\begin{array}{l}\text { Asheboro } \\
\text { Chapel Hill } \\
\text { Elizabeth City } \\
\text { Greensboro } \\
\text { Laurinburg } \\
\text { Monroe } \\
\text { Reidsville } \\
\text { Statesville }\end{array}$ & $\begin{array}{l}\text { Asheville } \\
\text { Charlotte } \\
\text { Fayetteville } \\
\text { Hickory } \\
\text { Lenoir } \\
\text { Morganton } \\
\text { Rocky Mount } \\
\text { Wilmington }\end{array}$ & $\begin{array}{l}\text { Boone } \\
\text { Concord } \\
\text { Gastonia } \\
\text { High Point } \\
\text { Lexington } \\
\text { New Bern } \\
\text { Salisbury } \\
\text { Wilson }\end{array}$ \\
\hline $\begin{array}{l}\text { North Dakota } \\
\text { Bismarck } \\
\text { Mandan }\end{array}$ & $\begin{array}{l}\text { Dickinson } \\
\text { Minot }\end{array}$ & $\begin{array}{l}\text { Grand Forks } \\
\text { Williston }\end{array}$ & Jamestown \\
\hline $\begin{array}{l}\text { Ohio } \\
\text { Akron } \\
\text { Bellefontaine } \\
\text { Canton } \\
\text { Columbus } \\
\text { Delaware } \\
\text { Greenville } \\
\text { Lima } \\
\text { Norwalk } \\
\text { Steubenville } \\
\text { Van Wert } \\
\text { Wooster }\end{array}$ & $\begin{array}{l}\text { Ashland } \\
\text { Bowling Green } \\
\text { Cincinnati } \\
\text { Coshocton } \\
\text { Dover } \\
\text { Hamilton } \\
\text { Mansfield } \\
\text { Painesville } \\
\text { Tiffin } \\
\text { Warren } \\
\text { Xenia }\end{array}$ & $\begin{array}{l}\text { Ashtabula } \\
\text { Bucyrus } \\
\text { Circleville } \\
\text { Dayton } \\
\text { Elyria } \\
\text { Ironton } \\
\text { Middletown } \\
\text { Portsmouth } \\
\text { Toledo } \\
\text { Washington } \\
\text { Youngstown }\end{array}$ & $\begin{array}{l}\text { Athens } \\
\text { Cambridge } \\
\text { Cleveland } \\
\text { Defiance } \\
\text { Findlay } \\
\text { Lancaster } \\
\text { Newark } \\
\text { Sandusky } \\
\text { Urbana } \\
\text { Wilmington } \\
\text { Zanesville }\end{array}$ \\
\hline $\begin{array}{l}\text { Oklahoma } \\
\text { Ada } \\
\text { Chickasha } \\
\text { Enid } \\
\text { Miami } \\
\text { Stillwater }\end{array}$ & $\begin{array}{l}\text { Altus } \\
\text { Claremore } \\
\text { Guthrie } \\
\text { Oklahoma City } \\
\text { Tulsa }\end{array}$ & $\begin{array}{l}\text { Ardmiore } \\
\text { Duncan } \\
\text { Lawton } \\
\text { Okmulgee } \\
\text { Woodward }\end{array}$ & $\begin{array}{l}\text { Bartlesville } \\
\text { El Reno } \\
\text { McAlester } \\
\text { Ponca City }\end{array}$ \\
\hline
\end{tabular}


Oregon

Ashland

Forest Grove

Mc Minnville

Portland

Pennsylvania

ATlentown

Coatesville

Indiana

New Castle

Reading

West Chester

Rhode Is land

Providence

South Carolina

Aiken

Conway

Greenwood

Union

South Dakota

Aberdeen

Pjerre

Yankton

Tennessee

Bristol

Dyersburg

Kingsport

Murfreesboro

Shelbyville

Texas

Abilene

Austin

Big Spring

Brownwood

College Station

Del Rio

Fort Worth

Harlingen

Huntsville

Laredo

Midland

Palestine

Port Lavaca

Snyder

Tyler
Bend

Grants Pass

Medford

Roseburg

Bradford

Erie

Johns town

Philadelphia

Scranton

Wilkes-Barre

Woonsocket

Anderson

Florence

Laurens

Brookings

Rapid City

Chattanooga

Franklin

Knoxville

Nashville

Springfield

Alice

Bay City

Borger

Bryan

Corpus Christi

Denison

Gainesville

Henderson

Killeen

Lufkin

Mineral Wells

Paris

San Angelo

Sulphur Springs

Uvalde
Corvallis

Klamath Falls

Oregon City

Salem

Carlisle

Hanover

Lancaster

Phoenixville

Uniontown

Williamsport
Eugene

La Grande

Pendleton

Chambersburg

Harrisburg

Meadville

Pittsburgh

Warren

York
Charleston

Georgetown

Orangeburg

Huron

Sioux Falls

Clarksville

Greeneville

Mc Minnville

Oak Ridge

Tullahoma

Amarilio

Beaumont

Brenham

Canyon

Corsicana

Denton

Galveston

Hereford

Kingsville

Marshall

Mount Pleasant

Plainview

San Antonio

Taylor

Vernon
Columb $i a$

Greenvilie

Sumter

Mitchell

Watertown

Columbia

Jackson

Memph is

Paris

Union City

Angleton

Beeville

Brownsville

Cleburne

Dallas

El Paso

Greenville

Houston

Lamesa

Mc Allen

Odessa

Port Arthur

San Marcos

Temple

Victoria 


\begin{tabular}{|c|c|c|c|}
\hline $\begin{array}{l}\text { Waco } \\
\text { Wichita Falls }\end{array}$ & Waxahachie & Weatherford & Wes laco \\
\hline $\begin{array}{l}\text { Utah } \\
\text { Cedar City } \\
\text { Saint George }\end{array}$ & $\begin{array}{l}\text { Logan } \\
\text { Salt Lake City }\end{array}$ & $\begin{array}{l}\text { Ogden } \\
\text { Tooele }\end{array}$ & Provo \\
\hline$\frac{\text { Vermont }}{\text { Burlington }}$ & Rutland & & \\
\hline $\begin{array}{l}\text { Virgina } \\
\text { Blacksburg } \\
\text { Hopewel ? } \\
\text { Norfolk } \\
\text { Suffolk }\end{array}$ & $\begin{array}{l}\text { Charlottesville } \\
\text { Lynchburg } \\
\text { Richmond } \\
\text { Winchester }\end{array}$ & $\begin{array}{l}\text { Danville } \\
\text { Martinsville } \\
\text { Roanoke }\end{array}$ & $\begin{array}{l}\text { Fredericksburg } \\
\text { Newport } \\
\text { Staunton }\end{array}$ \\
\hline $\begin{array}{l}\text { Washington } \\
\text { Aberdeen } \\
\text { Everett } \\
\text { Moses Lake } \\
\text { Puyallup } \\
\text { Tacoma } \\
\text { Yakima }\end{array}$ & $\begin{array}{l}\text { Bellingham } \\
\text { Kennewick } \\
\text { 0lympia } \\
\text { Richland } \\
\text { Vancouver }\end{array}$ & $\begin{array}{l}\text { Bremerton } \\
\text { Kent } \\
\text { Port Angeles } \\
\text { Seatt le } \\
\text { Walla Walla }\end{array}$ & $\begin{array}{l}\text { Centralia } \\
\text { Longview } \\
\text { Pullman } \\
\text { Spokane } \\
\text { Wenatchee }\end{array}$ \\
\hline $\begin{array}{l}\text { West Virgina } \\
\text { Beckley } \\
\text { Fairmont } \\
\text { Parkersburg }\end{array}$ & $\begin{array}{l}\text { Bluefield } \\
\text { Hunt ington } \\
\text { Wheeling }\end{array}$ & $\begin{array}{l}\text { Charleston } \\
\text { Martinsburg }\end{array}$ & $\begin{array}{l}\text { Clarksburg } \\
\text { Morgantown }\end{array}$ \\
\hline $\begin{array}{l}\text { Wisconsin } \\
\text { Appleton } \\
\text { Germantown } \\
\text { La Crosse } \\
\text { Marshfield } \\
\text { Sheboygan } \\
\text { Watertown } \\
\text { Whitewater }\end{array}$ & $\begin{array}{l}\text { Beloit } \\
\text { Green Bay } \\
\text { Madison } \\
\text { Milwaukee } \\
\text { Stevens Point } \\
\text { Waukesha } \\
\text { Wisconsin Rapids }\end{array}$ & $\begin{array}{l}\text { Eau Claire } \\
\text { Janesville } \\
\text { Manitowoc } \\
\text { Oshkosh } \\
\text { Superior } \\
\text { Wausau }\end{array}$ & $\begin{array}{l}\text { Fond Du Lac } \\
\text { Kenosha } \\
\text { Marinette } \\
\text { Racine } \\
\text { Two Rivers } \\
\text { West Allis }\end{array}$ \\
\hline $\begin{array}{l}\text { Wyoming } \\
\text { Casper } \\
\text { Laramie }\end{array}$ & $\begin{array}{l}\text { Cheyenne } \\
\text { Rock Springs }\end{array}$ & $\begin{array}{l}\text { Gillette } \\
\text { Sheridan }\end{array}$ & Green River \\
\hline
\end{tabular}



APPENDIX D

OPTIMUM U-VALUES BY STATE 
APPENDIX D

OPTIMUM U-VALUES BY STATE

IABLE D.1. Optimum U-values by State

\begin{tabular}{|c|c|c|c|c|c|}
\hline State & $0 i 1$ & Gas & $L P G$ & Elec & $\begin{array}{l}\text { Heat } \\
\text { Pump }\end{array}$ \\
\hline Al abama & 0.124 & 0.118 & 0.108 & 0.101 & 0.126 \\
\hline Alaska & 0.072 & 0.083 & 0.071 & 0.071 & 0.071 \\
\hline Arizona & 0.092 & 0.096 & 0.088 & 0.078 & 0.091 \\
\hline Arkansas & 0.112 & 0.117 & 0.103 & 0.078 & 0.108 \\
\hline California & 0.106 & 0.110 & 0.091 & 0.080 & 0.107 \\
\hline Colorado & 0.085 & 0.087 & 0.080 & 0.072 & 0.078 \\
\hline Connecticut & 0.079 & 0.079 & 0.074 & 0.071 & 0.079 \\
\hline Delaware & 0.080 & 0.082 & 0.077 & 0.073 & 0.099 \\
\hline Washington D.C. & 0.080 & 0.079 & 0.072 & 0.072 & 0.094 \\
\hline Florida & 0.141 & 0.141 & 0.129 & 0.123 & 0.144 \\
\hline Georgia & 0.116 & 0.116 & 0.102 & 0.097 & 0.126 \\
\hline Hawai i & 0.157 & 0.157 & 0.157 & 0.157 & 0.157 \\
\hline Idaho & 0.079 & 0.079 & 0.072 & 0.074 & 0.096 \\
\hline Illinois & 0.080 & 0.083 & 0.079 & 0.071 & 0.075 \\
\hline Indiana & 0.080 & 0.081 & 0.078 & 0.072 & 0.080 \\
\hline Iowa & 0.079 & 0.081 & 0.078 & 0.071 & 0.074 \\
\hline Kansas & 0.087 & 0.098 & 0.084 & 0.072 & 0.083 \\
\hline Kentucky & 0.102 & 0.108 & 0.079 & 0.078 & 0.110 \\
\hline Louisiana & 0.129 & 0.127 & 0.112 & 0.104 & 0.129 \\
\hline Maine & 0.079 & 0.072 & 0.072 & 0.071 & 0.072 \\
\hline Maryland & 0.080 & 0.083 & 0.076 & 0.072 & 0.091 \\
\hline Massachusetts & 0.079 & 0.079 & 0.074 & 0.072 & 0.077 \\
\hline Michigan & 0.075 & 0.078 & 0.072 & 0.071 & 0.074 \\
\hline Minnesota & 0.072 & 0.074 & 0.072 & 0.071 & 0.072 \\
\hline Mississippi & 0.125 & 0.123 & 0.108 & 0.098 & 0.127 \\
\hline Missouri & 0.088 & 0.096 & 0.085 & 0.072 & 0.083 \\
\hline Montana & 0.078 & 0.078 & 0.073 & 0.072 & 0.077 \\
\hline Nebraska & 0.079 & 0.081 & 0.078 & 0.072 & 0.078 \\
\hline
\end{tabular}

D. 1 
IABLE 0.1. Optimum U-value by State (cont.)

\begin{tabular}{|c|c|c|c|c|c|}
\hline State & $0 i 1$ & Gas & $\mathrm{LPG}$ & Elec & $\begin{array}{l}\text { Heat } \\
\text { Pump }\end{array}$ \\
\hline Nevada & 0.086 & 0.089 & 0.077 & $\overline{0.076}$ & 0.089 \\
\hline New Hampshire & 0.079 & 0.077 & 0.072 & 0.071 & 0.072 \\
\hline New Jersey & 0.081 & 0.082 & 0.074 & 0.072 & 0.079 \\
\hline New Mexico & 0.097 & 0.099 & 0.091 & 0.072 & 0.091 \\
\hline New York & 0.079 & 0.079 & 0.072 & 0.071 & 0.073 \\
\hline North Carolina & 0.108 & 0.110 & 0.090 & 0.083 & 0.119 \\
\hline North Dakota & 0.072 & 0.074 & 0.072 & 0.071 & 0.072 \\
\hline Ohio & 0.080 & 0.080 & 0.073 & 0.072 & 0.080 \\
\hline Oklahoma & 0.106 & 0.110 & 0.095 & 0.075 & 0.105 \\
\hline Oregon & 0.090 & 0.088 & 0.073 & 0.077 & 0.108 \\
\hline Pennsylvania & 0.080 & 0.081 & 0.075 & 0.072 & 0.078 \\
\hline Rhode Is land & 0.079 & 0.079 & 0.074 & 0.072 & 0.079 \\
\hline South Carolina & 0.114 & 0.117 & 0.099 & 0.092 & 0.124 \\
\hline South Dakota & 0.076 & 0.079 & 0.072 & 0.072 & 0.073 \\
\hline Tennessee & 0.114 & 0.118 & 0.084 & 0.087 & 0.124 \\
\hline Texas & 0.122 & 0.123 & 0.111 & 0.101 & 0.123 \\
\hline Utah & 0.079 & 0.082 & 0.077 & 0.071 & 0.079 \\
\hline Vermont & 0.079 & 0.078 & 0.072 & 0.071 & 0.072 \\
\hline Virginia & 0.091 & 0.094 & 0.079 & 0.077 & 0.109 \\
\hline Washington & 0.082 & 0.083 & 0.072 & 0.079 & 0.119 \\
\hline West Virginia & 0.090 & 0.090 & 0.079 & 0.075 & 0.098 \\
\hline Wisconsin & 0.074 & 0.075 & 0.072 & 0.071 & 0.073 \\
\hline Wyoming & 0.079 & 0.079 & 0.077 & 0.072 & 0.07 \\
\hline
\end{tabular}

Figures 0.1 through 0.5 show the optimum U-values from Table 0.1 by state in map form. 


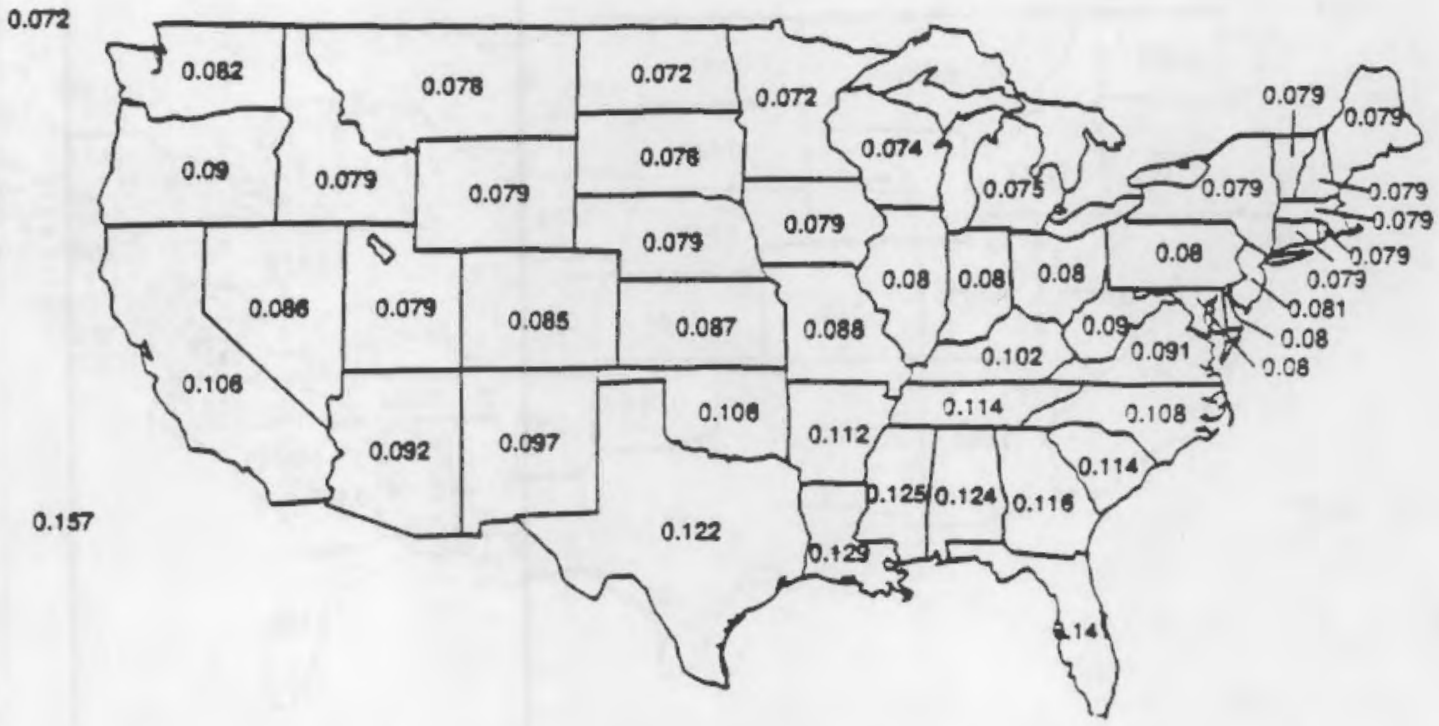

FIGURE D.1. Optimum 0il U-values by State

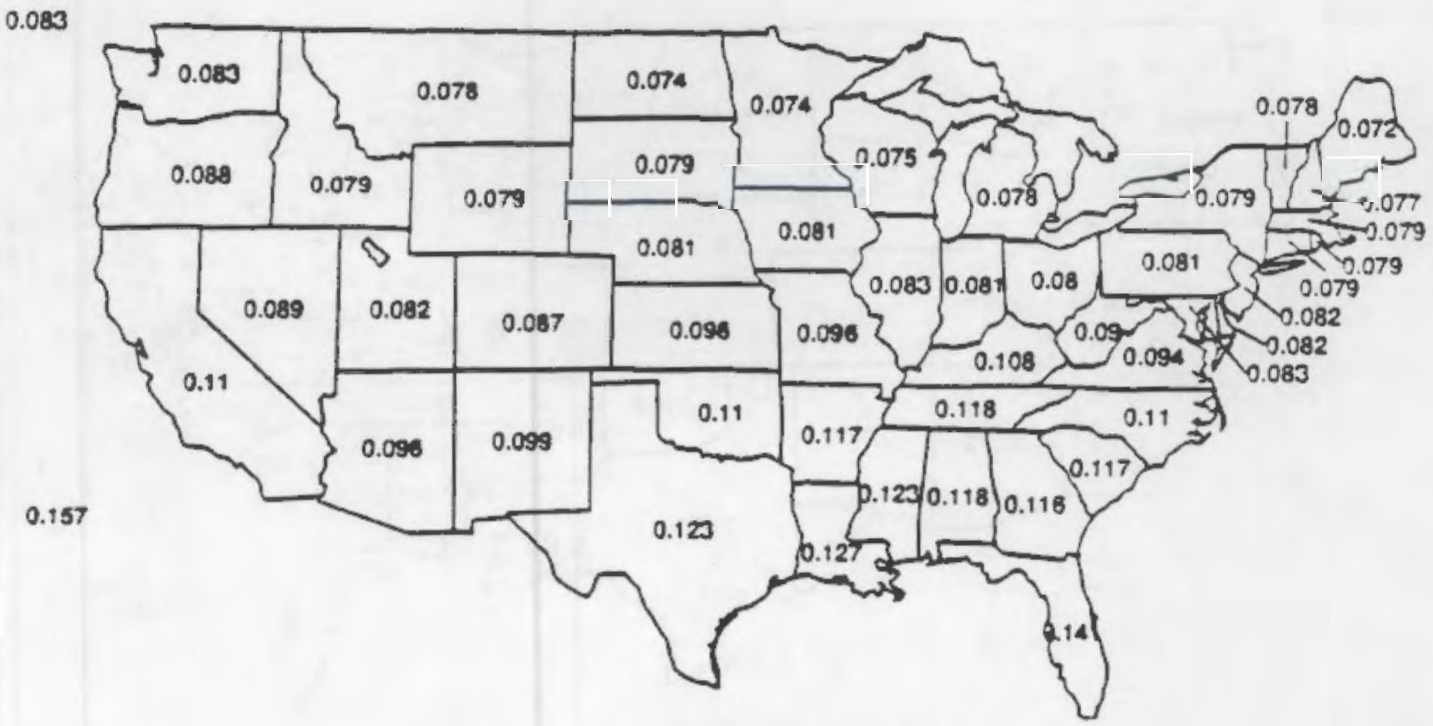

FIGURE D.2. Optimum Gas U-values by State

D.3 


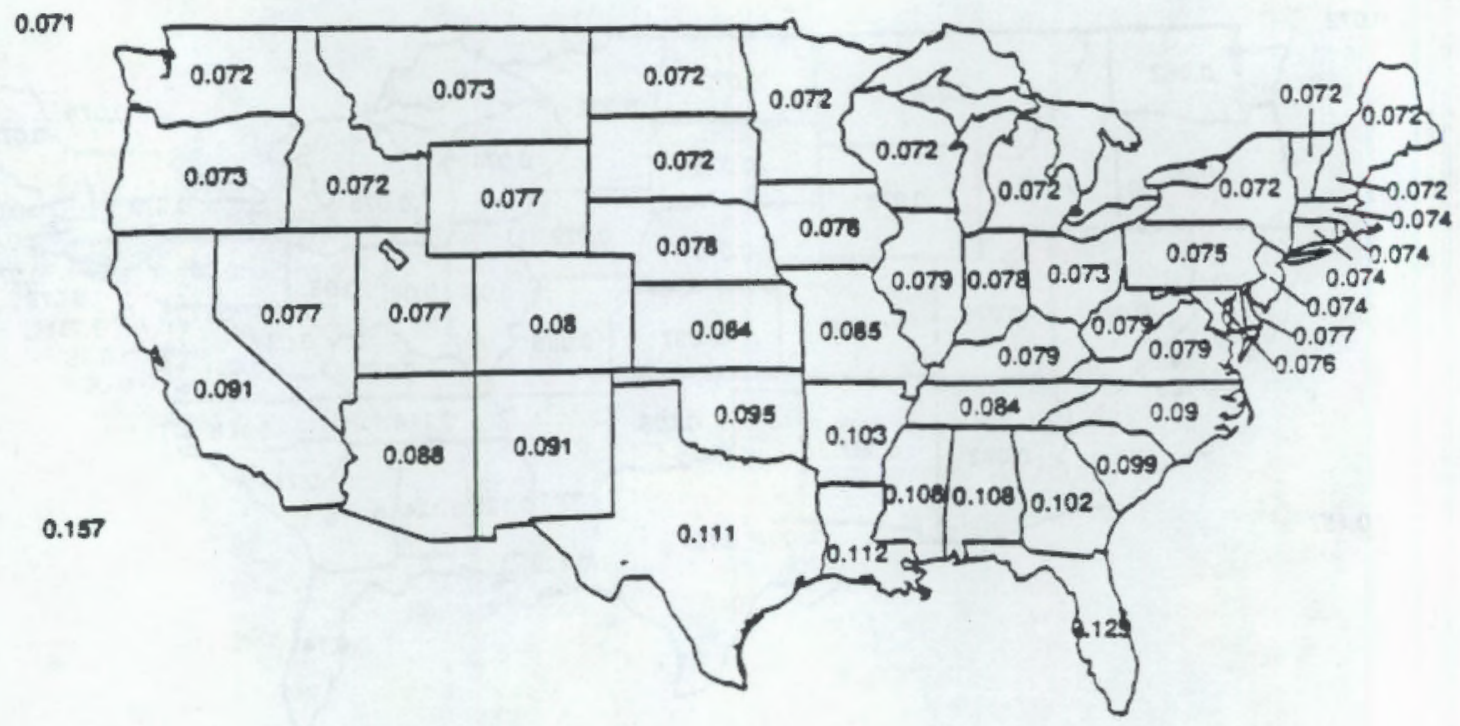

FIGURE 0.3 . Optimum LPG U-values by State

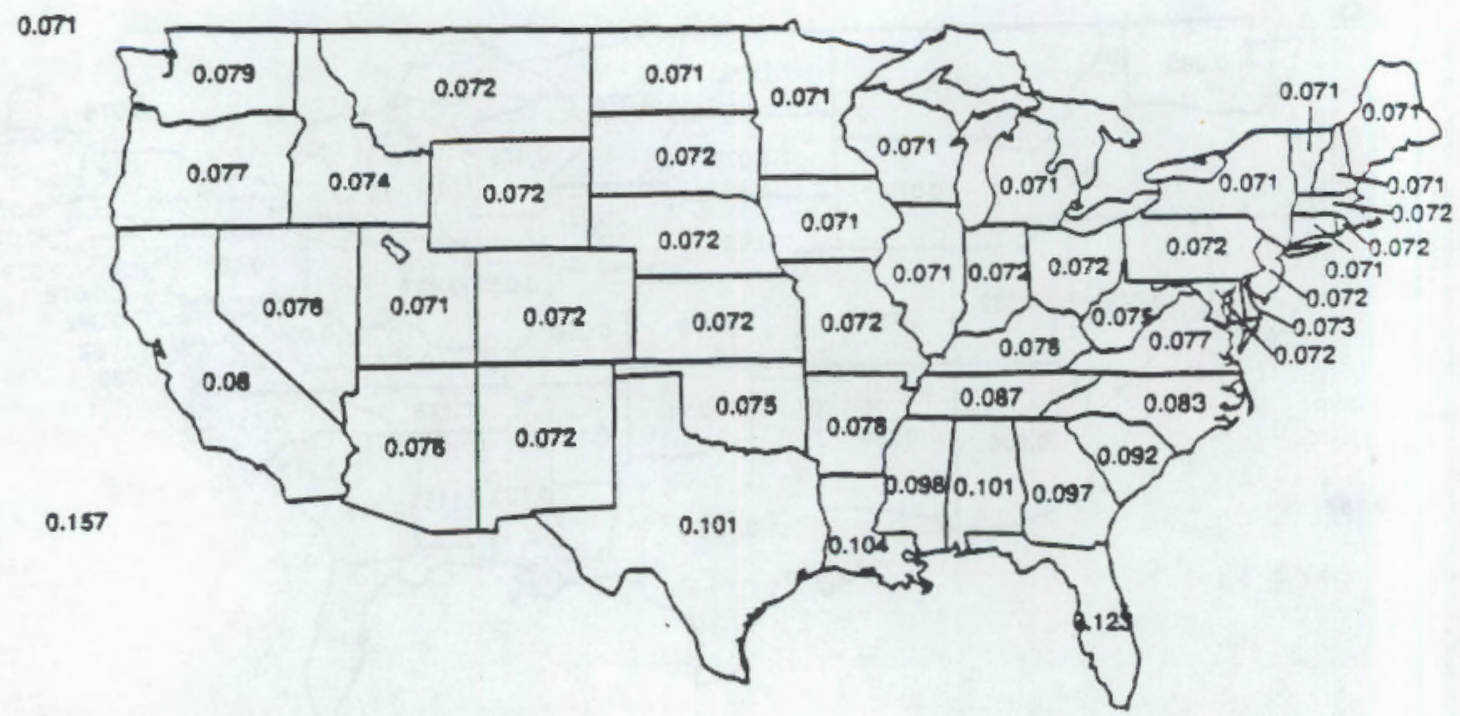

FIGURE D.4. Optimum Electric U-values by State 0.4 


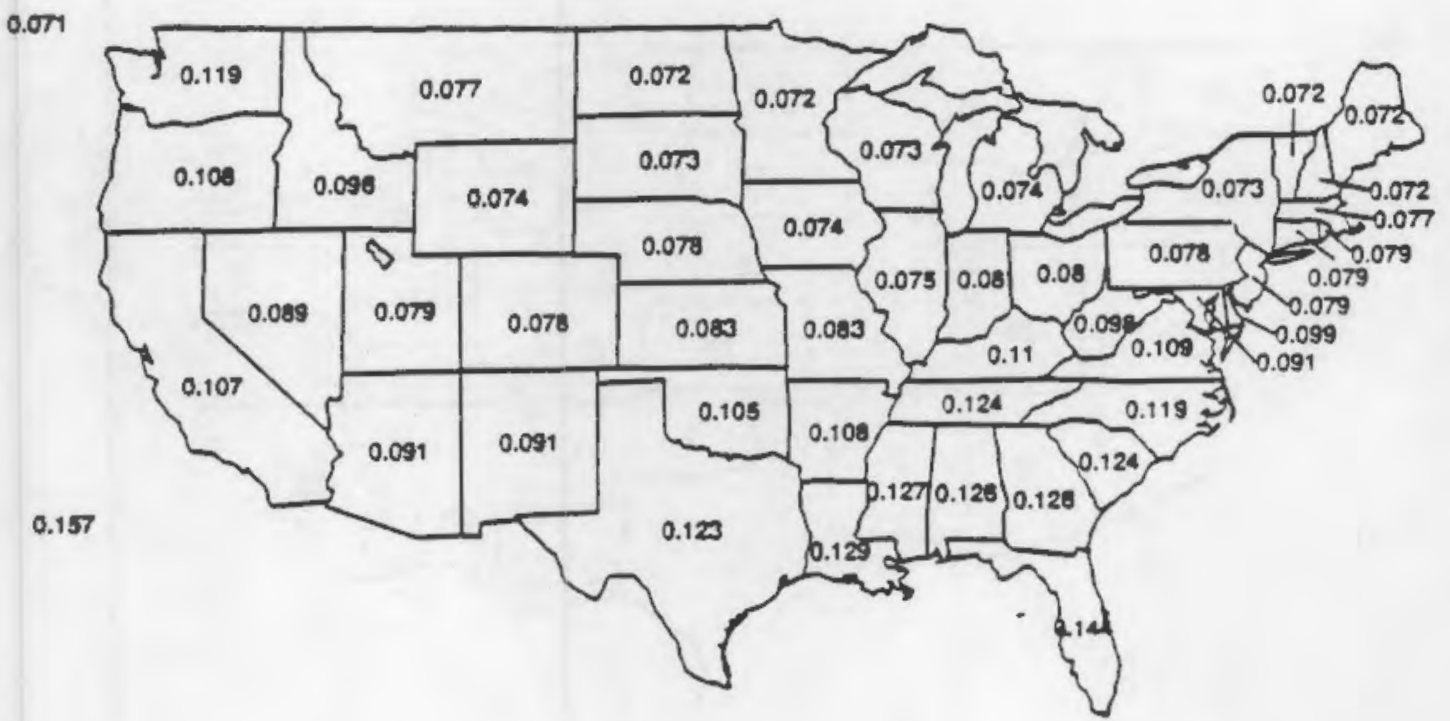

FIGURE D.5. Optimum Heat Pump U-values by State

To help visualize the results of the optimization, the average optimum component R-values produced in each state are shown in the next four figures, Figures D.6 through D.9. For the ceiling, wall, and floor the value for each state is the average R-value for the component insulation. Note that the average of several common R-values may be an R-value that is never actually used. For instance, the average of a group, most of which is R-13 wall insulation with some R-19 wall insulation, could be R-15. For the window figure, D.9, a single-pane window was given a value of 1 , a single-pane window with storm was given a value of 2 , and a double-pane vinyl window was given a value of 3 . These were the only three windows selected by the optimization.

These figures are simply for illustration because R-values are more intuitively grasped by most people than U-values. Since building components may vary in relative size, buildings actually built with these R-values would not necessarily meet the HUD U-value standard proposed herein. 


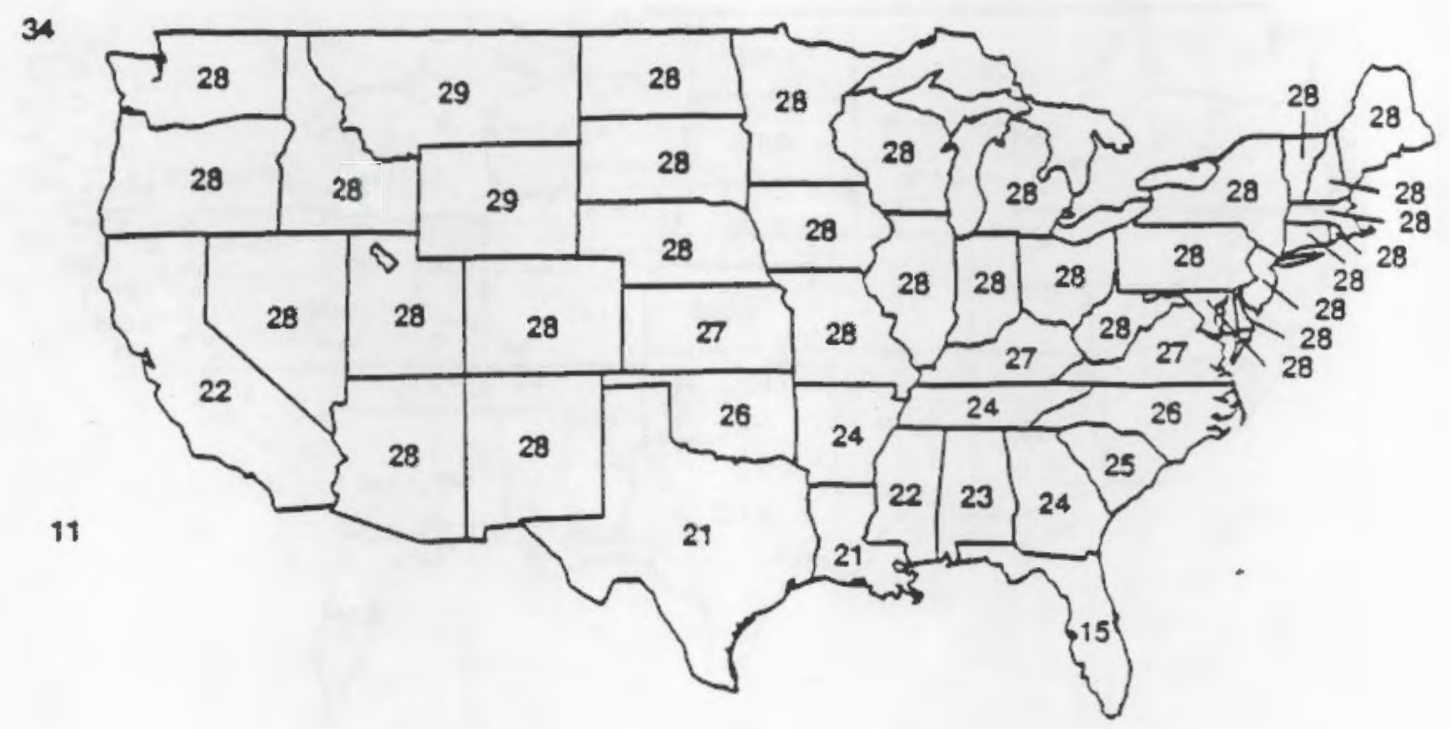

FIGURE 0.6 . Average Ceiling R-value by State

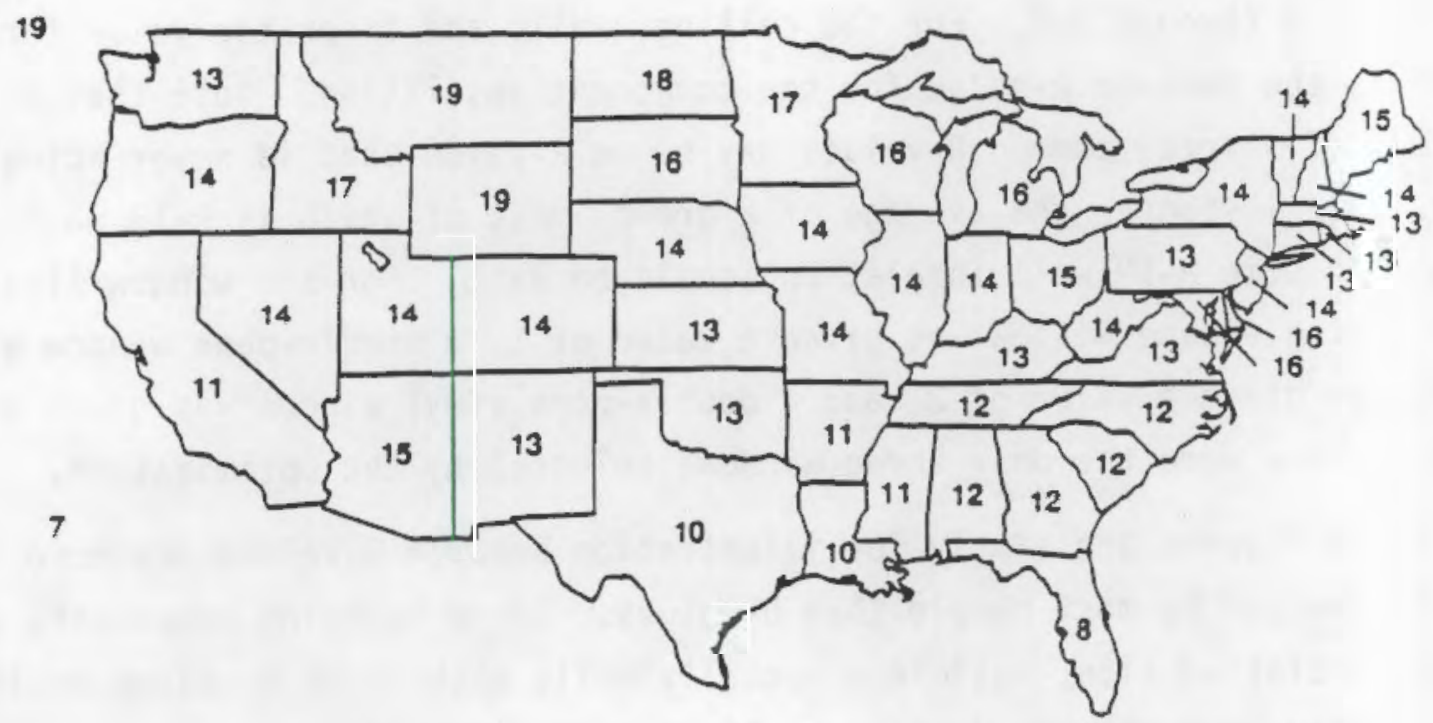

FIGURE 0.7 . Average Wall R-value by State

D.6 


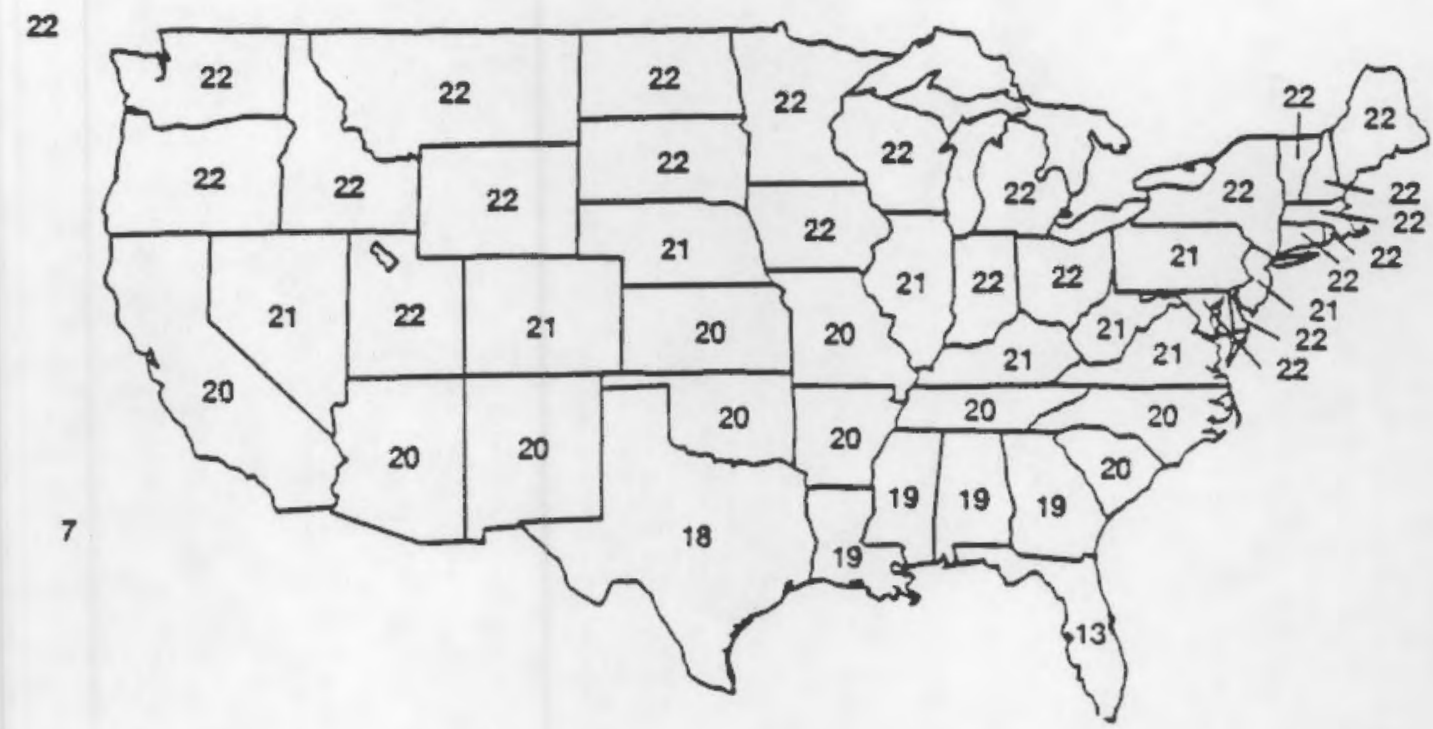

FIGURE 0.8 . Average Floor R-value by State

3

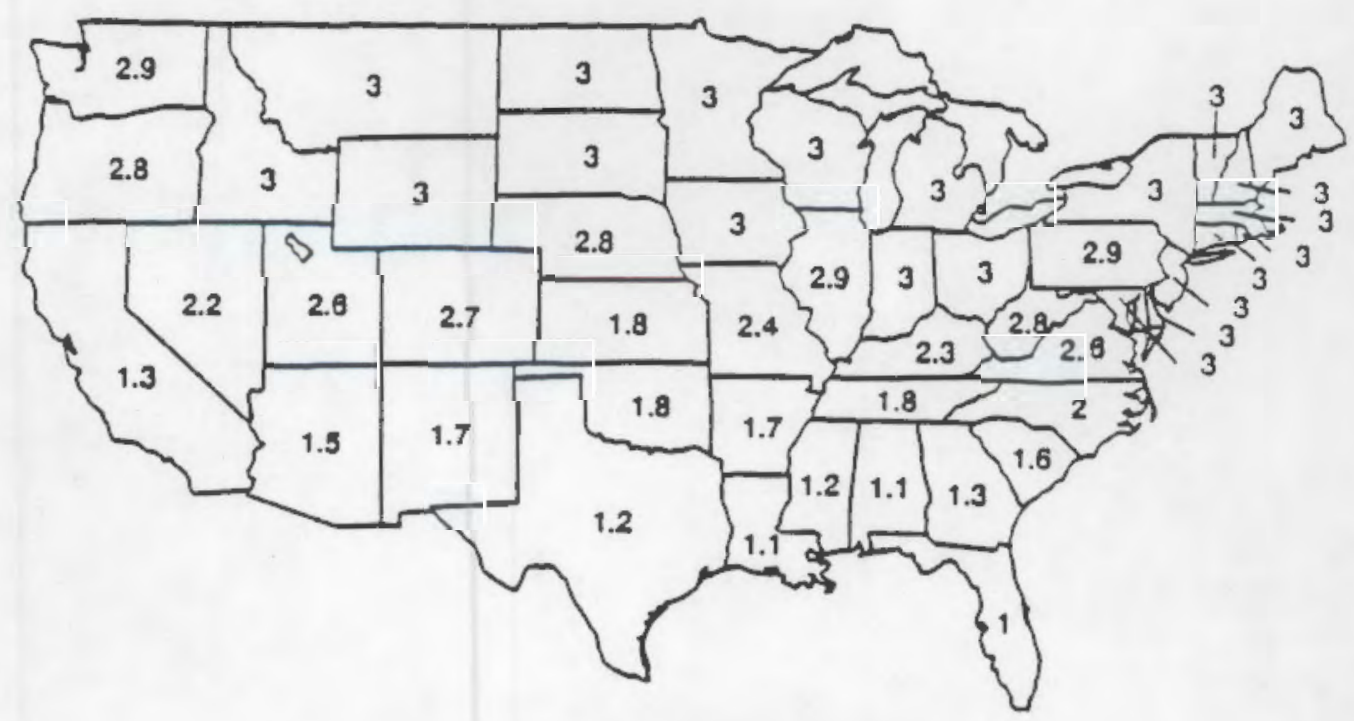

FIGURE 0.9 . Average Window by State

D.7 


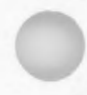

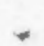

-

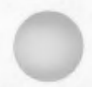

• 


\section{APPENDIX E}

HOME SHIPMENTS BY STATE, 1984 THROUGH 1988 
APPENDIX E

HOME SHIPMENTS BY STATE, 1984 THROUGH 1988

TABLE E.1. Mean Home Shipments by State, 1984 Through 1988 (a)

State

Alabama

Alaska

Arizona

Arkansas

California

Colorado

Connecticut

Oelaware

Washington D.C.

Florida

Georgia

Hawa $i$

Idaho

Illinois

Indiana

Iowa

Kansas

Kentucky

Louisiana

Maine

Maryland

Massachusetts

Michigan

Minnesota

Mississippi

Missouri
Shipments

11,268

95

5,715

4,912

10,230

1,093

350

2,106

0

27,632

16,784

1

992

3,331

6,009

882

1,769

5,359

5,658

2,158

1,304

821

8,849

1,700

5,509

4,987

(a) Summarized from reports by the Mobile/Manufactured Home Merchandiser, Chicago Illinois. Based on the April issues for 1985 through 1989, which contain the annual shipments by state.

$$
\text { E.1 }
$$


TABLE E.1. Mean Home Shipments by State, 1984 to 1988 (contd)

\begin{tabular}{lrr} 
State & Shipments \\
\cline { 1 - 1 } Montana & 759 \\
Nebraska & & 561 \\
Nevada & 1,737 \\
New Hamphire & & 1460 \\
New Jersey & & 802 \\
New Mexico & & 3,497 \\
New York & & 7,436 \\
North Carolina & & 23,482 \\
North Dakota & & 359 \\
Ohio & 6,354 \\
Oklahoma & & 2,764 \\
Oregon & 2,862 \\
Pennsylvania & 6,977 \\
Rhode Island & 163 \\
South Carolina & 13,156 \\
South Dakota & 652 \\
Tennessee & 8,248 \\
Texas & 18,063 \\
Utah & 661 \\
Vermont & 731 \\
Virginia & 6,098 \\
Washington & 4,844 \\
West Virginia & 3,103 \\
Wisconsin & 2,197 \\
Wyoming & 339 \\
U.S. Total & 246,820
\end{tabular}

Figure E.1 shows presents the data in the table above graphically. In this graphic the radius of the circle centered in a state is proportional to the sales in that state. 


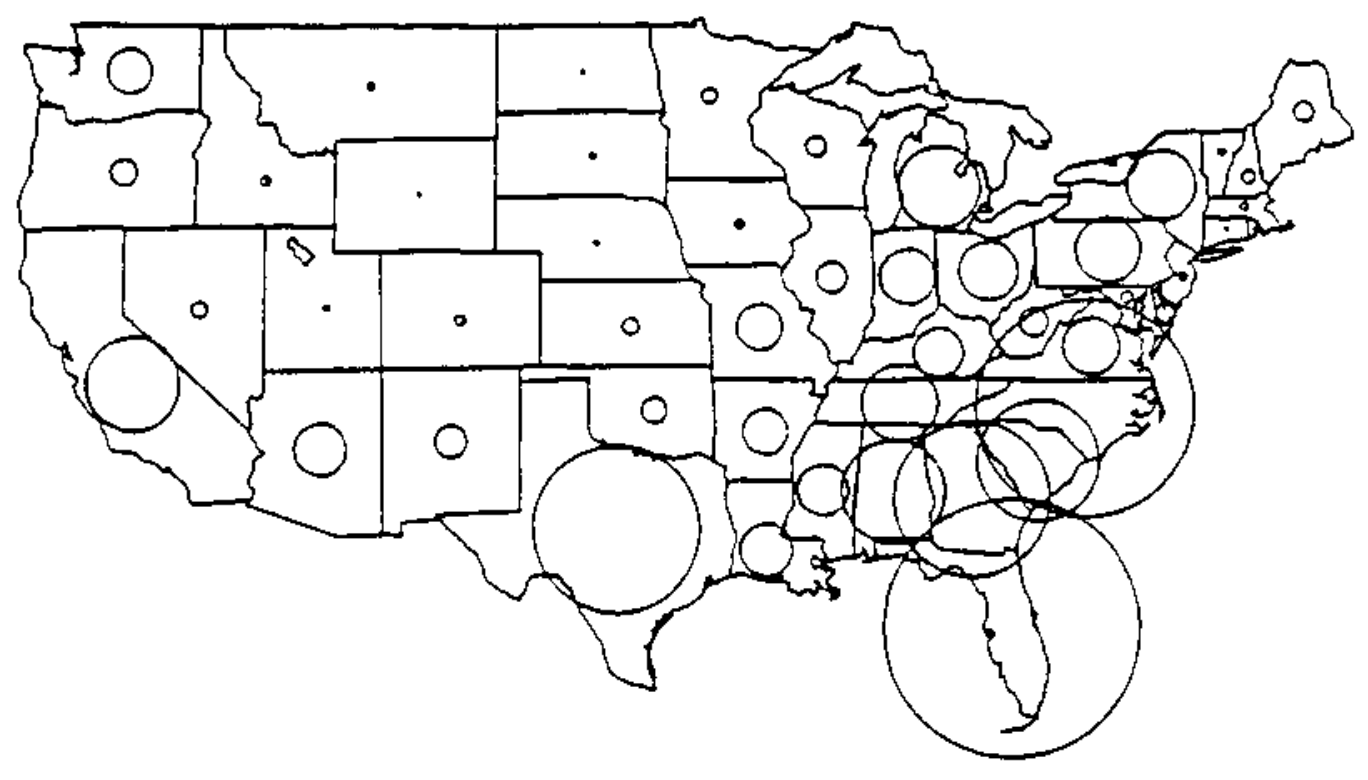

FIGURE E.1. Home Shipments by State 
APPENDIX $F$

HIGH-EFFICIENCY HVAC EQUIPMENT ADJUSTMENT 


\section{APPENDIX F}

\section{HIGH-EFFICIENCY HVAC EQUIPMENT ADJUSTMENT}

This appendix describes the development of the equation that al lows the trade-off of higher-efficiency HVAC equipment for higher home U-value such that the home energy use remains equal to the energy requirements implicit in the standard and thereby meets the revised HUD standard. This alternative allows the consumer or manufacturer the choice of investing in higherefficiency HVAC equipment as an alternative to lower U-values.

The goal of the equation developed here is to modify the required U-value by a factor that accounts for the energy savings resulting from increased heating and/or cooling efficiency. The factor will be greater than 1.0 so that the adjusted U-value requirement is higher than the standard U-value requirement. This effectively reduces the amount of insulation required when HVAC efficiency is increased above the standard level.

The approach is to equate the energy consumption of a home built to the standard $U$-value and efficiency requirements with the energy consumption of a home built with a higher U-value but higher HVAC efficiency:

$$
E_{s t d}=E_{a d j}
$$
where $\quad E_{\text {std }}=\begin{aligned} & \text { energy consumption of a house built to the standard } \\ & \text { U-value and HVAC efficiency requirements }\end{aligned}$

$$
E_{a d j}=\begin{aligned}
& \text { energy consumption of a house built to a higher U-value } \\
& \text { requirement but having higher HVAC efficiencies. }
\end{aligned}
$$

To derive the adjusted $U$-value requirement, a simple means of estimating energy consumption as a function of U-value and HVAC efficiencies is needed. The variable base degree day (VBDD) method, as described in the 1989 ASHRAE Handbook of Fundamentals (ASHRAE 1989), was selected for this purpose. The VBDD method may be expressed as follows (a):

(a) 1989 ASHRAE Handbook of Fundamentals, Chapter 28, equations 5 and 22. 


$$
\begin{aligned}
& E_{h}=\frac{(24)^{\star}(U A)^{\star}(H D D)}{e_{h}} \\
& E_{c}=\frac{(24)^{\star}(U A)^{\star}(C D D)(1+\alpha)}{e_{c}}+E_{C C}
\end{aligned}
$$

$$
\text { where } \quad \begin{aligned}
& E_{h}=\text { heating energy }(\mathrm{Btu} / \mathrm{h}) \\
& E_{c}=\text { cooling energy }(\mathrm{Btu} / \mathrm{h}) \\
& U A=\text { overall thermal transmittance }\left(\mathrm{Btu} / \mathrm{h} /{ }^{\circ} \mathrm{F}\right) \\
& H D D=\text { annual heating degree-days }\left({ }^{\circ} \mathrm{F}\right) \\
& C D D=\text { annual cooling degree-days }(\mathrm{a})\left({ }^{\circ} \mathrm{F}\right) \\
& e_{h}=\text { average efficiency of heating equipment } \\
& e_{c}=\text { average efficiency of cooling equipment } \\
& { }_{\mathrm{E}}=\text { energy consumed by crankcase heater }(\mathrm{Btu} / \mathrm{h}) \\
& { }_{a}=\text { duct loss factor. }
\end{aligned}
$$

To adjust the required UA (and hence $U_{0}$ ) to account for changes in heating and/or cooling efficiency, total energy consumption is forced to be equal in both cases. That is, the following equality is enforced:

$$
E_{h, \text { adj }}+E_{c, \text { adj }}=E_{h, s t d}+E_{c, s t d}
$$

The " $h$ " and "c" subscripts refer to heating and cooling, respectively, while the "std" and "adj" subscripts refer to standard and adjusted houses. Expressing Equation F.3 in terms of the VBDD calculations of Equation F.2 gives the following(b):

(a) These must be adjusted to account for latent loads and ventilation as described on page 28.7 in Equations 21, 26, and 27 of the 1989 ASHRAE Handbook of Fundamentals.

(b) Note that the crankcase heater occurs on both side of the equation and; therefore, is subtracted out from both sides of the equation. The duct losses are included in ASHRAE's cooling equation but not in the heating equation. For this equation, the duct losses are assumed to be the same for both the heating and cooling equations, and therefore cancel out. 


$$
\begin{aligned}
& {\left[\frac{(24)\left(U A_{s t d}\right)\left(H D D_{s t d}\right)}{e_{h, s t d}}\right]+\left[\frac{(24)\left(U A_{s t d}\right)\left(C D D_{s t d}\right)}{e_{c, s t d}}\right]=} \\
& {\left[\frac{(24)\left(U A_{a d j}\right)\left(H O D_{a d j}\right)}{e_{h, a d j}}\right]+\left[\frac{(24)\left(U A_{a d j}\right)\left(C D D_{a d j}\right)}{e_{c, a d j}}\right]}
\end{aligned}
$$

Variable based degree days are determined based on the temperature at which the building needs to begin heating or cooling, which is often called the "balance temperature". When the UA changes, the balance temperature changes, modifying the number of degree days.(a) Accounting for this change is complicated because the outdoor temperature patterns vary widely from location to location. Therefore, a sample of 42 cities that cover the range of climates in the continental U.S. was selected for detailed analysis. (b) (c)

Generally, the change in degree days associated with a change in the balance temperature driven by a change in the U-value is a complicated function of local climate patterns. The range of HVAC efficiency options is limited to those above the National Appliance Energy Conservation Act of 1987 (NAECA) (Public Law 100-12, March 17, 1987) minimums. The U-values considered start with the U-values in the standard and, therefore, do not include very low Uvalues. Given this limited range, our analys is showed that the change in

(a) Equations 3 and 20 of Chapter 28, 1989 ASHRAE Handbook of Fundamentals.

(b) The cities were selected by (Huang et al. 1987) to represent the variation in climate in the U.S. All cities for which degree day data was available in 01 sen et al. (1984) were used. Based on the 1989 ASHRAE Handbook of Fundamentals's recommendation, WYEC (Weather Year for Energy Calculation) was used if available, otherwise TRY (Typical Reference Year) weather data was used. Because only two cites were included in zone 1 (Florida), data for Tampa, Florida was also included.

(c) The cites were: Jacksonville $\mathrm{FL}$, Miami FL, Tampa FL, Atlanta GA, Birmingham AL, Brownsville TX, Charleston SC, EI Paso TX, Fort Worth TX, Lake Charles LA, San Antonio TX, Albuquerque NM, Fresno CA, Kansas City MO, Los Angeles CA, Memphis TN, Nashville TN, Oklahoma City OK, Phoenix AZ, San Oiego CA, San Francisco CA, Bismarck ND, Boise ID, Boston MA, Buffalo NY, Burlington VT, Cheyenne WY, Chicago IL, Cincinnati OH, Great Falls MT, Las Vegas NV, Medford OR, Minneapol is MN, New York NY, Omaha NB, Philadelphia PA, Pittsburgh PA, Portland ME, Portland OR, Salt Lake City UT, Seattle WA, and Washington $D C$. 
degree days is approximately proportional to the change in U-value. That is, the heating degree days can be calculated as follows:

$$
\begin{aligned}
H D D_{a d j}-H D D_{s t d} & =M_{h} *\left(U A_{a d j}-U A_{s t d}\right) \\
& - \text { or }- \\
H D D_{a d j} & =H D D_{s t d}+M_{h} *\left(U A_{a d j}-U A_{s t d}\right)
\end{aligned}
$$

The slope of the relationship between degree days and U-value, $M_{h}$, was derived empirically for each of the 42 analyzed cities. To obtain typical UA values, a typical home was analyzed in each location. The UA was increased $20 \%$ from the standard level and the corresponding change in degree days calcu-

\begin{tabular}{|c|c|c|c|c|}
\hline & Zone 1 & Zone 2 & Zone 3 & Zone 4 \\
\hline Standard UA (Btu/hr $\left.{ }^{\circ} \mathrm{F}\right)$ & 459 & 379 & 334 & 275 \\
\hline Adjusted UA (Btu/hr $\left.{ }^{\circ} \mathrm{F}\right)(\mathrm{b})$ & 551 & 455 & 401 & 330 \\
\hline \multicolumn{5}{|l|}{ Internal gains (Btu/hr)(c) } \\
\hline Heating & 3000 & 3000 & 3000 & 3000 \\
\hline Cooling & 4500 & 4500 & 3000 & 3000 \\
\hline \multicolumn{5}{|l|}{ Thermostat setting (F) } \\
\hline Heating & 70 & 70 & 70 & 70 \\
\hline Cooling & 78 & 78 & 78 & 78 \\
\hline Volume $\left(\mathrm{ft}^{3}\right)$ & 9000 & 9000 & 9000 & 9000 \\
\hline \multicolumn{5}{|l|}{ Indoor humidity ratio (d) } \\
\hline$\left(1 b_{\mathrm{H} 20} / 1 b_{d a}\right)$ & 0.011 & 0.011 & 0.011 & 0.011 \\
\hline \multicolumn{5}{|l|}{ Ventilation rate when vented } \\
\hline cooling possible $(A C H)(e)$ & 5.0 & 5.0 & 5.0 & 5.0 \\
\hline
\end{tabular}
lated(a) The assumed characteristics of the example home are shown in Table F.1.

Table F.1. Assumptions for Derivation of UA/OD Relationship

(a) As noted previously, the degree day data were taken from 0lsen et al. (1984).

(b) These are the standard UAs above, plus $20 \%$.

(c) From the 1989 ASHRAE Handbook of Fundamentals. The internal gains are discussed on pages 28.4 and 28.5. The latent load adjustment is based on Equation 21 on page 28.7. The latent loads in zones 3 and 4 were 0 by this equation.

(d) Based on the value used as typical in the 1989 ASHRAE Handbook of Fundamentals, Equation 21 on page 28.7

(e) Based on example 2, page 28.7 of the 1989 ASHRAE Handbook of Fundamentals. 
Substituting Equation F.5b (and a similar relationship for cooling degree days) into Equation F.4 and simplifying gives the following:

$$
\begin{aligned}
& {\left[\frac{M_{h}}{e_{h, a d j}}+\frac{M_{c}}{e_{c, a d j}}\right] *\left(U A_{a d j}\right)^{2}} \\
& +\left[\frac{\left.\frac{H D D_{s t d}-\left(M_{h}\right)\left(U A_{s t d}\right)}{e_{h, a d j}}+\frac{C D D_{s t d}-\left(M_{C}\right)\left(U A_{s t d}\right)}{e_{C, a d j}}\right] *\left(U A_{a d j}\right)}{e_{h, s t d}}\right]=0
\end{aligned}
$$

Equation F.6 is a quadratic that can be solved for the adjusted UA that holds consumption constant when the heating and cooling efficiencies are adjusted. For each of the 42 cities, Equation F.6 was applied for a range of possible combinations of heating and cooling efficiencies. The adjusted UAs calculated by this method were divided by the base (standard) UAs to obtain simple $U_{0}$ adjustment factors. Table F.2 is an example of the type of matrix that was formed for each city. This table is shown only to illustrate the method that produced the general adjustments.

Notice that at the NAECA minimum efficiency levels, the UA adjustment factor is unity. As either heating or cooling efficiency increases, the $U_{0}$ adjustment factor increases, implying that the $\mathrm{U}$-value allowed under the standard increases. In this table, for example, the $\mathrm{U}_{0}$ may be 13\% higher than the standard requirement if the cooling SEER is increased to 10.0 and the heating AFUE is increased to 0.90 . 
TABLE F.2. U Adjustments That Hold Energy Use Constant for Sample City Cooling SEER

\begin{tabular}{|c|c|c|c|c|c|c|c|}
\hline & 9.7 & 10.0 & 10.5 & 11.0 & 11.5 & 12.0 & 12.5 \\
\hline EUE 0.75 & 1.000 & 1.007 & 1.018 & 1.027 & 1.036 & 1.045 & 1.052 \\
\hline AFUE 0.80 & 1.041 & 1.049 & 1.060 & 1.071 & 1.080 & 1.089 & 1.097 \\
\hline AFUE 0.85 & 1.082 & 1.090 & 1.102 & 1.1 & 1.123 & 1.1 & 1.141 \\
\hline AFUE 0.90 & 1.122 & 1.130 & 1.143 & 1.155 & 1.166 & 1.175 & 1.184 \\
\hline AFUE 0.95 & 1.162 & 1.171 & 1.184 & 1.196 & 1.208 & 1.218 & 1.227 \\
\hline FUE 1.00 & 1.201 & 1.211 & 1.225 & 1.238 & 1.249 & 1.260 & 1.270 \\
\hline
\end{tabular}

Each matrix of $U_{0}$ adjustment factors (one for each city) was then subjected to a linear regression analysis to encode the data in a simple equation. The form of the regression equation was as follows:

$$
\begin{aligned}
\frac{U_{0, a d j}}{U_{0, s t d}}=1.0 & +a *\left[\left(\text { AFUE }_{a d j}-\text { AFUE }_{\text {std }}\right) / \text { AFUE }_{\text {std }}\right] \\
& +\beta *\left[\left(\text { SEER }_{\text {adj }}-\text { SEER }_{\text {std }}\right) / \text { SEER }_{\text {std }}\right]
\end{aligned}
$$

In this equation, the heating and cooling terms are independent, although in theory, the two are interrelated. For example, if the heating efficiency is increased, the U-value can be increased to compensate the reduced heating load. However, this might have an adverse effect on cooling, meaning the actual $U_{0}$ adjustment should be smaller than would be indicated by examining heating loads alone. In reality, over this limited range of efficiency values and $\mathrm{U}$-values, the interrelationships are weak and the error of linearizing the equation is small, justifying the reduction in complexity.

The coefficients $\alpha$ and $\beta$ obtained from all cities were averaged within climate zones to obtain zonal adjustment factors. The variation of the zone means for the heating factor was less than $10 \%$ without a clear pattern within zones; therefore, the average factor of 0.60 was used. The cooling factors varied widely and are shown in Table F.3 below. 
TABLE F.3. U Adjustment Coefficients for Cooling

\begin{tabular}{|c|c|}
\hline Zone & $\beta$ \\
\hline 1 & $0.60(a)$ \\
\hline 2 & 0.20 \\
\hline 3 & 0.07 \\
\hline 4 & 0.03 \\
\hline
\end{tabular}

The calculation of an adjusted U-value based on the use of the high efficiency HVAC equipment is illustrated below, based on equation F.8. This example assumes a high-efficiency gas furnace with an AFUE of 85, rather than the standard AFUE of 75, is installed in zone 3. A high efficiency air-conditioner with an SEER of 11 is assumed in the home. Note, the $U_{0}$ for zone 3 is 0.096 . Using Equation F.8, the adjusted U-value for this home is calculated as follows:

$$
\begin{aligned}
\frac{U_{0, a d j}}{U_{0, \text { std }}=1.0}+0.60 *\left[\left(\text { AFUE }_{\text {adj }}-\text { AFUE }_{\text {std }}\right) / \text { AFUE }_{\text {std }}\right] \\
+\beta *\left[\left(\text { SEER }_{\text {adj }}-\text { SEER }_{\text {std }}\right) / \text { SEER }_{\text {std }}\right] \\
U_{a d j}=0.096 *\left[1+0.60 * \frac{85-75 \text { AFUE }}{75 \text { AFUE }}+0.20 * \frac{11-9.7 \text { SEER }}{9.7 \text { SEER }}\right]
\end{aligned}
$$

Therefore, the adjusted $U$-value required for the home is:

$$
U_{\text {adj }}=0.096 \times(1+(0.60 \times 0.133)+(0.20 \times 0.134))=0.106
$$

The adjusted U-value of 0.106 would be the U-value for the home with the high efficiency HVAC required to comply with the standard.

For the standard, equation $F .8$ is revised to simplify its application as:

(a) The cooling factors for cities in Florida varied widely. 0.60 was selected and intermediate between the mean and median. The ASHRAE assumptions used here lead to the conclusion that more credit might be obtained for high efficiency HVAC equipment for cities in the Miami area if the calculation/simulation alternative suggested in Section 6 was used. 


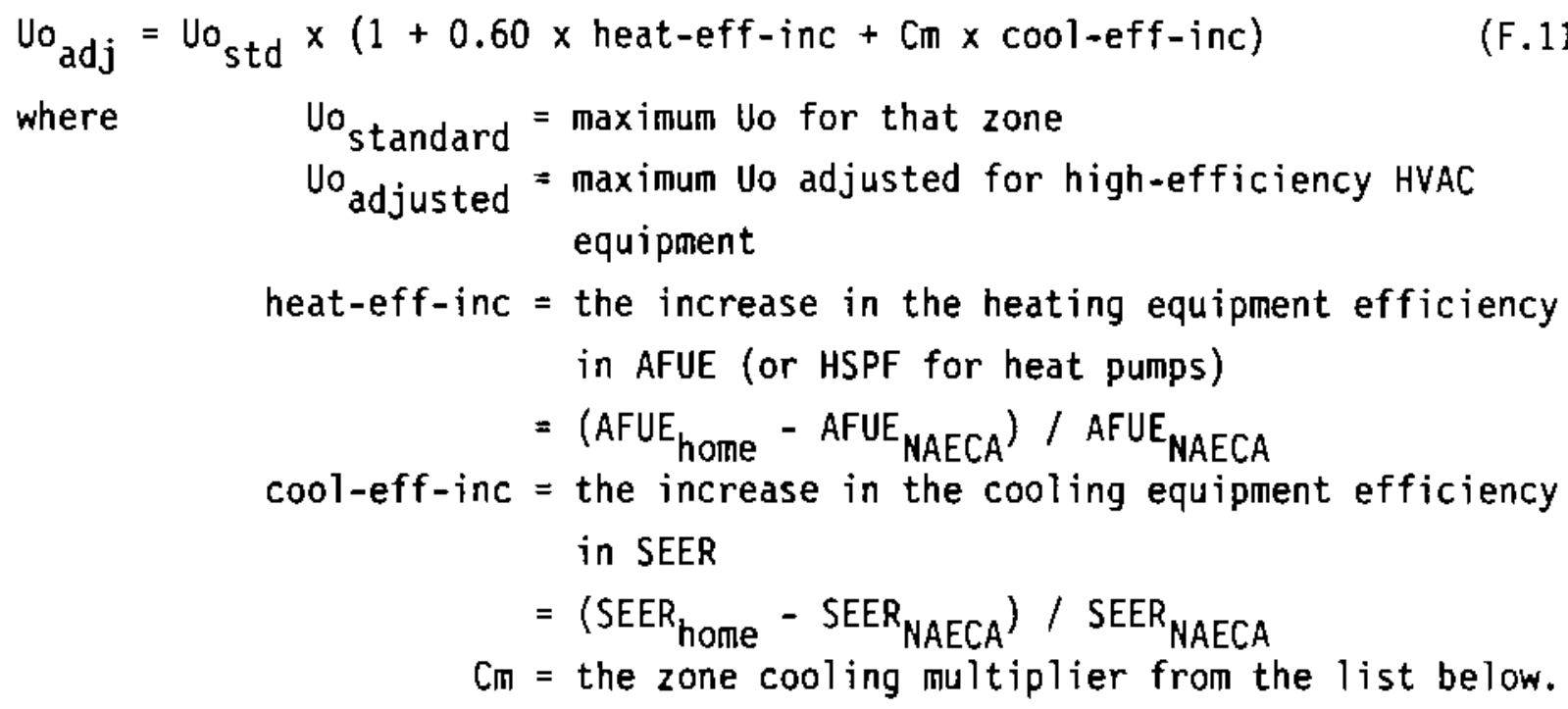

$\begin{array}{ccc}\text { Zone } & & \text { Cooling Multiplier } \\ 1 & & 0.60 \\ 2 & 0.20 \\ 3 & 0.07 \\ 4 & 0.03\end{array}$




\section{REFERENCES}

American Society of Heating, Refrigerating, and Air-Conditioning Engineers, Inc. (ASHRAE). 1989. ASHRAE Handbook 1989 Fundamentals. Atlanta, Georgia.

Huang, Y. J., et al. 1987. Methodology and Assumptions for Evaluating Heating and Cooling Energy Requirements in New Single Family Residential Buildings. Technical Support Document for the PEAR Microcomputer Program, LBL-19128, Lawrence Berkeley Laboratory, Berkeley, California.

National Appliance Energy Conservation Act of 1987 (NAECA), Public Law 10012. March 17, 1987.

0lsen, A. R., S. Moreno, J. Deringer, C. R. Watson. 1984. Weather Data for Simplified Energy Calculation Methods. PNL-5143, Volumes I-IV, Pacific Northwest Laboratory, Richland, Washington. 


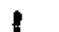


APPENDIX G

FAILURES IN THE MARKET FOR ENERGY EFFICIENCY 


\section{APPENDIX G}

\section{FAILURES IN THE MARKET FOR ENERGY EFFICIENCY}

The basis for HUD's action to revise the MHCSS thermal requirements is provided by Congress (HCDA 1987; CRH 1987; CRS 1987). From a social or national perspective, additional support for this revision of the thermal standards is provided by the argument that the market is not correctly valuing energy efficiency options in manufactured homes. Two market failures related to manufactured home energy efficiency are explored in this appendix. The value of the impact of energy use on the environment, which is external to the market, is explored in Appendix $H$.

Following the discussion of the market failures, there is a discussion of the levels of manufactured-home energy efficiency produced by the market before HUD regulated the thermal construction of the homes. The low levels of energy efficiency produced by the pre-regulation market and the resultant major increase in the life-cycle costs to the consumer provide justification for HUD's thermal regulation.

Alternatives to this revision of the MHCSS are explored briefly at the end of this appendix. Because these alternatives do not comply with the statutory requirements (HCDA 1987; CRH 1987; CRS 1987), they were not explored in detail.

\section{NATURE OF THE MARKET FAILURES}

There are three major areas where the market for manufactured-home energy efficiency fails: 1) the consumer's inability to monitor and evaluate energy efficiency prior to purchase, 2) the imperfect pricing of energy, and 3) the market externalities, especially the environmental externalities. The first two will be dealt with in this appendix. The environmental externalities will be dealt with in Appendix $H$.

Consumers Inability to Evaluate Energy Options

Financially the consumer would like to select a home with a level of energy efficiency near the optimum level of cost-effectiveness, effectively 
making an investment in energy efficiency. The consumer has several difficulties in making a credible estimate of the Tife-cycle costs offered by the competing energy-efficiency options prior to purchase. The initial difficultly is in determining and verifying the energy-related features of the home. For the most part, the elements of a home that determine energy efficiency are hidden; for example, the consumer cannot see the insulation or the method of construction used in the home's structure. The only energy feature in the building's shell that is generally easily observed and verified is the number of panes in a window, a single-pane window can be distinguished from a double pane-window. (a)

Selecting from the energy-efficiency options available in manufactured homes requires that the consumer be able to reasonably estimate the energy consumption of the options prior to purchase. The energy consumption of a home is a complex function of several parameters and is difficult for the average consumer to evaluate. The major parameters that affect the energy use of a home include the climate in which the home is to be placed, the insulation level and window conduction, the construction methods used on the home's shell, the heating and cooling system efficiencies, the current and future price of energy, and the behavior of the occupants of the home. Furthermore, many of the interactions are nonlinear and not intuitive; for example, installing twice as much insulation in a home does not save twice as much energy. (b)

Being unable to effectively differentiate between the alternatives, the consumer will often buy the option with the lowest first cost. The manufacturers have little incentive to include energy efficiency above the level that the consumer can observe and value. Therefore, the market drives the builders of manufactured homes to produce homes with low first costs and very suboptimum levels of energy efficiency.

(a) Even in windows, the overall thermal transmission of the window is very difficult to gauge because other factors that may not be visible, like frame construction and the use of argon or other gases, strongly impact thermal transmission.

(b) Energy use varies approximately with the inverse of the level of insulation, which is counter intuitive to many people. For this reason, the marginal value of increments of insulation sharply decreases with increasing insulation level. 
From the consumer's perspective the existence of an energy code greatly simplifies their investment in energy efficiency. Homes that comply with the code have a minimum level of energy efficiency built into the home, a level that is set based on an analysis of what is cost-effective from the (general) consumers' perspective. With an energy efficiency standard in place, most consumers need only to know that their home complies with the code. The consumers who want to invest in additional energy efficiency can still choose products that exceed the minimum requirements.

\section{Imperfect Energy Price Signals in the Market}

Residential consumers get imperfect price signals for electricity and natural gas. The price setting mechanisms and marginal costs for energy are unusual in many respects. Energy is a product of a "natural monopoly", the utilities. The energy price structure is primarily regulated by Public Utility Commissions (PUCS) rather than by market transactions. The PUCs generally require the residential consumers be charged average prices reflecting the average cost for the utility to supply the energy instead of full marginal prices. PUC decisions are strongly influenced by the political process and do not necessarity reflect the market directly. The average price for natural gas and electricity usually does not reflect either 1) the marginal cost to the utilities to expand to provide energy to new users or 2) the higher capacity costs associated with heating and cooling loads. Each of these market failures is discussed below.

Residential HVAC Capacity Costs Not Reflected in Market Price

One cost of providing electricity or natural gas is the cost of building the "capacity" to provide the energy. Capacity costs are the costs of the equipment that generates the electricity or the pipeline that supplies the natural gas. Capacity is differentiated from the cost of the fuel; for example, differentiating between the cost of the coal burned at a coal-fired electric plant and the cost of the electric plant itself.

The cost of the capacity per unit energy delivered is dependant on the type of load being served. "Base loads" are loads that are more or less constant so that the cost of the facility serving these loads can be amortized over a large base resulting in low capacity costs per unit of energy. At the 
other extreme, "peak loads" are loads that occur predominately at times of the greatest power demand. Peak loads require the utility to invest in facilities that are used infrequently and must remain idle most of the time. HVAC loads are particularly nonuniform and contribute disproportionately to the requirements for peak capacity. (a) The average cost to a utility for delivering base load energy is sometimes much less than the cost of delivering peak load energy.

HUD's revised standard for building shell thermal integrity will affect the heating and cooling energy used by manufactured homes. Because heating and cooling loads tend to occur during peak demand periods, they strongly affect capacity costs. In climates where heating dominates, utilities peak in the winter and heating is a disproportionate contributor to the winter peaks and the system peaks. In climates where cooling dominates, the utilities peak in the summer and the cooling loads are a disproportionate contributor to the utilities' summer peak and system peaks.

A demand charge, which prices energy based on "time-of-day" or "time-ofyear", is often used to raise the cost of energy during the time of peak demand, when it costs the utility more to deliver the energy. Therefore, demand charges help send the correct price signal. Demand charges are usualiy used for the commercial or industrial customers. For various reasons, including the cost of metering and collecting the data, demand charges are not usually applied to residences. Residential consumers usually pay average costs. Because there is seldom a demand charge for residential customers, the higher cost of heating and cooling loads is not reflected in the price paid by the residential customers.

The utility is not able to refuse to sell at a loss (above-average cost power sold at average cost) during peaks times; rather, it must attempt to meet all the instantaneous demands for energy in its service territory. Therefore, the utility's capital expenditures to expand inefficientiy-utilized peak

(a) Other types of loads have more favorable effects on the utilities capacity costs. For example, refrigerators have a relatively constant load that does not change greatly with the time-of-day or time-of-year. Energy used by the refrigerator tends to contribute to a utility's base load. 
capacity are not an endogenous decision, but are imposed by a market that sees only an average price.

\section{Marginal Costs Usually Higher than Average Costs}

For most utilities in growth areas, especially utilities in regions where most new manufactured homes are being placed, the cost of generating new power is higher than the cost of generating power from the existing capacity. (a) For example, in the Pacific Northwest, the cost of new electric power is on the order of twice the cost of existing power(b) in part because new power may be coal or nuclear, while much of the existing power is hydroelectric.

The difference in the cost of supplying power with new facilities and supplying power with old facilities is so large for some utilities that the utilities encourage customers to use less energy, which is called "demand side management" (DSM) by the utilities. The DSM programs promote using energy more efficiently rather than expanding utility capacity and generating more energy. Some utilities have strong interests in manufactured-home energy efficiency in particular because those homes contribute markedly to the growth of their loads. An example of this is the "Super Good Cents" consumer incentive program for conservation in the Pacific Northwest. This Bonneville Power Administration (BPA) program pays the buyer of a new manufactured home the entire cost to upgrade from the current HUD energy-efficiency standard to a BPA selected energy-efficiency goal, a payment of about $\$ 2,000$ per home. The regional energy planning agency in the Pacific Northwest has been active in trying to get HUD to adopt energy-efficiency requirements that are significantly more stringent than those currently proposed by HUD (Northwest Power Planning Council [NPPC] 1991).

(a) In some cases, 1) the ability to use the most economical fuels or sites has been saturated (for example, in the Pacific Northwest, the best sites to generate inexpensive hydro power are already in use); 2) the capital cost of new facilities is higher than the cost of old plants in use (the old plants may be paid for, or the new plants may incur environmental costs that were not present in old facilities): and/or 3 ) the utilities may face significant political opposition to new facilities (which can increase costs).

(b) Personal communication, Tom Ekman, Northwest Power Planning Council, September 1991. 
Unregulated Market Insulation Levels

Before 1976, HUD did not regulate the minimum thermal integrity in manufactured homes; therefore, this period can serve as a rough indicator of the level of energy efficiency investment that would be made without regulation. There are only a few sources of data for the level of insulation produced in this period; however, all indicate that the level of insulation was low. One source of information is an Energy Information Administration (EIA) publication (EIA 1989) that surveyed the characteristics of existing homes. (a) From the EIA data(b) it was estimated that at least $15 \%$ of the pre-regulation manufactured homes had no insulation in the walls, and that $20 \%$ had no insulation in the ceiling. (Floors were not specified, but the Hood River data below suggest a large percentage of unregulated homes may have no insulation in the floor.) Data from the Hood River Conservation Project for 94 homes built before 1970 also showed low levels of insulation for these Hood River Oregon homes. (c) Even with a wide variation in economic assumptions (e.g., discount rate, price escalation rate) homes with no insulation have significantly higher life-cycle costs than homes with optimum insulation levels in almost any part of the U.S.

Given the low levels of insulation, the energy used for heating and cooling of the homes with conservation levels cormon in the pre-regulation market would be very high, 2 or 3 times the energy use of the homes with the

(a) Page 20 of the EIA report gives the distribution of homes by year of construction. Pages 99 to 101 of the same report give overview information on insulation by component.

(b) Homes without insulation in a component were assumed to be built before the HUD thermal standards. This source does not give specific levels of insulation; the source notes on y if insulation was present or not.

(c) In order of occurrence, the three most common levels of insulation for each building component were: ceiling R-3, 11, and 7; walls R-3, 7, and 5; and floors R-3, 0, and 5. Given that this location is colder than the national average, this Hood River data supports the observation of low levels of insulation in pre-regulation homes. Using the most common combination of insulation R-values ( $R-3$ in all components) these homes would have had U-values of about 0.27 . The 0.27 is over twice the Uvalue of the current MHCSS thermal standard for Oregon (0.126) and over three times the value for Oregon in the proposed revision $(0.079)$. 
proposed standard revision.(a) In some pre-regulation homes, the energy bill for heating and cooling alone would have exceeded the mortgage payment during the peak of the heating/cooling seasons.

It is worth noting that the proposed revision results in a positive cash flow to the occupants very quickly, compared to the pre-regulation home. Assuming a down payment of $15 \%$; the proposed revision results in a net positive cash flow to most occupants some time in the second year when compared to the unregulated home, and some time in the third year when compared to the current regulation. Not counting the down payment, the positive cash flow from the proposed revision starts the first year in both cases.

Another piece of evidence that the investment in energy efficiency in the unregulated pre-1976 and current-regulation market is too low comes from the Department of Energy's Weatherization Program. This program invests significant funds in retrofiting manufactured homes to raise their energy efficiency (weatherization) to reduce energy use and decrease the residents' bills. (b) Currently, the National Weatherization Program spends about $\$ 40$ million per year on weatherizing manufactured homes. Although manufactured homes make up about $5 \%$ of the housing stock, they account for about $25 \%$ of the homes qualifying for low-income weatherization. The pre-1976 manufactured homes use about 1.25 to 2 times as much energy per square foot as comparable

(a) The ratio of the energy bills for different groups of homes can be estimated roughly from the ratio of their U-values. Most pre-regulation homes (pre-1976) probably ranged from about 0.35 (roughly no insulation) to perhaps 0.15 (roughly $R-11$ ceiling, $R-7$ walls, and $R-7$ floors). The average pre-regulation home's U-value probably fell between 0.2 and 0.3 . The proposed regulation requires a maximum U-value with a sales-weighted average of 0.098 for all U.S. homes. Therefore, the average U-values for the pre-regulation homes would be about 2 or 3 times that of the proposedrevision homes.

For comparison, the current-regulation homes would average about 0.145 nationally if all homes were built to the minimum requirements. Some homes are produced at much lower U-values, in particular some utilityfunded programs produce homes at about 0.07 . This report estimates the current national average $U$-value to be between about 0.125 and 0.140 .

(b) The decision to spend Federal money to improve homes is clearly political in part; however, it implies a problem with the energy efficiency of the old manufactured homes. 
site-built homes (Judkoff et a1. 1990). From a national perspective it is much more efficient to design and build homes with higher levels of energy efficiency than to modify the homes after they are built. For a given level of energy-efficiency, energy efficiency measures installed in the factory are more cost-effective than modifications to increase the efficiency of the home in the field.

\section{Alternatives to the Proposed Regulation}

Several alternatives HUD could undertake instead of the regulation proposed in this report are listed and discussed briefly below. The statutory requirements for the revision of the themal standard are relatively well specified (HCDA 1987; CRH 1987; CRS 1987). In addition to the problems listed below for each alternative, none of these alternatives would comply with the statutory requirements. Therefore, all were rejected after only a brief examination.

\section{Alternative: Propose an R-value Standard}

Instead of proposing a standard in terms of an overall $\mathrm{U}$-value of a home as is done here, HUD could specify to manufacturers how the home's exterior shell should be built.(a) Both the U-value and R-value specification would achieve the same level of energy use. However, the more performance-based $U$-value standard allows the builder a great deal of flexibility in how the home is built while achieving the overall energy-efficiency objective. Therefore, the U-value standard results in a more efficient, performance-oriented standard and a less expensive home.

(a) For example, in zone 3, the proposed standard specifies the maximum Uvalue as 0.096 . Instead the rule could specify in detail a home built with R-22 insulation in the ceiling with the insulation covering the bottom chord (framing members) in the ceiling, R-13 in the walls with framing $16 \mathrm{in}$. on center, and $R-19$ in the floor with the insulation placed between the floor joists (framing members), etc. 


\section{Alternative: Provide Information and a Mortgage Program for Investment in Efficiency}

One alternative would be for HUD to provide information on the energy costs to buyers of manufactured homes. The information might be provided as a required label on the home giving its projected energy use. The label might also include a description of the cost and energy impact of alternative levels of energy efficiency available in that or similar homes. To be most effective, the program should probably be integrated into an energy-efficient mortgage program that lets the buyer qualify for higher loan amounts as investments in energy efficiency.

Unfortunately the only portion of this proposal that has been tested, the energy-efficient mortgage program, has been mostly ineffective. of the people eligible to qualify for energy-efficient mortgages, only 1 in 3,000 to 4,000 has used the programs. (a)

Alternative: Make No Changes

HUD could maintain its existing standard. The major problems with this alternative were those outlined in the market failure section. It is difficult for consumers to monitor and evaluate efficiency options. The evidence from the pre-regulated market is that consumers will considerably under-invest in energy efficiency. Consumers are given incorrect price signals in the residential energy market because energy is imperfectly priced in this regulated market. Finally, there are large social benefits (the environmental externalities) in reducing the energy consumption in new manufactured homes.

\section{Alternatives Rejected}

Given the clear intent of Congress, the alternatives listed above were rejected as a means of satisfying the statutory requirements placed on HUD (HCDA 1987; CRH 1987; CRS 1987).

(a) Personal communication with Paul Hendrickson, Pacific Northwest Laboratory. 


\section{REFERENCES}

Congressional Record - House (CRH), November 6, 1987, H9727.

Congressional Record - Senate (CRS), December 21, 1987, \$18610.

Energy Information Administration (EIA). 1989. Housing Characteristics 1987. DOE/EIA-0314(87), U.S. Department of Energy, Washington, D.C.

Housing and Community Development Act (HCDA) of 1987. Public Law 100-242, Section 569 .

Judkoff, R., R. DeSoto, E. Hancock. 1990. "CMFERT: Training and Testing of Mobile Home Retrofits." Home Energy, January 1990, page 23.

Northwest Power planning Council (NPPC). Northwest Energy News. May/June 1991. "Frustration in the Factory Built Home Industry." Page 31. Portland Oregon.

U.S. Department of Housing and Urban Development and U.S. Department of Commerce. 1989. Characteristics of New Housing: 1988. C25-88-13, U.S. Oepartment of Commerce, Washington, D.C. 


\section{APPENDIX H}

THE VALUE OF ENVIRONMENTAL EXTERNALITIES 
THE VALUE OF ENVIRONMENTAL EXTERNALITIES

The Housing and Community Development Act of 1987 (HCDA 1987), which required the revision of HUD's themal standard, prescribed that the standard should be revised based on "costs to the manufactured home owner" (CRH 1987). However, the impact of the revised standard on society as a whole will include effects external to the market, effects that are not reflected in the prices seen by the consumer. Probably the largest of such "externalities" are the environmental impacts. From the social standpoint, a true quantification of costs and benefits of the proposed revision of the standard should include the costs to society imposed by the use of resources. Although difficult to value, the environmental externalities in energy generation and use can be large. To ignore these environmental costs is to value them at zero. This appendix estimates the magnitude of the environmental externalities.

The value of environmental externalities is difficult to quantify. This appendix only estimates their value. The estimates used here are based on two sources that place a value on externalities based on the damage caused by a pollutant or the cost to control a pollutant. The most comprehensive source for environmental externalities is the study reported in "Environmental Costs of Electricity" done at the Pace University Center for Environmental Studies (0ttinger 1990, referred to later as the PACE study). The PACE study summarized other work in this area and developed estimates of the environmental impacts and costs of using fuel to generate electricity.

The other source of values used here is the Bonneville Power Administration (BPA). BPA produces guidelines for assigning costs to environmental externalities. BPA uses these guidelines for evaluating power generation and conservation options. (a) These BPA guidelines can be used to produce externality costs by generic type of electricity generation (e.g., coal, natural gas) by applying the BPA defaults for emissions and costs. In some cases

(a) The values in this report are based on the May 15, 1991 environmental costs and benefits package sent to potential bidders in the BPA's Competitive Bidding Program. 
there are no BPA guidelines so this report supplemented the BPA values with PACE values. (a)

There are several significant differences between the PACE and BPA values. (b) The PACE study values are more broadly based than the BPA values. PACE values the impact of $\mathrm{CO}_{2}$, while BPA has taken the position that there is a lack of scientific consensus on the value of $\mathrm{CO}_{2}$ and effectively sets the cost of $\mathrm{CO}_{2}$ emissions at zero. (c) PACE sometimes includes a range of technologies, from which this report tried to select a value representative of existing generation capacity. The BPA values are for new generation capacity. PACE is broader in scope.

It is interesting to note that BPA and this proposed HUD standard differ in their use of the externality values. As was required by statute, the HUD proposal was generated considering only the costs and benefits from the consumer's perspective. In contrast, BPA actually incorporates the externalities into their decision making as if the externalities were market costs.

It is important to point out that the value of the environmental exter. nalities assumed here will be conservative for several reasons. First, both studies excluded front-end costs like mining, oil drilling, and fuel processing (PACE, p. 16). Non-environmental externalities, like balance-of-payments impacts and national defense costs, were also excluded. Both studies excluded costs for externalities where they could not identify sources quantifying the costs, such as the air-pollution generated damage to the infrastructure and public facilities, and the air-pollution damage to artistic or historical properties. The inability to determine a cost was the BPA rationale for excluding $\mathrm{CO}_{2}$ as a valued externality. Finally, this report uses the exter-

(a) BPA does not give values for oil-fired generation emissions, an oil heat rate or any values for nuclear generation.

(b) The purpose of the PACE study was to survey work done on quantifying environmental externalities of electrical generation. Most of the work done by, sponsored by, or associated with BPA is included in the PACE study. There are at least 12 key references to values generated by/for BPA in the work done by ECO, Mendelsohn, and BPA (PACE Pp. 179, 209, $228,276)$. The PACE study also includes a broader scope; for example, PACE includes externalities for nuclear generation. BPA does not.

(c) BPA does quantify $\mathrm{CO}_{2}$ as a criteria for ranking options; it just does not assign a value to $\mathrm{CO}_{2}$. 
nalities values for burning specific fossil fuels to make electricity to quantify the impacts of burning the same fuels to heat homes. (a) Because fuel used in heating a home probably will be burned under less controlled conditions than that used in a large utility plant, the pollutant output and the resulting environmental externalities would likely be equal or higher than those for the same amount of fuel used as input to an electrical utility. (b)

The PACE environmental externality cost for electricity was based on the information in Table H.1. Column 1, which is used to weight the relative contributions of the fuel sources, is the percentage of all electricity that comes from each fuel source (EIA 1990). Column 2 identifies the fuel source. Column 3 is the estimated cost of the externality (cents/kwh). The final column gives the source of the cost figure.

\section{IABLE H.1. PACE Electricity Externalities}

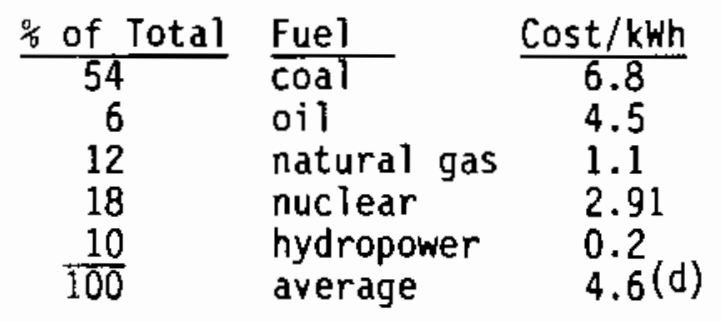

Reference

PACE, p. 351, "existing boiler"

PACE, p. 357, "\#6 0il, 1\% sulfur"

PACE, p. 362, "combined cycle"

PACE, p. 390, "starting point est."

$B P A$ land value for hydropower $(c)$

(a) Counting both air conditioning (which is all electric) and heating, about one-third of the heating and air conditioning energy used in manufactured homes nationwide is electricity. The rest of the heating is provided by fossil fuels.

(b) This does not imply that all homes should heat with electricity. The only implication is that a fossil-fuel burner used by an electrical utility to generate electricity is more controlled and optimized, and, therefore, is probably less polluting per unit of fuel consumed than the average fossil fuel-burner (heater) at a home.

(c) Because the PACE study did not suggest a value for hydropower impact, the $B P A$ value for the land used by a hydropower facility was used in this analysis. The PACE study did contain a BPA case study of the "Sultan hydropower facility," which listed the value for hydropower as 11.5 cents/kwh (PACE, p. 412). However, the PACE study did not generalize this value to all hydroprojects.

(d) On average, $20 \%$ of this value is for $\mathrm{CO}_{2}$. 
Determining the BPA externalities was more complex. BPA does not supply generic externalities; however, it does give default assumptions by which these externalities can be calculated (Tables H.2 and H.3). The externalities in Table H.4 were produced with the BPA guidelines and values as defined below. The general formula is

$$
\begin{aligned}
\text { Environmental Cost }(\$ / \mathrm{kWh})= & \text { Heat_Rate } x \text { Emission_Rate } \mathrm{x} \\
& \text { Pollutant_Externality }+ \\
& \text { Land_\&_Water_Externality }
\end{aligned}
$$

BPA default values for each of these qualities are shown below. Values

\begin{tabular}{|c|c|c|c|c|c|}
\hline \multirow[b]{2}{*}{ Fuel } & \multirow{2}{*}{$\begin{array}{c}\text { Heat } \\
\text { Rate, } \\
\text { Btu/kwh } \\
\end{array}$} & \multirow{2}{*}{$\begin{array}{l}\text { Land and } \\
\text { Water Use, } \\
\text { cent/kWh }\end{array}$} & \multicolumn{2}{|c|}{ Emission Rates } & \multirow{2}{*}{$\frac{\text { lb/MMBtu }}{\text { Particulates }}$} \\
\hline & & & $\mathrm{NO}^{2} \mathrm{x}_{-}$ & $\mathrm{SO}_{2}$ & \\
\hline Natural gas & 8800 & 0.1 & 0.174 & 0.001 & 0.001 \\
\hline Coal & 10856 & 0.2 & 0.5 & 0.6 & 0.03 \\
\hline $0 i 1$ & 10400 & 0.1 & $0.287 \mathrm{P}$ & $1.08 \mathrm{P}$ & $0.09 \mathrm{P}$ \\
\hline
\end{tabular}
with a "P" after them are from the PACE study.

\section{TABLE H.2. BPA Fuel Specific Parameters}

TABLE H.3. BPA Pollutant Externality (\$/1b)

$\begin{array}{ll}\text { Pollutant } & \frac{\operatorname{Cost}}{0.4421} \\ \mathrm{NO}_{\mathrm{x}} & (\mathrm{a}) \\ \mathrm{SO}_{2} & 0.75 \\ \text { Particulates } & 0.7698\end{array}$

(a) BPA gives $\mathrm{NO}_{\mathrm{X}}$ and particulate costs separately for "east" and "west" of the Cascade Mountains in the BPA territory. These values differ because of the population density. The higher "west" values were used here because the western side of the BPA territory probably more closely reflects the national-average population density. 
TABLE H.4. BPA Externality Cost by Pollutant (cents/kwh)

\begin{tabular}{|c|c|c|c|}
\hline Fuel & NOX $x_{-}$ & $\mathrm{SO}_{2}$ & Particulates \\
\hline Natural gas & 0.068 & 0.001 & 0.001 \\
\hline Coal & 0.240 & 0.489 & 0.025 \\
\hline $0 i 1$ & 0.132 & 0.842 & 0.072 \\
\hline
\end{tabular}

The externality cost for electricity by fuel source is 1 isted in Table H.5 and produces an overall externality for electricity (Table H.6). In Table H.6, column 1 is the percentage of all electricity that comes from each fuel source. Column 2 identifies the fuel source. Column 3 is the estimated cost of the externality using BPA assumptions.

BPA's environmental externality for electricity, about $1.1 \mathrm{cent} / \mathrm{k}$ wh, is substantially less than the PACE value, about 4.6 cents $/ \mathrm{kWh}$. A major difference between PACE and $B P A$ is in the treatment of $\mathrm{CO}_{2}$. Some of the

\section{TABLE H.5. Total BPA Electricity Externality (cents/kwh)}

Fuel Source

Natural gas (a)

Coal (b)

$0 i^{(c)}$

Nuclear (d)

Hydropower (e)
Externality

Cost

0.17

0.95

1.15

2.91

0.2

(a) Natural gas values are for a combined-cycle combustion turbine.

(b) Coal values are for pulverized coal.

(c) 0 il values were generated with PACE heat rates

(page 357, "\#6 0il, 1\% sulfur), PACE emission

rates (page 357), BPA externalities by pollutant, and $B P A$ land values.

d) BPA does not refer to nuclear power; therefore, the PACE study value of 2.91 cents/kwh was assumed.

(e) BPA guidelines include only land use externality costs for hydropower, which are used here. 
TABLE H.6. Weighted Average Environmental Externality Based on BPA Values

\begin{tabular}{c}
$\%$ of Tota \\
\hline 54 \\
6 \\
12 \\
18 \\
$\frac{10}{100 \%}$
\end{tabular}

\begin{tabular}{lc} 
Fuel Source & Cost $/ \mathrm{kWh}$ \\
\hline coal & 0.95 \\
oil & 1.15 \\
natural gas & 0.17 \\
nuclear & 2.91 \\
hydropower & 0.2 \\
average & 1.1
\end{tabular}

apparent differences between the two studies may result from the author's selection of specific values from the PACE study, as PACE often gave several options.

Table H.7 shows the BPA and PACE estimates of the environmental costs associated with each energy source. The lower numbers are the BPA values; the higher numbers are the PACE values. The last column is the approximate increase in the consumer's energy price if the environmental externalities were added to the market price of fuel seen by the consumer. Note that the environmental impacts of the energy consumption can be a large fraction of the price of energy.

IABLE H.7. Estimated Environmental Costs from Energy Generation and Use

$\frac{\text { Fuel }}{\text { Electricity }}$

Natura1 gas/LPG ${ }^{(b)}$

Cost and Unit Approx $\%$ of Consumer Price
$\$ 0.01$ to $0.045 / \mathrm{kWh}$
15 to $70 \%$
$\$ 0.12$ to $0.50 / \mathrm{gal}$
20 to $70 \%$
$\$ 0.016$ to $0.12 /$ therm
0 to $15 \%$

(a) Externality cost for oil when used as a home heating fuel was converted from kWh to gallons based on a heat rate of $10,400 \mathrm{Btu} / \mathrm{kwh}$ (PACE page 357), $52 \mathrm{gal} / \mathrm{barrel}$, and 5,825,000 Btu/barrel (EIA 1989)

(b) Externality cost for natural gas when used as a home heating fuel was converted from the value for use in electrical generation from $\mathrm{kWh}$ to therms based on a heat rate of $10,400 \mathrm{Btu} / \mathrm{kWh}$ (PACE page 362), and $100,000 \mathrm{Btu} /$ therm.

To apply these values to the energy used by manufactured homes, it was useful to develop a single value that represented the average increase in retail costs to include externalities. It is estimated that manufactured 
home energy use is one-third electricity, three-fifths natural gas/LPG, and the balance oil. This yields a weighted average of increase from residential prices seen by the consumer of about $8 \%$ for the BPA values and about $38 \%$ for PACE values.

Based on the discussion in the first part of this appendix, it is the author's opinion that the PACE-based values developed here more closely approximate the environmental externalities of energy use than do the BPA values developed here. The most notable differences between the PACE and BPA sources were the greater scope of the PACE study and the assignment of a value to $\mathrm{CO}_{2}$ in the PACE study. In addition, the tendency for both studies to underestimate the value of the environinental externalities by not including costs for several types of impacts suggests using the higher PACE values. Based on an estimate of the energy use in current-practice homes, using both the PACE and externalities; the present value of the environmental externalities of the revised thermal standard is estimated to be $\$ 50$ to $\$ 200(a)$ million per year $(b)$, with the higher estimate being preferred by the authors.

(a) This is about $\$ 160$ million without $\mathrm{CO}_{2}$. About $\$ 40 \mathrm{million}$ of the $\$ 200$ million is for $\mathrm{CO}_{2}$. The $\$ 50$ million goes not include any cost for $\mathrm{CO}_{2}$.

(b) Based on a production of about 200,000 homes per year. 


\section{$\underline{\text { REFERENCES }}$}

Congressional Record - House (CRH), November 6, 1987, H9727.

Housing and Community Development Act (HCDA) of 1987. Public Law 100-242, Section 569 .

Energy Information Administration. 1989. State Energy Price and Expenditure Report 1987. DOE/EIA-0376(87), U.S. Department of Energy, Washington, D.C.

Energy Information Administration. 1990. Annual Energy Outlook: Long-Term Projections. DOE/EIA-0383(90), U.S. Department of Energy, Washington, D.C.

Ottinger, R. L., D. R. Wooley, N. A. Robinson, D. R. Hodas, S. E. Babb. 1990. "Environmental Costs of Electricity", Pace University Center for Environmental Studies (PACE), White Plains, New York. 
APPENDIX I

EXAMPLES OF COSTS AND BENEFITS 
APPENDIX I

\section{EXAMPLES OF COSTS AND BENEFITS}

This appendix looks at costs and benefits from two perspectives and gives examples of cost and benefit calculations. The appendix compares the social (i.e., national benefit) and consumer's perspective, illustrates the trade-off between ECM costs and energy savings using four homes with a large variation in U-values, and shows the annual stream of costs and benefits for the four homes from both perspectives. The values in this appendix are for illustration only; they were not used directly in development of the revised standard. (a)

\section{CALCULATION OF COSTS AND BENEFITS FROM THE SOCIAL PERSPECTIVE}

This section compares the calculation of costs and benefits from the social perspective (as specified for a regulatory impact analysis) to the calculation from the consumer's perspective. These two perspectives are applied in the following section.

The Housing and Community Development Act of 1987 (HCDA 1987), which required the revision of HUD's thermal standards, sets requirements that affect the methodology used in the revision. The statutory requirements prescribed an optimization method chosen to "result in the lowest possible total cost taking into consideration down payment, financing, construction, and energy costs" (CRH 1987) over "the effective physical life of the structure" (CRS 1987) using "costs to the manufactured homeowner" (CRH 1987). From this perspective, the consumer's (the series of owners) stream of costs and benefits are accounted for in the year they occur.

There are several differences between the consumer's perspective and the social perspectives. From the social perspective, ECM materials are used in the year the home is built; therefore, costs for materials are incurred in the year the home is built. From the consumer's perspective, the ECM costs include some first costs (down payment, points, and fees) and future payments for the

(a) It should be noted that the consumer's perspective, not the social perspective was used to set the proposed revised standard. 
ECMs (the mortgage including its interest), with future payments discounted by the consumer's discount rate. Transfer payments (payments for which no real good or service is received in return) are not included from the social perspective. Therefore, mortgage interest, points, loan fees, and property taxes are not included in the social perspective. Both perspectives accumulate energy savings in the year that they occur, and discount the present value of these savings based on the discount rate. The social perspective can also include impacts external to the market, such as the environmental externalities described in Appendix $\mathrm{H}$.

As described in the previous paragraph, the stream of costs and benefits from the two perspectives differ. The social perspective has a large lumpsum first cost in the first year to purchase the ECMs and a stream of energy saving benefits over time. The consumer's perspective has a moderate cost in the first year (down payment, points, fees), a stream of mortgage payments, a stream of taxes, a stream of potential tax benefits (the deduction for mortgage interest) (a), and a stream of energy savings.

From both perspectives, the benefit of the standard is a reduction in energy use. The social benefit of a reduction in energy consumption is greater than the consumer's benefit, as described in Appendixes $G$ and $H$. Appendix $G$ describes the artificially-low marginal price of the regulated residential energy market that under-values marginal increments in energy use. There was no attempt in this report to quantify this size of the under-valuing of the marginal use of energy. Appendix $H$ describes the environmental externalities associated with the use of energy and places a range of values on those externalities. The environmental externalities are costed and included in the values from the social perspective in this appendix.

(a) The tax deduction for mortgage interest is a potential significant regative cost (a benefit); however, most manufactured home owners do not itemize their income tax deductions. Therefore, no value was assigned to the income tax deduction in generating the revised standard or for examples in this appendix. 


\section{COST AND BENEFITS FOR FOUR HOMES WITH VARYING U-VALUES}

This section illustrates how the costs and benefits vary with the U-value, demonstrating the trade-off between the costs for an investment in energy efficiency and the resulting energy savings. Raleigh, North Carolina was selected for this illustration. North Carolina has a representative intermediate latitude and climate. It also has the second largest state sales of manufactured homes in the country (Florida has the largest state sales).

Four home $U$-values representing a wide range of plausible U-values were chosen for this analysis. The cases selected and their approximate U-values were:

1) $U=0.156$, meets current standard for North Carolina

2) $U=0.123$, intermediate between current standard and revised standard

3) $U=0.096$, meets revised standard for North Carolina

4) $U=0.067$, more restrictive than revised standard.

The homes were presumed to use heating fuels that were a weighted average of the fuels used in the region. (Cooling always utilized electricity.) The range of social costs for fuel was assumed to be between 8 and $38 \%$ above the consumer's retail cost of energy, as developed in Appendix $H$.

Table I.1 sumnarizes the costs for each of the four homes from the consumer's and social perspectives. (The annual values over the home's 33-year lifetime for each type of cost are shown later in Tables I.4 through I.7.) Column 1 of Table I.1 shows the home number corresponding to the above list of four U-values. Note that the total energy cost is shown, rather than savings over a base case. The first five columns of dollar values show the consumer's costs for:

- initial down payment, points, and loan fees

- mortgage payments (including interest) over the 15-year life of the loan

- energy costs

- property tax

- total consumer costs. 
TABLE I.1. Summary of Costs from Consumer's and Social Perspective

\begin{tabular}{|c|c|c|c|c|c|c|c|c|}
\hline \multirow[b]{2}{*}{ Home } & \multicolumn{5}{|c|}{ Consumer's Perspective } & \multicolumn{3}{|c|}{ Social Perspective } \\
\hline & $\begin{array}{l}\text { Down\& } \\
\text { Fees }\end{array}$ & Mortg & Energy & $\begin{array}{l}\text { Prop } \\
\text { Tax } \\
\end{array}$ & $\begin{array}{l}\text { Total } \\
\text { Cost }\end{array}$ & $\begin{array}{l}\text { First } \\
\text { Cost }\end{array}$ & $\begin{array}{c}\text { Energy } \\
\text { Cost }\end{array}$ & $\begin{array}{r}\text { Total } \\
\text { Cost } \\
\end{array}$ \\
\hline 1 & 318 & 1883 & 11025 & 524 & 13750 & 2006 & $11907-15215$ & $13913-17221$ \\
\hline 2 & 391 & 2317 & 9048 & 645 & 12402 & 2469 & $9772-12487$ & $12241-14955$ \\
\hline 3 & 495 & 2906 & 7428 & 817 & 11645 & 3123 & $8022-10250$ & $11145-13373$ \\
\hline 4 & 717 & 4246 & 5935 & 1183 & 12081 & 4524 & $6410-8190$ & $10934-12714$ \\
\hline
\end{tabular}

The next three columns are from the social perspective:

- $E C M$ cost

- energy cost including externality (high value is PACE, low value BPA)

- total social costs.

A1l dollar values are in terms of present value. (a) Remember that the home and its energy consumption do not change when viewed from different perspectives, only the valuation of the costs and benefits changes with the perspective taken.

As the home's U-value goes down (i.e., the home becomes better insulated), ECM costs go up and energy costs go down. In Table I.1, the costs associated with ECMs for the consumer are the down payment, mortgage, and property tax columns. From the social perspective, the ECM cost is the incremental first cost. It is interesting to note that the $\mathrm{ECM}$ costs are slightly higher from the consumer's perspective than from the social perspective. This occurs because the real mortgage rate is slightly above the real discount rate, and because the property tax paid by the consumer is a "transfer payment," which is not included in the computation of the social costs. As noted previously, energy costs are higher from the social perspective because of the inclusion of the environmental externalities.

The important column for evaluating the options from a particular perspective is total costs column. The least cost from the consumer's perspective is the home built to the revised standard (home 3 ). The lowest cost from the

(a) The inflation rate was $4.9 \% /$ year. The discount rate was a nominal $12 \%$ or about $7 \%$ real. 
social perspective is the home with the lowest U-value (home 4). Fron the social perspective, the revised standard (home 3 ) is significantly less costly than the current standard (home 1).

The marginal return on the incremental investments in conservation in the four homes is shown in Table I.2. Table I.2 shows incremental changes in the ECM-related costs and energy costs from both perspectives. Negative values or reductions in costs are shown in parentheses "()".

Table I.2 shows that the step from home 1 to home 2 costs the consumer $\$ 629$ for the new ECMs, but reduces the energy costs $\$ 1,977$; thereby netting the consumer $\$ 1,348$. Similarly the step from home 2 to 3 is a net winner from the consumer's perspective. It is interesting to note that the step from home 1 to 2 reduced the consumer's energy costs more than the step from home 2 to 3 , even though the incremental investment in ECMs was greater in going from home 2 to 3 . From the consumer's perspective, going from home 3 to 4 saves energy, but does not return sufficient savings to pay for the ECM investment. Therefore, the step from 3 to 4 is a poor investment for the consumer. The pattern of decreasing marginal return, with an optimum investment beyond which the ECMs cost more than the energy saved, is characteristic of almost all investments in ECMs.

The home with the lowest U-value (home 4) is still the best buy from a social standpoint, although with BPA externality costs the net change from home 3 (revised standard) to home 4 (significantly tighter than the revised standard) is small.

TABLE 1.2. Incrementa] Changes in ECM and Energy Costs

\begin{tabular}{|c|c|c|c|c|c|c|}
\hline \multirow{2}{*}{$\begin{array}{c}\text { Change } \\
\text { From } \\
\text { Home }\end{array}$} & \multicolumn{3}{|c|}{ Consumer's Perspective } & \multicolumn{3}{|c|}{ Social Perspective } \\
\hline & ECM & Energy & Net Change & ECM & Energy & Net Change \\
\hline 1 to 2 & 629 & (1977) & $(1348)$ & 463 & (2135 to 2728 ) & (1672 to 2265$)$ \\
\hline 2 to 3 & 864 & (1621) & (757) & 654 & (1750 to 2237$)$ & (1096 to 1582$)$ \\
\hline 3 to 4 & 1928 & (1493) & 436 & 1401 & (1612 to 2060$)$ & (211 to 659 ) \\
\hline
\end{tabular}


Table I.3 shows the net consumer's and social benefits from the revised standard. For the consumer, going from a home at the current standard (home 1) to the revised standard (home 3 ) has a substantial net benefit, more than $\$ 2,000$ over the home's lifetime. The same change nets $\$ 2,768$ to $\$ 3,848$ from the social perspective. The net social benefit is greater than the net consumer benefit, which reinforces the fact that the revised standard has substantial social benefits not reflected in the energy prices seen by the consumer.

The overall impact of using the BPA assumptions for environmental impacts instead of the PACE assumptions is one of magnitude, not direction. The BPA externalities give the revised standard much less credit for limiting environmental externalities associated with energy use. As Table I.3 shows, the revision of the standard still retains significant social benefits above and beyond those seen by the consumer.

Tables I.4 through I.7 show the stream of annual costs over the lifetime of the four homes from the consumer's and social perspectives. The first column is the year, year 0 being the purchase date. The initial costs for the consumer (down payment, points, and fees) and the social perspective (ECM first cost) occur only in year 0 . The consumer's mortgage costs are shown in both nominal and real dollars. The mortgage is paid off after year 15, so mortgage costs go to \$0 after that year. The annual total costs are shown in both real and discounted terms. The consumer's energy costs and property tax are shown in real dollars. Note that even though energy costs are escalating at about $1.5 \%$ year, the discounted value of the energy costs is decreasing. The social perspective has only two types of costs; the first cost for the home and the energy costs, which include environmental costs.

TABLE I.3. Present Value Benefit from the Revised Standard in Dollars

Change

From Home

1 to $\frac{\text { Consumer's Perspective }}{\text { ECM Energy Net Change }}$

1493

(3598)

(2105)

$\underline{E C M}$

1117

(3885 to 4965$)$

Social Perspective

$\frac{\text { Energy }}{\text { (3885 to } 4965)} \frac{\text { Net Change }}{\text { (2768 to } 3848)}$


TABLE I.4. Consumer's and Social costs for the Current Standard (Home 1)

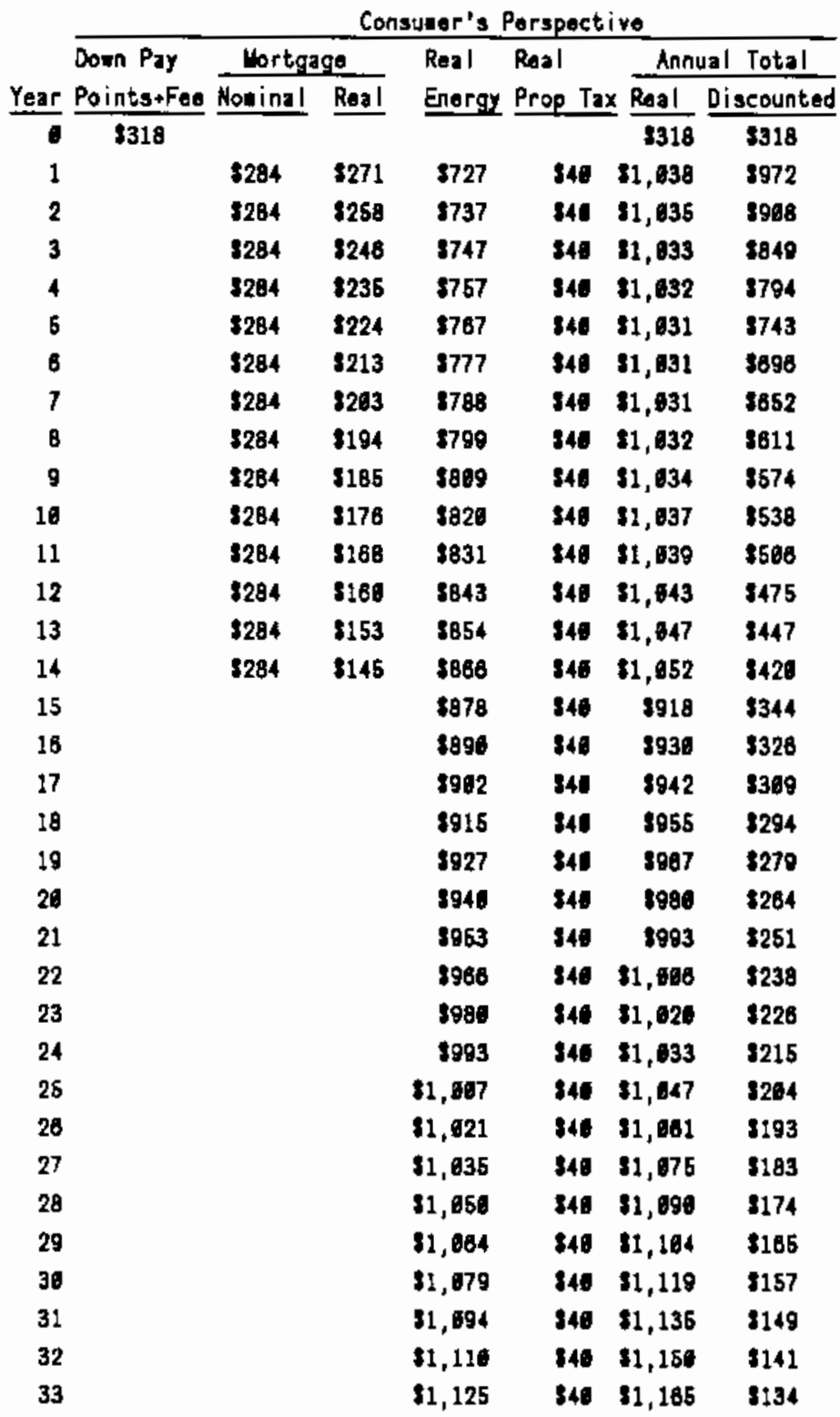

\begin{tabular}{|c|c|c|c|}
\hline \multirow{3}{*}{$\begin{array}{l}\text { First } \\
\text { Cost }\end{array}$} & \multirow{3}{*}{$\begin{array}{c}\text { Social } \\
\text { Real } \\
\text { Energy }\end{array}$} & \multicolumn{2}{|c|}{ Perspectivo } \\
\hline & & \multicolumn{2}{|c|}{ Annual Total } \\
\hline & & Real & Discounted \\
\hline$\$ 2,066$ & & 32,008 & 32,686 \\
\hline & $\$ 1,694$ & $\$ 1,604$ & $\$ 946$ \\
\hline & 31,017 & 81,017 & 8892 \\
\hline & $31, \pm 31$ & 81,031 & 8847 \\
\hline & $\$ 1,644$ & 81,644 & 9884 \\
\hline & 31,058 & 21,658 & $\$ 783$ \\
\hline & 81,073 & 31,073 & 3724 \\
\hline & $\$ 1,687$ & $\$ 1,687$ & 1887 \\
\hline & $\$ 1,102$ & $\$ 1,182$ & 2653 \\
\hline & 32,117 & $\$ 1,117$ & 9619 \\
\hline & $\$ 1,132$ & 31,132 & $\$ 598$ \\
\hline & $\$ 1,147$ & $\$ 1,147$ & 3558 \\
\hline & 31,163 & $\$ 1,183$ & $\$ 536$ \\
\hline & 31,178 & 91,179 & 9503 \\
\hline & $\$ 1,195$ & 31,195 & 3478 \\
\hline & $\$ 1,211$ & 31,211 & 3454 \\
\hline & 81,228 & $\$ 1,228$ & 3431 \\
\hline & 31,245 & 81,245 & 3489 \\
\hline & 11,262 & $\$ 1,282$ & 3388 \\
\hline & 81,279 & $\$ 1,279$ & $\$ 369$ \\
\hline & $\$ 1,297$ & $\$ 1,297$ & 6350 \\
\hline & $\$ 1,3 ! 5$ & 31,315 & 2332 \\
\hline & 81,333 & 81,333 & 8316 \\
\hline & $\$ 1,352$ & 11,352 & 1380 \\
\hline & 31,371 & $\$ 1,371$ & 3285 \\
\hline & $\$ 1,39$ & $\$ 1,39$ & $\$ 270$ \\
\hline & 81,469 & 81,469 & $\$ 257$ \\
\hline & $\$ 1,429$ & $\$ 1,429$ & 3244 \\
\hline & $\$ 1,449$ & $\$ 1,449$ & $\$ 231$ \\
\hline & $\$ 1,468$ & $\$ 1,469$ & 5220 \\
\hline & 31,489 & $\$ 1,489$ & 5269 \\
\hline & $\$ 1,510$ & 31,510 & $\$ 198$ \\
\hline & 81,531 & 31,531 & $\$ 188$ \\
\hline & 81,563 & 31,553 & 3179 \\
\hline
\end{tabular}


TABLE I.5. Consumer's and Social Costs for Home Intermediate Between Current and Revised Standard (Home 2)

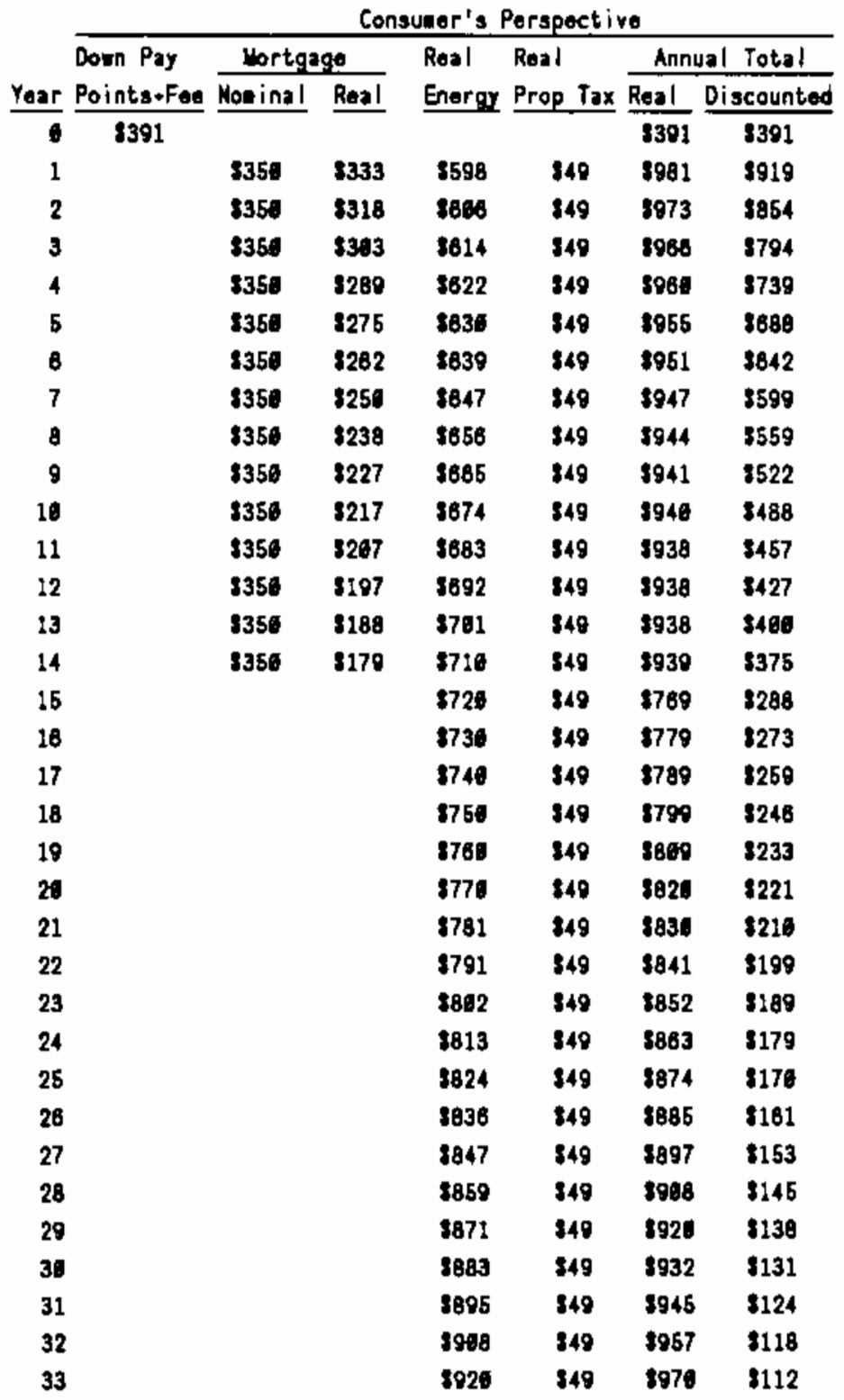

\begin{tabular}{|c|c|c|c|}
\hline \multirow{2}{*}{$\begin{array}{l}\text { First } \\
\text { Cost } \\
\end{array}$} & \multirow{2}{*}{$\begin{array}{l}\text { Roal } \\
\text { Energy }\end{array}$} & \multicolumn{2}{|c|}{ Mnnual Total } \\
\hline & & Real & Discounted \\
\hline 82,469 & & 82,469 & 32,469 \\
\hline & 8826 & 3828 & 8773 \\
\hline & 5038 & 9838 & $\$ 734$ \\
\hline & 8847 & 8847 & 9696 \\
\hline & $\$ 859$ & $\$ 859$ & 3681 \\
\hline & 8870 & $\$ 870$ & 3627 \\
\hline & 8891 & 5881 & 8595 \\
\hline & 3893 & 3893 & 8585 \\
\hline & 3985 & 3905 & 8536 \\
\hline & 3917 & $39: 7$ & 5589 \\
\hline & 3929 & 8929 & 8483 \\
\hline & 3942 & 3942 & 8458 \\
\hline & 3955 & 8955 & 8435 \\
\hline & 3987 & 3987 & 8413 \\
\hline & 8980 & 3980 & $\$ 392$ \\
\hline & 5994 & 3994 & $\$ 372$ \\
\hline & 31,607 & 31,807 & 3353 \\
\hline & $\$ 1,021$ & 11,921 & 9335 \\
\hline & 81,035 & $\$ 1,035$ & 8318 \\
\hline & $\$ 1,049$ & 81,049 & $\$ 392$ \\
\hline & 81,663 & 81,063 & 1287 \\
\hline & 81,077 & 81,077 & $\$ 272$ \\
\hline & $\$ 1,692$ & $\$ 1,692$ & 3259 \\
\hline & 31,107 & 31,107 & 3245 \\
\hline & $\$ 1,122$ & 31,122 & 3233 \\
\hline & 11,138 & $\$ 1,138$ & $\$ 221$ \\
\hline & 31,153 & $\$ 1,153$ & $\$ 210$ \\
\hline & $\$ 1,169$ & 81,189 & 3290 \\
\hline & 81,185 & 31,186 & 3189 \\
\hline & 81,262 & 31,202 & $\$ 186$ \\
\hline & 31,218 & $\$ 1,218$ & $\$ 171$ \\
\hline & 81,235 & $\$ 1,235$ & $\$ 162$ \\
\hline & 81,253 & 31,253 & 8154 \\
\hline & $\$ 1,27$ & 31,276 & 3146 \\
\hline
\end{tabular}


TABLE 1.6. Consumer's and Social Costs for the Revised Standard (Home 3)

\begin{tabular}{|c|c|c|c|c|c|c|c|}
\hline \multirow[b]{3}{*}{ Year } & \multicolumn{7}{|c|}{ Consuner's Perspective } \\
\hline & \multirow{2}{*}{$\begin{array}{l}\text { Down Pay } \\
\text { Points+Foe }\end{array}$} & \multicolumn{2}{|c|}{ Wortgage } & \multirow{2}{*}{$\begin{array}{l}\text { Real } \\
\text { Energy }\end{array}$} & \multirow{2}{*}{$\begin{array}{l}\text { Real } \\
\text { Prop Tax }\end{array}$} & \multicolumn{2}{|c|}{ Annual Total } \\
\hline & & Nooinal & Real & & & Real & Discounted \\
\hline 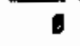 & $\$ 495$ & & & & & $\$ 495$ & 8495 \\
\hline 1 & & $\$ 438$ & $\$ 418$ & $\$ 492$ & 362 & 8972 & 8911 \\
\hline 2 & & $\$ 438$ & 2398 & $\$ 498$ & 382 & 3958 & 8842 \\
\hline 3 & & $\$ 438$ & 3386 & 8605 & 982 & 9947 & 9778 \\
\hline 4 & & 3438 & 8382 & 3511 & 382 & 3936 & 3720 \\
\hline 5 & & 2438 & 3345 & $\$ 518$ & 882 & $\$ 928$ & $\$ 667$ \\
\hline 8 & & $\$ 438$ & 8329 & 8525 & 962 & $\$ 918$ & $\$ 619$ \\
\hline 7 & & $\$ 438$ & 3314 & $\$ 532$ & 382 & 9998 & 3574 \\
\hline 8 & & 9438 & $\$ 299$ & 5539 & 882 & 3990 & 8533 \\
\hline 9 & & 3438 & 3285 & 3546 & $\$ 62$ & 9893 & 3496 \\
\hline 16 & & 8438 & $\$ 272$ & 3553 & $\$ 62$ & 5887 & 3481 \\
\hline 11 & & 8438 & $\$ 259$ & 8580 & 382 & 1882 & 3429 \\
\hline 12 & & 5438 & $\$ 247$ & 8588 & 982 & 8977 & 3400 \\
\hline 13 & & 3436 & 3235 & 8575 & $\$ 82$ & 5873 & 8373 \\
\hline 14 & & 8438 & 3224 & 3583 & 562 & $\$ 870$ & 5348 \\
\hline 18 & & & & 3591 & 582 & $\$ 653$ & 3245 \\
\hline 18 & & & & $\$ 699$ & 882 & 3681 & 1232 \\
\hline 17 & & & & 8697 & 882 & 8869 & $\$ 226$ \\
\hline 18 & & & & 2815 & 362 & 3877 & 5208 \\
\hline 19 & & & & $\$ 623$ & 182 & 9686 & $\$ 198$ \\
\hline 26 & & & & 8631 & 862 & 3894 & 8187 \\
\hline 21 & & & & 8640 & $\$ 62$ & 8792 & $\$ 178$ \\
\hline 22 & & & & 3849 & 362 & 8711 & $\$ 188$ \\
\hline 23 & & & & $\$ 857$ & 382 & 3726 & $\$ 180$ \\
\hline 24 & & & & 5888 & 382 & 8729 & 3151 \\
\hline 25 & & & & 9676 & 882 & 3736 & $8: 44$ \\
\hline 28 & & & & 3685 & 582 & 9747 & $\$ 136$ \\
\hline 27 & & & & 3694 & 382 & $\$ 758$ & $\$ 129$ \\
\hline 28 & & & & 2763 & 362 & 8788 & $\$ 122$ \\
\hline 29 & & & & $\$ 713$ & 962 & 8775 & 8118 \\
\hline 30 & & & & 8723 & 862 & $\$ 795$ & $\$ 110$ \\
\hline 31 & & & & 8733 & 962 & 2795 & $\$ 104$ \\
\hline 32 & & & & 8743 & 362 & 8806 & 599 \\
\hline 33 & & & & $\$ 753$ & 362 & 5815 & 894 \\
\hline
\end{tabular}

\begin{tabular}{|c|c|c|c|}
\hline \multirow{2}{*}{$\begin{array}{r}\text { First } \\
\text { Cost } \\
\end{array}$} & \multirow{2}{*}{$\begin{array}{c}\text { Roal } \\
\text { Energy }\end{array}$} & \multicolumn{2}{|c|}{ Annual Total } \\
\hline & & Real & Discounted \\
\hline 53,123 & & $\overline{33,123}$ & 13,123 \\
\hline & $\$ 826$ & 3826 & 8773 \\
\hline & $\$ 836$ & $\$ 836$ & $\$ 734$ \\
\hline & 8847 & $\$ 847$ & $\$ 696$ \\
\hline & 3859 & $\$ 859$ & 3681 \\
\hline & 3870 & 3870 & $\$ 827$ \\
\hline & $\$ 881$ & 5881 & $\$ 696$ \\
\hline & 3893 & 8893 & 9585 \\
\hline & 3965 & 2905 & 2536 \\
\hline & 3917 & 5917 & 3569 \\
\hline & $\$ 929$ & $\$ 929$ & $\$ 483$ \\
\hline & 3942 & 5942 & $\$ 458$ \\
\hline & 8955 & 3955 & 9435 \\
\hline & 3987 & 5967 & 3413 \\
\hline & 5986 & 1980 & $\$ 382$ \\
\hline & 3994 & 5994 & 3372 \\
\hline & 81,007 & 31,007 & 8353 \\
\hline & $\$ 1,021$ & $\$ 1,021$ & 8335 \\
\hline & $\$ 1,035$ & $\$ 1,035$ & 8318 \\
\hline & 81,049 & 31,049 & $\$ 362$ \\
\hline & 11,063 & 31,063 & 3287 \\
\hline & $\$ 1,077$ & $\$ 1,677$ & 3272 \\
\hline & $\$ 1,892$ & $\$ 1,892$ & 8259 \\
\hline & $\$ 1,107$ & 91,107 & $\$ 245$ \\
\hline & 31,122 & $\$ 1,122$ & 3233 \\
\hline & 31,130 & 31,138 & 8221 \\
\hline & 31,153 & 81,153 & 8210 \\
\hline & 31,169 & $\$ 1,169$ & $\$ 200$ \\
\hline & $\$ 1,185$ & $\$ 1,165$ & $\$ 189$ \\
\hline & $\$ 1,202$ & 31,202 & $\$ 180$ \\
\hline & $\$ 1,218$ & $\$ 1,218$ & $\$ 171$ \\
\hline & 31,235 & $\$ 1,235$ & $\$ 182$ \\
\hline & 31,253 & 81,253 & 3154 \\
\hline & $\$ 1,270$ & $\$ 1,270$ & 3146 \\
\hline
\end{tabular}


TABLE I.7. Consumer's and Social Costs for Home Tighter than Revised Standard (Home 4)

\begin{tabular}{|c|c|c|c|c|c|c|c|c|c|c|c|}
\hline \multirow{3}{*}{\multicolumn{2}{|c|}{$\begin{array}{l}\text { Down Pay } \\
\text { Year Points+Fee }\end{array}$}} & \multicolumn{6}{|c|}{ Consuner's Perspect ive } & \multicolumn{4}{|c|}{ Social Perspective } \\
\hline & & \multicolumn{2}{|c|}{ Hortgage } & \multirow{2}{*}{$\begin{array}{l}\text { Real } \\
\text { Energy }\end{array}$} & \multirow{2}{*}{$\begin{array}{l}\text { Roal } \\
\text { Prop Tax }\end{array}$} & \multicolumn{2}{|c|}{ Annual Total } & \multirow{2}{*}{$\begin{array}{r}\text { First } \\
\text { Cost } \\
\end{array}$} & \multirow{2}{*}{$\begin{array}{c}\text { Real } \\
\text { Energy }\end{array}$} & \multicolumn{2}{|c|}{ Annual Total } \\
\hline & & Nominal & Roal & & & Real & Discounted & & & Rogl & Discounted \\
\hline 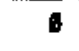 & $\$ 717$ & & & & & $\$ 717$ & $\$ 717$ & 84,524 & & 94,524 & 34,524 \\
\hline 1 & & 8841 & 3611 & $\$ 394$ & 399 & $\$ 1,698$ & 31,026 & & 3544 & 8544 & 9510 \\
\hline 2 & & 8641 & 5682 & 3399 & 890 & 81,072 & $\$ 940$ & & $\$ 551$ & 8551 & $\$ 484$ \\
\hline 3 & & $\$ 841$ & $\$ 655$ & 8485 & 198 & 31,050 & 9863 & & 1558 & 3558 & 8459 \\
\hline 4 & & 5841 & $\$ 529$ & 3410 & 199 & 81,029 & 9792 & & 3585 & 3585 & 8435 \\
\hline 5 & & 3841 & $\$ 604$ & 3415 & 390 & $\$ 1,010$ & 5728 & & 8573 & $\$ 573$ & 3413 \\
\hline 6 & & 3841 & 8481 & 8420 & 891 & 8991 & 5689 & & 9586 & 9580 & 8391 \\
\hline 7 & & 8641 & 8458 & 1426 & 180 & 9974 & 8816 & & 8587 & 9587 & 3371 \\
\hline 8 & & 3841 & 8437 & 5431 & 398 & 9958 & $\$ 568$ & & $\$ 695$ & 3595 & 3352 \\
\hline 9 & & 3641 & 9417 & 8437 & 396 & $\$ 944$ & 2523 & & $\$ 892$ & 9682 & 8334 \\
\hline 10 & & 8641 & 8397 & $\$ 442$ & 990 & 3930 & $\$ 483$ & & 8610 & 8810 & $\$ 317$ \\
\hline 11 & & 8641 & 8378 & 8448 & 890 & 3917 & 3448 & & 8818 & 8818 & $\$ 301$ \\
\hline 12 & & 8641 & $\$ 361$ & 8454 & 390 & 8905 & 5412 & & $\$ 828$ & 8826 & $\$ 285$ \\
\hline 13 & & 8641 & 8344 & 3469 & 399 & 5894 & 3382 & & 5834 & 5834 & $\$ 271$ \\
\hline 14 & & 3841 & 3328 & 3468 & 899 & 5884 & 8353 & & 3843 & $\$ 643$ & 9257 \\
\hline 15 & & & & $\$ 472$ & 390 & 8562 & $\$ 210$ & & 8851 & 8651 & 1244 \\
\hline 18 & & & & 8478 & 590 & 8588 & $\$ 199$ & & $\$ 859$ & 8659 & $\$ 231$ \\
\hline 17 & & & & $\$ 484$ & 390 & 9675 & 3189 & & 1888 & 1888 & 3219 \\
\hline 18 & & & & 8498 & 390 & $\$ 581$ & 8179 & & $\$ 877$ & 1877 & 2208 \\
\hline 19 & & & & 8497 & 894 & 8587 & 8189 & & 1888 & 9888 & $\$ 198$ \\
\hline 20 & & & & 8683 & 890 & 8594 & $\$ 180$ & & $\$ 895$ & $\$ 695$ & $\$ 188$ \\
\hline 21 & & & & 3810 & 590 & 1801 & 8152 & & 3704 & 5704 & $\$ 178$ \\
\hline 22 & & & & 8517 & 590 & 1807 & 8144 & & $\$ 713$ & 3713 & 1160 \\
\hline 23 & & & & 8524 & 990 & 8814 & 8138 & & $\$ 723$ & 5723 & 3186 \\
\hline 24 & & & & $\$ 631$ & 590 & 8821 & $\$ 129$ & & 3732 & $\$ 732$ & 3152 \\
\hline 25 & & & & 8538 & 990 & 2828 & $\$ 122$ & & $\$ 742$ & $\$ 742$ & 3144 \\
\hline 28 & & & & 3545 & 590 & 3836 & 3118 & & 8752 & $\$ 752$ & 3137 \\
\hline 27 & & & & 8552 & 890 & 8643 & 8110 & & $\$ 762$ & $\$ 762$ & 3130 \\
\hline 28 & & & & 8580 & 890 & 3850 & 3164 & & $\$ 772$ & $\$ 772$ & $\$ 123$ \\
\hline 29 & & & & $\$ 587$ & 590 & 8658 & 398 & & 8783 & 8783 & 8117 \\
\hline 38 & & & & 3576 & 590 & $\$ 885$ & $\$ 93$ & & 8793 & $\$ 793$ & $\$ 111$ \\
\hline 31 & & & & $\$ 503$ & 890 & 8873 & 888 & & 3804 & 5894 & $\$ 108$ \\
\hline 32 & & & & 8591 & 990 & 5881 & 884 & & 3815 & 3815 & 5100 \\
\hline 33 & & & & 8599 & 999 & 5889 & $\$ 79$ & & $\$ 828$ & 3826 & 595 \\
\hline
\end{tabular}




\section{REFERENCES}

Congressional Record - House (CRH), November 6, 1987, H9727.

Congressional Record - Senate (CRS), December 21, 1987, S18610.

Housing and Community Development Act (HCDA) of 1987. Public Law 100-242, Section 569 . 
APPENDIX J

TEXT OF CONGRESSIONAL REQUIREMENTS 


\section{APPENDIX $J$}

\section{TEXT OF CONGRESSIONAL REQUIREMENTS}

This appendix reproduces the text of the Congressional requirements for the revised HUD standard. The Housing and Community Development Act of 1987 (HCDA) and the accompanying conference reports (CRH 1987; CRS 1987) defined the general method that was used to produce the proposed revised thermal standards for HUD's Manufactured Home Construction and Safety Standards (MHCSS) (24 CFR 3280).

From the Housing and Community Development Act of 1987 (HCDA):

Sec. 569. MANUFACTURED HOUSING CONSTRUCTION AND SAFETY STANDARDS.

Section 604 of the National Manufactured Housing Construction and Safety Standards Act of 1974 is amended by adding at the end the following new subsection:

(i) (1) The Federal manufactured home construction and safety standards established by the Secretary under this section shall include preemptive energy conservation standards in accordance with this subsection.

(2) The energy conservation standards established under this subsection shall be cost-effective energy conservation performance standards designed to ensure the lowest total of construction and operating costs.

(3) The energy conservation standards established under this subsection shall take into consideration the design and factory construction techniques of manufactured homes and shall provide for alternative practices that result in net estimated energy consumption equal to or less than the specified standards.

From the Congressional Record of the House (CRH):

\section{Manufactured Homes Energy Conservation Standards}

The House amendment contained a provision not included in the Senate bill that would require HUD to establish energy conservation standards for manufactured homes that are equivalent in energy performance to those required for FHA-insured single family homes. The conference report includes a substitute provision that would require HUD to issue preemptive cost-effective energy conservation standards that: 1) are designed to ensure the lowest total of construction and operating costs; 2) take into consideration the design and factory construction techniques of manufactured homes; and 3) provide for alternative practices that result in net estimated energy consumption equal or less than the specified standard. 
The conferees agreed that the present energy conservation standards applicable to manufactured homes are inadequate and the Department's efforts to delegate these standards to a multitude of conflicting State energy codes defeats the requirement of a preemptive national code for manufactured housing. The conferees also recognize that the application of a standard equivalent in energy performance to the FHA Minimum Property Standards in some southern areas of the country would result in decreasing the energy efficiency of these homes, not creating the most cost-effective energy standards as the agreement would require.

The provision would require the Department to develop a standard that results in the lowest total costs to manufactured homeowners. Such a goal can be achieved by establishing a standard that assures the combination of construction costs and estimated value of energy saved through the operation of the energy-efficient home over its estimated useful life will result in the lowest possible total cost taking into consideration down payment, financing, construction and energy costs to the manufactured homeowner.

Since the manufactured home standard generally is a performance standard, the energy conservation standard will also be a performance standard and it is expected that HUD will establish separate maximum transmission heat loss coefficients for the overall envelope area for single-wide and double-wide manufactured homes in a number of climatic zones.

In developing these standards, HUD should assume reasonable levels of air infitration, heating and cooling equipment efficiencies and solar heat gain through glazing and should assure minimum effect on the overall costs of home ownership. In addition, any design claiming, through generally accepted engineering practices, energy performance equal or better than the specified performance standard should be allowed to benefit from improvements to those components.

It is expected that the Department will rely on currently available research in order to develop cost-effective energy standards and make them effective within one year from enactment."

\section{From the Congressional Record of the Senate (CRS):}

Mr. ADAMS. Mr. President, I rise to congratulate the subcommittee chairman, Mr. CRANSTON, for his distinguished leadership on this important piece of legislation and to offer my special thanks for his efforts to deal with the provisions that would improve the energy efficiency of manufactured housing built in this country.

This is an extremely important issue in the Pacific Northwest where these structures account for approximately 30 to 40 percent of new electricity heated homes built in this region. The standards that we 
expect to come out of this legislation should save my region alone approximately $\$ 500$ million over the next 20 years.

I want to take this opportunity to clarify my support of the important features related to Section 569 of S. 825 .

It is my understanding that the Department of Housing and Urban Development will conduct a life cycle cost analysis, taking into consideration the cost of energy savings from those measures over the effective physical life of the structure and that this important analysis is to be completed within 1 year of this legislation.

Mr CRANSTON. I thank the Senator from Washington for his support and assistance on this important legislation. The Senator is correct that the purpose of this Section 569 of S. 825 is to require the Department of Housing and Urban Development to complete a life cycle cost analysis to develop national standards for the energy efficiency of new manufactured housing. This important legislation is to be completed in 1 year.

MR. ADAMS. I thank the distinguished subcomittee chaiman from California. This is a very important effort and we need to begin moving as quickly as possible. 


\section{REFERENCES}

Congressional Record - House (CRH), November 6, 1987, H9727.

Congressional Record - Senate (CRS), December 21, 1987, S18610.

Housing and Community Development Act (HCDA) of 1987. Public Law 100-242, Section 569.

24 CFR 3280. 1987. U.S. Department of Housing and Urban Development, "Manufactured Home Construction and Safety Standards." U.S. Code of Federal Regula. tions. 
PNL-7109

UC -350

\section{DISTRIBUTION}

No. of

Copies

OFFSITE

5 U.S. Department of Housing and Urban Development

Policy Research and Development Attn: William Freeborne 451 7th Street SW, Room 8176 Washington, DC 20410

5 U.S. Department of Housing and Urban Development Standards and Products Branch Attn: Donald Fairman 4517 th Street SW, Room 6270 Washington, DC 20410

12 DOE/Office of Scientific and Technical Information

Alabama Electric Cooperative Attn: Steve Thomas

P.0. Box 550

Andatusia, AL 36420

Applied Science and Engineering Attn: Jay McGrew

39 Niblick Lane

Littleton, CO 80123

At lanta Gas and Light

Attn: John 0. (Jack) Sholar P.0. Box 4569

At lanta, GA 30302

Association for Regulatory Reform

Attn: Danny Ghorbani

1331 Pennsylvania Avenue NW

Suite 508

Washington, DC 20004
No. of

Copies

Bonneville Power Administration Residential Programs Branch Attn: Stephen Onisko P.0. Box 3621 - RRRD Portland, OR 97208

Bonneville Power Administration Assessment and Evaluation Branch Attn: Sheila Riewer P.0. Box 3621 - RREB Portland, OR 97208

California Energy Commission Attn: John A. Wi Ison 1516 9th Street Sacramento, CA 95814-5512

Compliance Systems Publications Attn: Earl A. Ferguson 3071 Peachtree Road, N.E. \$222 At lanta, GA 30305

Fleetwood Enterprises, Inc. Attn: Edward Salsbury 3125 Myers Street

Riverside, CA 92523

Farmers Home Administration Attn: Rich Davis 14th and Independence Ave, S.W. washington, DC 20250

State of Florida Office of the Governor Energy office Attn: Dayrl 0'Conner The Capitol

Tallahassee, FL 32399-0001 
PNL-7109

UC -350

State of Florida

Florida Department of Community Affairs

Attn: Rick Dixon

The Capitol

Tallahassee, FL 32399

Foremost Financial Services

Attn: Richard W. Stagman

5800 Foremost Drive, SE

Grand Rapids, MI 49501

Jacksonville Electric Authority

Attn: Philip Wemhoff

P.0. Box 53015

Jacksonville, FL 32201

The Levy Partnership

Attn: M. Emannual Levy

40 East 19th Street

7 th Floor

New York, NY 10003

Manufactured Housing Institute

MHCSS Consensus Committee

Attn: Frank Walter

Suite 511

1745 Jefferson Davis Highway

Arlington, Virginia 22202

Meetings+Plus

David Leichey

P.0. Box 1981

Palm Springs,

CA 92263

Mineral Insulation

Manufacturer's Association

Attn: Steve Braun

1420 King Street

Alexandria, Virginia 22314

Modul ine

Attn: Ron Sparkman

P.0. Box 1106

Chehalis, WA 98532
Monsanto Chemical Company

Attn: Mike E. McKitrick

800 N. Lindbergh, M3G

St. Louis, Missouri 63167

Natural Resources Defense Council

Attn: David Goldstein

25 Kearny Street

San Francisco, CA 94108

Northwest Power Planning

Council

Attn: Thomas L. Eckman

850 SW Broadway, Suite 1100

Portland, OR 97205

Oak Ridge National Laboratory

Attn: Jeff Christian

P.0. Box 2008

0ak Ridge, TN 37831-607D

Owens-Corning Fiberglass

Technical Center

Attn: Merle F. McBride

2790 Columbus Road, Route 16

Grandvilie $\mathrm{OH}$ 43023-1200

Solar Energy Research Institute

Attn: Ron Judkoff

1617 Cole Blvd.

Golden, CO 80401

Steven Winter Associates

Attn: Adrian Tuluca

6100 Empire State Building

New York, NY 10001

U.S. Department of Energy

Office of Codes and Standards

Attn: Jean J. Boulin

Forrestal Building, CE-43

1000 Independence Avenue SW

Washington, DC 20585 
PNL -7109

UC -350

U.S. Department of Energy

Weatherization Assistance Programs

Attn: Mary Fowler

Forrestal Building, CE-232

1000 Independence Avenue SW

Washington, DC 20585

U.S. Department of Energy

Building Services Division

Attn: George James

Forrestal Building, CE-133

1000 Independence Avenue $\mathrm{SW}$

Washington, DC 20585

U.S. Department of Energy

Building Systems Division

Attn: Mike McCabe

Forrestal Building, CE-131

1000 Independence Avenue SW

Washington, DC 20585

U.S. Department of Energy

Building Systems Division

Attn: John Millhone

Forrestal Building, CE-131

1000 Independence Avenue SW

Washington, DC 20585

U.S. Department of Energy

Office of Codes and Standards

Attn: Steve J. Turchen

Forrestal Building, CE-43

1000 Independence Avenue SW

washington, DC 20585

U.S. Department of Energy

Office of Codes and Standards

Attn: Steven Walder

Forrestal Building, CE-43

1000 Independence Avenue SW

Washington, DC 20585
U.S. Department of Housing and Urban Development

Standards and Products Branch

Attn: Victor Ferrante

4517 th Street SW, Room 6270

Washington, DC 20410

U.S. Department of Housing and Urban Development

Division of Manufactured Housing Construction Stds

Attn: Robert Fuller

451 7th Street SW, Room 9156

Washington, DC 20410

U.S. Department of Housing and Urban Development Energy Division

Attn: Robert P. Groberg

4517 th Street SW, Room 7244

Washington, DC 20410

U.S. Department of Housing and Urban Development

Office of Manufactured Housing and Regulatory Functions

Attn: David C. Nimmer

451 7th Street SW, Room 9156

washington, DC 20410

U.S. Department of Housing and Urban Development

Manuf actured Housing Construct and Safety Standards

Attn: Philip Schulte

4517 th Street SW, Room 9156

Washington, DC 20410

U.S. Department of Housing and Urban Development

Office of Policy Research and Development

Attn: James Stimpson

451 7th Street SW, Room 8144

Washington, DC 20410 
PNL-7109

UC-350

U.S. Department of Natural Resources and Conservation Attn: Kathi Montgomery 1520 East 6th Avenue Helena, Montana 59620-2301

U.S. Department of Water Resource

Division of Energy

Attn: Ken Eklund

Statehouse Mail-1301

North Orchard Street

Boise, Idaho 83720

University of Florida

Industrial and Systems

Engineering Department

Attn: Barney L. Capehart

303 Weil Hall

Gainesville, FL 32611

Washington State Energy Office

Attn: Elizabeth Klumpp

809 Legion Way S.E., FA-11

0lympia, WA 98504-1211

Washington State Energy Office

Attn: Michael Lubliner

809 Legion Way S.E., FA-11

Olympia, WA 98504-1211
ONSITE

DOE Richland Field Office

Don R. Segna

24 Pacific Northwest Laboratory

Michael R. Brambley, K5-16

Craig C. Conner (10), K5-16

David R. Conover, BWO

Ronald E. Jarnagin, K5-16

Allen D. Lee, PORTL

Robert G. Lucas, K5-16

Andrew K. Nicholls, BWO

Thomas J. Secrest, K5-20

Z. Todd Taylor, K5-16

Publishing Coordination

Technical Report Files (5) 